\title{
PRMS-IV, the Precipitation-Runoff Modeling System, Version 4
}

Chapter 7 of

Section B, Surface Water

Book 6, Modeling Techniques

Techniques and Methods 6-B7 



\section{PRMS-IV, the Precipitation-Runoff Modeling System, Version 4}

By Steven L. Markstrom, R. Steven Regan, Lauren E. Hay, Roland J. Viger, Richard M. T. Webb, Robert A. Payn, and Jacob H. LaFontaine

Chapter 7 of

Section B, Surface Water

Book 6, Modeling Techniques

Techniques and Methods 6-B7 


\title{
U.S. Department of the Interior SALLY JEWELL, Secretary
}

\section{U.S. Geological Survey Suzette M. Kimball, Acting Director}

\author{
U.S. Geological Survey, Reston, Virginia: 2015
}

For more information on the USGS - the Federal source for science about the Earth, its natural and living resources, natural hazards, and the environment, visit http://www.usgs.gov or call 1-888-ASK-USGS.

For an overview of USGS information products, including maps, imagery, and publications, visit http://www.usgs.gov/pubprod

To order this and other USGS information products, visit http://store.usgs.gov

Any use of trade, firm, or product names is for descriptive purposes only and does not imply endorsement by the U.S. Government.

Although this information product, for the most part, is in the public domain, it also may contain copyrighted materials as noted in the text. Permission to reproduce copyrighted items must be secured from the copyright owner.

Suggested citation:

Markstrom, S.L., Regan, R.S., Hay, L.E., Viger, R.J., Webb, R.M.T., Payn, R.A., and LaFontaine, J.H., 2015, PRMS-IV, the precipitation-runoff modeling system, version 4: U.S. Geological Survey Techniques and Methods, book 6, chap. B7, 158 p., http://dx.doi.org/10.3133/tm6B7. 


\section{Contents}

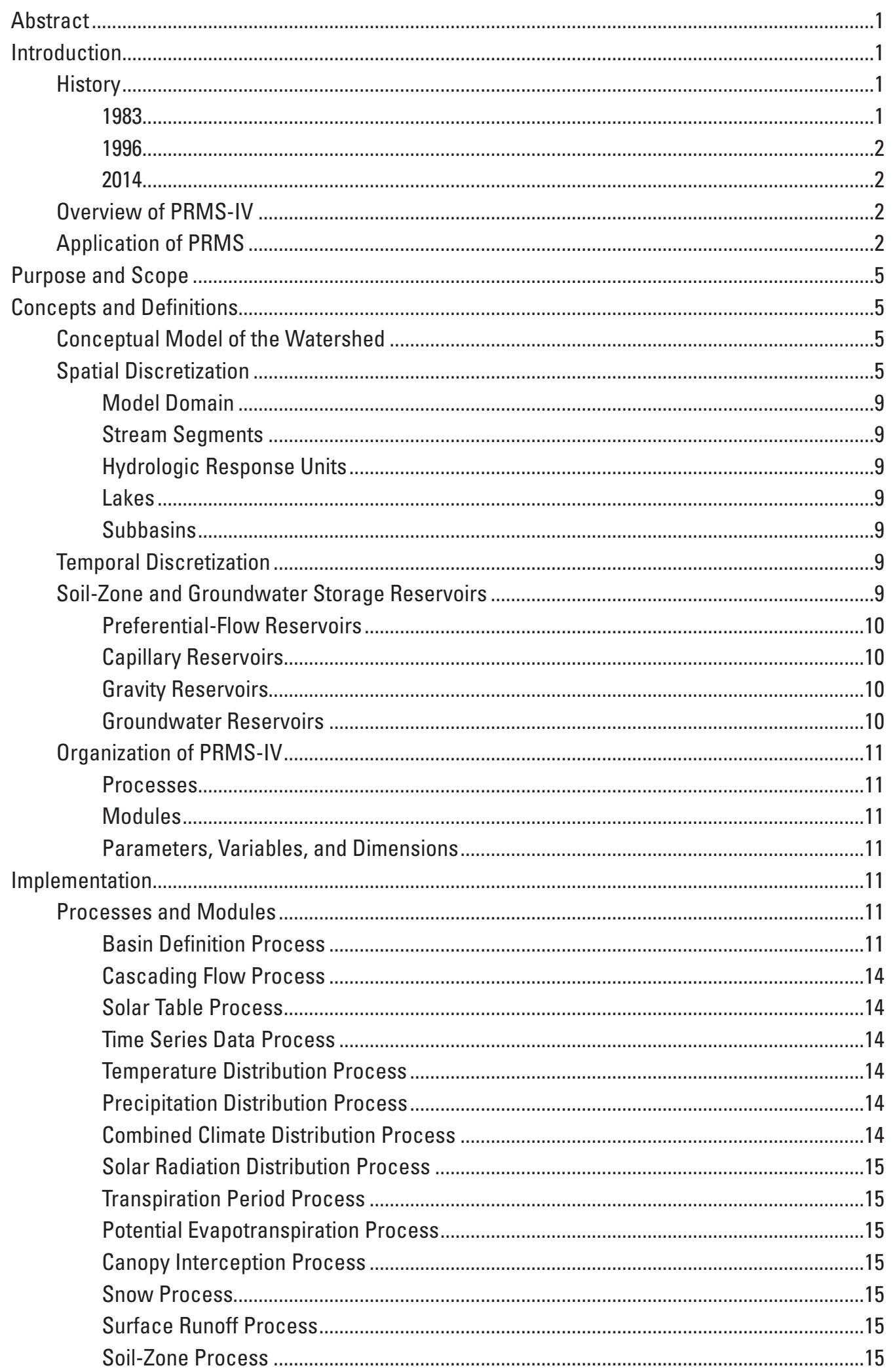




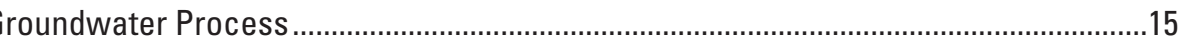

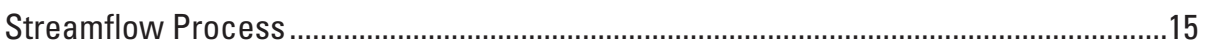

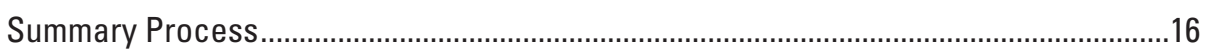

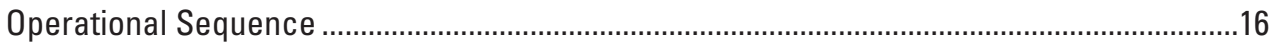

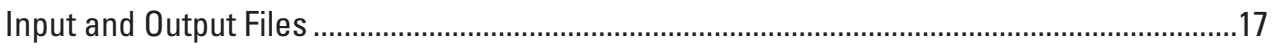

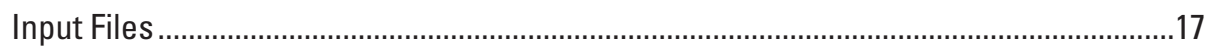

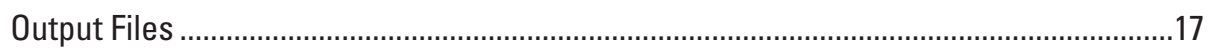

Summary

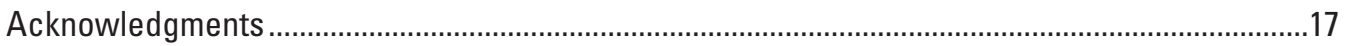

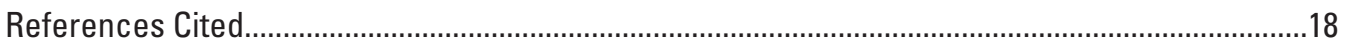

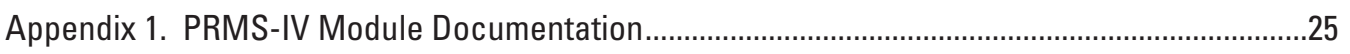

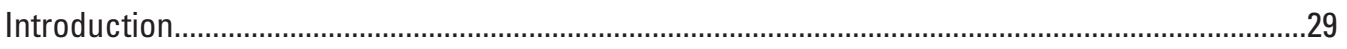

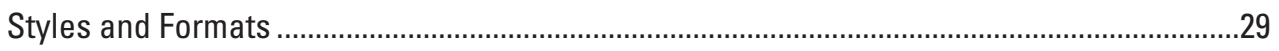

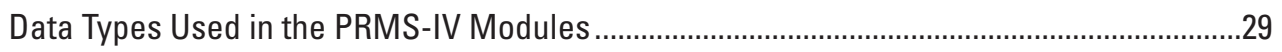

Computation Control Module: call_modules ...............................................................................75

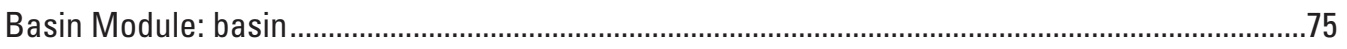

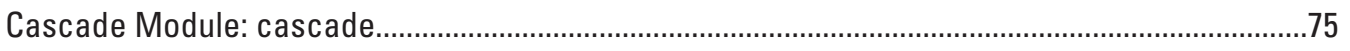

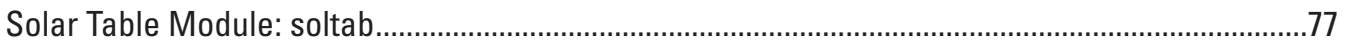

Time-Series Data Module: obs ...........................................................................................

Temperature-Distribution Modules.......................................................................................

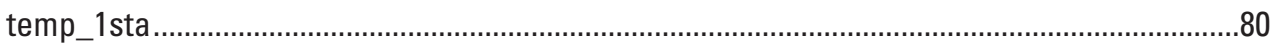

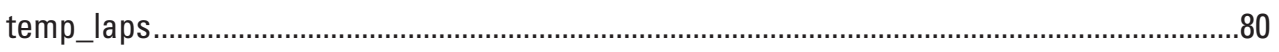

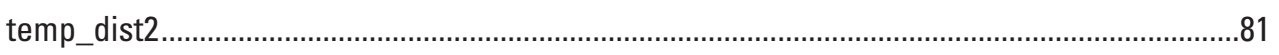

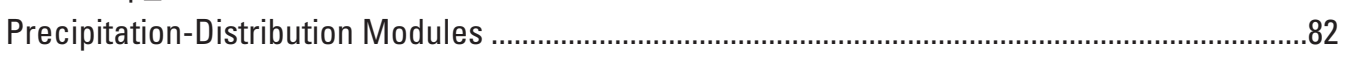

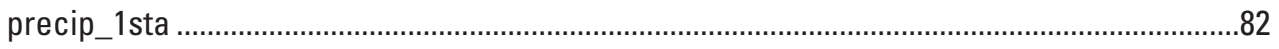

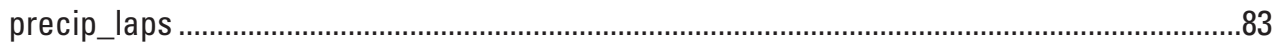

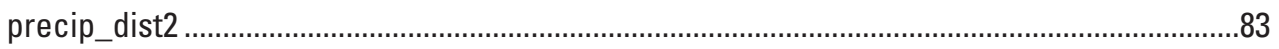

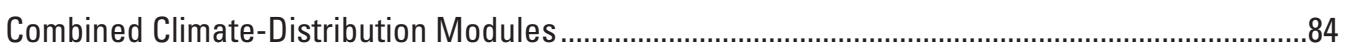

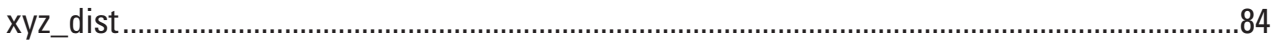

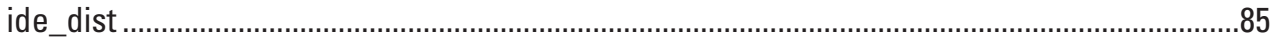

Climate-by-HRU Distribution Module: climate_hru......................................................................

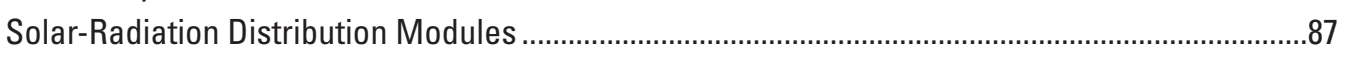

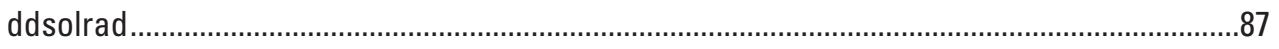

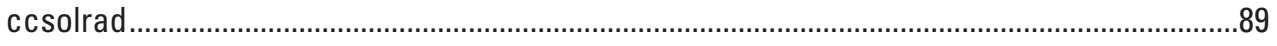

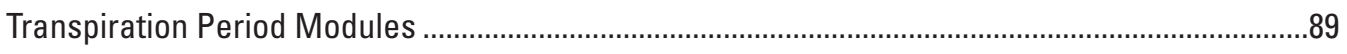

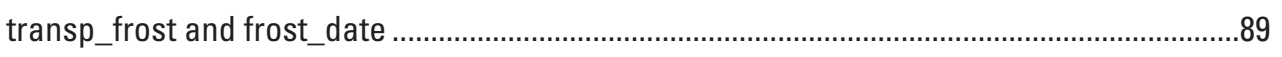

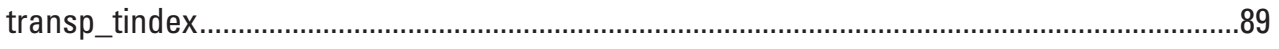

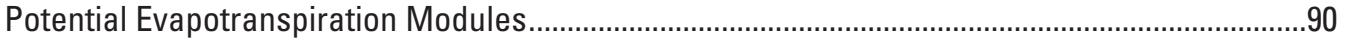

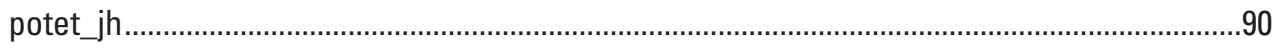

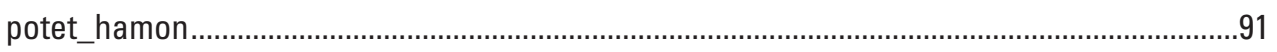

potet_hs

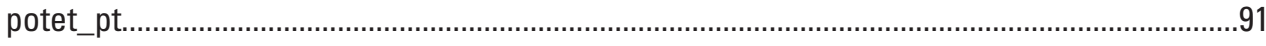

potet_pm

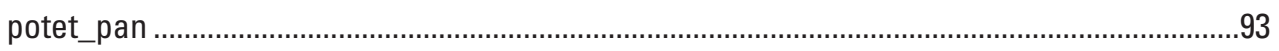

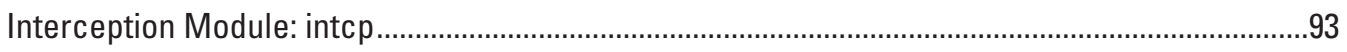

Snow Module: snowcomp .............................................................................................. 


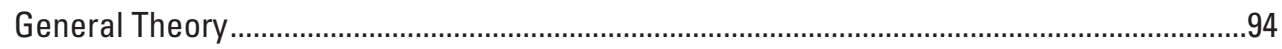

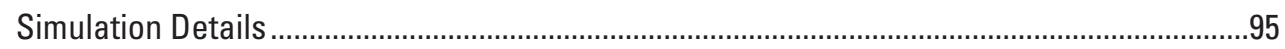

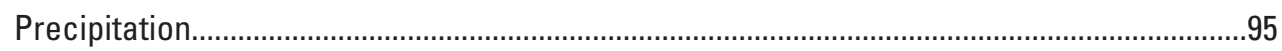

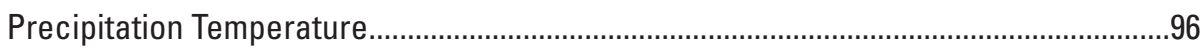

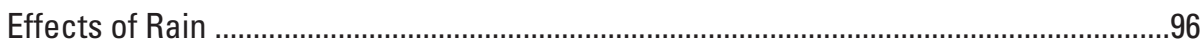

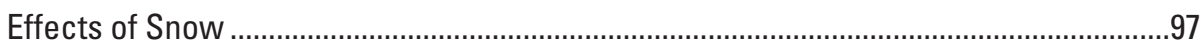

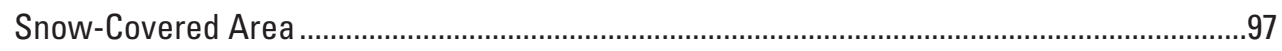

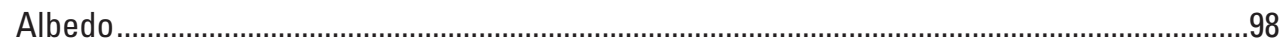

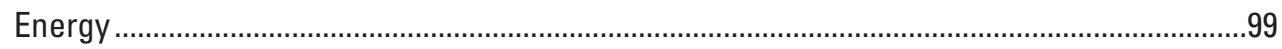

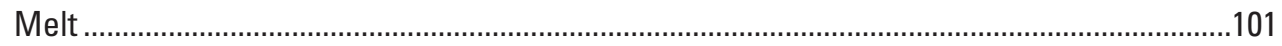

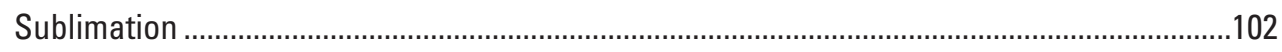

Surface-Runoff Modules: srunoff_smidx and srunoff_carea ..........................................................102

Impervious Storage and Evaporation ....................................................................................102

Pervious Hortonian Surface Runoff and Infiltration................................................................103

Surface-Depression Simulation .......................................................................................... 104

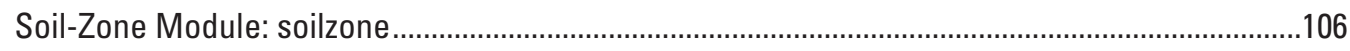

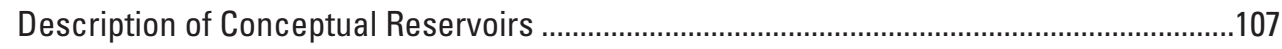

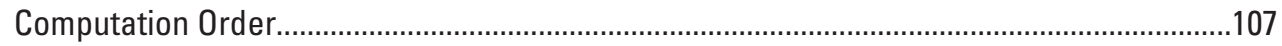

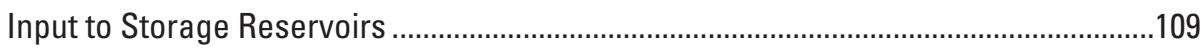

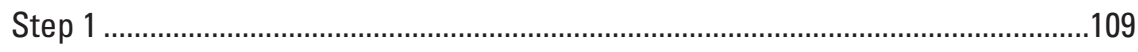

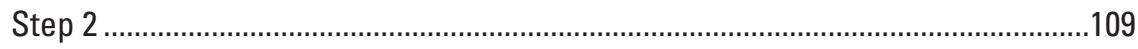

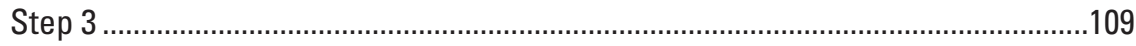

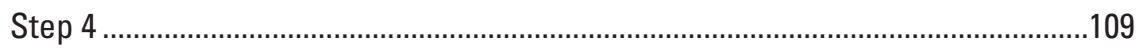

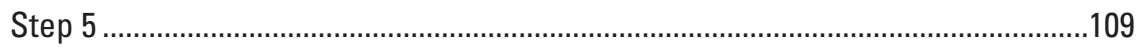

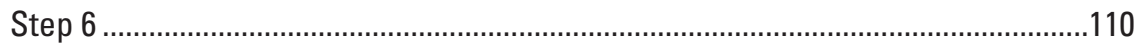

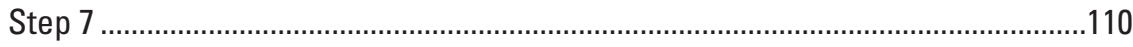

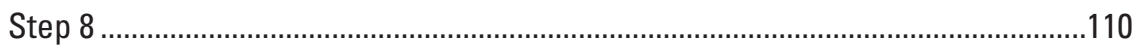

Outflows from Soil-Zone Storage Reservoirs .............................................................111

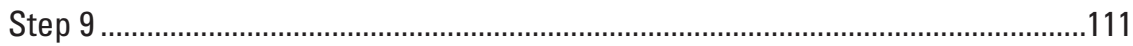

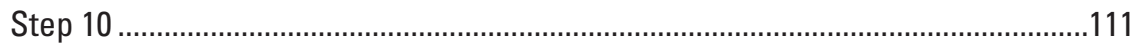

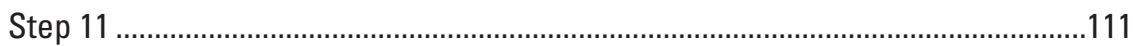

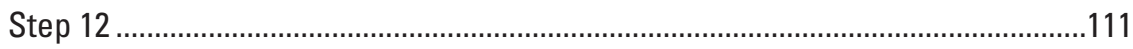

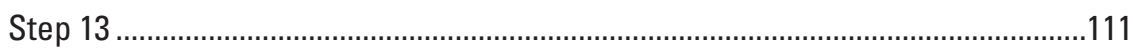

Evapotranspiration from the Capillary Reservoir .......................................................112

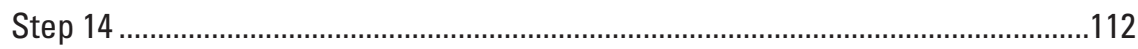

Groundwater-Flow Module: gwflow .......................................................................................113

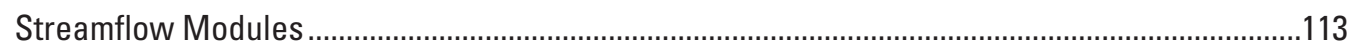

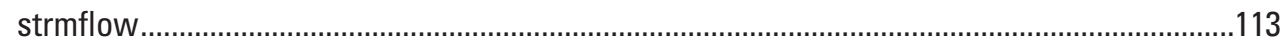

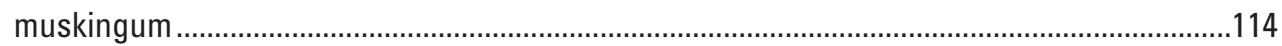

strmflow_in_out .................................................................................................................. 115

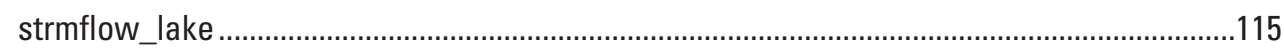

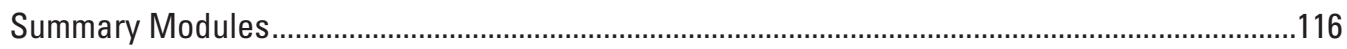

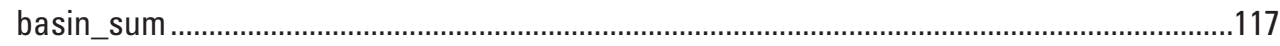

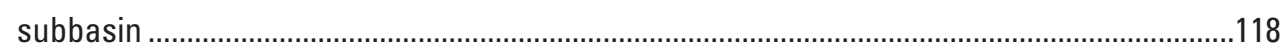

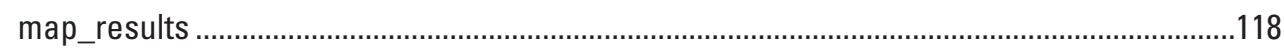

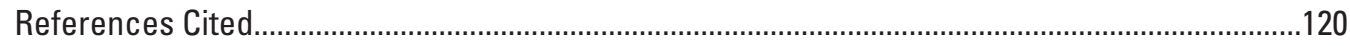




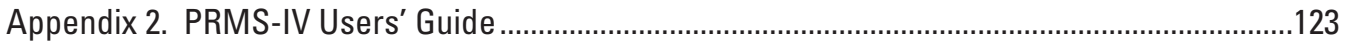

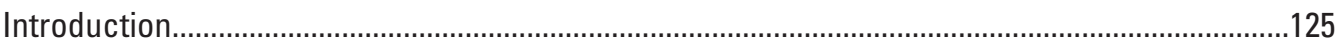

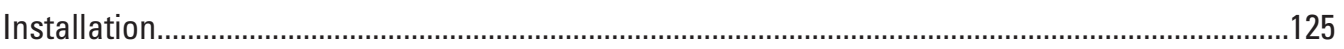

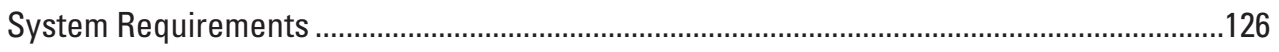

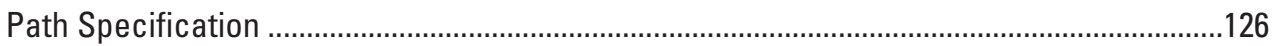

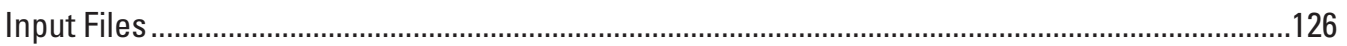

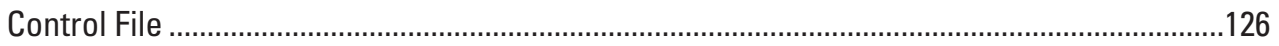

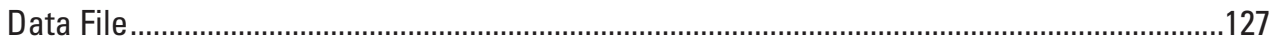

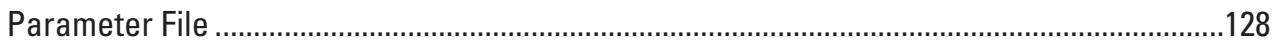

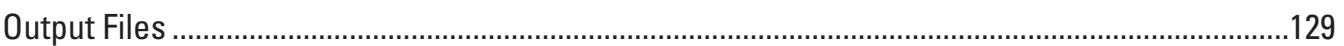

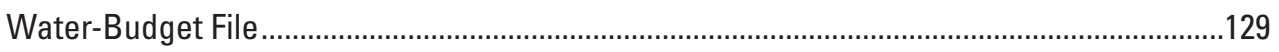

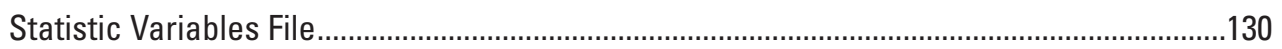

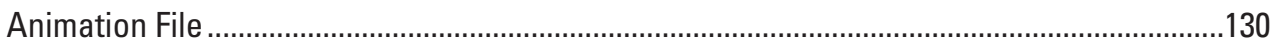

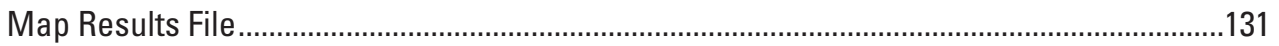

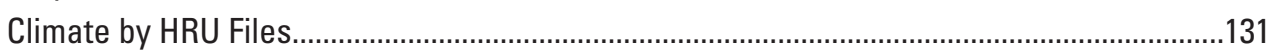

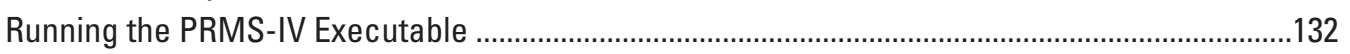

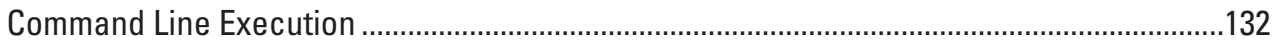

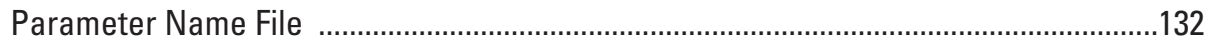

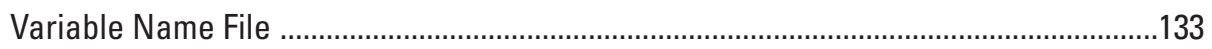

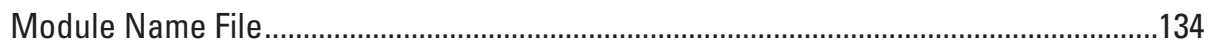

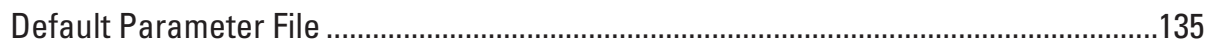

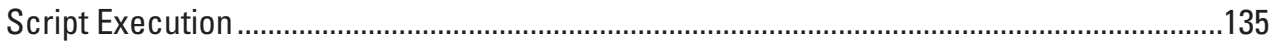

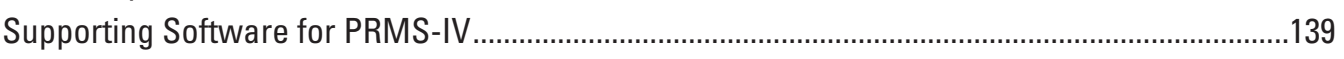

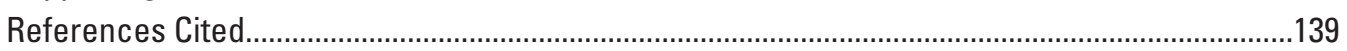

Appendix 3. PRMS-IV Merced River Example Application...........................................................141

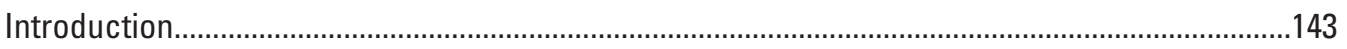

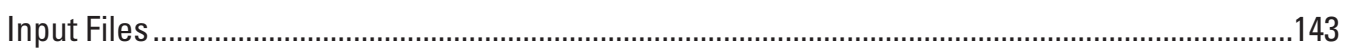

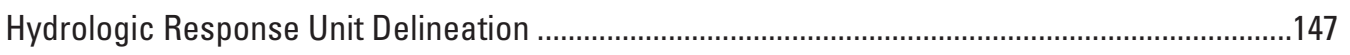

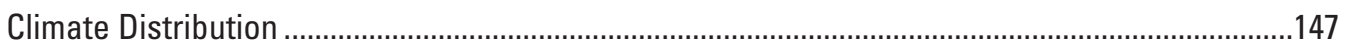

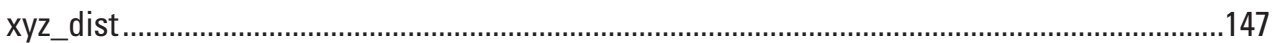

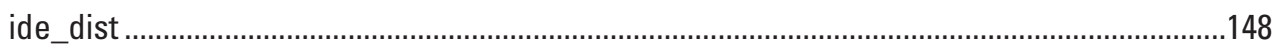

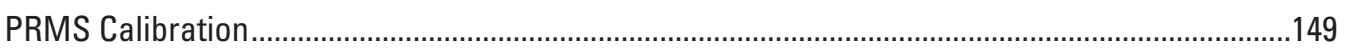

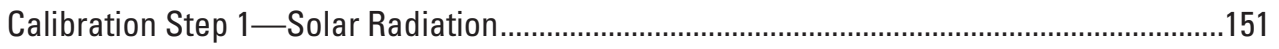

Calibration Step 2-Potential Evapotranspiration ..............................................................151

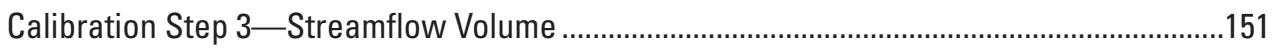

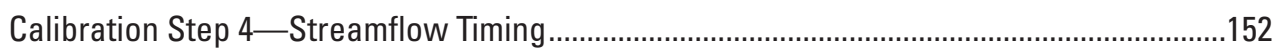

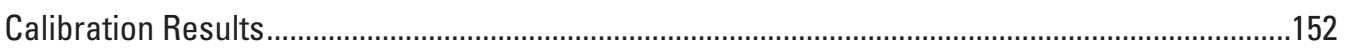

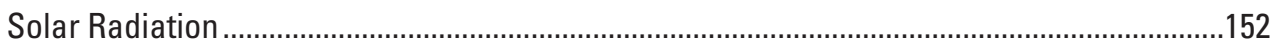

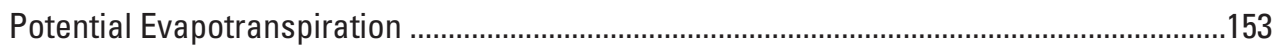

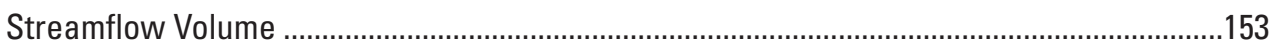

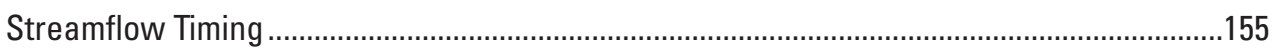

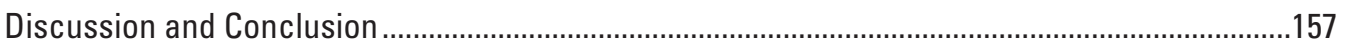

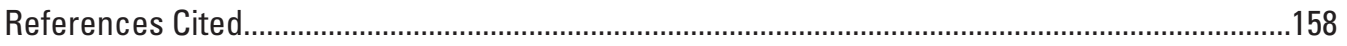




\section{Figures}

1. Hydrological processes simulated by the Precipitation-Runoff Modeling System ...........6

2. Details of the Precipitation Runoff Modeling System Soil Zone ......................................7

3. Components of the snowpack energy balance, accumulation, snowmelt, and

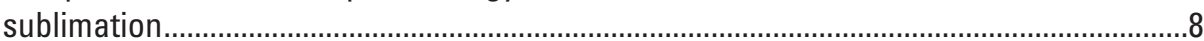

4. Delineation of hydrologic response units of a hypothetical watershed determined from $A$, topology and $B$, topology, climate, and vegetation .............................................10

5. Computational sequence of Precipitation-Runoff Modeling System (PRMS-IV).............16

\section{Tables}

1. Selected applications of the Precipitation-Runoff Modeling System organized by purpose and geographic region.

2. Description of modules implemented in the Precipitation-Runoff Modeling System, version 4 (PRMS-IV)

\section{Conversion Factors}

\begin{tabular}{lcl}
\hline \multicolumn{1}{c}{ Multiply } & By & \multicolumn{1}{c}{ To obtain } \\
\hline centimeter $(\mathrm{cm})$ & 0.3937 & inch (in) \\
meter $(\mathrm{m})$ & 3.281 & foot $(\mathrm{ft})$ \\
kilometer $(\mathrm{km})$ & 0.6214 & mile $(\mathrm{mi})$ \\
square kilometer $\left(\mathrm{km}^{2}\right)$ & 247.1 & acre \\
cubic meter $\left(\mathrm{m}^{3}\right)$ & 35.31 & cubic foot $\left(\mathrm{ft}^{3}\right)$ \\
cubic meter $\left(\mathrm{m}^{3}\right)$ & 0.0008107 & acre-foot $($ acre-ft) \\
cubic meter $\left(\mathrm{m}^{3}\right)$ & 0.009728 & acre-inch $($ acre-in) \\
cubic meter per second $\left(\mathrm{m}^{3} / \mathrm{s}\right)$ & 70.07 & acre-foot per day $($ acre-ft/d) \\
cubic meter per second $\left(\mathrm{m}^{3} / \mathrm{s}\right)$ & 35.31 & cubic foot per second $\left(\mathrm{ft}^{3} / \mathrm{s}\right)$ \\
gram $(\mathrm{g})$ & 0.03527 & ounce, avoirdupois $(\mathrm{oz})$ \\
kilogram $(\mathrm{kg})$ & 2.205 & pound, avoirdupois $(\mathrm{lb})$ \\
joule $(\mathrm{J})$ & 0.0000002 & kilowatthour $(\mathrm{kWh})$ \\
\hline
\end{tabular}

Temperature in degrees Celsius $\left({ }^{\circ} \mathrm{C}\right)$ may be converted to degrees Fahrenheit $\left({ }^{\circ} \mathrm{F}\right)$ as follows:

${ }^{\circ} \mathrm{F}=\left(1.8 \times^{\circ} \mathrm{C}\right)+32$

Temperature in degrees Fahrenheit $\left({ }^{\circ} \mathrm{F}\right)$ may be converted to degrees Celsius $\left({ }^{\circ} \mathrm{C}\right)$ as follows:

${ }^{\circ} \mathrm{C}=\left({ }^{\circ} \mathrm{F}-32\right) / 1.8$

Vertical coordinate information is referenced to the North American Vertical Datum of 1988 (NAVD 88)

Horizontal coordinate information is referenced to the North American Datum of 1983 (NAD 83)

Elevation, as used in this report, refers to distance above the vertical datum. 



\title{
PRMS-IV, The Precipitation-Runoff Modeling System, Version 4
}

\author{
By Steven L. Markstrom, R. Steven Regan, Lauren E. Hay, Roland J. Viger, Richard M. T. Webb, \\ Robert A. Payn, and Jacob H. LaFontaine
}

\section{Abstract}

Computer models that simulate the hydrologic cycle at a watershed scale facilitate assessment of variability in climate, biota, geology, and human activities on water availability and flow. This report describes an updated version of the Precipitation-Runoff Modeling System. The Precipitation-Runoff Modeling System is a deterministic, distributed-parameter, physical-process-based modeling system developed to evaluate the response of various combinations of climate and land use on streamflow and general watershed hydrology. Several new model components were developed, and all existing components were updated, to enhance performance and supportability. This report describes the history, application, concepts, organization, and mathematical formulation of the Precipitation-Runoff Modeling System and its model components. This updated version provides improvements in (1) system flexibility for integrated science, (2) verification of conservation of water during simulation, (3) methods for spatial distribution of climate boundary conditions, and (4) methods for simulation of soil-water flow and storage.

\section{Introduction}

The Precipitation-Runoff Modeling System, version 4 (PRMS-IV) computer software is an updated version of the deterministic, distributed-parameter, physical-process hydrologic model commonly called the Precipitation-Runoff Modeling System (PRMS) (Leavesley and others, 1983). The primary objectives of this new version remain the same as for previous versions: (1) simulation of hydrologic processes including evaporation, transpiration, runoff, infiltration, interflow, and groundwater flow as determined by the energy and water budgets of the plant canopy, snowpack, and soil zone on the basis of distributed climate information (temperature, precipitation, and solar radiation); (2) simulation of hydrologic water budgets at the watershed scale for temporal scales ranging from days to centuries; (3) integration of PRMS with other models used for natural-resource management or with models from other scientific disciplines; and (4) provision of a modular design that allows for selection of alternative hydrologic-process algorithms from the standard PRMS-IV module library. This report documents the design, computations, and application of PRMS-IV.

\section{History}

Several forms of PRMS have existed since the initial release in 1983. The earliest versions were programmed for the mainframe computer systems of that time. Subsequently, in the 1990s, PRMS was reprogrammed to take advantage of engineering workstation computer technology. These predecessors to PRMS-IV are described briefly below.

\section{3}

PRMS was originally developed as a single

FORTRAN 77 program composed of algorithms encoded in subroutines, each representing an individual physical process of the hydrologic cycle (Leavesley, 1973; Leavesley and others, 1981; Leavesley and others, 1983, Leavesley, 1989). For the processes related to temperature distribution, solarradiation distribution, evaporation, transpiration, and surface runoff, two or more different algorithms were encoded, each representing a different approach. A specific algorithm was selected at run time by setting values in the input file. This modular-design concept enabled the creation and application of a model that was most appropriate for a given study and supported the long-term goal to expand the available processsimulation capabilities of PRMS (Leavesley and others, 2005).

The structure of the 1983 version of PRMS substantially differs from PRMS-IV in that the original use of "punch card" formats for input files, line-printer-generated output plots, use of the U.S. Geological Survey's (USGS) National Water Data Storage and Retrieval system (Hutchinson, 1975), and the jobcontrol language specifications necessary to execute PRMS on the Amdahl and Prime computer systems (Leavesley and others, 1983) have been replaced by using files to control program input, execution, and output. 
1996

Although computationally efficient, the procedure required to add hydrologic-process algorithms to the original code was less than adequate. As a result, the architecture and modular structure of PRMS were redesigned to allow better integration and hydrologic-process algorithm-development capabilities. This new structure was the USGS Modular Modeling System (MMS) (Leavesley and others, 1996; Leavesley and others, 2002), an integrated system of computer software developed for simulating a variety of water, energy, and biogeochemical processes that included PRMS. The basic hydrologic-process algorithms in PRMS, as described by Leavesley and Stannard (1995), were maintained in the MMS version; however, the use of MMS enabled the addition of new process algorithms and the enhancement of many of the features and capabilities in the original PRMS (Leavesley and others, 2005). These additions included graphical and networked data systems that took advantage of increased computational power.

\section{4}

The current version of PRMS, PRMS-IV, has been designed as a stand-alone program that can be executed on a Linux or Microsoft Windows platform. In some ways, PRMSIV may appear to return to the concepts and design of the earliest versions of PRMS. Much of the support functionality provided by MMS has been stripped away in favor of a "batch execution" mode for maximum application flexibility and computational efficiency. This approach also supports maximum portability between computers running the Windows and Linux operating systems. Development of PRMS-IV emphasized ease of deployment, installation, and reliability over the MMS concepts of "model building." However, the module and function library developed for the MMS version of PRMS have been shown to be useful and have been retained in PRMS-IV.

\section{Overview of PRMS-IV}

PRMS-IV is a deterministic, distributed-parameter, physical-process hydrologic model used to simulate and evaluate the watershed response of various combinations of climate and land use. Response to normal and extreme rainfall and snowmelt can be simulated to evaluate changes in water-balance relations, streamflow regimes, soil-moisture relations, and groundwater recharge. Each hydrologic process is represented within PRMS-IV by an algorithm that is based on a physical law or an empirical relation with measured or estimated characteristics.

Distributed-parameter capabilities are provided by partitioning a watershed into hydrologic response units (HRUs) that are based on the physical attributes of the watershed such as land-surface elevation, slope and aspect, vegetation type, soil type, and spatiotemporal climate patterns. The phrases "hydrologic response" or "response of the watershed," as used in this report, refer to the effect that the changes in these attributes have on the simulation of the hydrologic processes. The physical attributes and hydrologic response of each HRU are assumed to be homogeneous. A water balance and an energy balance are computed daily for each HRU. The sum of the responses of all HRUs, weighted on a unit-area basis, produces the daily watershed response in the most basic configuration. In addition, PRMS-IV can provide more sophisticated methods of internal routing that are available for more complex modeling applications.

A review of the purpose and accuracy of the hydrologicprocess algorithms in the PRMS-IV library has resulted in a rewrite of the code into the FORTRAN 90 programming language. This rewrite has resulted in (1) a source code that can be integrated more easily with other models such as the USGS coupled Ground-water and Surface-water FLOW model (GSFLOW) (Markstrom and others, 2008); (2) greater stability and reliability; (3) improved maintainability and supportability; and (4) self-generated documentation. In addition, care has been taken to ensure that simulation results from PRMS-IV are comparable to previous versions of PRMS; however, bug fixes, updated algorithms, and evolving model structure may result in differences between the calculations made by PRMSIV and previous versions of the code.

\section{Application of PRMS}

Since the initial release, there have been many applications of PRMS. For example, there have been many PRMS-modeling applications developed for water and natural-resource management; these applications evaluate the hydrologic response to changes in watershed conditions. In more recent years, PRMS has been used to evaluate the hydrologic response to climate change. Table 1 lists some of these applications, within the United States and abroad, organized by their geographic setting and primary purpose. 
Table 1. Selected applications of the Precipitation-Runoff Modeling System organized by purpose and geographic region.

\begin{tabular}{|c|c|c|c|c|c|c|c|}
\hline \multirow[t]{2}{*}{$\begin{array}{l}\text { Primary } \\
\text { purpose }\end{array}$} & \multicolumn{7}{|c|}{$\begin{array}{l}\text { Geographic } \\
\text { region }\end{array}$} \\
\hline & Northwest & Northeast & Southwest & $\begin{array}{c}\text { Rocky } \\
\text { Mountains }\end{array}$ & Great Plains & Southeast & Others \\
\hline $\begin{array}{l}\text { Model } \\
\text { Calibration } \\
\text { and Parameter } \\
\text { Estimation }\end{array}$ & $\begin{array}{l}\text { Ely, 2006; Hay } \\
\text { and others, } \\
2006 a\end{array}$ & & $\begin{array}{l}\text { Dressler and } \\
\text { others, } 2006\end{array}$ & $\begin{array}{l}\text { Hay and others, } \\
\text { 2006b; Kuhn } \\
\text { and Parker, } \\
1992\end{array}$ & & $\begin{array}{l}\text { Rivera-Santos, } \\
1990\end{array}$ & $\begin{array}{l}\text { Hay and } \\
\text { Umemoto, } \\
\text { 2007; Duan } \\
\text { and others, } \\
\text { 2006; Leaves- } \\
\text { ley and others, } \\
\text { 2003; Barrett } \\
\text { and others, } \\
\text { 2000; Flügel } \\
\text { and Lüllwitz, } \\
\text { 1993; World } \\
\text { Meteorological } \\
\text { Organization, } \\
\text { 1986; Trout- } \\
\text { man, 1985 }\end{array}$ \\
\hline $\begin{array}{l}\text { Water- and } \\
\text { Natural- } \\
\text { Resource } \\
\text { Management }\end{array}$ & $\begin{array}{l}\text { Mastin, 2009; } \\
\text { van Heeswijk, } \\
\text { 2006; Mastin } \\
\text { and Vaccaro, } \\
\text { 2002a; Mastin } \\
\text { and Vaccaro, } \\
\text { 2002b; Lee and } \\
\text { Risley, 2001; } \\
\text { Laenen and } \\
\text { Risley, 1997; } \\
\text { Risley, 1994; } \\
\text { Nakama and } \\
\text { Risley, } 1993\end{array}$ & $\begin{array}{l}\text { Ahearn and } \\
\text { Bjerklie, 2010; } \\
\text { Dudley, } 2008\end{array}$ & $\begin{array}{l}\text { Markstrom and } \\
\text { Koczot, 2008; } \\
\text { Koczot and } \\
\text { others, 2005; } \\
\text { Leavesley and } \\
\text { others, 2002; } \\
\text { Berris and } \\
\text { others, 2001; } \\
\text { Jeton, 1999; } \\
\text { Jeton, 2000; } \\
\text { Jeton and oth- } \\
\text { ers, 1996; Hejl, } \\
\text { 1989 }\end{array}$ & $\begin{array}{l}\text { Markstrom } \\
\text { and others, } \\
\text { 2001; Ryan, } \\
\text { 1996; Fulp and } \\
\text { others 1995; } \\
\text { Kuhn, 1989; } \\
\text { Parker and } \\
\text { Norris, 1989; } \\
\text { Norris, 1986; } \\
\text { Brendecke and } \\
\text { others, 1985; } \\
\text { Brendecke and } \\
\text { Sweeten, 1985; } \\
\text { Norris and } \\
\text { Parker, 1985 }\end{array}$ & $\begin{array}{l}\text { Cary, 1991; } \\
\text { Cary, } 1984\end{array}$ & $\begin{array}{l}\text { Puente and } \\
\text { Atkins, 1989; } \\
\text { Kidd and } \\
\text { Bossong, 1987; } \\
\text { Bower, 1985; } \\
\text { Scott, } 1984\end{array}$ & $\begin{array}{l}\text { Leavesley, } \\
\text { 2005a; Leaves- } \\
\text { ley, 2005b; } \\
\text { Yeung, 2005; } \\
\text { Leavesley, } \\
\text { 1999a; Leaves- } \\
\text { ley, 1999b; } \\
\text { Leavesley and } \\
\text { Hay, 1998; } \\
\text { Stannard and } \\
\text { Kuhn, } 1989\end{array}$ \\
\hline
\end{tabular}


Table 1. Selected applications of the Precipitation-Runoff Modeling System organized by purpose and geographic region.-Continued

\begin{tabular}{|c|c|c|c|c|c|c|c|}
\hline \multirow[t]{2}{*}{$\begin{array}{l}\text { Primary } \\
\text { purpose }\end{array}$} & \multicolumn{7}{|c|}{$\begin{array}{l}\text { Geographic } \\
\text { region }\end{array}$} \\
\hline & Northwest & Northeast & Southwest & $\begin{array}{c}\text { Rocky } \\
\text { Mountains }\end{array}$ & Great Plains & Southeast & Others \\
\hline $\begin{array}{l}\text { Interaction of } \\
\text { Groundwater } \\
\text { and Surface } \\
\text { water }\end{array}$ & $\begin{array}{l}\text { Vaccaro, 2007; } \\
\text { Vaccaro, } 1992\end{array}$ & $\begin{array}{l}\text { Bjerklie and } \\
\text { others, } 2010\end{array}$ & $\begin{array}{l}\text { Markstrom and } \\
\text { others, 2008; } \\
\text { Jeton and Mau- } \\
\text { rer, } 2007\end{array}$ & & & & $\begin{array}{l}\text { Steuer and } \\
\text { Hunt, 2001; } \\
\text { Hunt and } \\
\text { Steuer, 2001 }\end{array}$ \\
\hline $\begin{array}{l}\text { Interaction of } \\
\text { Climate and } \\
\text { Atmosphere } \\
\text { with Surface } \\
\text { water }\end{array}$ & $\begin{array}{l}\text { Mastin and } \\
\text { others, } 2011\end{array}$ & $\begin{array}{l}\text { Bjerklie and } \\
\text { others, } 2011\end{array}$ & $\begin{array}{l}\text { Koczot and } \\
\text { others, 2011; } \\
\text { Boyle and } \\
\text { others, 2006; } \\
\text { Dettinger and } \\
\text { others, } 2004\end{array}$ & $\begin{array}{l}\text { Battaglin and } \\
\text { others, 2011; } \\
\text { Hay and others, } \\
\text { 2006c; Wilby } \\
\text { and others, } \\
\text { 1999; Hay and } \\
\text { Clark, 2003; } \\
\text { Hay and others, } \\
\text { 2000; McCabe } \\
\text { and Hay, 1995; } \\
\text { Battaglin and } \\
\text { others, 1993; } \\
\text { Hay and oth- } \\
\text { ers, } 1993\end{array}$ & & $\begin{array}{l}\text { Viger and oth- } \\
\text { ers, } 2011\end{array}$ & $\begin{array}{l}\text { Markstrom and } \\
\text { others, 2012; } \\
\text { Christiansen } \\
\text { and others, } \\
\text { 2011; Hay and } \\
\text { others, 2011; } \\
\text { Milly and } \\
\text { Dunne, 2011; } \\
\text { Risley and } \\
\text { others, 2011; } \\
\text { Walker and } \\
\text { others, 2011; } \\
\text { Markstrom } \\
\text { and Hay, } \\
\text { 2009;Hay and } \\
\text { others, 2002; } \\
\text { Clark and Hay, } \\
\text { 2004; Gibson } \\
\text { and others, } \\
\text { 2005; Hay } \\
\text { and McCabe, } \\
\text { 2002; Wilby } \\
\text { and others, } \\
\text { 2000; Hay and } \\
\text { others, 2000; } \\
\text { Clark and Hay, } \\
\text { 2000 }\end{array}$ \\
\hline Other & $\begin{array}{l}\text { Leavesley and } \\
\text { others, } 1989\end{array}$ & Olson, 2002 & & $\begin{array}{l}\text { Yates and } \\
\text { others, 2001; } \\
\text { Yates and oth- } \\
\text { ers, } 2000\end{array}$ & $\begin{array}{l}\text { Vining, 2004; } \\
\text { Leavesley, } \\
\text { 2002; Vining, } \\
\text { 2002; } \\
\text { Emerson, } \\
\text { 1991; Rank1, } \\
\text { 1987; Carey } \\
\text { and Simon, } \\
\text { 1984 }\end{array}$ & & Reed, 1986 \\
\hline
\end{tabular}




\section{Purpose and Scope}

This report describes PRMS-IV, a modular computer program for modeling watershed hydrologic processes. Previously, PRMS has been documented in Leavesley and others (1983), Leavesley and others (1996), and Markstrom and others (2008). This report supersedes these reports in the description, design, implementation, and application of PRMS-IV.

To support users and developers of PRMS-IV, technical information is presented in three appendixes to this report. Appendix 1 provides detailed documentation of the hydrologic-process simulation modules included with PRMS-IV. Appendix 2 is the PRMS-IV Users' Guide and provides an overview of practical ways to work with PRMS-IV. Appendix 3 presents an example application of PRMS-IV, which demonstrates several options and capabilities.

\section{Concepts and Definitions}

Selected concepts and definitions of PRMS-IV are presented in this section as background for the more detailed information provided later in the report. These concepts define and explain some of the key ideas of PRMS-IV. PRMS-IV users are advised to consult the appendixes of this report for the detailed documentation necessary to build a PRMS-IV application.

\section{Conceptual Model of the Watershed}

The PRMS-IV conceptual model of a watershed (figs. 1 and 2) originally was described by Leavesley and others (1983) and is summarized here. Inputs to the hydrologic model are daily time-series values of precipitation, minimum and maximum air temperature, and short-wave solar radiation. Daily short-wave solar radiation can be estimated internally by the model if it is not provided by the user. Precipitation in the form of rain, snow, or a mixture of both is reduced by vegetative canopy interception; precipitation not intercepted by the canopy becomes the net precipitation throughfall that is delivered to the watershed surface. Energy inputs of air temperature and solar radiation drive the processes of evaporation, transpiration, sublimation, and snowmelt. The structure of the watershed is conceptualized as a series of reservoirs, stream segments, and lakes. Use of the term "reservoir" in this report, and within the context of describing PRMS-IV, refers to the conceptual water-storage mechanism in the PRMS-IV model and not to a physical pond or lake used for the storage and regulation of water (for example, the conceptual water-storage reservoirs [preferential-flow, capillary, and gravity reservoirs] shown in fig. 2). For each time step of the simulation, the amount of water stored in the reservoirs, stream segments, and lakes is referred to as the "state." The amount of water moving between these elements is referred to as the "flux." The simulated hydrologic response of the watershed is characterized by these states and fluxes. PRMS-IV maintains a water balance on the entire watershed as well as on the individual reservoirs, stream segments, and lakes.

The soil-zone represents that part of the soil mantle that can lose water through evaporation and transpiration. The depth of the soil-zone is defined by the average rooting depth of the dominant vegetation type covering the soil surface. Water storage in the soil zone is increased by the infiltration of rainfall and snowmelt and depleted by evaporation and transpiration. Infiltration is net precipitation minus surface runoff. Soil-water storage and flux in the soil zone is accounted for with a series of conceptual reservoirs, as described in the "Soil-Zone and Groundwater Storage Reservoirs" section and Appendix 1 in this report. Water moves between these reservoirs on the basis of antecedent conditions and soil properties. The impervious-zone reservoir represents an area with no infiltration capacity. This reservoir has a maximum retentionstorage capacity that must be satisfied before surface runoff to streams will occur (Leavesley and others, 1983).

Snowmelt is determined by a water and energy balance computed on snowpacks, which accumulate, sublimate, and melt (fig. 3). Net precipitation and surface runoff can contribute to surface depression storage (fig. 2). Depression storage is depleted by spillage and evaporation. Recharge to the groundwater reservoir (fig. 1) comes from the soil zone. This groundwater subsequently becomes groundwater flow to streams and lakes. Water can also leave the groundwater reservoir through the groundwater sink, which represents transbasin groundwater flow or under gage streamflow.

Lateral inflows to the stream channels are computed as the sum of the surface runoff, subsurface reservoir flow, and groundwater flow. In more complex watersheds, water can cascade from reservoir to reservoir before it reaches the stream channels. Streamflow can also be stored and attenuated by lakes.

\section{Spatial Discretization}

PRMS-IV requires that the subject watershed be spatially discretized into a set of unique hydrologic units. This process of spatial discretization usually is accomplished through the use of a geographic information system (GIS) computer program. Discretization allows for spatial variability in model input and simulation results. These results can be evaluated at each individual unit or at groups of units. A PRMS-IV application is based on five types of spatial units: (1) the model domain, (2) stream segments, (3) HRUs, (4) lakes, and (5) subbasins. 


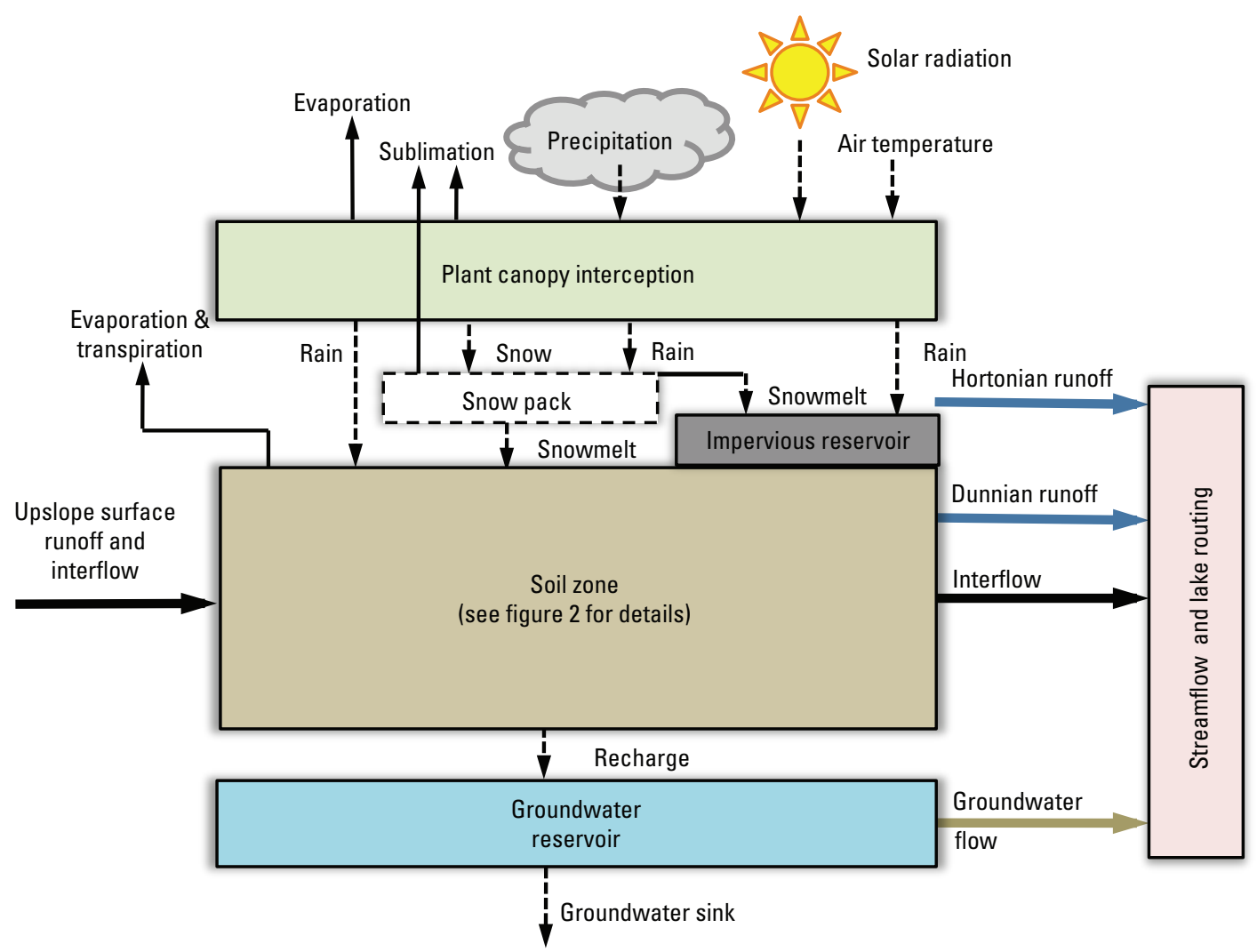

Figure 1. Hydrological processes simulated by the Precipitation-Runoff Modeling System (modified from Markstrom and others, 2008). 


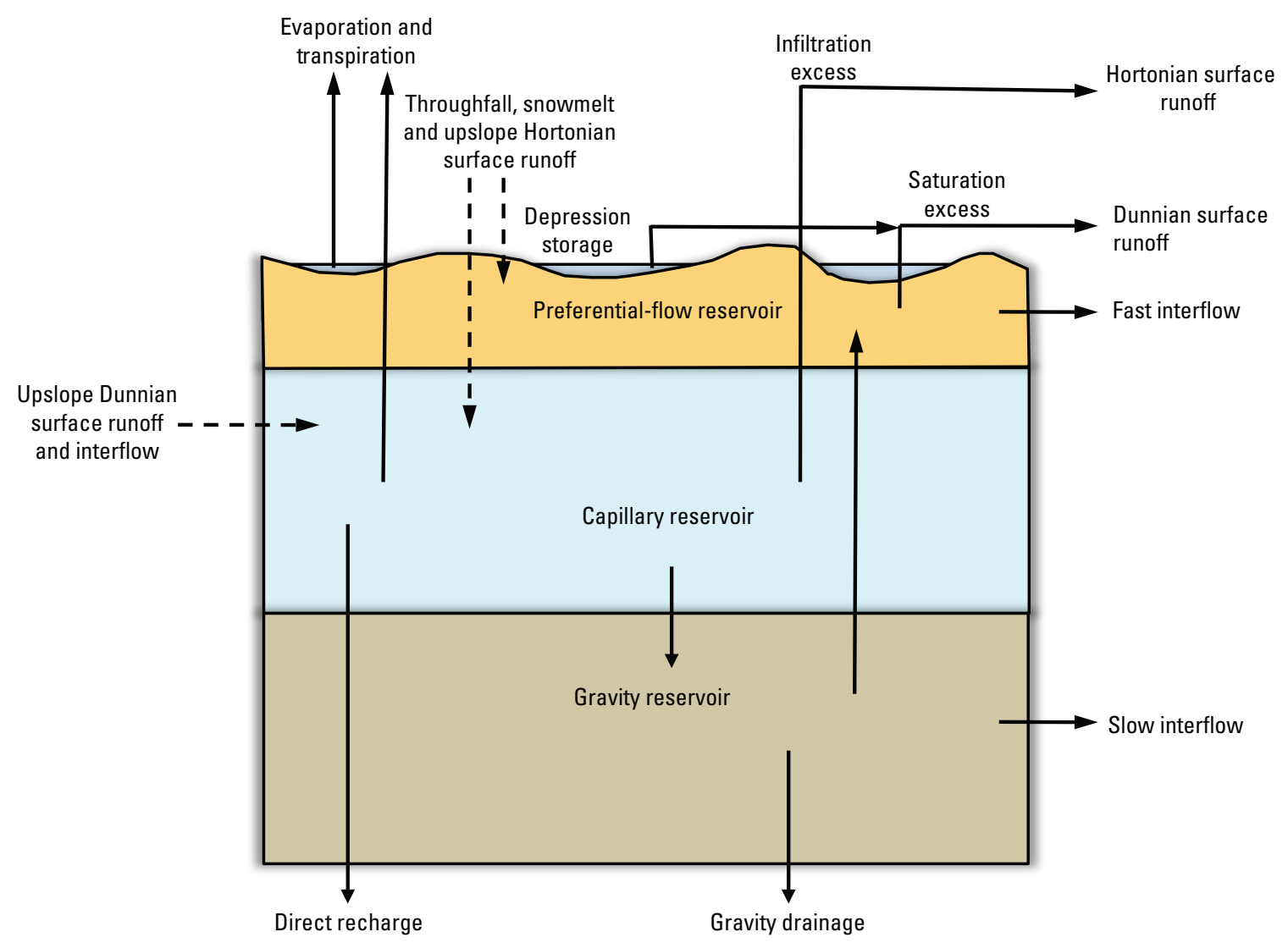

Figure 2. Details of the Precipitation-Runoff Modeling System Soil Zone. 


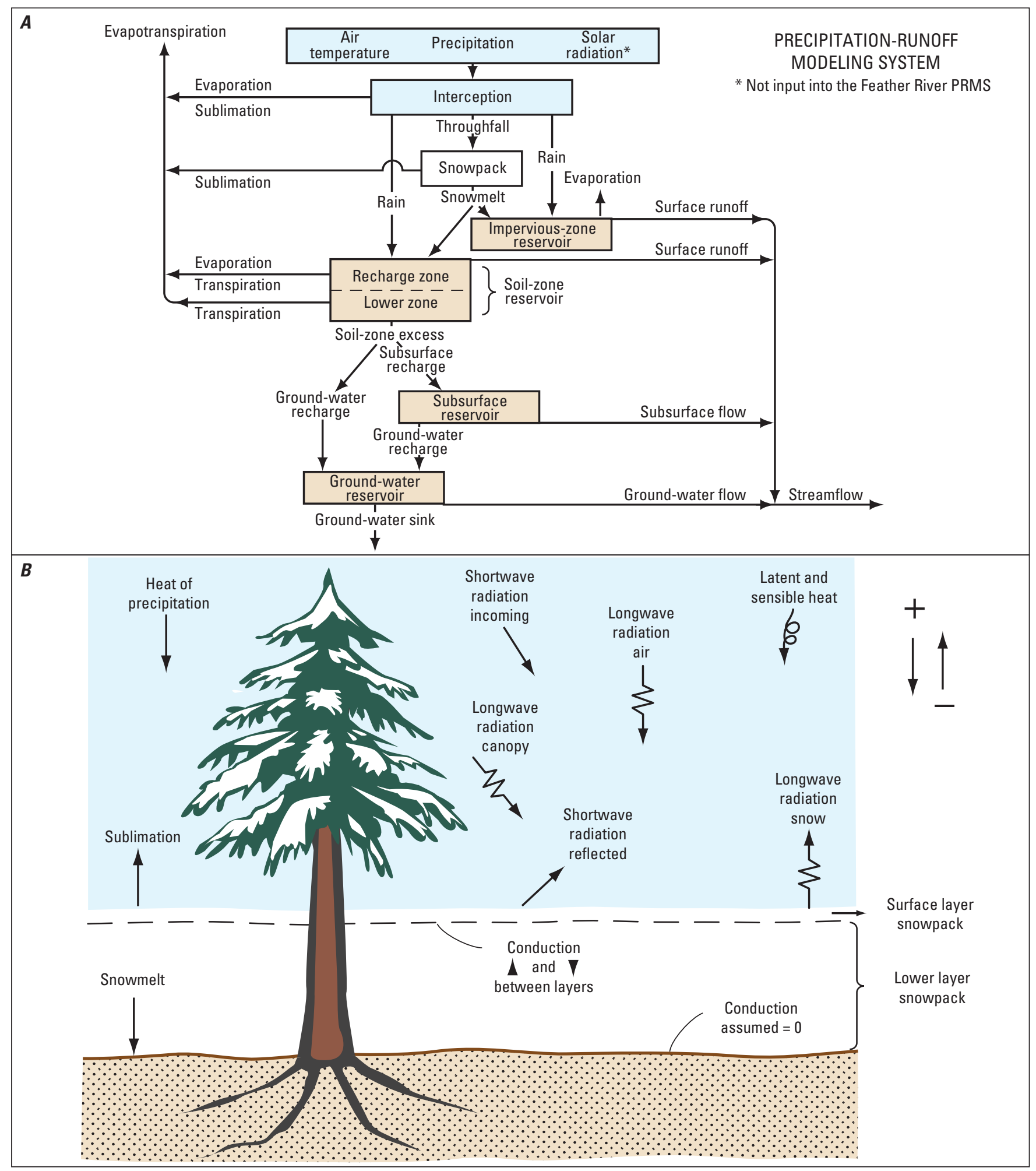

Figure 3. Components of the snowpack energy balance, accumulation, snowmelt, and sublimation (from Koczot and others, 2005). 


\section{Model Domain}

Precise specification of the geographic area to be simulated by PRMS-IV is required. This geographic area is called the "model domain." A typical model domain for PRMS-IV comprises one or more surface watersheds, in which a watershed is defined as the area of land that drains into a stream above a given location (Chow and others, 1988, p. 7). Other ways to define the model domain may include (1) boundaries defined by other simulation models, or (2) anthropogenic regions such as urban areas, agricultural fields, or political boundaries.

\section{Stream Segments}

A stream segment is the smallest geographic feature for simulation of channelized flow occurring in a watershed. This flow can be ephemeral, intermittent, or perennial. A drainage network comprised of one or more stream segments must be bounded by the model domain. PRMS-IV will calculate lateral flows, inflow, and outflow at every stream segment. In addition, users can specify the flow at any stream segment.

\section{Hydrologic Response Units}

The model domain is discretized into a network of landsurface HRUs. The discretization can be based on hydrologic and physical characteristics such as drainage divides; landsurface elevation, slope, and aspect; vegetation type and cover; land use; distribution of precipitation, temperature, and solar radiation; soil morphology and geology; and flow direction. Each HRU is assumed to be homogeneous with respect to these hydrologic and physical characteristics and to its hydrologic response. In PRMS-IV, a water balance and an energy balance are computed at each simulation time step for each HRU. Each HRU is identified by a numerical index. Assignment of the index to the HRU is arbitrary, but indexes must be unique, consecutive, and start with 1 .

The delineation of the model domain into HRUs can be automated with the aid of a GIS analysis. One of three different delineation approaches is typically used (Viger and Leavesley, 2007): (1) a topological approach, which results in irregularly shaped hill slopes and flow planes; (2) a gridbased approach, which results in regular rectangles; or (3) a noncontiguous approach, which results in many unique and irregularly shaped polygons, determined by combinations of watershed characteristics, which could include topology, climate, and vegetation. Two examples of HRU delineation of a hypothetical watershed are shown in figure 4 .

In PRMS-IV, each HRU can be designated as one of four types: land, lake, swale, or inactive. A land HRU is the most common type of HRU; land HRUs simulate all of the hydrologic processes shown in figures 1 and 2. Many applications consist only of land HRUs. When the model domain includes large lakes, these areas should be delineated separately and designated as a lake-type HRU. Swales are land-type HRUs in which the surface runoff and interflow components of lateral flow are not present. These HRUs typically correspond to low areas in the model domain that capture flow and only contribute to groundwater flow. Inactive HRUs allow for areas within the model domain to be excluded from the PRMS-IV simulation. This option is used for calibration purposes and integration with other simulation models.

\section{Lakes}

A lake is a special type of HRU, which is simulated with different algorithms that are applicable for hydrological properties of lakes. Lake HRUs are usually delineated on the basis of their geographical extent at the high-water level. In PRMSIV, water bodies can be simulated as either lake-type HRUs, or surface-depression storage within land-type HRUs. How specific water bodies should be simulated depends on their size, and more importantly, on the effect that the water body has on the hydrologic response of the watershed.

\section{Subbasins}

A sub-area of the model domain that contributes streamflow to a specific point (for example, a streamgage, control structure, or stream segment) can be identified as a subbasin. Subbasins are defined as sets of HRUs and typically are used for streamflow accounting within part of a watershed.

\section{Temporal Discretization}

The continuum of time, for a user-defined period, must be discretized into a series of daily time steps for a PRMS-IV simulation.

\section{Soil-Zone and Groundwater Storage Reservoirs}

PRMS-IV accounts for soil-zone water content with a conceptual three-reservoir system (figs. 1 and 2). Use of the term "reservoir" refers to the conceptual water-storage mechanism and not to a physical pond or lake used for the storage and regulation of water. These conceptual soil-zone reservoirs are the preferential-flow, capillary, and gravity reservoirs, and are coincident in physical space (fig. 2). How water moves between and is stored within the soil-zone and groundwater reservoirs determines much of the capability and limitation of PRMS-IV to predict streamflow. The names of these reservoirs have changed from previous versions of PRMS and are described in more detail in Appendix 1 of this report. 
$\boldsymbol{A}$

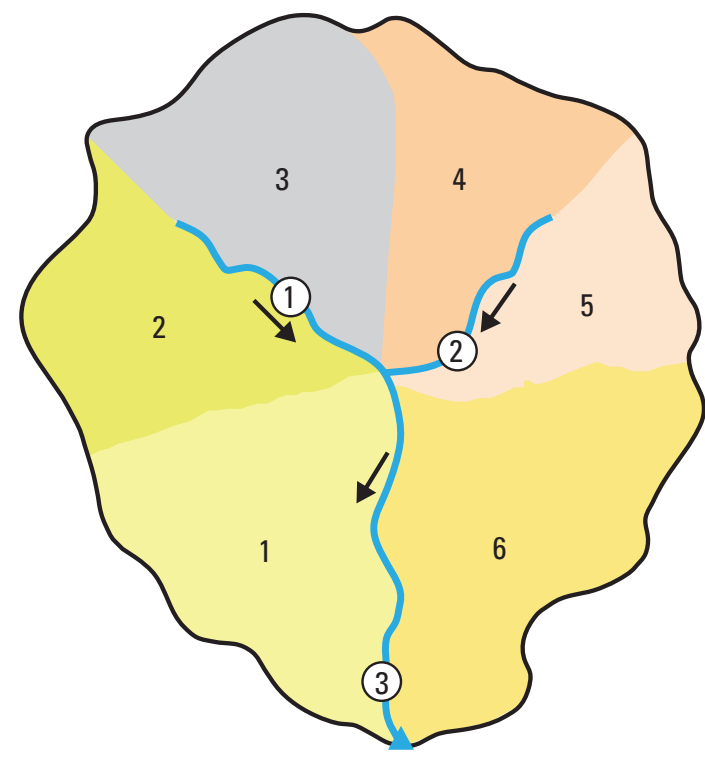

B

EXPLANATION

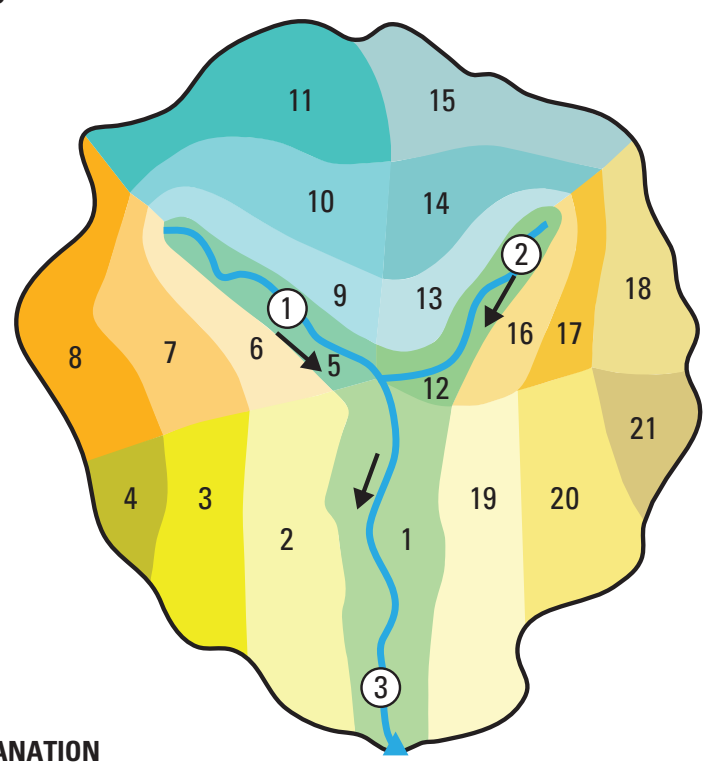

$7 \quad$ Hydrologic response unit and number

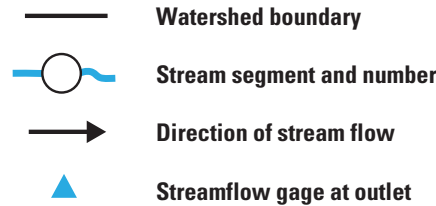

Figure 4. Delineation of hydrologic response units of a hypothetical watershed determined from $A$, topology and $B$, topology, climate, and vegetation (from Markstrom and others, 2008).

\section{Preferential-Flow Reservoirs}

Soil-water content over the field-capacity threshold can be apportioned to the preferential-flow reservoir. This reservoir accounts for fast lateral interflow through large openings in the soil profile. The capacity of the preferential-flow reservoir is determined by the difference between total soil saturation and field capacity. Previous versions of PRMS do not account for preferential-flow reservoirs.

\section{Capillary Reservoirs}

The capillary reservoir represents the soil-water content between the wilting and field-capacity thresholds. Soil water in this reservoir is held by capillary forces and is immobile. The capacity of this reservoir is sometimes referred to as the available water content of the soil profile. Antecedent conditions of the capillary reservoir affect infiltration, evapotranspiration, and surface runoff. Capillary reservoirs are only simulated in the pervious portions of an HRU. Capillary reservoirs were called soil-zone reservoirs in previous versions of PRMS.

\section{Gravity Reservoirs}

Soil-water content over the field-capacity threshold also can be apportioned to the gravity reservoir. This reservoir accounts for slow, lateral interflow and drainage to the groundwater reservoir from the soil profile. The capacity of a gravity reservoir is determined by the difference between total soil saturation and field capacity minus the capacity of the preferential-flow reservoir. Gravity reservoirs were called subsurface reservoirs in previous versions of PRMS.

\section{Groundwater Reservoirs}

Water moves into the groundwater reservoir as vertical flow from the soil zone (recharge, fig. 1). The primary purpose of the groundwater reservoir is to account for the baseflow component of streamflow. Water moves out of the groundwater reservoir as groundwater flow to the stream network or to the groundwater sink, which is water that leaves the model domain. 


\section{Organization of PRMS-IV}

\section{Processes}

The PRMS-IV simulation of the hydrologic cycle of a watershed is broken into 17 processes, defined in the "Implementation" section and fully documented in Appendix 1 of this report. Each of these processes represents either one of the major hydrological processes (for example, surface runoff, interflow, or groundwater flow) or an administrative task (for example, reading of input data or output report generation). Each process is executed in the correct order by PRMS-IV for the simulation of the hydrologic response of the watershed.

\section{Modules}

A module is computer source code used to simulate a hydrologic process. The term "module" in this report refers to this source code, unless otherwise specified. A given process can have several modules in the library, each representing an alternative conceptualization or approach to simulation of the hydrologic process. Each module needs specific inputs to execute, and computes specific outputs that can be used as inputs to other modules. Each module has four system callable functions: declare, initialize, run, and cleanup. These functions are called by PRMS-IV to perform the simulation. Modules communicate their input and output to each other through a well-defined memory structure.

\section{Parameters, Variables, and Dimensions}

A parameter is an input value that does not change during the course of a PRMS-IV simulation, such as the area of each HRU. The actual parameters used in the simulation are determined by the modules that have been selected. The numerical values of each parameter are read from the PRMS-IV Parameter File before the simulation is initiated. The format of this file is described in the "Input and Output Files" section of this report. The parameters that are required for each module are defined in Appendix 1.

A variable is a value that can change each time step during the course of a PRMS-IV simulation, such as the specified daily values of precipitation (input) and computed values of soil-moisture content (output). Input variables are read at each simulation time step from the PRMS-IV Data File. Output variables are computed each time step by the modules. These output variables are available as input to other modules or as output to files. The format of both input- and output-variable files is described in the "Input and Output Files" section of this report. The actual variables used in the simulation are determined by the modules that have been selected and are defined in Appendix 1.
A dimension is a value used to describe the array size (number of values) of a parameter or a variable. In PRMS-IV, all parameters and variables are implemented as arrays and have one or more dimensions associated with them. The value of each dimension is specified in the PRMS-IV Parameter File, as described in the "Input and Output Files" section of this report. All PRMS-IV dimensions are defined in Appendix 1.

\section{Implementation}

The elements of the PRMS-IV conceptual model, described in the previous section, are implemented as a set of modules that are summarized below and described in detail in Appendix 1. This section also describes the sequence that the modules are called in PRMS-IV and summarizes the input and output files required for a PRMS-IV simulation.

\section{Processes and Modules}

The hydrologic cycle is simulated in PRMS-IV by 17 processes, resulting in a total of 39 modules (table 2 ) that currently are supported. Table 2 also lists 8 modules that are depricated not supported or described in this report, but are included in PRMS-IV for backwards compatability. The Climate-by-HRU (CBH) Distribution module (climate_hru) is listed in the table for six processes as it can be used for an individual process (temperature, precipitation, solar radiation, transpiration, and potential evapotranspiration) or in any combination of processes (combined). These modules are written in FORTRAN 90. Some modules have been revised from previous PRMS versions, while others are new for PRMS-IV. One module is used to simulate each process. Each module is summarized here and fully documented in Appendix 1.

When more than one module is available for simulation of a process, the user can choose which module to use by specifying it as input in the Control File. The Control File is a required input file in which the user specifies settings that control how PRMS-IV will run. The content of the Control File is described in the "Input Files" section of this report and the format of the Control File is described in Appendix 2.

\section{Basin Definition Process}

The Basin Definition module (bas in) sets up many of the domain-wide variables, checks the validity of HRU physical parameters, computes the area and volume of the conceptual storage reservoirs, and determines the routing order between geographical features. Because there is only one module available to simulate this process, the user does not specify this selection in the Control File. 
Table 2. Description of modules implemented in the Precipitation-Runoff Modeling System, version 4 (PRMS-IV).

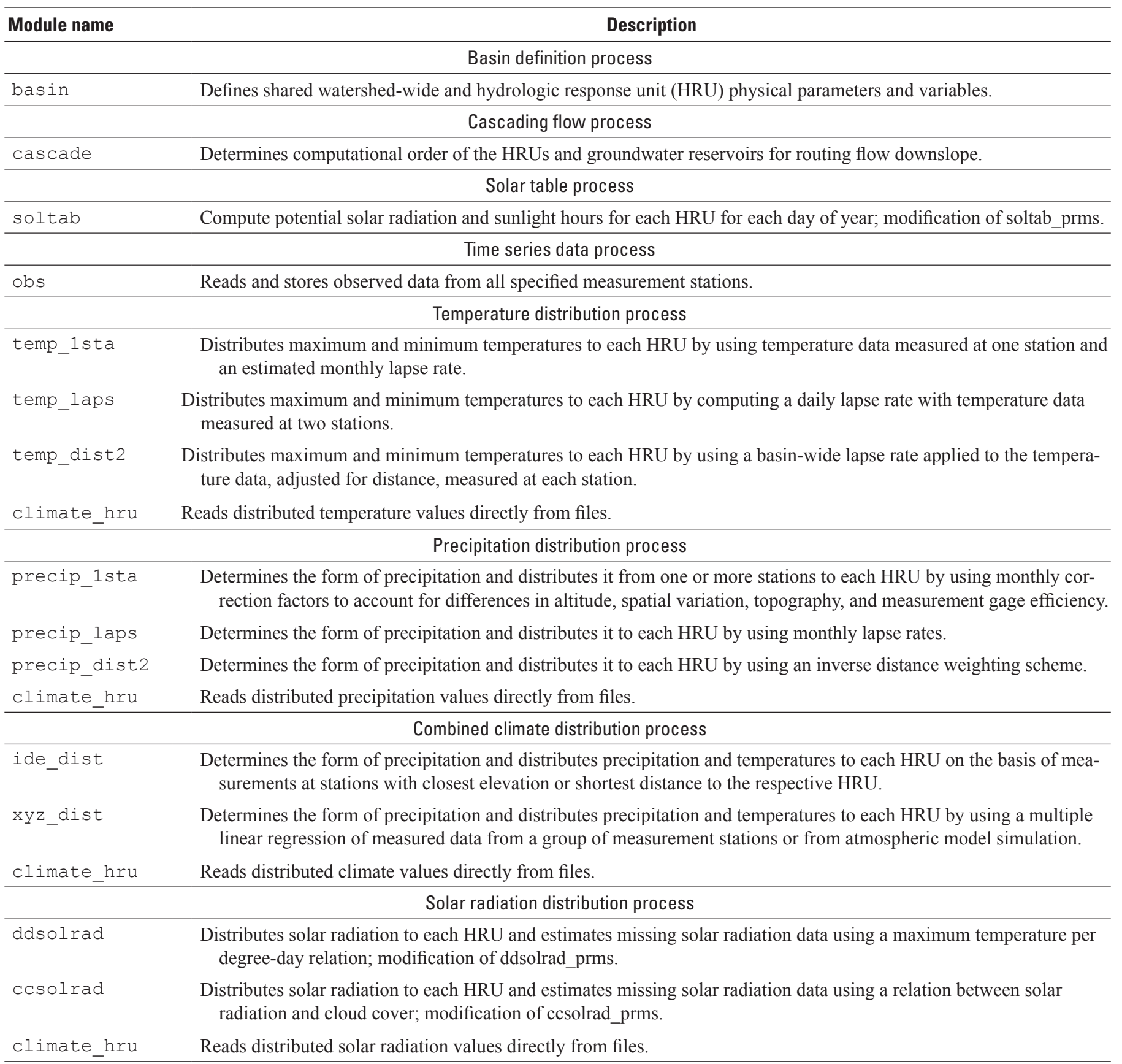

\section{Transpiration period process}

transp_frost Determines whether the current time step is in a period of active transpiration by the killing frost method.

transp_tindex Determines whether the current time step is in a period of active transpiration by the temperature index method.

climate_hru Reads the state of transpiration directly from files.

\section{Potential evapotranspiration process}

potet_hamon

potet_jh

Computes the potential evapotranspiration by using the Hamon formulation (Hamon, 1961); modification of potet_hamon_prms.

potet_hs

Computes the potential evapotranspiration by using the Jensen-Haise formulation (Jensen and Haise, 1963).

potet_pt

Computes the potential evapotranspiration by using the Hargreaves-Samani formulation (Hargreaves and Samani, 1982).

potet_pm

Computes the potential evapotranspiration by using the Priestley-Taylor formulation (Priestley and Taylor, 1972).

Computes the potential evapotranspiration by using the Penman-Monteith formulation (Penman, 1948; Monteith, 1965). 
Table 2. Description of modules implemented in the Precipitation-Runoff Modeling System, version 4 (PRMS-IV).-Continued

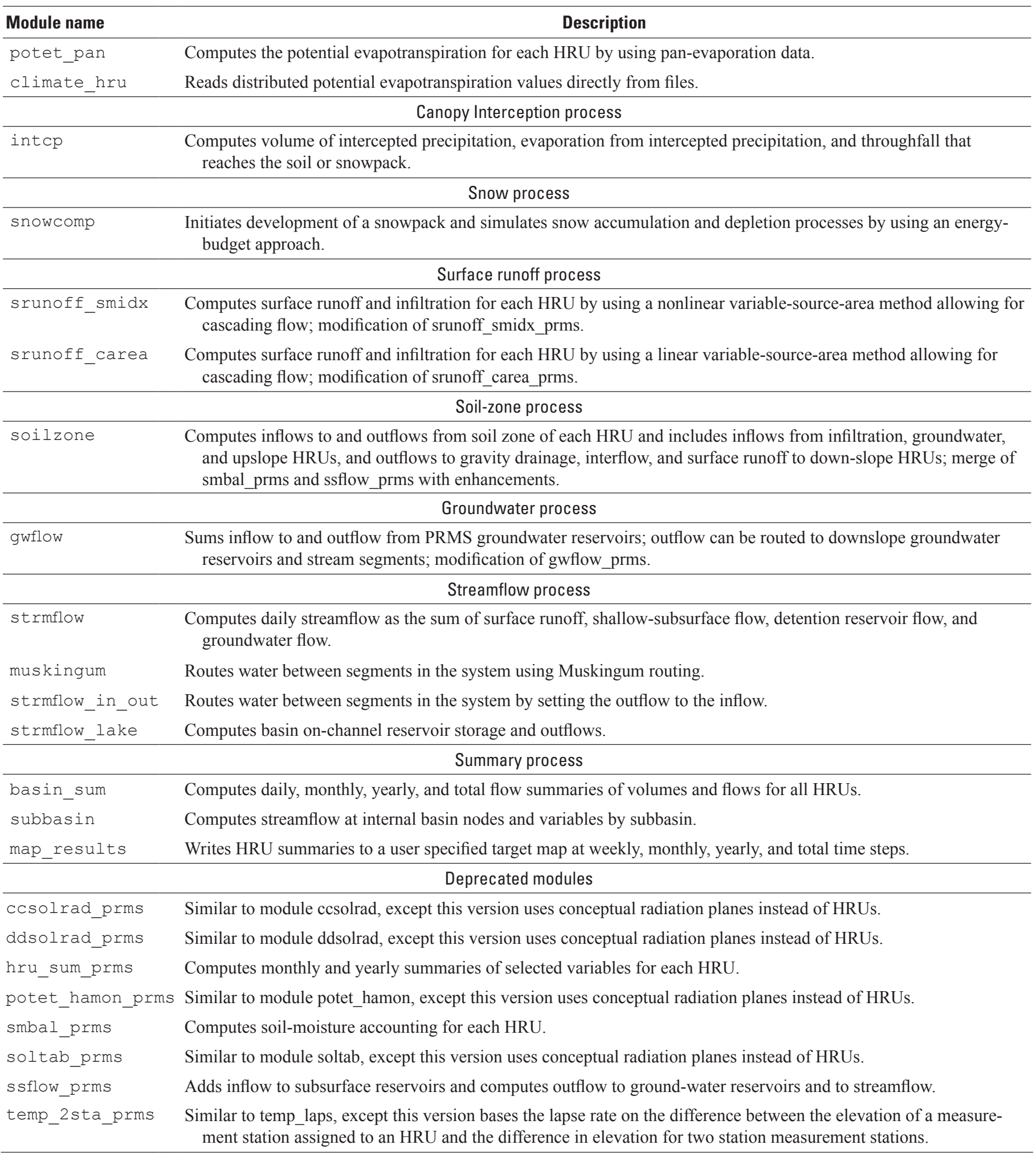




\section{Cascading Flow Process}

The Cascading Flow module (cascade) computes routing variables that are used by other modules to route lateral flow (surface runoff, interflow, and groundwater discharge) from upslope to downslope HRUs, lakes, or stream segments. Use of cascading flow allows surface runoff and interflow from an HRU to replenish soil-water storage deficits of downslope HRUs before being accounted as streamflow. The flow paths between groundwater reservoirs can be different than the surface-water flow paths. Because there is only one module to simulate this process, the user does not specify this selection in the Control File.

\section{Solar Table Process}

The Solar Table module (soltab) calculates a table of 366 (maximum number of days in a year) values of clear-sky solar radiation and daylight length for each HRU based on slope, aspect, and latitude. This module also computes values of clear-sky solar radiation at a horizontal surface at the model domain centroid for each day of the year. Because there is only one module to simulate this process, the user does not specify this selection in the Control File.

\section{Time Series Data Process}

The Time Series Data module (obs) determines the availability of the measured data for each time step specified in the Data File. Required measured data are (1) precipitation and (2) maximum and minimum air temperatures. Optional measured data, if specified in the Data File, could include solar radiation and streamflow. Because there is only one module to simulate this process, the user does not specify this selection in the Control File.

\section{Temperature Distribution Process}

The Temperature Distribution modules (temp_1sta, temp_laps, and temp_dist2) distribute maximum and minimum daily air temperatures to each HRU. The user must select a Temperature Distribution module by setting the control parameter temp_module in the Control File to a valid Temperature Distribution module name (table 2). Alternatively, a Combined Climate Distribution module (ide_dist or xyz_dist) or the Pre-Processed Climate Distribution module (climate_hru) can be selected as the Temperature Distribution process. If the user selects ide dist or xyz dist for the Temperature Distribution process, that module also must be selected as the Precipitation Distribution process.

\section{Precipitation Distribution Process}

The Precipitation Distribution modules (precip_1sta, precip_laps, and precip_dist2) distribute precipitation to each HRU. The user must select a Precipitation Distribution module by setting the control parameter precip module in the Control File to a valid Precipitation Distribution module name (table 2). Alternatively, a Combined Climate Distribution module (ide_dist or xyz_dist) or the PreProcessed Climate Distribution module (climate hru) can be selected as the Precipitation Distribution process. As stated above with the Temperature Distribution process, if the user selects ide_dist or xyz_dist for the Precipitation Distribution process, that module also must be selected as the Temperature Distribution process.

\section{Combined Climate Distribution Process}

The ide_dist and xyz_dist modules distribute maximum and minimum temperatures and precipitation to each HRU. To select one of these modules, the same module name must be selected for both the Temperature Distribution process and Precipitation Distribution process input by setting the control parameters temp_module and precip_module in the Control File (table 2).

The Climate-by-HRU (CBH) Distribution Module (climate_hru) provides methods to input daily, time-series climate values, pre-distributed to each HRU as an alternative to the use of climate distribution modules available in PRMSIV. Thus, it is possible to use any method to pre-process and distribute climate values to HRUs outside of a PRMS-IV simulation. For example, precipitation can be distributed from a time-series grid (such as from a general circulation model or radar data set) to each HRU with an area-weighted overlay between the precipitation grid map and HRU map. The types of climate values that can be read by the climate hru module are (1) daily precipitation, (2) maximum and minimum air temperature, (3) potential evapotranspiration, (4) solar radiation, (5) active transpiration, and (6) humidity. These values are read from separate climate-by-HRU (CBH) Files for each data type, one file for types 1, 3, 4, 5, and 6 and two for type 2. CBH Files are identical in format to the PRMS Data File (Markstrom and others, 2008, fig. A1-1). Any combination of these data types can be input to a simulation. Thus, one to six types and up to seven CBH files can be used. Data types not specified using CBH Files, are computed and distributed to each HRU using the selected climate distribution module. The user selects the climate_hru module by setting any of the control parameters temp_module, precip_module, solrad_module, transp_module, and et_module and the associated pathname of the CBH File(s) by setting the control parameters tmin_day, tmax_day, precip_day, swrad_day, transp_day, and potet_day, respectively, in the Control File. 


\section{Solar Radiation Distribution Process}

The Solar Radiation Distribution modules (ddsolrad and ccsolrad) distribute solar radiation to each HRU. These modules include algorithms for estimating solar radiation when measured solar-radiation data are not available. The climate_hru module can be used to input solar radiation directly from a file. The user must select a Solar Radiation Distribution module by setting the control parameter solrad module in the Control File to a valid Solar Radiation Distribution module name (table 2).

\section{Transpiration Period Process}

The Transpiration Period modules (transp_frost and transp tindex) determine whether the dominate vegetation in each HRU is actively transpiring. Alternatively, transpiration values can be pre-distributed to each HRU and input to PRMS-IV using the climate hru module that is described in the "Combined Climate Distribution Process" section in this report. The user must select a Transpiration Period module by setting the control parameter transp_module in the Control File to a valid Transpiration Period module name (table 2).

\section{Potential Evapotranspiration Process}

The Potential Evapotranspiration modules (potet hamon, potet_jh, potet_hs, potet_pt, potet_ penmon and potet_pan) calculate the amount of potential evapotranspiration in an HRU. The climate_hru module can be used to input potential evapotranspiration directly from a file. The user must select a Potential Evapotranspiration module by setting the control parameter et_module in the Control File to a valid Potential Evapotranspiration module name (table 2).

\section{Canopy Interception Process}

The Interception module (intcp) calculates the amount of rain and snow that is intercepted by vegetation, the amount of evaporation of intercepted rain and snow, and the amount of net rain and snow throughfall that reaches the soil or snowpack. Because there is only one module to simulate this process, the user does not specify this selection in the Control File.

\section{Snow Process}

The Snow module (snowcomp) simulates the initiation, accumulation, and depletion of a snowpack on each HRU. This module computes snowmelt, snowpack depth, density, liquid-water equivalent, free-water content, snowpack temperature, albedo, and cover area of each snowpack. Because there is only one module to simulate this process, the user does not specify this selection in the Control File.

\section{Surface Runoff Process}

The Surface Runoff modules (srunoff_smidx and srunoff_carea) partition snowmelt and net precipitation that reach the soil surface into soil infiltration or infiltration excess surface runoff on the pervious parts of each HRU. These modules also compute evaporation from the impervious parts of each HRU. These modules also compute evaporation, runoff, and seepage from surface depression storage. The user must select a Surface Runoff module by setting the control parameter srunoff_module in the Control File to a valid Surface Runoff module name (table 2).

\section{Soil-Zone Process}

The Soil-Zone module ( and all inflows and outflows in the soil zone for each HRU. Inflow to the soil zone includes the infiltration computed by the Surface Runoff module. Outflows from the soil zone include evapotranspiration, slow interflow, preferential flow, and saturation excess surface runoff. Absolute storage and changes in soil-zone storage are calculated by this module. The user must select the Soil-Zone module by setting the control parameter soilzone_module to soilzone (table 2).

\section{Groundwater Process}

The Groundwater module (gwflow) calculates groundwater storage and all inflows and outflows to and from the saturated zone for each HRU. Inflow to the saturated zone includes the recharge computed by the Soil-Zone module. Outflows from the saturated zone include the baseflow contribution to streamflow and groundwater flow out of the model domain that is not accounted for by streamflow. The absolute amount of storage and changes in storage in the saturated zone are also calculated by this module. Because there is only one module to simulate this process, the user does not specify this selection in the Control File.

\section{Streamflow Process}

The Streamflow modules (strmflow, muskingum, strmflow_in_out, and strmflow_lake) calculate total streamflow out of the model domain by summing the contributions to streamflow computed by the other modules. These contributions always include baseflow, interflow, and direct surface runoff. Depending on module configuration, they can also include other components of streamflow. Explicit streamflow routing may or may not be employed by a Streamflow module. The user must select a Streamflow module by setting the control parameter strmflow_module in the Control File to a valid Streamflow module name (table 2). 


\section{Summary Process}

The Summary modules (bas in sum, subbas in, and map_results) calculate water balances and generate various reports for a simulation. The Basin Summary module (bas in_sum) generates an overall water-balance report for the model domain. The Subbasin module (subbas in) calculates streamflow for groups of HRUs and area-weighted variables for specified subbasins. Finally, the Results Mapping module (map_results) aggregates (or disaggregates) simulated output from PRMS-IV into a different spatiotemporal resolution for input to other simulation models. All of the files created by the Summary Process modules are described in more detail in the "Output Files" section in this report.

\section{Operational Sequence}

Execution of the PRMS-IV simulation consists of a sequence of twelve stages (fig. 5):

1. The simulation starts by reading the Control File and assigning the specified modules to their respective processes and computation options. Collectively, the modules that have been assigned in this way are referred to as the "active modules."

2. PRMS-IV executes the "declare" function of all active modules in the proper sequence. This step allocates arrays and defines the actual parameters and variables used in the simulation by the active modules.

3. Parameter values are read from the Parameter File. If values are not specified for a parameter in the Parameter File, default values are assigned.

4. PRMS-IV executes the "initialization" function of all active modules in the proper sequence. State and flux variables for active modules are initialized and parameter values checked for validity.

5. The time-step loop begins the "run" function.

6. For each time step, the input variables, which may include precipitation, air temperature, and measured streamflow values, are read from the Data File (this is the Time Series Data Process).

7. PRMS-IV executes all active modules in the proper sequence beginning with distribution of climate and energy information to the HRUs (includes the Temperature Distribution, Precipitation Distribution, Combined Climate Distribution, Solar Radiation Distribution, Transpiration Period, and Potential Evapotranspiration Processes). This information is used to drive the simulation of the selected hydrologic processes.
8. The HRU states and fluxes on the land surface are computed by the modules that simulate the surface processes (includes the Canopy Interception, Snow, and Surface Runoff Processes). Then the remaining HRU states and fluxes are computed by the modules that simulate the sub-surface processes (includes the Soil-Zone, Groundwater Process).

9. The stream network processes are computed that simulate streamflow and lake dynamics processes (includes the Streamflow Process).

10. After all computations are completed for a time step, results are summarized and written to output files (Summary Process).

11. The input data for the next time step are read and the steps 6-10 are repeated until the last time step is completed.

12. All final results are written and output files are closed.

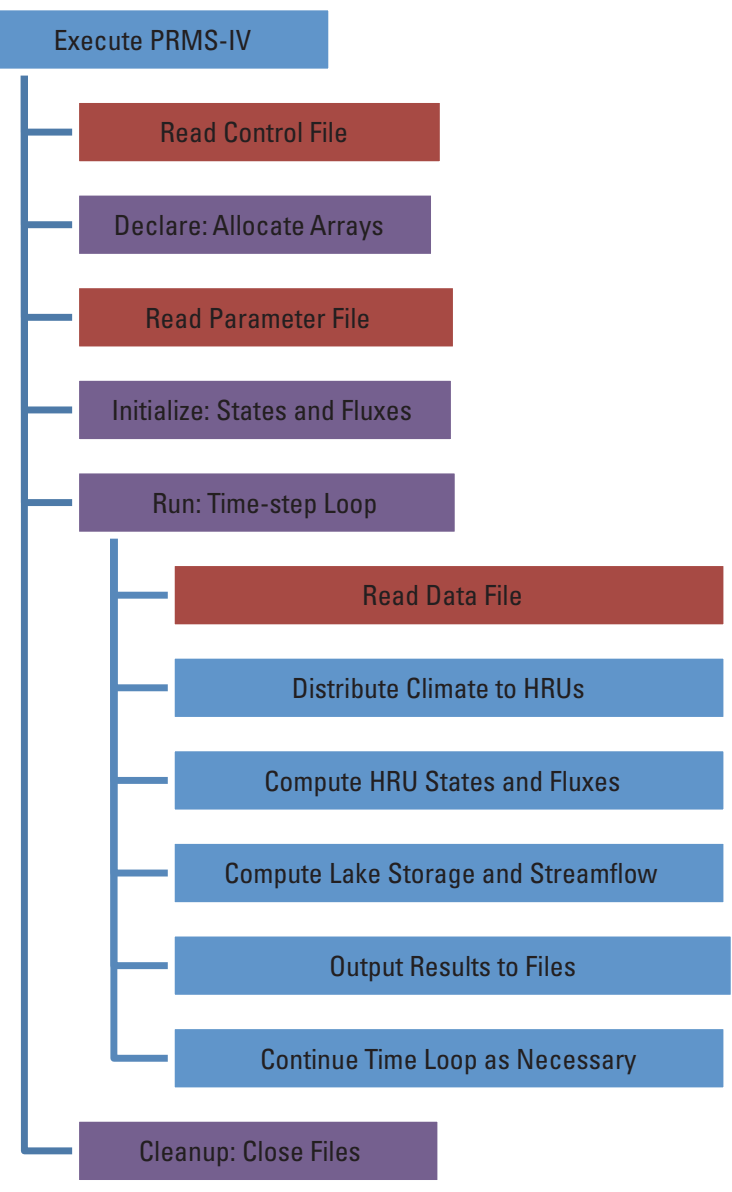

Figure 5. Computational sequence of PrecipitationRunoff Modeling System (PRMS-IV). 


\section{Input and Output Files}

Input data for a PRMS-IV simulation are specified in several files that must be prepared prior to simulation. Output data from a PRMS-IV simulation can be written to several files. The names, locations, and in some cases, formats of these files are specified by the user. The input and output files for a PRMS-IV simulation are described below.

\section{Input Files}

Three input files are required for a PRMS-IV simulation. These are the Control File, the Data File, and the Parameter File. A fourth type of input file, Climate by HRU (CBH) file(s) are required if the climate_hru module has been specified for any process. Brief descriptions of each input file follow; detailed descriptions of each input file are provided in Appendix 2.

The Control File contains all of the control parameters that PRMS-IV uses during the course of the simulation. There are five basic types of control parameters specified in this file: (1) those related to model execution, (2) those related to model input, (3) those related to model output, (4) those related to initial conditions, and (5) those related to specification of the active modules. Specifically, the Control File is used to specify input and output file names, content of the output files, simulation starting and ending dates, and the active modules.

The Data File contains measured time-series data used in a PRMS-IV simulation. These input data may include daily precipitation, maximum and minimum air temperatures, solar radiation, pan evaporation, measured streamflow, humidity, wind speed, and snowpack-water equivalent. At least one time-series must be specified. Time series of daily precipitation and maximum and minimum air temperatures are required for a simulation unless this information is input using $\mathrm{CBH}$ files.

The Parameter File contains the values of the parameters that are specified for each module that do not change during a simulation. This file also is used to specify the dimensions of the arrays for the parameters and variables that are specified in both the Parameter and Data Files.

The CBH files contain the time series of values for each HRU, for a particular process, that are read in as input during the simulation.

\section{Output Files}

Four output files can be generated in a PRMS-IV simulation: the Water-Budget File, the Statistic Variables File, the Animation File, and the Map Results File. Brief descriptions of each output file follow; detailed descriptions of each output file are provided in Appendix 2.

The Water-Budget File provides a summary table of the water budget for a PRMS-IV simulation. Three types of summary tables are available. The first is a listing of the measured and simulated flow. The second is a table of water-balance computations that includes the area-weighted average of net precipitation, evapotranspiration from all sources, storage in all reservoirs, and the simulated and measured streamflows. The third is a detailed summary, including several important states and fluxes. Any of the three types of summary tables may be specified in any combination of the available time increments - daily, monthly, yearly, or total for the simulation. Errors in the overall water budget also are reported in this file.

The Statistic Variables File is a text file that provides selected variables as time-series output. It has a similar format to the Data File used for model input. This file can be used with external visualization and statistics programs.

Animation Files are text files that provide selected variable output as time series of spatial arrays. These files can be used with GIS or map-based animation programs.

Map Results Files are text files that provide selected variable output as time series of spatial arrays that have been mapped to alternative spatial and temporal resolutions. These files can be used to loosely couple PRMS-IV to other simulation programs.

\section{Summary}

This report documents PRMS-IV, an updated version of the deterministic, distributed-parameter, physical-process hydrologic model commonly called the Precipitation-Runoff Modeling System (PRMS). The PRMS-IV simulates the processes of the hydrologic cycle, including evaporation, transpiration, runoff, infiltration, and interflow estimated by balancing energy and mass budgets of the plant canopy, snowpack, and soil zone on the basis of distributed climate information (temperature, precipitation, and solar radiation). To ensure that mass is conserved, hydrologic water budgets of the model domain, at temporal scales ranging from days to centuries are computed. The modular design of PRMS-IV facilitates integration with other models used for natural-resource management and other scientific disciplines.

\section{Acknowledgments}

Support for the PRMS-IV version was provided through the USGS National Research Program and the Office of Surface Water. The authors thank George Leavesley and Linda Stannard (retired, USGS National Research Program, Lakewood, Colorado) for their work on previous versions of PRMS. The authors also thank Georgina King, (HydroMetrics Water Resource, Inc., Oakland, California) and Larry G. Schneider (USGS, San Diego, California) for their contribution of figures used in this report. The technical reviewers of this report were Paul M. Barlow (USGS, Northborough, Massachusetts), John C. Risley (USGS, Portland, Oregon), Katherine Chase (USGS, Helena, Montana) and Rheannon Hart (USGS, Little Rock, Arkansas). We appreciate their thorough reviews and comments that improved greatly the quality of this report. 


\section{References Cited}

Ahearn, E.A., and Bjerklie, D.M., 2010, Connecticut Highlands Technical Report-Documentation of the Regional Rainfall-Runoff Model: U.S. Geological Survey OpenFile Report 2010-1187, 43 p., at http://pubs.usgs.gov/ of $/ 2010 / 1187 /$.

Barrett, A.P., Leavesley, G.H., Viger, R.L., Nolin, A.W., and Clark, M.P., 2000, A comparison of satellite-derived and modelled snow-covered area for a mountain drainage basin, in Owe, Manfred, Brubaker, Kaye, Ritchie, Jerry, and Rango, Albert, Remote sensing and hydrology: International Association of Hydrologic Sciences (IAHS) publication no. 267 , p. 569-573.

Battaglin, W.A., Hay, L.E., and Markstrom, S.L., 2011, Simulating the potential effects of climate change in two Colorado Basins and at two Colorado ski areas: Earth Interactions, v. 15, no. 22, p.1-23.

Battaglin, W.A., Hay, L.E., Parker, R.S., and Leavesley, G.H., 1993, Applications of GIS for modeling the sensitivity of water resources to alterations in climate in the Gunnison River basin, Colorado: Water Resources Bulletin v. 25, no. 6 , p. 1,021-1,028.

Berris, S.N., Hess, G.W., and Bohman, L.R., 2001, River and reservoir operation model, Truckee River basin, California and Nevada, 1998: U.S. Geological Survey WaterResources Investigations Report 01-4017, 138 p.

Bjerklie, D.M., Starn, J.J., and Tamayo, Claudia, 2010, Estimation of the effects of land use and groundwater withdrawals on streamflow for the Pomperaug River, Connecticut: U.S. Geological Survey Scientific Investigations Report 2010-5114, 81 p., at http://pubs.usgs.gov/sir/2010/5114/.

Bjerklie, D.M., Trimbley, T.J., and Viger, R.J., 2011, Simulations of historical and future trends in snowfall and groundwater recharge for basins draining to Long Island Sound: Earth Interactions, v. 15, no. 34, p. 1-35.

Bower, D.E., 1985, Evaluation of the Precipitation-Runoff Modeling System, Beaver Creek, Kentucky: U.S. Geological Survey Scientific Investigations Report 84-4316, 39 p.

Boyle, D.P., Lamorey, G.W., Huggins, A.W., 2006, Application of a hydrologic model to assess the effects of cloud seeding in the Walker River basin, Nevada: Journal of Weather Modification, v. 38, p. 66-67.

Brendecke, C.M., Laiho, D.R., and Holden, D.C., 1985, Comparison of two daily streamflow simulation models of an alpine watershed: Journal of Hydrology, v. 77, p. 171-186.
Brendecke, C.M., and Sweeten, J.G., 1985, A simulation model of Boulder's alpine water supply: Annual Meeting of the Western Snow Conference, 53rd, Boulder, Colorado, Proceedings, p. 63-71.

Carey, W.P., and Simon, Andrew, 1984, Physical basis and potential estimation techniques for soil erosion parameters in the Precipitation-Runoff Modeling System (PRMS): U.S. Geological Survey Water-Resources Investigations Report 84-4218, 32 p.

Cary, L.E., 1984, Application of the U.S. Geological Survey's Precipitation-Runoff Modeling System to the Prairie Dog Creek basin, southeastern Montana: U.S. Geological Survey Water-Resources Investigations Report 84-4178, 98 p.

Cary, L.E., 1991, Techniques for estimating selected parameters of the U.S. Geological Survey's Precipitation-Runoff Modeling System in eastern Montana and northeastern Wyoming: U.S. Geological Survey Water-Resources Investigations Report 91-4068, 39 p.

Chow, V.T., Maidment, D.R., and Mays, L.W., 1988, Applied hydrology: McGraw-Hill, Inc., New York, 572 p.

Christiansen, D.E., Markstrom, S.L., and Hay, L.E., 2011, Impacts of climate change on growing season in the United States: Earth Interactions, v. 15, no. 33, p. 1-17.

Clark, M.P., and Hay, L.E., 2000, Use of atmospheric forecasts in hydrologic models - Part one-Errors in output from the NCEP atmospheric forecast model, in Kane, D.L., ed., Water resources in extreme environments: Middleburg, Va., American Water Resources Association, p. 215-220.

Clark, M.P., and Hay, L.E., 2004, Use of medium-range numerical weather prediction model output to produce forecasts of streamflow: Journal of Hydrometeorology, v. 5, no. 1, p. 15-32.

Dettinger, M.D., Cayan, D.R., Meyer, M.K., and Jeton, A.E., 2004, Simulated hydrologic responses to climate variations and change in the Merced, Carson, and American River basins, Sierra Nevada, California, 1900-2099: Climatic Change, v. 62, p. 283-317.

Duan, Qingyun, Schaake, J.C., Andreassian, Vazken, Franks, Stewart, Goteti, Gopi, Gupta, H.V., Gusev, Y.M., Habets, Florence, Hall, Alan, Hay, L.E., Hogue, T.S., Huang, M., Leavesley, G.L., Liang, X., Nasonova, O.N., Noilhan, Joel, Oudin, L., Sorooshian, Soroosh, Wagener, Thorsten, and Wood, E.F., 2006, Model Parameter Estimation Experiment (MOPEX) - An overview of science strategy and major results from the second and third workshops: Journal of Hydrology, v. 320, no. 1-2, p. 3-17. 
Dudley, R.W., 2008, Simulation of the quantity, variability, and timing of streamflow in the Dennys River Basin, Maine, by use of a precipitation-runoff watershed model: U.S. Geological Survey Scientific Investigations Report 2008-5100, 44 p., at http://pubs.usgs.gov/sir/2008/5100/.

Dressler, K.A., Leavesley, G.H., Bales, R.C., and Fassnacht, S.R., 2006, Evaluation of gridded snow water equivalent and satellite snow cover products for mountain basins in a hydrologic model: Hydrological Processes, v. 20, no. 4, p. 673-688.

Ely, D.M., 2006, Analysis of sensitivity of simulated recharge to selected parameters for seven watersheds modeled using the precipitation-runoff modeling system: U.S. Geological Survey Scientific Investigations Report 2006-5041, 21 p., at http://pubs.usgs.gov/sir/2006/5041/.

Emerson, D.G., 1991, Documentation of a heat and water transfer model for seasonally frozen soils with application to a precipitation-runoff model: U.S. Geological Survey Open-File Report 91-462, 92 p.

Flügel, W.A., and Lüllwitz, Thomas, 1993, Using a distributed hydrologic model with the aid of GIS for comparative hydrological modelling of micro- and mesoscale catchments in the USA and Germany, in Wilkinson, W.B., ed., Macroscale modelling of the hydrosphere: International Association of Hydrologic Sciences (IAHS) publication no. 214, p. 59-66.

Fulp, T.J., Vickers, W.B., Williams, Bruce, and King, D.L., 1995, Decision support for water resources management in the Colorado River region, in Ahuja, Laj, Leppert, J., Rojas, Ken, and Seely, E., eds., Workshop on computer applications in water management, Fort Collins, Colo., May 23-25, 1995, Proceedings: Fort Collins, Colo., Colorado State University Water Resources Research Institute, p. 24-27.

Gibson, C.A., Meyer, J.L., Poff, N.L., Hay, L.E., and Georgakakos, A.P., 2005, Flow regime alterations under changing climate in two river basins-Implications for freshwater ecosystems: River Research and Applications, v. 21, p. 849-864.

Hamon, W.R., 1961, Estimating potential evapotranspiration: Proceedings of the American Society of Civil Engineers, Journal of the Hydraulic Division, v. 87, no. HY3, p. $107-120$.

Hargreaves, G.H., and Samani, Z.A., 1982, Estimating potential evapotranspiration: Journal of Irrigation and Drainage Engineering, v. 108, no. 3, September 1982, p. 225-230.

Hay, L.E., Battaglin, W.A., Parker, R.S., and Leavesley, G.H., 1993, Modeling the effects of climate change on water resources in the Gunnison River basin, Colorado, in Goodchild, M.F., Parks, B.O., and Steyaert, L.T., eds., Environmental modeling with GIS: Oxford Univiversity Press, p. $173-181$.
Hay, L.E., and Clark, M.P., 2003, Use of statistically and dynamically downscaled atmospheric model output for hydrologic simulations in three mountainous basins in the western United States: Journal of Hydrology, v. 282, p. 56-75.

Hay, L.E., Clark, M.P., and Leavesley, G.H., 2000, Use of atmospheric forecasts in hydrologic models - Part twoCase study in Kane, D.L., ed., Water Resources in Extreme Environments: Middleburg, Va., American Water Resources Association, p. 221-226.

Hay, L.E., Clark, M.P., Pagowski, Mariusz, Leavesley, G.H., and Gutowski, W.J., Jr., 2006, One-way coupling of an atmospheric and a hydrologic model in Colorado: Journal of Hydrometeorology, v. 7, p. 569-589.

Hay, L.E., Clark, M.P., Wilby, R.L., Gutowski, W.J., Leavesley, G.H., Pan, Zaitao, Arritt, R.W., and Takle, E.S., 2002, Use of regional climate model output for hydrologic simulations: Journal of Hydrometeorology, v. 3, p. 571-590.

Hay, L.E., Leavesley, G.H., and Clark, M.P., 2006, Use of remotely sensed snow covered area in watershed model calibration for the Sprague River, Oregon, in Joint 8th Federal Interagency Sedimentation Conference and 3rd Federal Interagency Hydrologic Modeling Conference, Reno, Nev., April 2-6, 2006, Proceedings: Advisory Committee on Water Information, accessed August 17, 2011, at http://acwi.gov/hydrology/mtsconfwkshops/conf_ proceedings/3rdFIHMC/third_fihmc_nevada-2006.pdf.

Hay, L.E., Leavesley, G.H., Clark, M.P., Markstrom, S.L., Viger, R.J., and Umemoto, M., 2006, Step-wise, multipleobjective calibration of a hydrologic model for a snowmelt-dominated watershed: Journal of American Water Resources, v. 42, no. 4, p. 877-890.

Hay, L.E., Markstrom, S. L., and Ward-Garrison, C.D., 2011, Watershed-scale response to climate change through the 21st century for selected basins across the United States: Earth Interactions, v. 15, no. 17, p. 1-37.

Hay, L.E., and McCabe, G.J, 2002, Spatial variability in waterbalance model performance in the conterminous United States: Journal of American Water Resources Association, v. 38 , p. $847-860$.

Hay, L.E., and Umemoto, Makiko, 2007, Multiple-objective stepwise calibration using Luca: U.S. Geological Survey Open-File Report 2006-1323, 25 p.

Hay, L.E., Wilby, R.L., and Leavesley, G.H., 2000, A comparison of delta change and downscaled GCM scenarios for three mountainous basins in the United States: Journal of American Water Resources Association, v. 36, p. 387-397. 
Hejl, H.R., 1989, Application of the Precipitation-Runoff Modeling System to the Ah-Shi-Sle-Pah Wash watershed, San Juan County, New Mexico: U.S. Geological Survey Water-Resources Investigations Report 88-4140, 36 p.

Hunt, R.J., and Steuer, J.J., 2001, Evaluating the effects of urbanization and land-use planning using ground-water and surface-water models: U.S. Geological Survey Fact Sheet 102-01, 4 p.

Hutchinson, N.E., 1975, Watstore-National water data storage system of the U.S. Geological Survey-User's Guide: U.S. Geological Survey Open-File Report 75-426, 791 p.

Jensen, M.E., and Haise, H.R., 1963, Estimating evapotranspiration from solar radiation: Proceedings of the American Society of Civil Engineers, Journal of Irrigation and Drainage, v. 89 , p. $15-41$.

Jeton, A.E., 1999, Precipitation-runoff simulations for the Lake Tahoe Basin, California and Nevada: U.S. Geological Survey Water-Resources Investigations Report 99-4110, $61 \mathrm{p}$.

Jeton, A.E., 2000, Precipitation-runoff simulations for the upper part of the Truckee River Basin, California and Nevada: U.S. Geological Survey Water-Resources Investigations Report 99-4282, 41 p.

Jeton, A.E., Dettinger, M.D., and Smith, J.L., 1996, Potential effects of climate change on streamflow, eastern and western slopes of the Sierra Nevada, California and Nevada: U.S. Geological Survey Water-Resources Investigations Report 95-4260, 44 p.

Jeton, A.E., and Maurer, D.K., 2007, Precipitation and runoff simulations of the Carson Range and Pine Nut Mountains, and updated estimates of ground-water inflow and the ground-water budget for basin-fill aquifers of Carson Valley, Douglas County, Nevada, and Alpine County, California: U.S. Geological Survey Scientific Investigations Report 2007-5205, 56 p.

Kidd, R.E., and Bossong, C.R., 1987, Application of the precipitation-runoff model in the Warrior Coal Field, Alabama: U.S. Geological Survey Water-Supply Paper 2036, 42 p.

Koczot, K.M., Jeton, A.E., McGurk, B.J., and Dettinger, M.D., 2005, Precipitation-runoff processes in the Feather River Basin, northeastern California, with prospects for streamflow predictability, water years 1971-97: U.S. Geological Survey Scientific Investigations Report 2004-5202, 82 p.

Koczot, K.M., Markstrom, S.L., and Hay, L.E., 2011, Effects of baseline conditions on the simulated hydrologic response to projected climate change: Earth Interactions, v. 15, no. 27 , p. $1-23$.
Kuhn, Gehard, 1989, Application of the U.S. Geological Survey's Precipitation-Runoff Modeling System to Williams Draw and Bush Draw basins, Jackson County, Colorado: U.S. Geological Survey Water-Resources Investigations Report 88-4013, 38 p.

Kuhn, Gehard, and Parker, R.S., 1992, Transfer of watershed-model parameter values to noncalibrated basins in the Gunnison River Basin, Colorado, in Managing water resources during global change- AWRA 28th Annual Conference and Symposium: Middleburg, Va., American Water Resources Association, p. 741-750. [Conference held in Reno, Nevada, November 1-5, 1992]

Laenen, Antonius, and Risley, J.C., 1997, Precipitation-runoff and streamflow-routing models for the Willamette River Basin, Oregon: U.S. Geological Survey Water-Resources Investigations Report 95-4284, $70 \mathrm{p}$.

Leavesley, G.H., 1973, A mountain watershed simulation model: Fort Collins, Colo., Colorado State University, Ph.D. dissertation, $174 \mathrm{p}$.

Leavesley, G.H., 1989, Problems in snowmelt runoff modeling for a variety of physiographic and climatic conditions: Hydrological Sciences, v. 34, no. 6, p. 617-634.

Leavesley, G.H., 1999a, Assessment of the impacts of climate variability and change on the hydrology of North America, chap. 4, in van Dam, J.C., ed., Impacts of climate change and climate variability on hydrological regimes: Cambridge University Press, UNESCO International Hydrology Series, p. 36-51.

Leavesley, G.H., 1999b, Overview of models for use in the evaluation of the impacts of climate change on hydrology, chap. 8 of van Dam, J.C., ed., Impacts of climate change and climate variability on hydrological regimes: Cambridge University Press, UNESCO International Hydrology Series, p. 107-122.

Leavesley, G.H., 2002, The Devils Lake basin wetlands model, in Vining, K., Simulation of streamflow and wetlands storage, Starkweather Coulee subbasin, North Dakota, water years 1981-98: Water-Resources Investigations Report 02-4113, p. 26-28.

Leavesley, G.H., 2005a, Rainfall-runoff modeling for integrated basin management, in Anderson, M.G., ed., Encyclopedia of hydrological sciences: J.W. Wiley, p. 2001-2006.

Leavesley, G.H., 2005b, Coupled models for the hydrological cycle-Integrating atmosphere, biosphere, and pedosphere, in Bronstert, Axel, Carrera, Jesus, Kabat, Pavel, and Luetkemeier, Sabine eds., Coupled models for the hydrological cycle: Berlin, Springer, $356 \mathrm{p}$. 
Leavesley, G.H. and Hay, L.E., 1998, The use of coupled atmospheric and hydrological models for water-resources management in headwater basins, in Kovar, Karel, Tappeiner, Ulrike, Peters, N.E., and Craig, R.G., eds., Hydrology, water resources and ecology in headwaters: International Association of Hydrologic Sciences (IAHS) Publication no. 248, p. 259-265.

Leavesley, G.H., Hay, L.E., Viger, R.J., and Markstrom, S.L., 2003, Use of a priori parameter-estimation methods to constrain calibration of distributed-parameter modes, in Duan, Qingyun, Gupta, H.V., Sorooshian, Soroosh, Rousseau, A.N., and Turcotte, Richard, eds., Calibration of watershed models: American Geophysical Union; Water, Science and Application, v. 6, p. 255-266.

Leavesley, G.H., Lichty, R.W., Troutman, B.M., and Saindon, L.G., 1981, A precipitation-runoff modeling system for evaluating the hydrologic impacts of energy-resource development, in Annual Meeting of the Western Snow Conference, 49, St. George, Utah, April 14-16, 1981, Proceedings: Soda Springs, Calif., Western Snow Conference, p. 65-76.

Leavesley, G.H., Markstrom, S.L., Viger, R.J., Coffelt, J.L., and Livingston, R.K., 2002, A decision support system for impact analysis of wildland fires: U.S. Geological Survey Open-File Report 02-0011, p. 86.

Leavesley, G.H., Lichty, R.W., Troutman, B.M., and Saindon, L.G., 1983, Precipitation-runoff modeling system-User's manual: U.S. Geological Survey Water Resources Investigation Report 83-4238, 207 p.

Leavesley, G.H., Lusby, G.C., and Lichty, R.W., 1989, Infiltration and erosion characteristics of selected tephra deposits from the 1980 eruption of Mount St. Helens, Washington: Hydrological Sciences Journal, v. 34, no. 3, p. 339-353.

Leavesley, G.H., Markstrom, S. L., Restrepo, P. J., and Viger, R. J., 2002, A modular approach to addressing model design, scale, and parameter estimation issues in distributed hydrological modeling: Hydrologic Processes, v. 16, p. 173-187.

Leavesley, G.H., Markstrom, S.L., Viger, R.J., and Hay, L.E., 2005, USGS Modular Modeling System (MMS) Precipitation-Runoff Modeling System (PRMS) MMSPRMS, in Singh, V.P., and Frevert, D.K., eds., Watershed models: Boca Raton, Fla., CRC Press, p. 159-177.

Leavesley, G.H., Restrepo, P.J., Markstrom, S.L., Dixon, M.J., and Stannard, L.G., 1996, The Modular Modeling System (MMS) -User's manual: U.S. Geological Survey Open-File Report 96-151, 142 p.

Leavesley, G.H., and Stannard, L.G., 1995, The precipitationrunoff modeling system-PRMS, in Singh, V.P., ed., Computer models of watershed hydrology: Highlands Ranch, Colo., Water Resources Publications, p. 281-310.
Lee, K.K., and Risley, J.C., 2001, Estimates of ground-water recharge, base flow, and stream reach gains and losses in the Willamette River Basin, Oregon: U.S. Geological Survey Water-Resources Investigations Report 01-4215, 52 p.

Markstrom, S.L., and Hay, L.E, 2009, Integrated watershed scale response to climate change for selected basins across the United States: Water Resources Impact, v. 11, no. 2, p. 8-10.

Markstrom, S.L., Hay, L.E., Ward-Garrison, C.D., Risley, J.C., Battaglin, W.A., Bjerklie, D.M., Chase, K.J., Christiansen, D.E. Dudley, R.W., Hunt, R.J., Koczot, K.M., Mastin, M.C., Regan, R.S., Viger, R.J., Vining, K.C., and Walker, J.F., 2012, Integrated watershed scale response to climate change for selected basins across the United States: U.S. Geological Survey Scientific Investigations Report 2011-5077, 143 p., at $h t t p: / / p u b s . u s g s . g o v /$ sir/2011/5077/.

Markstrom, S.L., King, D.K., and Davidson, Paul, 2001, Decision support system for the Upper Gunnison River Basin, Colorado, in Decision support systems for water resources management, Snowbird, Utah, June 2001, Proceedings: American Water Resources Association, p. 389-394.

Markstrom, S.L., and Koczot, K.M., 2008, User's manual for the Object User Interface (OUI) - An environmental resource modeling framework: U.S. Geological Survey Open-File Report 2008-1120, 39 p., at http://pubs.usgs.gov/ of/2008/1120/.

Markstrom, S.L., Niswonger, R.G., Regan, R.S., Prudic, D.E., and Barlow, P.M., 2008, GSFLOW-Coupled ground-water and surface-water flow model based on the integration of the Precipitation-Runoff Modeling System (PRMS) and the Modular Ground-Water Flow Model (MODFLOW-2005): U.S. Geological Survey Techniques and Methods 6-D1, $240 \mathrm{p}$.

Mastin, M.C., 2009, Watershed models for decision support for inflows to Potholes Reservoir: U.S. Geological Survey Scientific Investigations Report 2009-5081, 54 p., at http:// pubs.usgs.gov/sir/2009/5081/.

Mastin, M.C., Chase, K.J., and Dudley, R.W., 2011, Changes in spring snowpack for selected basins in the United States for different climate-change scenarios: Earth Interactions, v. 15 , no. 23 , p. $1-18$.

Mastin, M.C., and Vaccaro, J.J., 2002a, Documentation of Precipitation Runoff Modeling System modules for the Modular Modeling System modified for the Watershed and River Systems Management Program: U.S. Geological Survey Open-File Report 2002-362, 5 p.

Mastin, M.C., and Vaccaro, J.J., 2002b, Watershed models for decision support in the Yakima River Basin, Washington: U.S. Geological Survey Open-File Report 2002-404, 47 p. 
McCabe, G.J., and Hay, L.E., 1995, Hydrological effects of hypothetical climate change in the East River Basin, Colorado, USA: Hydrological Sciences Journal, v. 40, no. 3, p. 303-318.

Milly, P.C.D., and Dunne, K.A., 2011, On the hydrologic adjustment of climate-model projections-The potential pitfall of potential evapotranspiration: Earth Interactions, v. 15 , no. 1 , p. 1-14.

Monteith, J.L., 1965, Evaporation and the environment, in The state and movement of water in living organisms, XIXth Symposium, Swansea, Wales: Cambridge University Press, p. 205-234.

Nakama, L.Y., and Risley, J. C., 1993, Use of a rainfall-runoff model for simulating effects of forest management on streamflow in the East Fork Lobster Creek Basin, Oregon Coast Range: U.S. Geological Survey Water-Resources Investigations Report 93-4040, 47 p.

Norris, J.M., 1986, Application of the Precipitation-Runoff Modeling System to small basins in the Parachute Creek basin, Colorado: U.S. Geological Survey Water-Resources Investigations Report 86-4115, 38 p.

Norris, J.M., and Parker, R.S., 1985, Calibration procedure for a daily flow model of small watersheds with snowmelt runoff in the Green River coal region of Colorado: U.S. Geological Survey Water-Resources Investigations Report 83-4263, $32 \mathrm{p}$.

Olson, S.A., 2002, Flow-frequency characteristics of Vermont streams: U.S. Geological Survey Water-Resources Investigations Report 2002-4238, 47 p.

Parker, R.S., and Norris, J.M., 1989, Simulation of streamflow in small drainage basins in the southern Yampa River Basin, Colorado: U.S. Geological Survey Water-Resources Investigations Report 88-4071, $47 \mathrm{p}$.

Penman, H.L., 1948, Natural evaporation from open water, bare soil and grass: Proceedings of the Royal Society of London, series A, v. 193, no. 1032, p. 120-145.

Priestley, C.H.B, and Taylor, R.J, 1972, On the assessment of surface heat flux and evaporation using large-scale parameters: Monthly Weather Review, v. 100, no. 2, p. 81-92.

Puente, Celso, and Atkins, J.T., 1989, Simulation of rainfallrunoff response in mined and unmined watersheds in coal areas of West Virginia: U.S. Geological Survey WaterSupply Paper 2298, 48 p.

Rankl, J.G., 1987, Analysis of sediment production from two small semiarid basins in Wyoming: U.S. Geological Survey Water-Resources Investigations Report 85-4314, 27 p.
Reed, L.A., 1986, Verification of the PRMS sediment-discharge model, in Federal Interagency Sedimentation Conference, 4, Las Vegas, Calif., March 24-26, 1986, Proceedings: Federal Interagency Sedimentation Conference, v. II, p. 6-44-6-54.

Risley, J.C., 1994, Use of a precipitation-runoff model for simulating effects of forest management on stream flow in 11 small drainage basins, Oregon Coast Range: U.S. Geological Survey Water-Resources Investigations Report 93-4181, $61 \mathrm{p}$.

Risley, J.C., Moradkhani, Hamid, Hay, L.E., and Markstrom, S.L., 2011, Statistical comparisons of watershed-scale response to climate change in selected basins across the United States: Earth Interactions, v. 15, no. 14, p. 1-26.

Rivera-Santos, Jorge, 1990, Parameter estimation in conceptual precipitation-runoff models with emphasis on error analysis, in Tropical hydrology and Caribbean water resources, Proceedings of the International Symposium on Tropical Hydrology and Fourth Caribbean Islands Water Resources Congress, San Juan, Puerto Rico: American Water Resources Association, p. 91-100.

Ryan, Tom, 1996, Development and application of a physically based distributed parameter rainfall runoff model in the Gunnison River Basin: U.S. Bureau of Reclamation, Climate Change Response Program, 64 p.

Scott, A.G., 1984, Analysis of characteristics of simulated flows from small surface-mined and undisturbed Appalachian watersheds in the Tug Fork basin of Kentucky, Virginia, and West Virginia: U.S. Geological Survey WaterResources Investigations Report 84-4151, 169 p.

Stannard, L.G., and Kuhn, Gehard, 1989, Watershed modeling, in Britton, L.J., Anderson, C.L., Goolsby, D.A., and Van Haveren, B.P., eds., Summary of the U.S. Geological Survey and U.S. Bureau of Land Management National Coal-Hydrology Program, 1974-84: U.S. Geological Survey Professional Paper 1464, p. 120-125.

Steuer, J.J., and Hunt, R.J., 2001, Use of a watershed-modeling approach to assess hydrologic effects of urbanization, North Fork Pheasant Branch basin near Middleton, Wisconsin: U.S. Geological Survey Water-Resources Investigations Report 2001-4113, 49 p.

Troutman, B.M., 1985, Errors and parameter estimation in precipitation-runoff modeling: Water Resources Research, v. 21 , no. 8 , p. $1214-1222$.

Vaccaro, J.J., 1992, Sensitivity of groundwater recharge estimates to climate variability and change, Columbia Plateau, Washington: Journal of Geophysical Research, v. 97, no. D3, p. 2821-2833. 
Vaccaro, J.J., 2007, A deep percolation model for estimating ground-water recharge-Documentation of modules for the modular modeling system of the U.S. Geological Survey: U.S. Geological Survey Scientific Investigations Report 2006-5318, $30 \mathrm{p}$.

van Heeswijk, Marijke, 2006, Development of a precipitationrunoff model to simulate unregulated streamflow in the Salmon Creek Basin, Okanogan County, Washington: U.S. Geological Survey Scientific Investigations Report 20065274, 36 p., at http://pubs.usgs.gov/sir/2006/5274/.

Viger, R.J., Hay, L.E., Markstrom, S.L., Jones, J.W. and Buell, G.R., 2011, Hydrologic effects of urbanization and climate change on the Flint River Basin, Georgia: Earth Interactions, v. 15 , no. 20 , p. 1-25.

Viger, R.J., and Leavesley, G.H., 2007, The GIS Weasel user's manual: U.S. Geological Survey Techniques and Methods, book 6, chap. B4, 201 p., at http://pubs.usgs.gov/ tm/2007/06B04/.

Vining, K.C., 2002, Simulation of streamflow and wetland storage, Starkweather Coulee subbasin, North Dakota, water years 1981-98: U.S. Geological Survey Water-Resources Investigations Report 02-4113, 28 p.

Vining, K.C., 2004, Simulation of Runoff and Wetland Storage in the Hamden and Lonetree Watershed Sites Within the Red River of the North Basin, North Dakota and Minnesota: U.S. Geological Survey Scientific Investigations Report 2004-5168, 28 p.

Walker, J.F., Hay, L.E., Markstrom, S.L., and Dettinger, M.D., 2011, Characterizing climate-change impacts on the 1.5year flood flow in selected basins across the United StatesA probabilistic approach: Earth Interactions, v. 15, no. 18, p. $1-16$.

Wilby, R.L., Hay, L.E., Gutowski, W.J, Arritt, R.W., Takle, E.S., Pan, Zaitao, Leavesley, G.H., and Clark, M.P., 2000, Hydrological responses to dynamically and statistically downscaled climate model output: Geophysical Research Letters, v. 27, p. 1199-1202.
Wilby, R.L., Hay, L.E., and Leavesley, G.H., 1999, A comparison of downscaled and raw GCM output-Implications for climate change scenarios in the San Juan River basin, Colorado: Journal of Hydrology, v. 225, p. 67-91.

World Meteorological Organization, 1986, Intercomparison of models of snowmelt runoff: Geneva, World Meteorological Organization, Operational Hydrology Report no. 23, World Meteorological Organization Publication no. 646, 430 p.

Yeung, C.W., 2005, Rainfall-runoff and water-balance models for management of the Fena Valley Reservoir, Guam: U.S. Geological Survey Scientific Investigations Report 2004$5287,52 \mathrm{p}$.

Yates, D.N., Warner, T.T., Brandes, E.A., Leavesley, G.H., Sun, Juanzhen, Mueller, C.K., 2001, Evaluation of flashflood discharge forecasts in complex terrain using precipitation: Journal of Hydrologic Engineering, v. 6, no. 4, p. 265-274.

Yates, D.N., Warner, T.T., and Leavesley, G.H., 2000, Prediction of a flash flood in complex terrain, Part II-A comparison of flood discharge simulations using rainfall input from radar, a dynamic model, and an automated algorithmic system: Journal of Applied Meteorology, v. 39, no. 6, p. $815-825$. 



\section{Appendix 1. PRMS-IV Module Documentation}

\section{Contents}

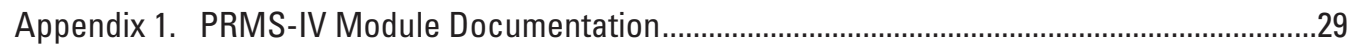

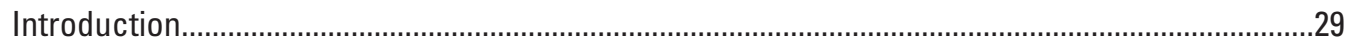

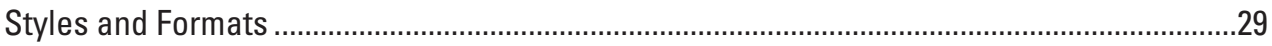

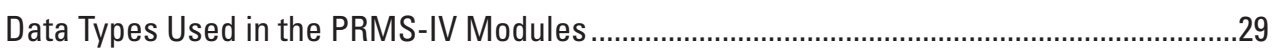

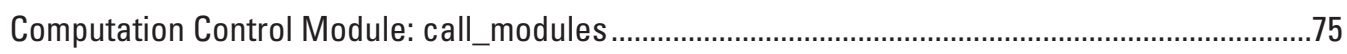

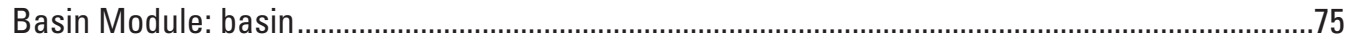

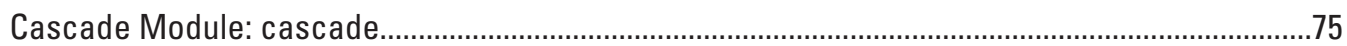

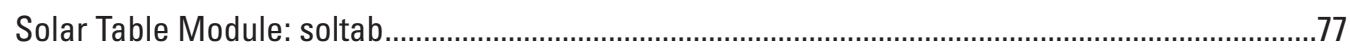

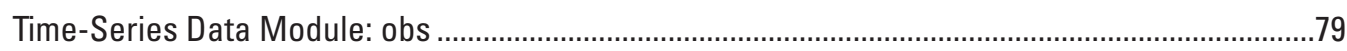

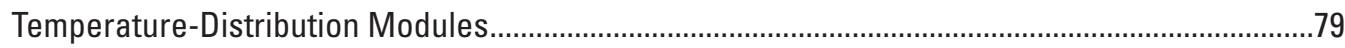

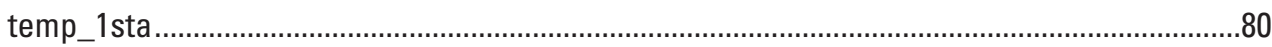

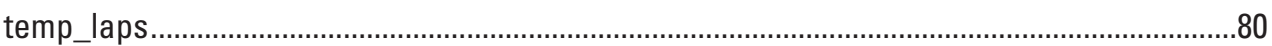

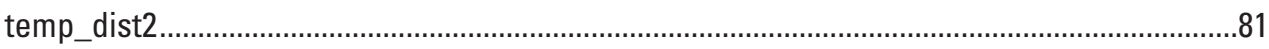

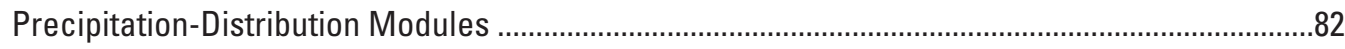

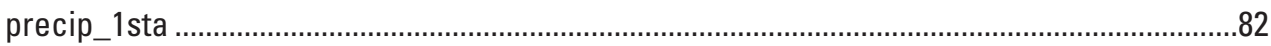

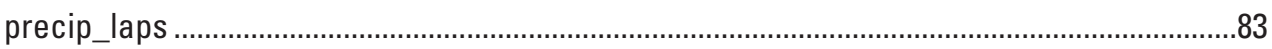

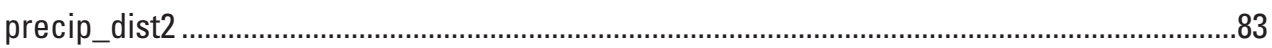

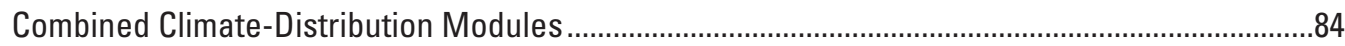

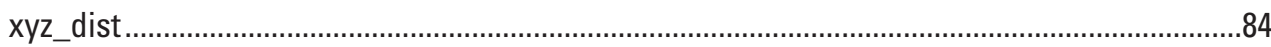

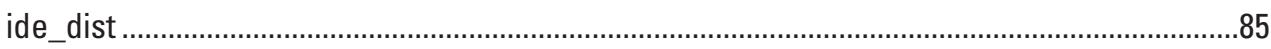

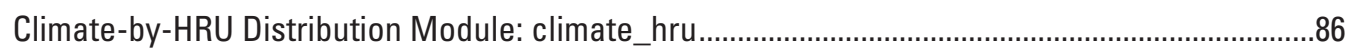

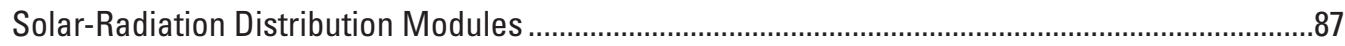

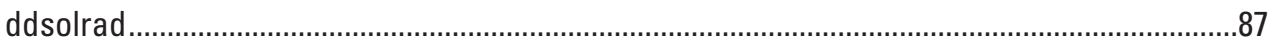

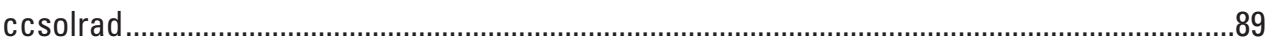

Transpiration Period Modules ................................................................................................ 89

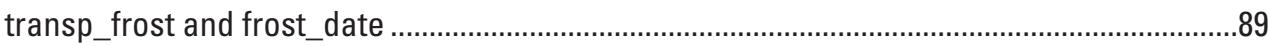

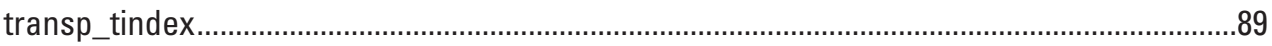

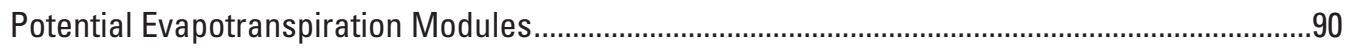

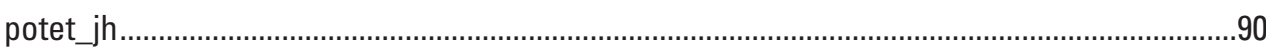

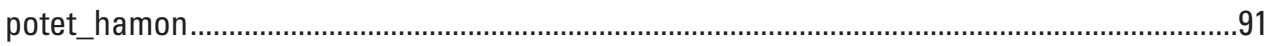

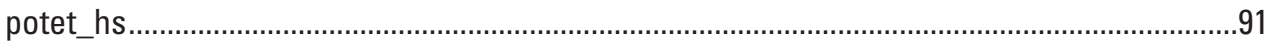

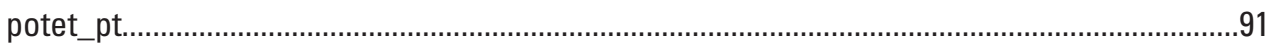

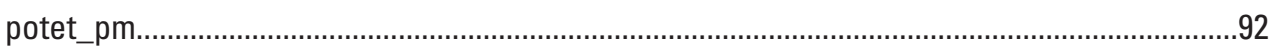

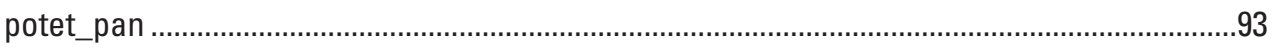

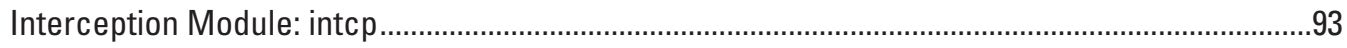

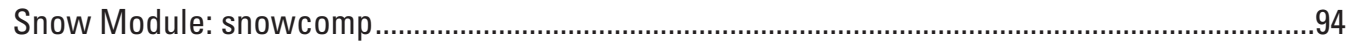

General Theory

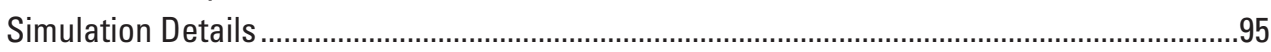

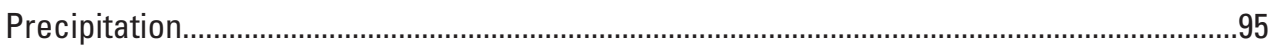




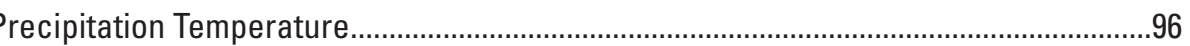

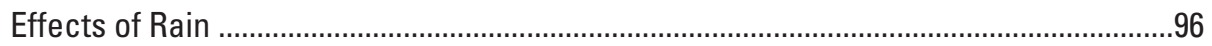

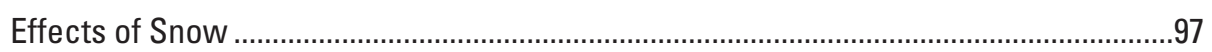

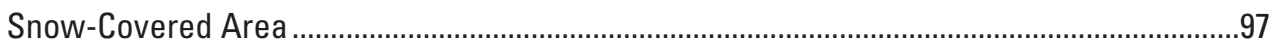

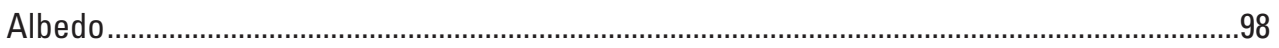

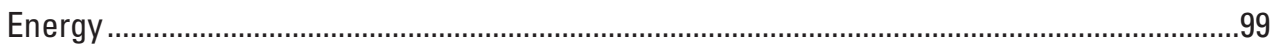

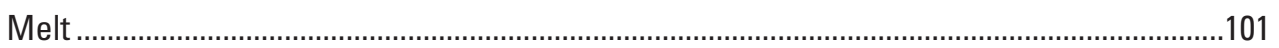

Sublimation ........................................................................................................................ 102

Surface-Runoff Modules: srunoff_smidx and srunoff_carea ..........................................................102

Impervious Storage and Evaporation ............................................................................... 102

Pervious Hortonian Surface Runoff and Infiltration.............................................................103

Surface-Depression Simulation ..........................................................................................104

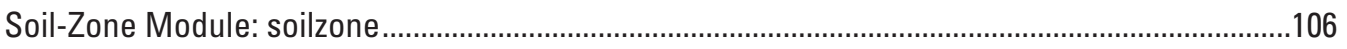

Description of Conceptual Reservoirs ............................................................................. 107

Computation Order............................................................................................................ 107

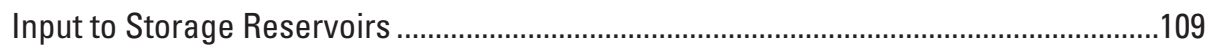

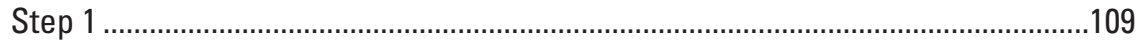

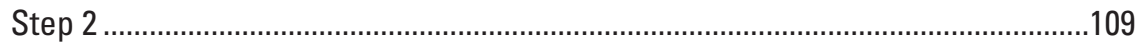

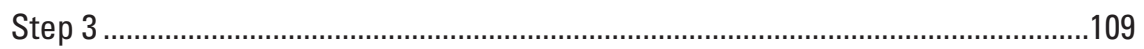

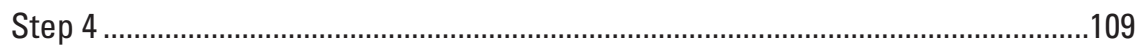

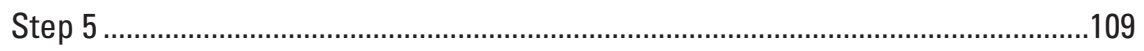

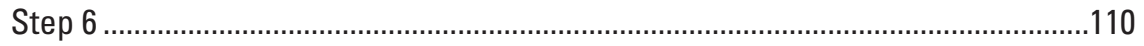

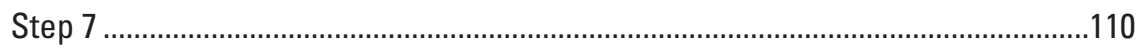

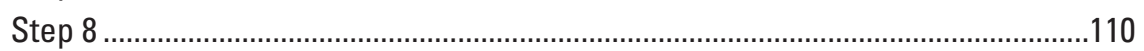

Outflows from Soil-Zone Storage Reservoirs ...............................................................111

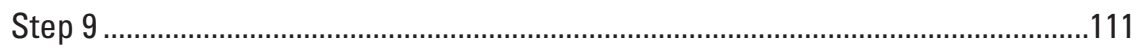

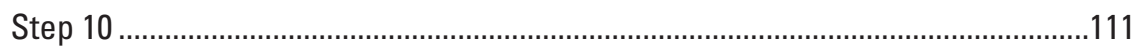

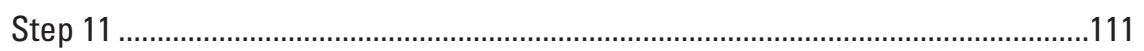

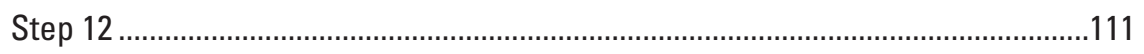

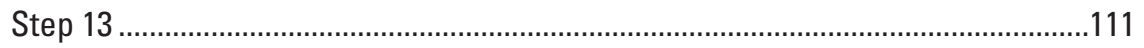

Evapotranspiration from the Capillary Reservoir ............................................................112

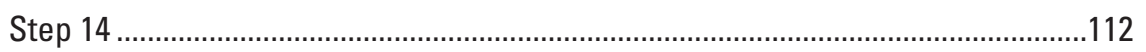

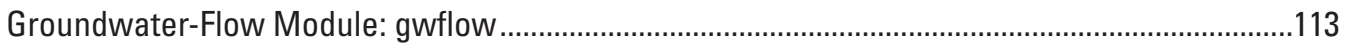

Streamflow Modules ...................................................................................................................113

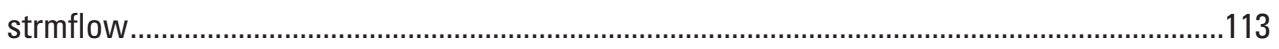

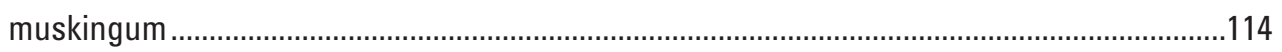

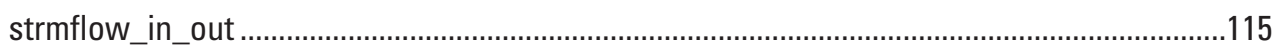

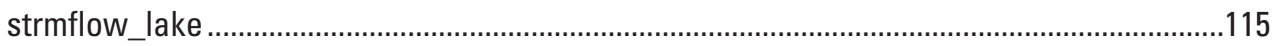

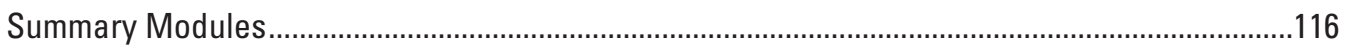

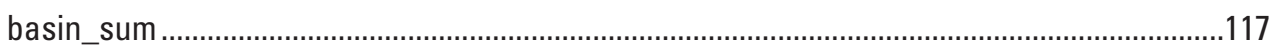

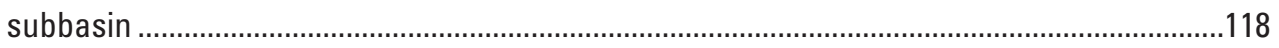

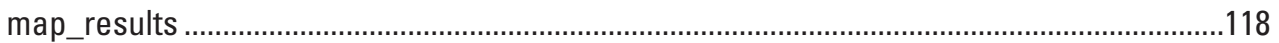

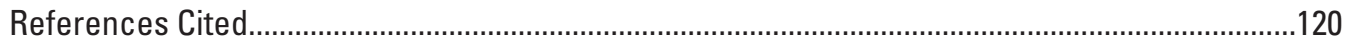




\section{Figures}

1-1. Example Hydrologic Response Unit (HRU) connectivity to a stream. HRUs are numbered 1 to 10 and stream segments 1 to 4

1-2. Diagram showing cascading flow of surface runoff and interflow among hydrologic response units and stream segments. Cascading flow delineated from $A$, topology, climate, and vegetation; and $B$, a finite-difference grid.. . .76

1-3. Example of coaxial relationship for estimating short-wave solar radiation from maximum daily air temperature developed for northwestern Colorado

1-4. Example of a snow-covered area depletion curve (solid line), as defined by 11 points (diamonds). The horizontal axis represents the fraction of the maximum snow-water equivalent (SWE) attained by the modeled snowpack. The vertical axis represents the fraction of maximum land area covered by snow. The dashed line is an example of a linearly interpolated depletion after a secondary snow accumulation. For a hypothetical snowpack, arrows indicate simulations for: $(A$ to $B$ ) initial accumulation, $(B$ to $C)$ melt, $(C$ to $D)$ secondary accumulation (that is, new snow), and ( $D$ to $E$ ) melt of that secondary accumulation.

1-5. Albedo decay curves relative to the number of days since the last new snow. Different curves apply for the snowpack accumulation and melt seasons. Both curves can be used during accumulation season, but only the lower curve will be used during melt season. During accumulation season, the top curve is used for the first 14 days since new snowfall. The dashed line represents the albedo value at which the curves overlap. During melt season, only the lower curve is used.

1-6. Example of the control parameters required to use the map_results module

\section{Tables}

1-1. Dimensions used in the Precipitation-Runoff Modeling System, version 4

1-2. Parameters specified in the Control File for the Precipitation-Runoff Modeling System, version 4

1-3. Parameters listed by usage with the associated modules in which they are used for the Precipitation-Runoff Modeling System, version 4.

1-4. Time-series input variables that may be included in the Data File for the Precipitation-Runoff Modeling System, version 4.

1-5. Input and output variables for the Precipitation-Runoff Modeling System, version 4

1-6. Sequence of steps used in the computation of flow into and out of the soil zone........108

1-7. Summary fields for Model Output Report File produced by the basin_sum module.....117

1-8. Typical sequence of output reports viewed during manual calibration exercise .........118 



\section{Appendix 1. PRMS-IV Module Documentation}

\section{Introduction}

This appendix describes the inputs and outputs, equations, computations, references, assumptions, and limitations of the modules included in the Precipitation-Runoff Modeling System, version 4 (PRMS-IV) hydrologic simulation model. Each module simulates part of the hydrologic cycle and is encoded as a FORTRAN 90 source code file, compiled and made available in the PRMS-IV executable. The PRMS-IV executable runs the user-specified modules in the correct sequence to simulate the full hydrologic cycle, including: (1) computation of climate distribution, (2) period of active transpiration, (3) potential evapotranspiration (PET), (4) canopy precipitation interception, (5) snowpack accumulation and depletion, (6) surface runoff and infiltration, (7) soil-zone moisture accounting, (8) groundwater flow, (9) streamflow routing, and (10) surface-depression storage. These modules, along with several others that are used for model setup, data input, and model output reports are described below.

Module documentation consists of a description, relevant equations, and tables describing the inputs and outputs. The symbols used in the equations are defined by the names in the tables. These names are consistent with the names used in the PRMS-IV input and output files and source code. These tables also define the dimension(s), units, type, valid value range, and default values.

\section{Styles and Formats}

The following font styles and formats are used in this appendix:

- Module variable names are identified in italic font.

- Module parameter and dimension names are identified in bold font.

- Module names are identified in Courier font.

\section{Data Types Used in the PRMS-IV Modules}

Dimensions are input values that set the array sizes of variables and parameters, such as the number of HRUs. The PRMS-IV dimensions (table 1-1) are specified at the beginning of the first Parameter File as specified in the Control File. 
Table 1-1. Dimensions used in the Precipitation-Runoff Modeling System, version 4 (PRMS-IV).

[HRU, hydrologic response unit; >, greater than; control parameters temp_module, precip_module, solrad_module, et_module, strmflow_module, subbasin_flag, cascade_flag, cascadegw_flag, and mapOutON_OFF defined in table 1-2; parameter hru_solsta defined in table 1-3]

\begin{tabular}{|c|c|c|c|}
\hline Dimension $^{3}$ & Description & Default & Required/Condition \\
\hline \multicolumn{4}{|c|}{ Spatial dimensions } \\
\hline ngw $^{2}$ & Number of groundwater reservoirs & 1 & required \\
\hline ngwcell & Number of spatial units in the target map for mapped results & 0 & mapOutON_OFF $=1$ \\
\hline nhru & Number of hydrologic response units & 1 & required \\
\hline nhrucell & $\begin{array}{l}\text { Number of unique intersections between HRUs and spatial units of a target map for } \\
\text { mapped results }\end{array}$ & 0 & mapOutON_OFF $=1$ \\
\hline nlake & Number of lake HRUs & 0 & strmflow_module $=$ strmflow_lake \\
\hline nradpl & Number of solar radiation planes - deprecated & 0 & solrad_module $=$ ccsolrad_prms or ddsolrad_prms \\
\hline nsegment & Number of stream-channel segments & 0 & $\begin{array}{l}\text { strmflow_module }=\text { strmflow_lake, muskingum, or strmflow_in_out or } \\
\text { cascade_flag }=1 \text { or cascadegw_flag }=1\end{array}$ \\
\hline $\mathbf{n s s r}^{2}$ & Number of subsurface reservoirs & 1 & required \\
\hline nsub & Number of internal subbasins & 0 & subbasin_flag $=1$ \\
\hline \multicolumn{4}{|c|}{ Time-series input data dimensions ${ }^{1}$} \\
\hline nevap & Number of pan-evaporation data sets & 0 & et_module $=$ potet_pan \\
\hline nhumid & Number of relative humidity measurement stations & 0 & optional \\
\hline nlakeelev & Maximum number of lake elevations for any rating table data set & 0 & strmflow_module $=$ strmflow_lake \\
\hline nobs & Number of streamflow-measurement stations & 0 & $\begin{array}{l}\text { replacement flow when strmflow_module }=\text { strmflow_lake, musk- } \\
\text { ingum, or strmflow_in_out }\end{array}$ \\
\hline nrain & Number of precipitation-measurement stations & 0 & $\begin{array}{l}\text { precip_module } \\
\text { xyz_dist }\end{array}$ \\
\hline nratetbl & Number of rating-table data sets for lake elevations & 0 & strmflow_module $=$ strmflow_lake \\
\hline nsnow & Number of snow-depth measurement stations & 0 & optional \\
\hline nsol & Number of solar-radiation measurement stations & 0 & computation of solar radiation distribution using parameter hru_solsta \\
\hline ntemp & Number of air-temperature-measurement stations & 0 & $\begin{array}{l}\text { temp_module }=\text { temp_1sta, temp_2sta_prms-deprecated, temp_laps, } \\
\text { temp_dist } 2, \text { ide_dist, or xyz_dist }\end{array}$ \\
\hline nwind & Number of wind-speed measurement stations & 0 & optional \\
\hline \multicolumn{4}{|c|}{ Computation dimensions } \\
\hline ncascade & Number of HRU links for cascading flow & 0 & cascade_flag $=1$ \\
\hline ncascdgw & Number of GWR links for cascading flow & 0 & cascadegw_flag $=1$ \\
\hline ndepl & Number of snow-depletion curves & 1 & required \\
\hline ndeplval & Number of values in all snow-depletion curves (set to ndepl*11) & 11 & required \\
\hline
\end{tabular}


Table 1-1. Dimensions used in the Precipitation-Runoff Modeling System, version 4 (PRMS-IV).-Continued

[HRU, hydrologic response unit; >, greater than; control parameters temp_module, precip_module, solrad_module, et_module, strmflow_module, subbasin_flag, cascade_flag, cascadegw_flag, and mapOutON_OFF defined in table 1-2; parameter hru_solsta defined in table 1-3]

\begin{tabular}{|c|c|c|c|}
\hline Dimension $^{3}$ & Description & Default & Required/Condition \\
\hline \multicolumn{4}{|c|}{ Lake computation dimensions } \\
\hline mxnsos & $\begin{array}{l}\text { Maximum number of storage/outflow table values for storage-detention reservoirs } \\
\text { and lakes connected to the stream network using Puls routing }\end{array}$ & 0 & strmflow_module $=$ strmflow_lake \\
\hline ngate & Maximum number of reservoir gate-opening values (columns) for lake rating table 1 & 0 & strmflow_module $=$ strmflow_lake and nratetbl $>0$ \\
\hline ngate2 & Maximum number of reservoir gate-opening values (columns) for lake rating table 2 & 0 & strmflow_module $=$ strmflow_lake and nratetbl $>1$ \\
\hline ngate3 & Maximum number of reservoir gate-opening values (columns) for lake rating table 3 & 0 & strmflow_module $=$ strmflow_lake and nratetbl $>2$ \\
\hline ngate4 & Maximum number of reservoir gate-opening values (columns) for lake rating table 4 & 0 & strmflow_module $=$ strmflow_lake and nratetbl $>3$ \\
\hline nstage & Maximum number of lake elevations values (rows) for lake rating table 1 & 0 & strmflow_module $=$ strmflow_lake and nratetbl $>0$ \\
\hline nstage 2 & Maximum number of lake elevations values (rows) for lake rating table 2 & 0 & strmflow_module $=$ strmflow_lake and nratetbl $>1$ \\
\hline nstage3 & Maximum number of lake elevations values (rows) for lake rating table 3 & 0 & strmflow_module $=$ strmflow_lake and nratetbl $>2$ \\
\hline nstage4 & Maximum number of lake elevations values (rows) for lake rating table 4 & 0 & strmflow_module $=$ strmflow_lake and nratetbl $>3$ \\
\hline \multicolumn{4}{|c|}{ Fixed dimensions } \\
\hline ndays & Maximum number of days in a year & 366 & optional \\
\hline nlapse & Number of lapse rates in $\mathrm{X}, \mathrm{Y}$, and $\mathrm{Z}$ directions & 3 & precip_module $=x y z \_d i s t$ \\
\hline nmonths & Number of months in a year & 12 & optional \\
\hline one & Dimension of scalar parameters and variables & 1 & optional \\
\hline
\end{tabular}

${ }^{1}$ All associated data specified in Data File can be used for calibration purposes.

${ }^{2}$ Use of nssr and ngw not equal to nhru is deprecated.

${ }^{3}$ Dimensions that do not have an associated parameter specified in the Parameter File or variable specified in the Data File are optional. 
Parameters are user-specified input values that do not change during a simulation, such as the name of the Parameter and Data Files, simulation start time, and the area and type of each hydrologic response unit (HRU). All parameters are defined as arrays. Scalar parameters, such as watershed area, have an array size of 1 and are specified by using the dimension one. PRMS-IV parameters that can be specified in the Control File (see Appendix 2 for a description of the Control File format) are described in table 1-2. Parameters that can be specified in the Parameter File and the modules that use them are listed in table 1-3. Additional information regarding selected control parameters is presented below to augment table 1-2:

- start_time and end_time - are used to specify the starting and ending times of the simulation. Both times are specified by using six lines of integer values in the following order: year, month, day, hour, minute, and second. The specified times must include time-series data items of the specified time period in the Data File (see Appendix 2 for a description of the Data File format). PRMS-IV only allows a daily time step; values for hour, minute, and second should be set to 0 .

- et_module, precip_module, soilzone_module, solrad_module, srunoff_module, strmflow_module, temp_module, and transp_module - are used to select a PRMS-IV module for the corresponding process. The computations for each process are described in this appendix. If the module xyz_dist or ide_dist is selected for the temperature-distribution method (temp_module), this module also must be selected as the precipitation-distribution module (precip_module), and vice versa.

- data_file - is used to specify a list of Data Files to use in a simulation. Typically, a single Data File is used. If more than one is specified, all of them are used.

- param_file - is used to specify a list of Parameters Files to use in a simulation. Typically, a single Parameter File is used. If more than one is specified, all of them are used in the order specified.

- statVar_names and aniOutVar_names - are used to specify lists of names of output variables (states and fluxes) to include in the Statistic Variables (statvar) File and Animation File(s), respectively. A description of these files is given in the section "Output Files" in Appendix 2. All output variables listed in the tables of this appendix are available for inclusion in the Statistic Variables and Animation Variables files for analysis and debugging purposes. Users can select as many output variables as desired to include in both files by using control parameters nstatVars and naniOutVars, respectively. If control parameter statsON_OFF is set to 0, the Statistic Variables File is not created and values of statVar_names and nstatVars are ignored. Likewise, if control parameter aniOutON_OFF is set to 0, Animation File(s) are not created and values of aniOutVar_names and naniOutVars are ignored.

- ani_output_file _ - is used as the root filename for Animation File(s). A separate output file is generated for each dimension associated with the list of variables, specified by aniOutVar_names when aniOutON_OFF is set to 1. Variables with the same dimension are included in a single file. The names of each file differ in the suffix appended to ani_output_file. The suffix for each file is set to the dimension name. For example, if ani_output_file is specified as./output/ sagehen_ani and variables with dimension nhru are specified in the aniOutVar_names list of variable names, the file .loutput/sagehen_ani.nhru is generated.

init_vars_from_file, var_init_file, save_vars_to_file, var_save_file_-are used to specify whether or not the state of the model, that is, values of input parameters and computed results (states and fluxes) will be read from and(or) written to Initial Conditions (IC) Files. The values written to an IC File represents the conditions for the last day of a simulation time period and a particular set of computation options. This file can be input as the initial (or antecedent) conditions of subsequent (or restart) simulations using the identical computation options. The IC Files are typically the result of a long, time-period "spinup" simulation computed to account for the hydrologic memory throughout the model domain and historical climate conditions. An IC File should only be used as input to a restart simulation as a continuation from the last day of the spin-up simulation. To read a valid IC File specify init_vars_from_file equal 1 and the pathname using var_init_file. To generate an IC File specify save_vars_to_file equal 1 and the pathname using var_save_file. If the values of var_init_file and var_save_file are equal and init_vars_from_file and save_vars_to_file equal 1, then the original IC File input to the simulation is overwritten with the state of the model at the end of the simulation. One use of the IC File option is for forecasting hydrologic conditions. For example, a series of predicitive simulations can be generated based on ensembles of projected climate forecasts (that is, particular realizations of future conditions) and identical initial conditions, previously computed for a selected date. Another possible use is in model calibration procedures that require identical initial conditions for each of the required calibration simulations. 
Table 1-2. Parameters specified in the Control File for the Precipitation-Runoff Modeling System, version 4 (PRMS-IV).

[Data Type: $1=$ integer, $2=$ single precision floating point (real), $3=$ double precision floating point (double); $4=$ character string; HRU, hydrologic response unit; GWR, groundwater reservoir; CBH, climate-byHRU; ET, evapotranspiration; >, greater than; dimensions ncascade, ncascdgw, and nsub defined in table 1-1; modules soltab_prms, temp_2sta_prms, ccsolrad_prms, ddsolrad_prms, potet_hamon_prms, smbal_prms, ssflow_prms, and hru_sum_prms are deprecated and only included for backwards compatibility for PRMS models built prior to PRMS-IV; the first two blocks of control parameters listed in the table are recommended for every simulation, though all parameters are optional depending appropriateness of the default values]

\begin{tabular}{|c|c|c|c|c|c|}
\hline $\begin{array}{l}\text { Parameter } \\
\text { name }\end{array}$ & Description & Option & $\begin{array}{l}\text { Number of } \\
\text { values }\end{array}$ & $\begin{array}{l}\text { Data } \\
\text { type }\end{array}$ & $\begin{array}{l}\text { Default } \\
\text { value }\end{array}$ \\
\hline \multicolumn{6}{|c|}{ Simulation execution and required input and output files } \\
\hline data_file ${ }^{2}$ & $\begin{array}{l}\text { Pathname(s) for measured input Data File(s), typically a single Data File is } \\
\text { specified }\end{array}$ & measured input & number of Data Files & 4 & prms.data \\
\hline end_time & $\begin{array}{l}\text { Simulation end date and time specified in order in the control item as: year, } \\
\text { month, day, hour, minute, second }\end{array}$ & time period & 6 & 1 & $2001,9,30,0,0,0$ \\
\hline model_mode & $\begin{array}{l}\text { Flag to indicate the simulation mode (PRMS=PRMS; FROST=growing } \\
\text { season for each HRU; WRITE_CLIMATE=write CBH files of } \\
\text { minimum and maximum air temperature (variables } \text { tminf } \text { and } \text { tmaxf- } \\
\text { Fahrenheit); precipitation (variable } h r u \_p p t \text {-inches); solar radiation } \\
\text { (variable } \text { swrad-Langleys); potential ET (variable } \text { potet-inches); and/ } \\
\text { or transpiration flag (variable } \text { transp_on-none); POTET=simulate } \\
\text { to potential ET; TRANSPIRE=simulate to transpiration period; } \\
\text { DOCUMENTATION=write files of all declared parameters and variables } \\
\text { in the executable) }\end{array}$ & $\begin{array}{l}\text { simulation mode } \\
\text { selection }\end{array}$ & 1 & 4 & PRMS \\
\hline model_output_file ${ }^{2}$ & $\begin{array}{l}\text { Pathname for Water-Budget File for results module basin_sum and hru_sum } \\
\text { prms_-deprecated }\end{array}$ & simulation output & 1 & 4 & prms.out \\
\hline param_file ${ }^{2}$ & Pathname(s) for Parameter File(s) & parameter input & $\begin{array}{l}\text { number of Parameter } \\
\text { Files }\end{array}$ & 4 & prms.params \\
\hline start_time & $\begin{array}{l}\text { Simulation start date and time specified in order in the control item as: year, } \\
\text { month, day, hour, minute, second }\end{array}$ & time period & 6 & 1 & $2000,10,1,0,0,0$ \\
\hline
\end{tabular}

Module selection and simulation options

cascade_flag

Flag to indicate if HRU cascades are computed ( $0=$ no; $1=$ yes $)$

cascadegw_flag

Flag to indicate if GWR cascades are computed $(0=$ no; $1=$ yes $)$

dprst_flag

Flag to indicate if depression-storage simulation is computed $(0=$ no; $1=$ yes)

et_module

Module name for potential evapotranspiration method (climate_hru, potet jh, potet_hamon, potet_hs, potet_pt, potet_pm, potet_pan, or potet_hamon_prms-deprecated)

precip_module

Module name for precipitation-distribution method (climate hru, ide_dist, precip_1sta, precip_dist2, precip_laps, or xyz_dist)

soilzone_module

Module name for capillary and gravity reservoir simulation method; either soilzone or deprecated modules smbal_prms and ssflow_prms (soilzone or

cascade flow with

ncascade $>0$

cascade flow with

ncascdgw $>0$

surface-depression storage

module selection

module selection

module selection
1

1

1

1

1
1

1

0

potet_jh

precip_1sta

soilzone smbal_prms) 
[Data Type: 1=integer, 2=single precision floating point (real), 3=double precision floating point (double); 4=character string; HRU, hydrologic response unit; GWR, groundwater reservoir; CBH, climate-byHRU; ET, evapotranspiration; >, greater than; dimensions ncascade, ncascdgw, and nsub defined in table 1-1; modules soltab_prms, temp_2sta_prms, ccsolrad_prms, ddsolrad_prms, potet_hamon_prms, smbal prms, ssflow prms, and hru sum prms are deprecated and only included for backwards compatibility for PRMS models built prior to PRMS-IV; the first two blocks of control parameters listed in the table are recommended for every simulation, though all parameters are optional depending appropriateness of the default values]

\begin{tabular}{|c|c|c|c|c|c|}
\hline $\begin{array}{l}\text { Parameter } \\
\text { name }\end{array}$ & Description & Option & $\begin{array}{l}\text { Number of } \\
\text { values }\end{array}$ & $\begin{array}{l}\text { Data } \\
\text { type }\end{array}$ & $\begin{array}{l}\text { Default } \\
\text { value }\end{array}$ \\
\hline solrad_module & $\begin{array}{l}\text { Module name for solar-radiation-distribution method (ccsolrad, ddsolrad, } \\
\text { ccsolrad_prms_-deprecated, or ddsolrad_prms_-deprecated; if either } \\
\text { deprecated module is specified, soltab_prms_-deprecated is used instead } \\
\text { of the soltab module and hru_sum_prms is active) }\end{array}$ & module selection & 1 & 4 & ddsolrad \\
\hline srunoff_module & $\begin{array}{l}\text { Module name for surface-runoff/infiltration computation method (srunoff_ } \\
\text { carea or srunoff_smidx) }\end{array}$ & module selection & 1 & 4 & srunoff_smidx \\
\hline strmflow_module & $\begin{array}{l}\text { Module name for streamflow routing simulation method (strmflow, musk- } \\
\text { ingum, strmflow_in_out, or strmflow_lake) }\end{array}$ & module selection & 1 & 4 & strmflow \\
\hline subbasin_flag & Flag to indicate if internal subbasin are computed $(0=$ no; $1=$ yes $)$ & nsub $>0$ & 1 & 1 & 1 \\
\hline temp_module & $\begin{array}{l}\text { Module name for temperature-distribution method (climate_hru, temp_1sta, } \\
\text { temp_dist2, temp_laps, ide_dist, xyz_dist, or temp_2sta_prms- } \\
\text { deprecated) }\end{array}$ & module selection & 1 & 4 & temp_1sta \\
\hline transp_module & $\begin{array}{l}\text { Module name for transpiration simulation method (climate_hru, transp_frost, } \\
\text { or transp_tindex) }\end{array}$ & module selection & 1 & 4 & transp_tindex \\
\hline \multicolumn{6}{|c|}{ Climate-by-HRU Files } \\
\hline humidity_day ${ }^{2}$ & $\begin{array}{l}\text { Pathname of the CBH file of pre-processed humidity input data for each } \\
\text { HRU to specify variable humidity_hru-decimal fraction }\end{array}$ & et_module $=$ potet_pm & 1 & 4 & humidity.day \\
\hline orad_flag & $\begin{array}{l}\text { Flag to specify whether or not the variable orad is specified as the last col- } \\
\text { umn of the swrad_day CBH file }(0=\text { no; } 1=\text { yes })\end{array}$ & $\begin{array}{l}\text { solrad_module }= \\
\text { climate_hru }\end{array}$ & 1 & 1 & 1 \\
\hline potet_day $^{2}$ & $\begin{array}{l}\text { Pathname of the CBH file of pre-processed potential-ET input data for each } \\
\text { HRU to specify variable potet-inches }\end{array}$ & $\begin{array}{l}\text { et_module }= \\
\text { climate_hru }\end{array}$ & 1 & 4 & potet.day \\
\hline precip_day $^{2}$ & $\begin{array}{l}\text { Pathname of the } \mathrm{CBH} \text { file of pre-processed precipitation input data for each } \\
\text { HRU to specify variable precip-inches }\end{array}$ & $\begin{array}{l}\text { precip_module } \\
\quad \text { climate_hru }\end{array}$ & 1 & 4 & precip.day \\
\hline swrad_day ${ }^{2}$ & $\begin{array}{l}\text { Pathname of the CBH file of pre-processed solar-radiation input data for } \\
\text { each HRU to specify variable swrad-Langleys }\end{array}$ & $\begin{array}{l}\text { solrad_module }= \\
\text { climate_hru }\end{array}$ & 1 & 4 & swrad.day \\
\hline tmax_day ${ }^{2}$ & $\begin{array}{l}\text { Pathname of the } \mathrm{CBH} \text { file of pre-processed maximum air temperature input } \\
\text { data for each HRU to specify variable tmaxf-degrees Fahrenheit }\end{array}$ & $\begin{array}{l}\text { temp_module }= \\
\text { climate_hru }\end{array}$ & 1 & 4 & tmax.day \\
\hline tmin_day ${ }^{2}$ & $\begin{array}{l}\text { Pathname of the } \mathrm{CBH} \text { file of pre-processed minimum air temperature input } \\
\text { data for each HRU to specify variable tminf-degrees Fahrenheit }\end{array}$ & $\begin{array}{l}\text { temp_module }= \\
\text { climate_hru }\end{array}$ & 1 & 4 & tmin.day \\
\hline transp_day ${ }^{2}$ & $\begin{array}{l}\text { Pathname of the } \mathrm{CBH} \text { file of pre-processed transpiration on or off flag for } \\
\text { each HRU file to specify variable transp_on-none }\end{array}$ & $\begin{array}{l}\text { transp_module }= \\
\text { climate_hru }\end{array}$ & 1 & 4 & transp.day \\
\hline windspeed_day ${ }^{2}$ & $\begin{array}{l}\text { Pathname of the CBH file of pre-processed wind speed input data for each } \\
\text { HRU to specify variable windspeed_hru-meters/second }\end{array}$ & et_module $=$ potet_pm & 1 & 4 & windspeed.day \\
\hline
\end{tabular}


Table 1-2. Parameters specified in the Control File for the Precipitation-Runoff Modeling System, version 4 (PRMS-IV).—Continued

[Data Type: 1=integer, $2=$ single precision floating point (real), $3=$ double precision floating point (double); $4=$ character string; HRU, hydrologic response unit; GWR, groundwater reservoir; CBH, climate-byHRU; ET, evapotranspiration; >, greater than; dimensions ncascade, ncascdgw, and nsub defined in table 1-1; modules soltab_prms, temp_2sta_prms, ccsolrad_prms, ddsolrad_prms, potet_hamon_prms, smbal_prms, ssflow_prms, and hru_sum_prms are deprecated and only included for backwards compatibility for PRMS models built prior to PRMS-IV; the first two blocks of control parameters listed in the table are recommended for every simulation, though all parameters are optional depending appropriateness of the default values]

\begin{tabular}{|c|c|c|c|c|c|}
\hline $\begin{array}{l}\text { Parameter } \\
\text { name }\end{array}$ & Description & Option & $\begin{array}{l}\text { Number of } \\
\text { values }\end{array}$ & $\begin{array}{l}\text { Data } \\
\text { type }\end{array}$ & $\begin{array}{l}\text { Default } \\
\text { value }\end{array}$ \\
\hline \multicolumn{6}{|c|}{ Debug options } \\
\hline cbh_check_flag & Flag to indicate if $\mathrm{CBH}$ values are validated each time step $(0=$ no; $1=\mathrm{yes})$ & CBH input & 1 & 1 & 1 \\
\hline parameter_check_flag & $\begin{array}{l}\text { Flag to indicate if selected parameter values validation checks are treated as } \\
\text { warnings or errors }(0=\text { no; } 1=\text { yes; } 2=\text { check parameters and then stop) }\end{array}$ & parameter input & 1 & 1 & 1 \\
\hline print_debug ${ }^{1}$ & $\begin{array}{l}\text { Flag to indicate type of debug output } \\
(-1=\text { minimize screen output; } 0=\text { none; } 1=\text { water balances; } 2=\text { basin module; } \\
\text { 4=basin_sum module; } 5=\text { soltab module; } 7=\text { soilzone module; } 9=\text { snowcomp } \\
\text { module; } 13=\text { cascade module; } 14=\text { subbasin module })\end{array}$ & debug output & 1 & 1 & 0 \\
\hline \multicolumn{6}{|c|}{ Statistic Variables (statvar) Files } \\
\hline nstatVars & $\begin{array}{l}\text { Number of variables to include in Statistics Variables File and names speci- } \\
\text { fied in statVar_names }\end{array}$ & statsON_OFF $=1$ & 1 & 1 & 0 \\
\hline stat_var_file ${ }^{2}$ & Pathname for Statistics Variables File & statsON_OFF $=1$ & 1 & 4 & statvar.out \\
\hline statsON_OFF & $\begin{array}{l}\text { Switch to specify whether or not the Statistics Variables File is generated } \\
(0=\text { no; } 1=\text { statvar text format; } 2=\mathrm{CSV} \text { format })\end{array}$ & statsON_OFF $=1$ & 1 & 1 & 0 \\
\hline statVar_element & $\begin{array}{l}\text { List of identification numbers corresponding to variables specified in stat- } \\
\text { Var_names list (1 to variable's dimension size) }\end{array}$ & statsON_OFF $=1$ & nstatVars & 4 & none \\
\hline statVar_names ${ }^{3}$ & List of variable names for which output is written to Statistics Variables File & statsON_OFF $=1$ & nstatVars & 4 & none \\
\hline \multicolumn{6}{|c|}{ Initial Condition Files } \\
\hline init_vars_from_file & $\begin{array}{l}\text { Flag to specify whether or not the Initial Conditions File is specified as an } \\
\text { input file }(0=\text { no; } 1=\text { yes; } 2=\text { yes and use parameter values in Parameter File } \\
\text { instead of values in Initial Conditions File) }\end{array}$ & initial condtions & 1 & 1 & 0 \\
\hline save_vars_to_file & $\begin{array}{l}\text { Flag to determine if an Initial Conditions File will be generated at the end of } \\
\text { simulation ( } 0=\text { no; } 1=\text { yes })\end{array}$ & initial condtions & 1 & 1 & 0 \\
\hline var_init_file ${ }^{2}$ & Pathname for Initial Conditions input file & init_vars_from_file $=1$ & 1 & 4 & prms_ic.in \\
\hline var_save_file ${ }^{2}$ & Pathname for the Initial Conditions File to be generated at end of simulation & save_vars_to_file $=1$ & 1 & 4 & prms_ic.out \\
\hline \multicolumn{6}{|c|}{ Animation Files } \\
\hline ani_output_file ${ }^{2}$ & $\begin{array}{l}\text { Root pathname for Animation Files(s) to which a filename suffix based on } \\
\text { dimension name associated with selected variables is appended }\end{array}$ & aniOutON_OFF $=1$ & 1 & 4 & animation.out \\
\hline aniOutON_OFF & $\begin{array}{l}\text { Switch to specify whether or not Animation File(s) are generated }(0=\text { no; } \\
1=\text { yes })\end{array}$ & animation output & 1 & 1 & 0 \\
\hline
\end{tabular}


[Data Type: 1=integer, 2=single precision floating point (real), 3=double precision floating point (double); 4=character string; HRU, hydrologic response unit; GWR, groundwater reservoir; CBH, climate-byHRU; ET, evapotranspiration; >, greater than; dimensions ncascade, ncascdgw, and nsub defined in table 1-1; modules soltab_prms, temp_2sta_prms, ccsolrad_prms, ddsolrad_prms, potet_hamon_prms, smbal prms, ssflow prms, and hru sum prms are deprecated and only included for backwards compatibility for PRMS models built prior to PRMS-IV; the first two blocks of control parameters listed in the table are recommended for every simulation, though all parameters are optional depending appropriateness of the default values]

\begin{tabular}{|c|c|c|c|c|c|}
\hline $\begin{array}{l}\text { Parameter } \\
\text { name }\end{array}$ & Description & Option & $\begin{array}{l}\text { Number of } \\
\text { values }\end{array}$ & $\begin{array}{l}\text { Data } \\
\text { type }\end{array}$ & $\begin{array}{l}\text { Default } \\
\text { value }\end{array}$ \\
\hline aniOutVar_names $^{3}$ & $\begin{array}{l}\text { List of variable names for which all values of the variable (that is, the entire } \\
\text { dimension size) for each time step are written Animation Dimension } \\
\text { Files(s) }\end{array}$ & aniOutON_OFF = 1 & naniOutVars & 4 & none \\
\hline naniOutVars & Number of output variables specified in the aniOutVar_names list & aniOutON_OFF $=1$ & 1 & 1 & 0 \\
\hline \multicolumn{6}{|c|}{ Mapped Results Files } \\
\hline mapOutON_OFF & $\begin{array}{l}\text { Switch to specify whether or not mapped output file(s) by a specified number } \\
\text { of columns (parameter ncol) of monthly, yearly, or total simulation results } \\
\text { is generated ( } 0=\text { no; } 1=\text { yes) }\end{array}$ & mapped results & 1 & 1 & 0 \\
\hline mapOutVar_names ${ }^{3}$ & List of variable names for which output is written to mapped output files(s) & $\underset{=1}{\text { map_resultsON_OFF }}$ & nmapVars & 4 & none \\
\hline nmapOutVars & Number of variables to include in mapped output file(s) & $\begin{array}{c}\text { map_resultsON_OFF } \\
=1\end{array}$ & 1 & 1 & 0 \\
\hline \multicolumn{6}{|c|}{ Runtime graphs } \\
\hline dispGraphsBuffSize & Number of time steps to wait before updating the runtime graph & ndispGraphs $>0$ & 1 & 1 & 50 \\
\hline dispVar_element & $\begin{array}{l}\text { List of identification numbers corresponding to variables specified in } \\
\text { dispVar_names list ( } 1 \text { to variable's dimension size) }\end{array}$ & ndispGraphs $>0$ & number of variables & 4 & none \\
\hline dispVar_names ${ }^{3}$ & List of variable names for which plots are output to the runtime graph & ndispGraphs $>0$ & number of variables & 4 & none \\
\hline dispVar_plot & List of variable names for which plots are output to the runtime graph & ndispGraphs $>0$ & number of variables & 4 & none \\
\hline executable_desc & Descriptive text to identify the PRMS-IV executable & ndispGraphs $>0$ & 1 & 4 & MOWS executable \\
\hline executable_model $^{2}$ & Pathname (full or relative) of the PRMS-IV executable & ndispGraphs $>0$ & 1 & 4 & prmsIV \\
\hline initial_deltat & Initial time step for the simulation & ndispGraphs $>0$ & 1 & 2 & 24.0 \\
\hline ndispGraphs & Number of plots included in the runtime graph & graphical output & 1 & 1 & 0 \\
\hline
\end{tabular}

${ }^{1}$ File and screen output options: $1=$ water balance output files written in current directory, for intcp module file intcp.wbal; for snowcomp module snowcomp.wbal; for srunoff module srunoff_smidx. wbal or srunoff_carea.wbal; for soilzone module soilzone.wbal; for gwflow module gwflow.wbal; $2=$ bas in module output written to screen; $4=b a s$ in sum debug information written to file basin_sum. $\mathrm{dbg}$ in current directory; $5=\mathrm{sol}$ tab module output written to the file soltab debug in current directory; $7=$ soil zone debug information concerning input parameter consistency written to file soilzone.dbg in current directory; $9=$ arrays of net_rain, net_snow, and snowmelt written to screen; $13=$ subbas in error and warning messages and cascade paths are written to the file cascade.msgs in current directory; $14=$ subbas in computation order written to file tree_structure in current directory.

${ }^{2}$ Pathnames for all files can have a maximum of 132 characters.

${ }^{3}$ Variable names can have a maximum of 32 characters. 
Table 1-3. Parameters listed by usage with the associated modules in which they are used for the Precipitation-Runoff Modeling System, version 4 (PRMS-IV).

[HRU, hydrologic response unit; GWR, groundwater reservoir; cfs, cubic feet per second; cms, cubic meters per second; ET, evapotranspiration; dday, degree-day, the amount a day's average temperature departed from 65 degrees Fahrenheit; >, greater than; dimensions defined in table 1-1; control parameters temp_module, precip_module, solrad_module, et_module, transp_module, srunoff_module, strmflow_module, soilzone_module, model_mode, dprst_flag, subbasin_flag, cascade_flag, cascadegw_flag, and mapOutON_OFF defined in table 1-2. Note: modules soltab_prms, temp_2sta_prms, ccsolrad_prms, ddsolrad_prms, potet_hamon_prms, smbal_prms, ssflow_prms, and hru_sum_prms are deprecated and only included for backwards compatibility for PRMS models built prior to PRMS-IV]

\begin{tabular}{|c|c|c|c|c|c|c|c|}
\hline $\begin{array}{l}\text { Parameter } \\
\text { name }\end{array}$ & Description & Dimension' ${ }^{1}$ & Type & Units & Range & Default & Required/condition \\
\hline \multicolumn{8}{|c|}{ Basic physical attributes } \\
\hline basin_area & Area of basin & one & real & acres & 0.0 to $1.0 \mathrm{E} 9$ & 1.0 & deprecated $^{10}$ \\
\hline elev_units & $\begin{array}{l}\text { Flag to indicate the units of elevation values } \\
\qquad(0=\text { feet; } 1=\text { meters })\end{array}$ & one & integer & none & 0 or 1 & 0 & required \\
\hline hru_area & Area of each HRU & nhru & real & acres & 0.01 to $1.0 \mathrm{E} 9$ & 1.0 & required \\
\hline hru_aspect & Aspect of each HRU & nhru & real & angular degrees & 0.0 to 360.0 & 0.0 & required $^{6}$ \\
\hline hru_elev & Mean elevation for each HRU & nhru & real & elev_units & $\begin{array}{c}-1,000.0 \text { to } \\
30,000.0\end{array}$ & 0.0 & required \\
\hline hru_lat & Latitude of each HRU & nhru & real & angular degrees & -90.0 to 90.0 & 40.0 & required $^{6}$ \\
\hline hru_radpl & $\begin{array}{l}\text { Index of radiation plane used to compute solar } \\
\text { radiation for each HRU }\end{array}$ & nradpl & integer & none & 1 to $\mathbf{n r a d p l}$ & 1 & $\begin{array}{l}\text { solrad_module = } \\
\text { ddsolrad_prms or } \\
\text { ccsolrad_prms }\end{array}$ \\
\hline hru_slope & Slope of each HRU & nhru & real & decimal fraction & 0.0 to 10.0 & 0.0 & required $^{6}$ \\
\hline hru_type ${ }^{5}$ & $\begin{array}{l}\text { Type of each HRU ( } 0=\text { inactive; } 1=\text { land; } 2=\text { lake; } \\
3=\text { swale) }\end{array}$ & nhru & integer & none & 0 to 3 & 1 & required \\
\hline \multicolumn{8}{|c|}{ Measured input } \\
\hline outlet_sta & $\begin{array}{l}\text { Index of measured streamflow station correspond- } \\
\text { ing to the basin outlet }\end{array}$ & one & integer & none & 1 to nobs & 0 & nobs $>0$ \\
\hline precip_units & $\begin{array}{l}\text { Flag to indicate the units of measured precipita- } \\
\text { tion values }(0=\text { inches; } 1=\mathrm{mm})\end{array}$ & one & integer & none & 0 or 1 & 0 & required \\
\hline rad_conv & $\begin{array}{l}\text { Conversion factor to Langleys for measured solar } \\
\text { radiation }\end{array}$ & one & real & $\begin{array}{l}\text { Langleys/ } \\
\text { radiation units }\end{array}$ & 0.1 to 100.0 & 1.0 & nsol $>0$ \\
\hline rain_code & $\begin{array}{l}\text { Monthly (January to December) flag indicating } \\
\text { rule for precipitation measurement station use } \\
\text { ( } 1=\text { only precipitation if the regression stations } \\
\text { have precipitation; } 2=\text { only precipitation if any } \\
\text { station in the basin has precipitation; } 3=\text { pre- } \\
\text { cipitation if module xyz_dist computes any; } \\
4=\text { only precipitation if rain_day variable is set } \\
\text { to } 1 ; 5=\text { only precipitation if psta_freq_nuse } \\
\text { stations have precipitation) }\end{array}$ & nmonths & integer & none & 1 to 5 & 2 & $\begin{array}{l}\text { precip_module } \\
\text { xyz_dist }\end{array}$ \\
\hline runoff_units & Measured streamflow units $(0=\mathrm{cfs} ; 1=\mathrm{cms})$ & one & integer & none & 0 or 1 & 0 & nobs $>0$ \\
\hline temp_units & $\begin{array}{l}\text { Flag to indicate the units of measured air-temper- } \\
\text { ature values }(0=\text { Fahrenheit; } 1=\text { Celsius })\end{array}$ & one & integer & none & 0 or 1 & 0 & required \\
\hline
\end{tabular}


[HRU, hydrologic response unit; GWR, groundwater reservoir; cfs, cubic feet per second; cms, cubic meters per second; ET, evapotranspiration; dday, degree-day, the amount a day's average temperature departed from 65 degrees Fahrenheit; >, greater than; dimensions defined in table 1-1; control parameters temp_module, precip_module, solrad_module, et_module, transp_module, srunoff_module, strmflow module, soilzone module, model_mode, dprst flag, subbasin flag, cascade flag, cascadegw flag, and mapOutON_OFF defined in table 1-2. Note: modules soltab prms, temp 2sta prms, ccsolrad_prms, ddsolrad_prms, potet_hamon_prms, smbal_prms, ssflow_prms, and hru_sum_prms are deprecated and only included for backwards compatibility for PRMS models built prior to PRMS-IV]

\begin{tabular}{cccccc}
$\begin{array}{c}\text { Parameter } \\
\text { name }\end{array}$ & Description & Dimension & Type & Units & Refault \\
\hline
\end{tabular}

dist_max

Maximum distance from an HRU to a measurement station for use in calculations

hi_index

hru_plaps

hru_psta

hru_tlaps

hru_tsta rate computations

Index of the lapse precipitation measurement HRU

Index of the base precipitation measurement HRU

Index of the lapse temperature station used for lapse rate calculations

Index of the base temperature station used for
Elevation conversion flag $(0=$ none; $1=$ feet to meters; $2=$ meters to feet)

Exponent for inverse distance calculations

one

real

feet

0.0 to $1.0 \mathrm{E} 9$

one

integer

none

1 to ntemp station used for lapse rate calculations for each station used for lapse rate calculations for each lapse rate calculations nhru

integer

none

1 to nrain

nhru

integer

none

nhru

integer

none

integer climate_hru

required

temp_module

$=$ temp 1sta,

temp_2sta_prms, temp_dist2, or temp_laps

precip_module and

temp module $=$ xyz_dist

precip_module and temp_module $=$ ide dist

recip_module $=$

precip_dist2 and/

or temp_module = temp_dist2

temp_module $=$ temp 2sta prms

precip_module $=$ precip_laps

precip_module $=$ precip_1sta or precip_laps

temp_module $=$ temp_laps

temp_module $=$ temp_1sta, temp_ laps, or temp_2sta prms 
Table 1-3. Parameters listed by usage with the associated modules in which they are used for the Precipitation-Runoff Modeling System, version 4 (PRMS-IV).-Continued

[HRU, hydrologic response unit; GWR, groundwater reservoir; cfs, cubic feet per second; cms, cubic meters per second; ET, evapotranspiration; dday, degree-day, the amount a day's average temperature departed from 65 degrees Fahrenheit; >, greater than; dimensions defined in table 1-1; control parameters temp_module, precip_module, solrad_module, et_module, transp_module, srunoff_module, strmflow_module, soilzone_module, model_mode, dprst_flag, subbasin_flag, cascade_flag, cascadegw_flag, and mapOutON_OFF defined in table 1-2. Note: modules soltab_prms, temp_2sta_prms, ccsolrad_prms, ddsolrad_prms, potet_hamon_prms, smbal_prms, ssflow_prms, and hru_sum_prms are deprecated and only included for backwards compatibility for PRMS models built prior to PRMS-IV]

\begin{tabular}{|c|c|c|c|c|c|c|c|}
\hline $\begin{array}{l}\text { Parameter } \\
\text { name }\end{array}$ & Description & Dimension $^{1}$ & Type & Units & Range & Default & Required/condition \\
\hline hru_x & Longitude $(\mathrm{X})$ for each HRU in albers projection & nhru & real & meters & $-1.0 \mathrm{E} 7$ to $1.0 \mathrm{E} 7$ & 0.0 & $\begin{array}{l}\text { precip_module and } \\
\text { temp_module }= \\
\text { ide_dist or xyz_dist }\end{array}$ \\
\hline hru_xlong & $\begin{array}{l}\text { Longitude of each HRU for the centroid, State } \\
\text { Plane Coordinate System }\end{array}$ & nhru & real & feet & $-1.0 \mathrm{E} 9$ to $1.0 \mathrm{E} 9$ & 0.0 & $\begin{array}{l}\text { temp_module } \\
=\text { temp_dist } 2 \text { or } \\
\text { precip_module }= \\
\text { precip_dist } 2\end{array}$ \\
\hline hru_y & Latitude (Y) for each HRU in albers projection & nhru & real & meters & $-1.0 \mathrm{E} 7$ to $1.0 \mathrm{E} 7$ & 0.0 & $\begin{array}{l}\text { precip_module and } \\
\text { temp_module }= \\
\text { ide_dist or xyz_dist }\end{array}$ \\
\hline hru_ylat & $\begin{array}{l}\text { Latitude of each HRU for the centroid, State } \\
\text { Plane Coordinate System }\end{array}$ & nhru & real & feet & $-1.0 \mathrm{E} 9$ to $1.0 \mathrm{E} 9$ & 0.0 & $\begin{array}{l}\text { temp_module }= \\
\text { temp_dist } 2 \text { and } / \text { or } \\
\text { precip_module }= \\
\text { precip_dist } 2\end{array}$ \\
\hline lapsemax_max & $\begin{array}{l}\text { Monthly (January to December) maximum lapse } \\
\text { rate to constrain lowest maximum lapse rate } \\
\text { based on historical daily air temperatures for all } \\
\text { air temperature-measurement stations }\end{array}$ & nmonths & real & temp_units/ feet & -3.0 to 3.0 & 2.0 & $\begin{array}{l}\text { temp_module }= \\
\text { temp_dist } 2\end{array}$ \\
\hline lapsemax_min & $\begin{array}{l}\text { Monthly (January to December) maximum lapse } \\
\text { rate to constrain lowest minimum lapse rate on } \\
\text { the basis of historical daily air temperatures for } \\
\text { all air temperature-measurement stations }\end{array}$ & nmonths & real & temp_units/ feet & -7.0 to -3.0 & -6.5 & $\begin{array}{l}\text { temp_module }= \\
\text { temp_dist } 2\end{array}$ \\
\hline lapsemin_max & $\begin{array}{l}\text { Monthly (January to December) minimum lapse } \\
\text { rate to constrain lowest maximum lapse rate on } \\
\text { the basis of historical daily air temperatures for } \\
\text { all air temperature-measurement stations }\end{array}$ & nmonths & real & temp_units/feet & -2.0 to 4.0 & 3.0 & $\begin{array}{l}\text { temp_module }= \\
\text { temp_dist } 2\end{array}$ \\
\hline lapsemin_min & $\begin{array}{l}\text { Monthly (January to December) minimum lapse } \\
\text { rate to constrain lowest minimum lapse rate on } \\
\text { the basis of historical daily air temperatures for } \\
\text { all air temperature-measurement stations }\end{array}$ & nmonths & real & temp_units/feet & -7.0 to -3.0 & -4.0 & $\begin{array}{l}\text { temp_module }= \\
\text { temp_dist } 2\end{array}$ \\
\hline lo_index & $\begin{array}{l}\text { Index of lower temperature station for daily lapse } \\
\text { rate computations }\end{array}$ & one & integer & none & 1 to $n$ temp & 1 & $\begin{array}{l}\text { temp_module }= \\
\text { temp_2sta_prms }\end{array}$ \\
\hline max_lapse & $\begin{array}{l}\text { Monthly (January to December) maximum air } \\
\text { temperature lapse rate for each direction (X, Y, } \\
\text { and Z) ) }\end{array}$ & $\begin{array}{l}\text { nlapse, } \\
\text { nmonths }\end{array}$ & real & none & -100.0 to 100.0 & 0.0 & $\begin{array}{l}\text { temp_module }= \\
\quad x y z \_d i s t\end{array}$ \\
\hline
\end{tabular}


[HRU, hydrologic response unit; GWR, groundwater reservoir; cfs, cubic feet per second; cms, cubic meters per second; ET, evapotranspiration; dday, degree-day, the amount a day's average temperature departed from 65 degrees Fahrenheit; >, greater than; dimensions defined in table 1-1; control parameters temp_module, precip_module, solrad_module, et_module, transp_module, srunoff_module, strmflow module, soilzone module, model mode, dprst flag, subbasin flag, cascade flag, cascadegw flag, and mapOutON OFF defined in table 1-2. Note: modules soltab prms, temp 2sta prms, ccsolrad_prms, ddsolrad_prms, potet_hamon_prms, smbal_prms, ssflow_prms, and hru_sum_prms are deprecated and only included for backwards compatibility for PRMS models built prior to PRMS-IV]

\begin{tabular}{|c|c|c|c|c|c|c|c|}
\hline $\begin{array}{l}\text { Parameter } \\
\text { name }\end{array}$ & Description & Dimension $^{1}$ & Type & Units & Range & Default & Required/condition \\
\hline max_missing & $\begin{array}{l}\text { Maximum number of consecutive missing values } \\
\text { allowed for any air temperature measurement } \\
\text { station; missing value set to last valid value; } \\
0=\text { unlimited }\end{array}$ & one & integer & none & 0 to 10 & 3 & $\begin{array}{l}\text { temp_module } \\
=\text { temp_1sta or } \\
\text { temp_laps }\end{array}$ \\
\hline max_psta & $\begin{array}{l}\text { Maximum number of precipitation measurement } \\
\text { stations to distribute to an HRU }\end{array}$ & one & integer & none & 2 to nrain & 50 & $\begin{array}{l}\text { precip_module }= \\
\text { precip_dist } 2\end{array}$ \\
\hline max_tsta & $\begin{array}{l}\text { Maximum number of air temperature measure- } \\
\text { ment stations to use for distributing tempera- } \\
\text { ture to any HRU }\end{array}$ & one & integer & none & 2 to ntemp & 50 & $\begin{array}{l}\text { temp_module }= \\
\text { temp_dist } 2\end{array}$ \\
\hline maxday_prec & $\begin{array}{l}\text { Maximum measured precipitation value above } \\
\text { which precipitation is assumed to be in error }\end{array}$ & one & real & precip_units & 0.0 to 20.0 & 15.0 & $\begin{array}{l}\text { precip_module }= \\
\text { precip_dist } 2\end{array}$ \\
\hline min_lapse & $\begin{array}{l}\text { Monthly (January to December) minimum air } \\
\text { temperature lapse rate for each direction (X, Y, } \\
\text { and Z) }\end{array}$ & $\begin{array}{l}\text { nlapse, } \\
\text { nmonths }\end{array}$ & real & none & -100.0 to 100.0 & 0.0 & $\begin{array}{l}\text { temp_module }= \\
\text { xyz_dist }\end{array}$ \\
\hline monmax & $\begin{array}{l}\text { Monthly maximum air temperature to constrain } \\
\text { lowest maximum air temperatures for bad } \\
\text { values on the basis of historical temperature for } \\
\text { all measurement stations }\end{array}$ & nmonths & real & temp_units & 0.0 to 115.0 & 100.0 & $\begin{array}{l}\text { temp_module }= \\
\text { temp_dist } 2\end{array}$ \\
\hline monmin & $\begin{array}{l}\text { Monthly minimum air temperature to constrain } \\
\text { lowest maximum air temperatures for bad } \\
\text { values on the basis of historical temperature for } \\
\text { all measurement stations }\end{array}$ & nmonths & real & temp_units & -60.0 to 65.0 & -60.0 & $\begin{array}{l}\text { temp_module }= \\
\text { temp_dist } 2\end{array}$ \\
\hline ndist_psta & $\begin{array}{l}\text { Number of precipitation measure stations for } \\
\text { inverse distance calculations }\end{array}$ & one & integer & none & 1 to nrain & 3 & $\begin{array}{l}\text { precip_module } \\
\text { ide_dist }\end{array}$ \\
\hline ndist_tsta & $\begin{array}{l}\text { Number of air temperature-measurement stations } \\
\text { for inverse distance calculations }\end{array}$ & one & integer & none & 1 to ntemp & 3 & $\begin{array}{l}\text { temp_module }= \\
\text { ide_dist }\end{array}$ \\
\hline padj_rn & $\begin{array}{l}\text { Monthly (January to December) factor to adjust } \\
\text { precipitation lapse rate computed between sta- } \\
\text { tion hru_psta and station hru_plaps; positive } \\
\text { factors are multiplied times the lapse rate and } \\
\text { negative factors are made positive and substi- } \\
\text { tuted for the computed lapse rate }\end{array}$ & $\begin{array}{l}\text { nrain, } \\
\text { nmonths }\end{array}$ & real & precip_units & -2.0 to 10.0 & 1.0 & $\begin{array}{l}\text { precip_module }= \\
\text { precip_laps }\end{array}$ \\
\hline padj_sn & $\begin{array}{l}\text { Monthly (January to December) factor to adjust } \\
\text { precipitation lapse rate computed between sta- }\end{array}$ & $\begin{array}{l}\text { nrain, } \\
\text { nmonths }\end{array}$ & real & precip_units & -2.0 to 10.0 & 1.0 & $\begin{array}{l}\text { precip_module }= \\
\text { precip_laps }\end{array}$ \\
\hline
\end{tabular}
tion hru_psta and station hru_plaps; positive factors are multiplied times the lapse rate and negative factors are made positive and substituted for the computed lapse rate 
Table 1-3. Parameters listed by usage with the associated modules in which they are used for the Precipitation-Runoff Modeling System, version 4 (PRMS-IV).-Continued

[HRU, hydrologic response unit; GWR, groundwater reservoir; cfs, cubic feet per second; cms, cubic meters per second; ET, evapotranspiration; dday, degree-day, the amount a day's average temperature departed from 65 degrees Fahrenheit; >, greater than; dimensions defined in table 1-1; control parameters temp_module, precip_module, solrad_module, et_module, transp_module, srunoff_module, strmflow_module, soilzone_module, model_mode, dprst_flag, subbasin_flag, cascade_flag, cascadegw_flag, and mapOutON_OFF defined in table 1-2. Note: modules soltab_prms, temp_2sta_prms, ccsolrad_prms, ddsolrad_prms, potet_hamon_prms, smbal_prms, ssflow_prms, and hru_sum_prms are deprecated and only included for backwards compatibility for PRMS models built prior to PRMS-IV]

\begin{tabular}{|c|c|c|c|c|c|c|c|}
\hline $\begin{array}{l}\text { Parameter } \\
\text { name }\end{array}$ & Description & Dimension $^{1}$ & Type & Units & Range & Default & Required/condition \\
\hline pmn_mo & $\begin{array}{l}\text { Mean monthly (January to December) precipita- } \\
\text { tion for each lapse precipitation measurement } \\
\text { station }\end{array}$ & $\begin{array}{l}\text { nrain, } \\
\text { nmonths }\end{array}$ & real & precip_units & 0.00001 to 100.0 & 1.0 & $\begin{array}{l}\text { precip_module }= \\
\text { precip_laps }\end{array}$ \\
\hline ppt_add & $\begin{array}{l}\text { Mean value for the precipitation measurement } \\
\text { station transformation equation }\end{array}$ & one & real & precip_units & -10.0 to 10.0 & 0.0 & $\begin{array}{l}\text { precip_module } \\
\quad \text { xyz_dist }\end{array}$ \\
\hline ppt_div & $\begin{array}{l}\text { Standard deviation for the precipitation measure- } \\
\text { ment station transformation equation (not } 0.0 \text { ) }\end{array}$ & one & real & precip_units & -10.0 to 10.0 & 0.0 & $\begin{array}{l}\text { precip_module } \\
\quad \text { xyz_dist }\end{array}$ \\
\hline ppt_lapse & $\begin{array}{l}\text { Monthly (January to December) precipitation } \\
\text { lapse rate for each direction (X, Y, and Z) }\end{array}$ & $\begin{array}{l}\text { nlapse, } \\
\text { nmonths }\end{array}$ & real & none & -10.0 to 10.0 & 0.0 & $\begin{array}{l}\text { precip_module } \\
\quad \text { xyz_dist }\end{array}$ \\
\hline prep_wght_dist & $\begin{array}{l}\text { Monthly (January to December) precipitation } \\
\text { weighting function for inverse distance calcula- } \\
\text { tions }\end{array}$ & nmonths & real & decimal fraction & 0.0 to 1.0 & 0.5 & $\begin{array}{l}\text { precip_module }= \\
\text { ide_dist }\end{array}$ \\
\hline psta_elev & $\begin{array}{l}\text { Elevation of each precipitation measurement } \\
\text { station }\end{array}$ & nrain & real & elev_units & -300.0 to $30,000.0$ & 0.0 & $\begin{array}{l}\text { precip_module }= \\
\text { ide_dist, xyz_dist, or } \\
\quad \text { precip_laps }\end{array}$ \\
\hline psta_freq_nuse & $\begin{array}{l}\text { The subset of precipitation measurement stations } \\
\text { used to determine if there is precipitation in the } \\
\text { basin }(0=\text { station not used; } 1=\text { station used })\end{array}$ & nrain & integer & none & 0 or 1 & 1 & $\begin{array}{l}\text { precip_module } \\
\quad \text { xyz_dist }\end{array}$ \\
\hline psta_mon & $\begin{array}{l}\text { Monthly (January to December) factor to precipi- } \\
\text { tation at each measured station to adjust pre- } \\
\text { cipitation distributed to each HRU to account } \\
\text { for differences in elevation, and so forth) }\end{array}$ & $\begin{array}{l}\text { nrain, } \\
\text { nmonths }\end{array}$ & real & precip_units & 0.00001 to 50.0 & 1.0 & $\begin{array}{l}\text { precip_module }= \\
\text { precip_dist } 2\end{array}$ \\
\hline psta_month_ppt & $\begin{array}{l}\text { Average monthly (January to December) } \\
\text { maximum precipitation at each precipitation } \\
\text { measurement station }\end{array}$ & $\begin{array}{l}\text { nrain, } \\
\text { nmonths }\end{array}$ & real & precip_units & 0.0 to 20.0 & 0.0 & $\begin{array}{l}\text { precip_module } \\
\quad \text { xyz_dist }\end{array}$ \\
\hline psta_nuse & $\begin{array}{l}\text { The subset of precipitation measurement stations } \\
\text { used in the distribution regression }(0=\text { station } \\
\text { not used; } 1=\text { station used })\end{array}$ & nrain & integer & none & 0 or 1 & 1 & $\begin{array}{l}\text { precip_module }= \\
\text { ide_dist or xyz_dist }\end{array}$ \\
\hline psta_x & $\begin{array}{l}\text { Longitude }(\mathrm{X}) \text { for each precipitation measurement } \\
\text { station in albers projection }\end{array}$ & nrain & real & meters & $-1.0 \mathrm{E} 7$ to $1.0 \mathrm{E} 7$ & 0 & $\begin{array}{l}\text { precip_module }= \\
\text { ide_dist or xyz_dist }\end{array}$ \\
\hline psta_xlong & $\begin{array}{l}\text { Longitude of each precipitation measurement sta- } \\
\text { tion, State Plane Coordinate System }\end{array}$ & nrain & real & feet & $-1.0 \mathrm{E} 9$ to $1.0 \mathrm{E} 9$ & 0.0 & $\begin{array}{l}\text { precip_module }= \\
\text { precip_dist } 2\end{array}$ \\
\hline psta_y & $\begin{array}{l}\text { Latitude }(\mathrm{Y}) \text { for each precipitation measurement } \\
\text { station in albers projection }\end{array}$ & nrain & real & meters & $-1.0 \mathrm{E} 7$ to $1.0 \mathrm{E} 7$ & 0 & $\begin{array}{l}\text { precip_module }= \\
\text { ide_dist or xyz_dist }\end{array}$ \\
\hline
\end{tabular}


Table 1-3. Parameters listed by usage with the associated modules in which they are used for the Precipitation-Runoff Modeling System, version 4 (PRMS-IV).-CContinued

[HRU, hydrologic response unit; GWR, groundwater reservoir; cfs, cubic feet per second; cms, cubic meters per second; ET, evapotranspiration; dday, degree-day, the amount a day's average temperature departed from 65 degrees Fahrenheit; >, greater than; dimensions defined in table 1-1; control parameters temp_module, precip_module, solrad_module, et_module, transp_module, srunoff_module, strmflow module, soilzone module, model mode, dprst flag, subbasin flag, cascade flag, cascadegw flag, and mapOutON OFF defined in table 1-2. Note: modules soltab prms, temp 2sta prms, ccsolrad_prms, ddsolrad_prms, potet_hamon_prms, smbal_prms, ssflow_prms, and hru_sum_prms are deprecated and only included for backwards compatibility for PRMS models built prior to PRMS-IV]

\begin{tabular}{|c|c|c|c|c|c|c|c|}
\hline $\begin{array}{c}\text { Parameter } \\
\text { name }\end{array}$ & Description & Dimension $^{1}$ & Type & Units & Range & Default & Required/condition \\
\hline
\end{tabular}

psta_ylat

Latitude of each precipitation measurement station, State Plane Coordinate System

rain_adj

Monthly (January to December) factor to adjust measured precipitation on each HRU to account for differences in elevation, and so forth

rain_cbh_adj

Monthly (January to December) adjustment factor to measured precipitation on each HRU to account for differences in elevation, and so forth; used if control parameter

rain mon

Monthly (January to December) factor to rain on each HRU to adjust precipitation distributed to each HRU to account for differences in elevation, and so forth

rain_sub_ad

Monthly (January to December) rain adjustment factor to measured precipitation for each subbasin

snow_adj

Monthly (January to December) factor to adjust measured precipitation on each HRU to account for differences in elevation, and so forth

snow_cbh_adj

Monthly (January to December) adjustment factor to measured precipitation on each HRU to account for differences in elevation, and so forth

snow_mon

Monthly (January to December) factor to snow on each HRU to adjust precipitation distributed to each HRU to account for differences in elevation, and so forth

snow_sub_adj

Monthly (January to December) snow adjustment factor to measured precipitation for each subbasin

solrad_elev

Elevation of the solar radiation station used for the degree-day curves to distribute temerature

temp_wght_dist

nm

nhru,
nmonths real $\quad$ precip_units 0.0 to $50.0 \quad 1.0 \quad \begin{gathered}\text { precip_module }= \\ \text { precip_dist2 }\end{gathered}$

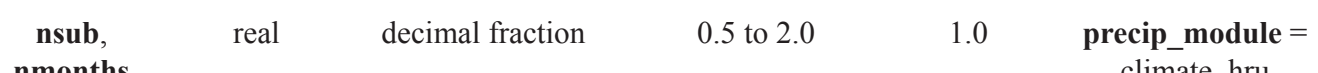

nmonths

real

feet

$-1.0 \mathrm{E} 9$ to $1.0 \mathrm{E} 9$

1.0 precip_dist2

nhru,

real decimal fraction

0.5 to 2.0

recip_module $=$

nhru, real decimal fraction 0.5 to $2.0 \quad 1.0 \quad$ precip_module $=$

nmonths

nhru,

real

decimal fraction

0.5 to 2.0

\section{nhru,}

nmonths

real

decimal fraction

0.5 to 2.0

nhru,

nmonths

real

precip_units

0.0 to 50.0

nsub,

decimal fraction

0.5 to 2.0

nmonths

one

real

elev_units

-300.0 to $30,000.0$

0.0

nmonths

real

decimal fraction

0.0 to 1.0

0.5

weighting function for inverse distance calculations) 
Table 1-3. Parameters listed by usage with the associated modules in which they are used for the Precipitation-Runoff Modeling System, version 4 (PRMS-IV).-Continued

[HRU, hydrologic response unit; GWR, groundwater reservoir; cfs, cubic feet per second; cms, cubic meters per second; ET, evapotranspiration; dday, degree-day, the amount a day's average temperature departed from 65 degrees Fahrenheit; >, greater than; dimensions defined in table 1-1; control parameters temp_module, precip_module, solrad_module, et_module, transp_module, srunoff_module, strmflow_module, soilzone_module, model_mode, dprst_flag, subbasin_flag, cascade_flag, cascadegw_flag, and mapOutON_OFF defined in table 1-2. Note: modules soltab_prms, temp_2sta_prms, ccsolrad prms, ddsolrad prms, potet hamon prms, smbal prms, ssflow prms, and hru sum prms are deprecated and only included for backwards compatibility for PRMS models built prior to PRMS-IV

\begin{tabular}{|c|c|c|c|c|c|c|c|}
\hline $\begin{array}{l}\text { Parameter } \\
\text { name }\end{array}$ & Description & Dimension $^{1}$ & Type & Units & Range & Default & Required/condition \\
\hline tmax_add & $\begin{array}{l}\text { Mean value for the air-temperature measurement } \\
\text { station transformation equation for maximum } \\
\text { air temperature }\end{array}$ & one & real & temp_units & -100.0 to 100.0 & 0.0 & $\begin{array}{l}\text { temp_module } \\
\text { xyz_dist }\end{array}$ \\
\hline tmax_adj & $\begin{array}{l}\text { Adjustment to maximum air temperature for } \\
\text { each HRU, estimated on the basis of slope and } \\
\text { aspect }\end{array}$ & nhru & real & temp_units & -10.0 to 10.0 & 0.0 & $\begin{array}{c}\text { temp_module } \\
=\text { temp_1sta, } \\
\text { temp_2sta_prms, } \\
\text { temp_dist2, temp_ } \\
\text { laps, ide_dist or } \\
\text { xyz_dist }\end{array}$ \\
\hline tmax_allrain & $\begin{array}{l}\text { Monthly (January to December) maximum air } \\
\text { temperature when precipitation is assumed to } \\
\text { be rain; if HRU air temperature is greater than } \\
\text { or equal to this value, precipitation is rain }\end{array}$ & nmonths & real & temp_units & -8.0 to 60.0 & 38.0 & required \\
\hline tmax_allsnow & $\begin{array}{l}\text { Monthly (January to December) maximum air } \\
\text { temperature when precipitation is assumed to } \\
\text { be snow; if HRU air temperature is less than or } \\
\text { equal to this value, precipitation is snow }\end{array}$ & one & real & temp_units & -10.0 to 40.0 & 32.0 & required \\
\hline tmax_cbh_adj & $\begin{array}{l}\text { Adjustment to maximum air temperature for each } \\
\text { HRU, estimated based on slope and aspect }\end{array}$ & nhru & real & temp_units & -10.0 to 10.0 & 0.0 & $\begin{array}{l}\text { temp_module }= \\
\text { climate_hru }\end{array}$ \\
\hline tmax_div & $\begin{array}{l}\text { Standard deviation for the air-temperature-mea- } \\
\text { surement station transformation equation for } \\
\text { maximum air temperature (not } 0.0 \text { ) }\end{array}$ & one & real & temp_units & -100.0 to 100.0 & 0.0 & $\begin{array}{l}\text { temp_module } \\
\text { xyz_dist }\end{array}$ \\
\hline tmax_lapse & $\begin{array}{l}\text { Monthly (January to December) values represent- } \\
\text { ing the change in maximum air temperature per } \\
1,000 \text { elev_units of elevation change }\end{array}$ & nmonths & real & $\begin{array}{l}\text { temp_units/ } \\
\text { elev_units }\end{array}$ & -10.0 to 10.0 & 3.0 & $\begin{array}{l}\text { temp_module }= \\
\text { temp_1sta }\end{array}$ \\
\hline tmax_mo_adj & $\begin{array}{l}\text { Monthly (January to December) adjustment factor } \\
\text { to maximum air temperature for each HRU, } \\
\text { estimated on the basis of slope and aspect }\end{array}$ & $\begin{array}{l}\text { nhru, } \\
\text { nmonths }\end{array}$ & real & temp_units & -10.0 to 10.0 & 0.0 & $\begin{array}{l}\text { temp_module }= \\
\text { temp_dist } 2\end{array}$ \\
\hline tmin_add & $\begin{array}{l}\text { Mean value for the air-temperature-measurement } \\
\text { station transformation equation for minimum }\end{array}$ & one & real & temp_units & -100.0 to 100.0 & 0.0 & $\underset{\text { xyz_dist }}{\text { temp_module }}=$ \\
\hline
\end{tabular}


Table 1-3. Parameters listed by usage with the associated modules in which they are used for the Precipitation-Runoff Modeling System, version 4 (PRMS-IV).—Continued

[HRU, hydrologic response unit; GWR, groundwater reservoir; cfs, cubic feet per second; cms, cubic meters per second; ET, evapotranspiration; dday, degree-day, the amount a day's average temperature departed from 65 degrees Fahrenheit; >, greater than; dimensions defined in table 1-1; control parameters temp_module, precip_module, solrad_module, et_module, transp_module, srunoff_module, strmflow module, soilzone module, model_mode, dprst flag, subbasin flag, cascade flag, cascadegw flag, and mapOutON OFF defined in table 1-2. Note: modules soltab prms, temp 2sta prms, ccsolrad_prms, ddsolrad_prms, potet_hamon_prms, smbal_prms, ssflow_prms, and hru_sum_prms are deprecated and only included for backwards compatibility for PRMS models built prior to PRMS-IV]

\begin{tabular}{|c|c|c|c|c|c|c|c|}
\hline $\begin{array}{c}\text { Parameter } \\
\text { name }\end{array}$ & Description & Dimension' 1 & Type & Units & Range & Default & Required/condition \\
\hline tmin_adj & $\begin{array}{l}\text { Adjustment to minimum air temperature for } \\
\text { each HRU, estimated on the basis of slope and } \\
\text { aspect }\end{array}$ & nhru & real & temp_units & -10.0 to 10.0 & 0.0 & $\begin{array}{l}\text { temp_module } \\
\text { = temp_1sta, } \\
\text { temp_2sta_prms, } \\
\text { temp_dist2, temp_ } \\
\text { laps, ide_dist or } \\
\text { xyz_dist }\end{array}$ \\
\hline tmin_cbh_adj & $\begin{array}{l}\text { Adjustment to minimum air temperature for each } \\
\text { HRU, estimated based on slope and aspect }\end{array}$ & nhru & real & temp_units & -10.0 to 10.0 & 0.0 & $\begin{array}{l}\text { temp_module }= \\
\text { climate_hru }\end{array}$ \\
\hline tmin_div & $\begin{array}{l}\text { Standard deviation for the air-temperature-mea- } \\
\text { surement station transformation equation for } \\
\text { minimum air temperature (not } 0.0 \text { ) }\end{array}$ & one & real & temp_units & -100.0 to 100.0 & 0.0 & $\begin{array}{l}\text { temp_module } \\
\text { xyz_dist }\end{array}$ \\
\hline tmin_lapse & $\begin{array}{l}\text { Monthly (January to December) values represent- } \\
\text { ing the change in minimum air temperature per } \\
1,000 \text { elev_units of elevation change }\end{array}$ & nmonths & real & $\begin{array}{l}\text { temp_units/ } \\
\text { elev_units }\end{array}$ & -10.0 to 10.0 & 3.0 & $\begin{array}{l}\text { temp_module }= \\
\text { temp_1sta }\end{array}$ \\
\hline tmin_mo_adj & $\begin{array}{l}\text { Monthly (January to December) adjustment factor } \\
\text { to minimum air temperature for each HRU, } \\
\text { estimated on the basis of slope and aspect }\end{array}$ & $\begin{array}{l}\text { nhru, } \\
\text { nmonths }\end{array}$ & real & temp_units & -10.0 to 10.0 & 0.0 & $\begin{array}{l}\text { temp_module }= \\
\text { temp_dist } 2\end{array}$ \\
\hline tsta_elev & $\begin{array}{l}\text { Elevation of each air-temperature-measurement } \\
\text { station }\end{array}$ & ntemp & real & elev_units & -300.0 to $30,000.0$ & 0.0 & $\begin{array}{l}\text { temp_module } \\
=\text { temp_1sta, } \\
\text { temp_2sta_prms, } \\
\text { temp_dist2, temp_ } \\
\text { laps, ide_dist or } \\
\text { xyz_dist }\end{array}$ \\
\hline tsta_month_max & $\begin{array}{l}\text { Average monthly (January to December) maxi- } \\
\text { mum air temperature at each air-temperature- } \\
\text { measurement station }\end{array}$ & $\begin{array}{l}\text { ntemp, } \\
\text { nmonths }\end{array}$ & real & temp_units & -100.0 to 100.0 & 0.0 & $\begin{array}{l}\text { temp_module } \\
\text { xyz_dist }\end{array}$ \\
\hline tsta_month_min & $\begin{array}{l}\text { Average monthly (January to December) mini- } \\
\text { mum air temperature at each air-temperature- } \\
\text { measurement station }\end{array}$ & $\begin{array}{l}\text { ntemp, } \\
\text { nmonths }\end{array}$ & real & temp_units & -100.0 to 100.0 & 0.0 & $\begin{array}{l}\text { temp_module } \\
\text { xyz_dist }\end{array}$ \\
\hline tsta_nuse & $\begin{array}{l}\text { The subset of temperature stations used in the } \\
\text { distribution regression }(0=\text { station not used; } \\
1=\text { station used })\end{array}$ & ntemp & integer & none & 0 or 1 & 1 & $\begin{array}{l}\text { temp_module }= \\
\text { ide_dist or xyz_dist }\end{array}$ \\
\hline tsta_x & $\begin{array}{l}\text { Longitude }(\mathrm{X}) \text { for each air temperature- } \\
\text { measurement station in albers projection }\end{array}$ & ntemp & real & meters & $-1.0 \mathrm{E} 7$ to $1.0 \mathrm{E} 7$ & 0.0 & $\begin{array}{l}\text { temp_module }= \\
\text { ide_dist or xyz_dist }\end{array}$ \\
\hline tsta_xlong & $\begin{array}{l}\text { Longitude of each temperature-measurement sta- } \\
\text { tion, State Plane Coordinate System }\end{array}$ & ntemp & real & feet & $-1.0 \mathrm{E} 9$ to $1.0 \mathrm{E} 9$ & 0.0 & $\begin{array}{l}\text { temp_module }= \\
\text { temp_dist } 2\end{array}$ \\
\hline
\end{tabular}


Table 1-3. Parameters listed by usage with the associated modules in which they are used for the Precipitation-Runoff Modeling System, version 4 (PRMS-IV).-Continued

[HRU, hydrologic response unit; GWR, groundwater reservoir; cfs, cubic feet per second; cms, cubic meters per second; ET, evapotranspiration; dday, degree-day, the amount a day's average temperature departed from 65 degrees Fahrenheit; >, greater than; dimensions defined in table 1-1; control parameters temp_module, precip_module, solrad_module, et_module, transp_module, srunoff_module, strmflow_module, soilzone_module, model_mode, dprst_flag, subbasin_flag, cascade_flag, cascadegw_flag, and mapOutON_OFF defined in table 1-2. Note: modules soltab_prms, temp_2sta_prms, ccsolrad_prms, ddsolrad_prms, potet_hamon_prms, smbal_prms, ssflow_prms, and hru_sum_prms are deprecated and only included for backwards compatibility for PRMS models built prior to PRMS-IV]

\begin{tabular}{|c|c|c|c|c|c|c|c|}
\hline $\begin{array}{l}\text { Parameter } \\
\text { name }\end{array}$ & Description & Dimension' & Type & Units & Range & Default & Required/condition \\
\hline tsta_y & $\begin{array}{l}\text { Latitude }(\mathrm{Y}) \text { for each air-temperature-measure- } \\
\text { ment station in albers projection }\end{array}$ & ntemp & real & meters & $-1.0 \mathrm{E} 7$ to $1.0 \mathrm{E} 7$ & 0.0 & $\begin{array}{l}\text { temp_module }= \\
\text { ide_dist or xyz_dist }\end{array}$ \\
\hline tsta_ylat & $\begin{array}{l}\text { Latitude of each temperature-measurement sta- } \\
\text { tion, State Plane Coordinate System }\end{array}$ & ntemp & real & feet & $-1.0 \mathrm{E} 9$ to $1.0 \mathrm{E} 9$ & 0.0 & $\begin{array}{l}\text { temp_module }= \\
\text { temp_dist2 }\end{array}$ \\
\hline x_add & $\begin{array}{l}\text { Mean value for the climate station transformation } \\
\text { equation for the longitude }(\mathrm{X}) \text { coordinate }\end{array}$ & one & real & meters & $-1.0 \mathrm{E} 7$ to $1.0 \mathrm{E} 7$ & 0.0 & $\begin{array}{l}\text { precip_module and } \\
\text { temp_module }= \\
\text { xyz_dist }\end{array}$ \\
\hline x_div & $\begin{array}{l}\text { Standard deviation for the climate station } \\
\text { transformation equation for the longitude }(\mathrm{X}) \\
\text { coordinate (not } 0.0 \text { ) }\end{array}$ & one & real & meters & $-1.0 \mathrm{E} 7$ to $1.0 \mathrm{E} 7$ & 0.0 & $\begin{array}{l}\text { precip_module and } \\
\text { temp_module }= \\
\text { xyz_dist }\end{array}$ \\
\hline y_add & $\begin{array}{l}\text { Mean value for the climate station transformation } \\
\text { equation for the latitude }(\mathrm{Y}) \text { coordinate }\end{array}$ & one & real & meters & $-1.0 \mathrm{E} 7$ to $1.0 \mathrm{E} 7$ & 0.0 & $\begin{array}{l}\text { precip_module and } \\
\text { temp_module }= \\
\text { xyz_dist }\end{array}$ \\
\hline y_div & $\begin{array}{l}\text { Standard deviation for the climate station } \\
\text { transformation equation for the latitude }(\mathrm{Y}) \\
\text { coordinate }\end{array}$ & one & real & meters & $-1.0 \mathrm{E} 7$ to $1.0 \mathrm{E} 7$ & 0.0 & $\begin{array}{l}\text { precip_module and } \\
\text { temp_module }= \\
\text { xyz_dist }\end{array}$ \\
\hline$z_{-}$add & $\begin{array}{l}\text { Mean value for the climate station transformation } \\
\text { equation for the elevation }(\mathrm{Z}) \text { coordinate }\end{array}$ & one & real & meters & $-1.0 \mathrm{E} 7$ to $1.0 \mathrm{E} 7$ & 0.0 & $\begin{array}{l}\text { precip_module and } \\
\text { temp_module }= \\
\text { xyz_dist }\end{array}$ \\
\hline$z_{-}$div & $\begin{array}{l}\text { Standard deviation for the climate station } \\
\text { transformation equation for the elevation }(\mathrm{Z}) \\
\text { coordinate (not } 0.0 \text { ) }\end{array}$ & one & real & meters & $-1.0 \mathrm{E} 7$ to $1.0 \mathrm{E} 7$ & 0.0 & $\begin{array}{l}\text { precip_module and } \\
\text { temp_module }= \\
\text { xyz_dist }\end{array}$ \\
\hline \multicolumn{8}{|c|}{ Solar radiation } \\
\hline basin_solsta & $\begin{array}{l}\text { Index of solar radiation station used to compute } \\
\text { basin radiation values; used when dimension } \\
\text { nsol }>0\end{array}$ & one & integer & none & 0 to nsol & 0 & nsol $>0$ \\
\hline ccov_intep & $\begin{array}{l}\text { Monthly (January to December) intercept in } \\
\text { cloud-cover relationship }\end{array}$ & nmonths & real & none & 0.0 to 5.0 & 1.83 & $\begin{array}{l}\text { solrad_module }= \\
\text { ccsolrad or ccsol- } \\
\quad \text { rad_prms }\end{array}$ \\
\hline ccov_slope & $\begin{array}{l}\text { Monthly (January to December) coefficient in } \\
\text { cloud-cover relationship; used if control param- } \\
\text { eter solrad_module=ccsolrad or ccsolrad_prms }\end{array}$ & nmonths & real & none & -0.5 to -0.01 & -0.13 & $\begin{array}{l}\text { solrad_module }= \\
\text { ccsolrad or ccsol- } \\
\quad \text { rad_prms }\end{array}$ \\
\hline crad_coef & $\begin{array}{l}\text { Coefficient(B) in Thompson (1976) equation; } \\
\text { varies by region, contour map of values in } \\
\text { reference }\end{array}$ & one & real & none & 0.1 to 0.7 & 0.4 & $\begin{array}{l}\text { solrad_module }= \\
\text { ccsolrad or ccsol- } \\
\quad \text { rad_prms }\end{array}$ \\
\hline
\end{tabular}


Table 1-3. Parameters listed by usage with the associated modules in which they are used for the Precipitation-Runoff Modeling System, version 4 (PRMS-IV).—Continued

[HRU, hydrologic response unit; GWR, groundwater reservoir; cfs, cubic feet per second; cms, cubic meters per second; ET, evapotranspiration; dday, degree-day, the amount a day's average temperature departed from 65 degrees Fahrenheit; >, greater than; dimensions defined in table 1-1; control parameters temp_module, precip_module, solrad_module, et_module, transp_module, srunoff_module, strmflow module, soilzone module, model_mode, dprst flag, subbasin flag, cascade flag, cascadegw flag, and mapOutON OFF defined in table 1-2. Note: modules soltab prms, temp 2sta prms, ccsolrad_prms, ddsolrad_prms, potet_hamon_prms, smbal_prms, ssflow_prms, and hru_sum_prms are deprecated and only included for backwards compatibility for PRMS models built prior to PRMS-IV]

\begin{tabular}{|c|c|c|c|c|c|c|c|}
\hline $\begin{array}{l}\text { Parameter } \\
\text { name }\end{array}$ & Description & Dimension' ${ }^{1}$ & Type & Units & Range & Default & Required/condition \\
\hline crad_exp & Exponent(P) in Thompson (1976) equation & one & real & none & 0.2 to 0.8 & 0.61 & $\begin{array}{l}\text { solrad_module }= \\
\text { ccsolrad or ccsol- } \\
\quad \text { rad_prms }\end{array}$ \\
\hline dday_intcp & $\begin{array}{l}\text { Monthly (January to December) intercept in } \\
\text { degree-day equation }\end{array}$ & nmonths & real & dday & -60.0 to 10.0 & -40.0 & $\begin{array}{l}\text { solrad_module = } \\
\text { ddsolrad or ddsol- } \\
\quad \text { rad_prms }\end{array}$ \\
\hline dday_slope & $\begin{array}{l}\text { Monthly (January to December) slope in } \\
\text { degree-day equation }\end{array}$ & nmonths & real & dday/temp_units & 0.2 to 0.9 & 0.4 & $\begin{array}{l}\text { solrad_module = } \\
\text { ddsolrad or ddsol- } \\
\quad \text { rad_prms }\end{array}$ \\
\hline hru_solsta & $\begin{array}{l}\text { Index of solar radiation station associated with } \\
\text { each HRU }\end{array}$ & nhru & integer & none & 0 to $\mathbf{n s o l}$ & 0 & nsol $>0$ \\
\hline ppt_rad_adj & $\begin{array}{l}\text { Monthly minimum precipitation, if basin precipi- } \\
\text { tation exceeds this value, radiation is multi- } \\
\text { plied by radj_sppt or radj_wppt precipitation } \\
\text { adjustment factor }\end{array}$ & nmonths & real & inches & 0.0 to 0.5 & 0.02 & required \\
\hline radadj_intcp & $\begin{array}{l}\text { Intercept in air temperature range adjustment to } \\
\text { solar radiation equation }\end{array}$ & one & real & dday & 0.0 to 1.0 & 1.0 & $\begin{array}{l}\text { solrad_module = } \\
\text { ddsolrad or ddsol- } \\
\quad \text { rad_prms }\end{array}$ \\
\hline radadj_slope & $\begin{array}{l}\text { Slope in air temperature range adjustment to } \\
\text { degree-day equation }\end{array}$ & one & real & dday/temp_units & 0.0 to 1.0 & 0.0 & $\begin{array}{l}\text { solrad_module = } \\
\text { ddsolrad or ddsol- } \\
\quad \text { rad_prms }\end{array}$ \\
\hline radj_sppt & $\begin{array}{l}\text { Adjustment factor for computed solar radiation } \\
\text { for summer day with greater than ppt_rad_adj } \\
\text { inches precipitation }\end{array}$ & one & real & decimal fraction & 0.0 to 1.0 & 0.44 & required \\
\hline radj_wppt & $\begin{array}{l}\text { Adjustment factor for computed solar radiation } \\
\text { for winter day with greater than ppt_rad_adj } \\
\text { inches precipitation }\end{array}$ & one & real & decimal fraction & 0.0 to 1.0 & 0.5 & required \\
\hline radmax & $\begin{array}{l}\text { Maximum fraction of the potential solar radiation } \\
\text { that may reach the ground due to haze, dust, } \\
\text { smog, and so forth }\end{array}$ & one & real & decimal fraction & 0.1 to 1.0 & 0.8 & required \\
\hline radpl_aspect & $\begin{array}{l}\text { Aspect for each radiation plane; used if control } \\
\text { parameter }\end{array}$ & nradpl & real & degrees & 0.0 to 360.0 & 0.0 & $\begin{array}{l}\text { solrad_module }= \\
\text { ddsolrad_prms or } \\
\text { ccsolrad_prms }\end{array}$ \\
\hline
\end{tabular}


Table 1-3. Parameters listed by usage with the associated modules in which they are used for the Precipitation-Runoff Modeling System, version 4 (PRMS-IV).-Continued

[HRU, hydrologic response unit; GWR, groundwater reservoir; cfs, cubic feet per second; cms, cubic meters per second; ET, evapotranspiration; dday, degree-day, the amount a day's average temperature departed from 65 degrees Fahrenheit; >, greater than; dimensions defined in table 1-1; control parameters temp_module, precip_module, solrad_module, et_module, transp_module, srunoff_module, strmflow_module, soilzone_module, model_mode, dprst_flag, subbasin_flag, cascade_flag, cascadegw_flag, and mapOutON_OFF defined in table 1-2. Note: modules soltab_prms, temp_2sta_prms, ccsolrad_prms, ddsolrad prms, potet hamon_prms, smbal_prms, ssflow prms, and hru sum_prms are deprecated and only included for backwards compatibility for PRMS models built prior to PRMS-IV]

\begin{tabular}{|c|c|c|c|c|c|c|c|}
\hline $\begin{array}{l}\text { Parameter } \\
\text { name }\end{array}$ & Description & Dimension $^{1}$ & Type & Units & Range & Default & Required/condition \\
\hline radpl_lat & Latitude of each radiation plane & nradpl & real & degrees & -90.0 to 90.0 & 40.0 & $\begin{array}{l}\text { solrad_module }= \\
\text { ddsolrad_prms or } \\
\text { ccsolrad_prms }\end{array}$ \\
\hline radpl_slope & $\begin{array}{l}\text { Slope of each radiation plane, specified as change } \\
\text { in vertical length divided by change in horizon- } \\
\text { tal length }\end{array}$ & nradpl & real & decimal fraction & 0.0 to 10.0 & 0.0 & $\begin{array}{l}\text { solrad_module }= \\
\text { ddsolrad_prms or } \\
\text { ccsolrad_prms }\end{array}$ \\
\hline tmax_index & $\begin{array}{l}\text { Monthly (January to December) index tempera- } \\
\text { ture used to determine precipitation adjust- } \\
\text { ments to solar radiation }\end{array}$ & nmonths & real & temp_units & -10.0 to 110.0 & 50.0 & $\begin{array}{l}\text { solrad_module }= \\
\text { ddsolrad or } \\
\text { ddsolrad_prms }\end{array}$ \\
\hline \multicolumn{8}{|c|}{ Potential evapotranspiration distribution } \\
\hline epan_coef & $\begin{array}{l}\text { Monthly (January to December) evaporation pan } \\
\text { coefficient }\end{array}$ & nmonths & real & decimal fraction & 0.2 to 3.0 & 1.0 & $\begin{array}{l}\text { et_module }= \\
\text { potet_pan }\end{array}$ \\
\hline hamon_coef & $\begin{array}{l}\text { Monthly (January to December) air temperature } \\
\text { coefficient used in Hamon potential ET } \\
\text { computations }\end{array}$ & nmonths & real & none & 0.004 to 0.008 & 0.0055 & $\begin{array}{l}\text { et_module }= \\
\text { potet_hamon or } \\
\text { potet_hamon_prms }\end{array}$ \\
\hline hru_pansta & $\begin{array}{l}\text { Index of pan evaporation station used to compute } \\
\text { HRU potential ET }\end{array}$ & nhru & integer & none & 0 to nevap & 0 & $\begin{array}{l}\text { et_module }=\text { potet } \\
\text { pan and nevapl }>0\end{array}$ \\
\hline hs_krs & $\begin{array}{l}\text { Monthly (January to December) adjustment factor } \\
\text { used in Hargreaves-Samani potential ET com- } \\
\text { putations for each HRU }\end{array}$ & $\begin{array}{l}\text { nhru, } \\
\text { nmonths }\end{array}$ & real & decimal fraction & 0.005 to 1.0 & 0.0023 & $\begin{array}{l}\text { et_module } \\
\text { potet_hs }\end{array}$ \\
\hline jh_coef & $\begin{array}{l}\text { Monthly (January to December) air temperature } \\
\text { coefficient used in Jensen-Haise potential ET } \\
\text { computations }\end{array}$ & nmonths & real & $\begin{array}{l}\text { per degrees } \\
\text { Fahrenheit }\end{array}$ & 0.005 to 0.06 & 0.014 & $\begin{array}{l}\text { et_module } \\
\text { potet_jh }\end{array}$ \\
\hline jh_coef_hru & $\begin{array}{l}\text { Air temperature coefficient used in Jensen-Haise } \\
\text { potential ET computations for each HRU }\end{array}$ & nhru & real & $\begin{array}{l}\text { per degrees } \\
\text { Fahrenheit }\end{array}$ & 5.0 to 25.0 & 13.0 & $\begin{array}{l}\text { et_module } \\
\text { potet_jh }\end{array}$ \\
\hline pm_d_coef & $\begin{array}{l}\text { Monthly (January to December) Penman- } \\
\text { Monteith potential ET D wind speed coefficient } \\
\text { for each HRU }\end{array}$ & $\begin{array}{l}\text { nhru, } \\
\text { nmonths }\end{array}$ & real & seconds/ meter & 0.25 to 0.45 & 0.34 & $\begin{array}{l}\text { et_module }= \\
\text { potet_pm }\end{array}$ \\
\hline pm_n_coef & $\begin{array}{l}\text { Monthly (January to December) Penman- } \\
\text { Monteith potential ET N temperature coeffi- } \\
\text { cient for each HRU }\end{array}$ & $\begin{array}{l}\text { nhru, } \\
\text { nmonths }\end{array}$ & real & $\begin{array}{l}\text { degrees Celsius } \\
\text { per day }\end{array}$ & 850.0 to 950.0 & 900.0 & $\begin{array}{l}\text { et_module }= \\
\text { potet_pm }\end{array}$ \\
\hline pt_alpha & $\begin{array}{l}\text { Monthly (January to December) adjustment factor } \\
\text { used in Priestly-Taylor potential ET computa- } \\
\text { tions for each HRU }\end{array}$ & $\begin{array}{l}\text { nhru, } \\
\text { nmonths }\end{array}$ & real & decimal fraction & 1.0 to 2.0 & 1.26 & $\begin{array}{l}\text { et_module } \\
\text { potet_pt }\end{array}$ \\
\hline
\end{tabular}


Table 1-3. Parameters listed by usage with the associated modules in which they are used for the Precipitation-Runoff Modeling System, version 4 (PRMS-IV).—Continued

[HRU, hydrologic response unit; GWR, groundwater reservoir; cfs, cubic feet per second; cms, cubic meters per second; ET, evapotranspiration; dday, degree-day, the amount a day's average temperature departed from 65 degrees Fahrenheit; >, greater than; dimensions defined in table 1-1; control parameters temp_module, precip_module, solrad_module, et_module, transp_module, srunoff_module, strmflow module, soilzone module, model mode, dprst flag, subbasin flag, cascade flag, cascadegw flag, and mapOutON OFF defined in table 1-2. Note: modules soltab prms, temp 2sta prms, ccsolrad_prms, ddsolrad_prms, potet_hamon_prms, smbal_prms, ssflow_prms, and hru_sum_prms are deprecated and only included for backwards compatibility for PRMS models built prior to PRMS-IV]

\begin{tabular}{|c|c|c|c|c|c|c|c|}
\hline $\begin{array}{c}\text { Parameter } \\
\text { name }\end{array}$ & Description & Dimension' ${ }^{1}$ & Type & Units & Range & Default & Required/condition \\
\hline \multicolumn{8}{|c|}{ Evapotranspiration and sublimation } \\
\hline fall_frost & $\begin{array}{l}\text { The solar date (number of days after winter } \\
\text { solstice) of the first killing frost of the fall }\end{array}$ & nhru & integer & solar date & 1 to 366 & 264 & $\begin{array}{l}\text { transp_module }= \\
\text { transp_frost }\end{array}$ \\
\hline frost_temp & Temperature of killing frost & one & real & temp_units & -10.0 to 32.0 & 28.0 & $\begin{array}{l}\text { model_mode }= \\
\quad \text { FROST }\end{array}$ \\
\hline potet_sublim & $\begin{array}{l}\text { Fraction of potential ET that is sublimated from } \\
\text { snow in the canopy and snowpack }\end{array}$ & one & real & decimal fraction & 0.1 to 0.75 & 0.5 & required \\
\hline rad_trncf & $\begin{array}{l}\text { Transmission coefficient for short-wave radiation } \\
\text { through the winter vegetation canopy }\end{array}$ & nhru & real & decimal fraction & 0.0 to 1.0 & 0.5 & required \\
\hline soil_type & Soil type of each HRU (1=sand; $2=$ loam; $3=$ clay $)$ & nhru & integer & none & 1 to 3 & 2 & required \\
\hline spring_frost & $\begin{array}{l}\text { The solar date (number of days after winter sol- } \\
\text { stice) of the last killing frost of the springl }\end{array}$ & nhru & integer & solar date & 1 to 366 & 111 & $\begin{array}{l}\text { transp_module }= \\
\text { transp_frost }\end{array}$ \\
\hline transp_beg & $\begin{array}{l}\text { Month to begin summing maximum air tempera- } \\
\text { ture for each HRU; when sum is greater than or } \\
\text { equal to transp_tmax, transpiration begins }\end{array}$ & nhru & integer & month & 1 to 12 & 1 & $\begin{array}{l}\text { transp_module }= \\
\text { transp_tindex }\end{array}$ \\
\hline transp_end & $\begin{array}{l}\text { Month to stop transpiration computations; transpi- } \\
\text { ration is computed thru end of previous month }\end{array}$ & nhru & integer & month & 1 to 13 & 13 & $\begin{array}{l}\text { transp_module }= \\
\text { transp_tindex }\end{array}$ \\
\hline transp_tmax & $\begin{array}{l}\text { Temperature index to determine the specific date } \\
\text { of the start of the transpiration period;' the } \\
\text { maximum air temperature for each HRU is } \\
\text { summed starting with the first day of month } \\
\text { transp_beg; when the sum exceeds this index, } \\
\text { transpiration begins }\end{array}$ & nhru & real & temp_units & 0.0 to $1,000.0$ & 1.0 & $\begin{array}{l}\text { transp_module }= \\
\quad \text { transp_tindex }\end{array}$ \\
\hline \multicolumn{8}{|c|}{ Interception } \\
\hline cov_type & $\begin{array}{l}\text { Vegetation cover type for each HRU }(0=\text { bare soil; } \\
1=\text { grasses; } 2=\text { shrubs; } 3=\text { trees; } 4=\text { coniferous })\end{array}$ & nhru & integer & none & 0 to 4 & 3 & required \\
\hline covden_sum & $\begin{array}{l}\text { Summer vegetation cover density for the major } \\
\text { vegetation type in each HRU }\end{array}$ & nhru & real & decimal fraction & 0.0 to 1.0 & 0.5 & required \\
\hline covden_win & $\begin{array}{l}\text { Winter vegetation cover density for the major } \\
\text { vegetation type in each HRU }\end{array}$ & nhru & real & decimal fraction & 0.0 to 1.0 & 0.5 & required \\
\hline snow_intep & $\begin{array}{l}\text { Snow interception storage capacity for the major } \\
\text { vegetation type in each HRU }\end{array}$ & nhru & real & inches & 0.0 to 1.0 & 0.1 & required \\
\hline srain_intep & $\begin{array}{l}\text { Summer rain interception storage capacity for the } \\
\text { major vegetation type in each HRU }\end{array}$ & nhru & real & inches & 0.0 to 1.0 & 0.1 & required \\
\hline
\end{tabular}


Table 1-3. Parameters listed by usage with the associated modules in which they are used for the Precipitation-Runoff Modeling System, version 4 (PRMS-IV).-Continued

[HRU, hydrologic response unit; GWR, groundwater reservoir; cfs, cubic feet per second; cms, cubic meters per second; ET, evapotranspiration; dday, degree-day, the amount a day's average temperature departed from 65 degrees Fahrenheit; >, greater than; dimensions defined in table 1-1; control parameters temp_module, precip_module, solrad_module, et_module, transp_module, srunoff_module, strmflow_module, soilzone_module, model_mode, dprst_flag, subbasin_flag, cascade_flag, cascadegw_flag, and mapOutON_OFF defined in table 1-2. Note: modules soltab_prms, temp_2sta_prms, ccsolrad_prms, ddsolrad_prms, potet_hamon_prms, smbal_prms, ssflow_prms, and hru_sum_prms are deprecated and only included for backwards compatibility for PRMS models built prior to PRMS-IV]

\begin{tabular}{|c|c|c|c|c|c|c|c|}
\hline $\begin{array}{l}\text { Parameter } \\
\text { name }\end{array}$ & Description & Dimension ${ }^{1}$ & Type & Units & Range & Default & Required/condition \\
\hline wrain_intep & $\begin{array}{l}\text { Winter rain interception storage capacity for the } \\
\text { major vegetation type in each HRU }\end{array}$ & nhru & real & inches & 0.0 to 1.0 & 0.1 & required \\
\hline \multicolumn{8}{|c|}{ Snow computaions } \\
\hline albset_rna & $\begin{array}{l}\text { Fraction of rain in a mixed precipitation event } \\
\text { above which the snow albedo is not reset; ap- } \\
\text { plied during the snowpack accumulation stage }\end{array}$ & one & real & decimal fraction & 0.4 to 1.0 & 0.8 & required \\
\hline albset_rnm & $\begin{array}{l}\text { Fraction of rain in a mixed precipitation event } \\
\text { above which the snow albedo is not reset; ap- } \\
\text { plied during the snowpack melt stage }\end{array}$ & one & real & decimal fraction & 0.4 to 1.0 & 0.6 & required \\
\hline albset_sna & $\begin{array}{l}\text { Minimum snowfall, in water equivalent, needed } \\
\text { to reset snow albedo during the snowpack ac- } \\
\text { cumulation stage }\end{array}$ & one & real & inches & 0.01 to 1.0 & 0.05 & required \\
\hline albset_snm & $\begin{array}{l}\text { Minimum snowfall, in water equivalent, needed } \\
\text { to reset snow albedo during the snowpack melt } \\
\text { stage }\end{array}$ & one & real & inches & 0.1 to 1.0 & 0.2 & required \\
\hline cecn_coef & $\begin{array}{l}\text { Monthly (January to December) convection con- } \\
\text { densation energy coefficient }\end{array}$ & nmonths & real & $\begin{array}{l}\text { calories per degree } \\
\text { Celsius }>0\end{array}$ & 2.0 to 10.0 & 5.0 & required \\
\hline den_init & Initial density of new-fallen snow & one & real & $\begin{array}{l}\text { grams/cubic } \\
\text { centimeters }\end{array}$ & 0.01 to 0.5 & 0.1 & required \\
\hline den_max & Average maximum snowpack density & one & real & $\begin{array}{l}\text { grams/cubic } \\
\text { centimeters }\end{array}$ & 0.1 to 0.8 & 0.6 & required \\
\hline emis_noppt & $\begin{array}{l}\text { Average emissivity of air on days without precipi- } \\
\text { tation }\end{array}$ & one & real & decimal fraction & 0.757 to 1.0 & 0.757 & required \\
\hline freeh2o_cap & $\begin{array}{l}\text { Free-water holding capacity of snowpack ex- } \\
\text { pressed as a decimal fraction of the frozen wa- } \\
\text { ter content of the snowpack (variable } p k \_i c e \text { ) }\end{array}$ & one & real & decimal fraction & 0.01 to 0.2 & 0.05 & required \\
\hline hru_deplcrv & $\begin{array}{l}\text { Index number for the snowpack areal depletion } \\
\text { curve associated with each HRU }\end{array}$ & nhru & integer & none & 1 to ndepl & 1 & required \\
\hline melt_force & Julian date to force snowpack to spring snowmelt & one & integer & Julian day & 1 to 366 & 140 & required \\
\hline
\end{tabular}

melt_look stage; varie of time that permanent snowpack exists

Julian date to start looking for spring snowmelt stage; varies with region depending on length of time that permanent snowpack exists 
Table 1-3. Parameters listed by usage with the associated modules in which they are used for the Precipitation-Runoff Modeling System, version 4 (PRMS-IV).—Continued

[HRU, hydrologic response unit; GWR, groundwater reservoir; cfs, cubic feet per second; cms, cubic meters per second; ET, evapotranspiration; dday, degree-day, the amount a day's average temperature departed from 65 degrees Fahrenheit; >, greater than; dimensions defined in table 1-1; control parameters temp_module, precip_module, solrad_module, et_module, transp_module, srunoff_module, strmflow module, soilzone module, model_mode, dprst flag, subbasin flag, cascade flag, cascadegw flag, and mapOutON OFF defined in table 1-2. Note: modules soltab prms, temp 2sta prms, ccsolrad_prms, ddsolrad_prms, potet_hamon_prms, smbal_prms, ssflow_prms, and hru_sum_prms are deprecated and only included for backwards compatibility for PRMS models built prior to PRMS-IV]

\begin{tabular}{|c|c|c|c|c|c|c|c|}
\hline $\begin{array}{l}\text { Parameter } \\
\text { name }\end{array}$ & Description & Dimension ${ }^{1}$ & Type & Units & Range & Default & Required/condition \\
\hline settle_const & Snowpack settlement time constant & one & real & decimal fraction & 0.01 to 0.5 & 0.1 & required \\
\hline snarea_curve & $\begin{array}{l}\text { Snow area depletion curve values, } 11 \text { values for } \\
\text { each curve ( } 0.0 \text { to } 1.0 \text { in } 0.1 \text { increments })\end{array}$ & ndeplval & real & decimal fraction & 0.0 to 1.0 & 1.0 & required \\
\hline snarea_thresh & $\begin{array}{l}\text { Maximum threshold snowpack water equivalent } \\
\text { below which the snow-covered-area curve is } \\
\text { applied; varies with elevation }\end{array}$ & nhru & real & inches & 0.0 to 200.0 & 50.0 & required \\
\hline tstorm_mo & $\begin{array}{l}\text { Monthly indicator for prevalent storm type } \\
(0=\text { frontal storms; } 1=\text { convective storms })\end{array}$ & nmonths & integer & none & 0 or 1 & 0 & required \\
\hline \multicolumn{8}{|c|}{ Hortonian surface runoff, infiltration, and impervious storage } \\
\hline carea_max & $\begin{array}{l}\text { Maximum possible area contributing to surface } \\
\text { runoff expressed as a portion of the HRU area }\end{array}$ & nhru & real & decimal fraction & 0.0 to 1.0 & 0.6 & required \\
\hline carea_min & $\begin{array}{l}\text { Minimum possible area contributing to surface } \\
\text { runoff expressed as a portion of the area for } \\
\text { each HRU }\end{array}$ & nhru & real & decimal fraction & 0.0 to 1.0 & 0.2 & $\begin{array}{l}\text { srunoff_module }= \\
\text { srunoff_carea }\end{array}$ \\
\hline hru_percent_imperv ${ }^{2}$ & Fraction of each HRU area that is impervious & nhru & real & decimal fraction & 0.0 to 0.999 & 0.0 & required \\
\hline imperv_stor_max & $\begin{array}{l}\text { Maximum impervious area retention storage for } \\
\text { each HRU }\end{array}$ & nhru & real & inches & 0.0 to 0.1 & 0.05 & required \\
\hline smidx_coef & $\begin{array}{l}\text { Coefficient in non-linear contributing area algo- } \\
\text { rithm for each HRU }\end{array}$ & nhru & real & decimal fraction & 0.001 to 0.06 & 0.005 & $\begin{array}{l}\text { srunoff_module }= \\
\text { srunoff_smidx }\end{array}$ \\
\hline smidx_exp & $\begin{array}{l}\text { Exponent in non-linear contributing area algo- } \\
\text { rithm for each HRU }\end{array}$ & nhru & real & $1 /$ inch & 0.1 to 0.5 & 0.3 & $\begin{array}{l}\text { srunoff_module }= \\
\text { srunoff_smidx }\end{array}$ \\
\hline snowinfil_max & Maximum snow infiltration per day for each HRU & nhru & real & inches/day & 0.0 to 20.0 & 2.0 & required \\
\hline \multicolumn{8}{|c|}{ Surface depression storage } \\
\hline dprst_area & $\begin{array}{l}\text { Aggregate sum of surface depression areas of } \\
\text { each HRU }\end{array}$ & nhru & real & acres & 0.0 to $1.0 \mathrm{E} 9$ & 0.0 & dprst_flag $=1$ \\
\hline dprst_depth_avg & $\begin{array}{l}\text { Average depth of storage depressions at maxi- } \\
\text { mum storage capacity }\end{array}$ & nhru & real & inches & 0.0 to 500.0 & 132.0 & dprst_flag $=1$ \\
\hline dprst_et_coef & $\begin{array}{l}\text { Fraction of unsatisfied potential evapotranspira- } \\
\text { tion to apply to surface depression storage }\end{array}$ & nhru & real & decimal fraction & 0.0 to 1.0 & 1.0 & dprst_flag $=1$ \\
\hline dprst_flow_coef & $\begin{array}{l}\text { Coefficient in linear flow routing equation for } \\
\text { open surface depressions for each HRU }\end{array}$ & nhru & real & fraction/day & 0.0001 to 1.0 & 0.05 & dprst_flag $=1$ \\
\hline dprst_frac_init & Fraction of maximum surface depression storage & nhru & real & decimal fraction & 0.0 to 1.0 & 0.5 & dprst_flag $=1$ \\
\hline
\end{tabular}
that contains water at the start of a simulation 
Table 1-3. Parameters listed by usage with the associated modules in which they are used for the Precipitation-Runoff Modeling System, version 4 (PRMS-IV).-Continued

[HRU, hydrologic response unit; GWR, groundwater reservoir; cfs, cubic feet per second; cms, cubic meters per second; ET, evapotranspiration; dday, degree-day, the amount a day's average temperature departed from 65 degrees Fahrenheit; >, greater than; dimensions defined in table 1-1; control parameters temp_module, precip_module, solrad_module, et_module, transp_module, srunoff_module, strmflow_module, soilzone_module, model_mode, dprst_flag, subbasin_flag, cascade_flag, cascadegw_flag, and mapOutON_OFF defined in table 1-2. Note: modules soltab_prms, temp_2sta_prms, ccsolrad_prms, ddsolrad_prms, potet_hamon_prms, smbal_prms, ssflow_prms, and hru_sum_prms are deprecated and only included for backwards compatibility for PRMS models built prior to PRMS-IV]

\begin{tabular}{|c|c|c|c|c|c|c|c|}
\hline $\begin{array}{l}\text { Parameter } \\
\text { name }\end{array}$ & Description & Dimension ${ }^{1}$ & Type & Units & Range & Default & Required/condition \\
\hline dprst_frac_open & $\begin{array}{l}\text { Fraction of open surface depression storage area } \\
\text { within an HRU that can generate surface runoff } \\
\text { as a function of storage volume }\end{array}$ & nhru & double & decimal fraction & 0.0 to 1.0 & 1.0 & dprst_flag $=1$ \\
\hline dprst_seep_rate_clos & $\begin{array}{l}\text { Coefficient used in linear seepage flow equation } \\
\text { for closed surface depressions for each HRU }\end{array}$ & nhru & real & fraction/day & 0.0001 to 1.0 & 0.02 & dprst_flag $=1$ \\
\hline dprst_seep_rate_open & $\begin{array}{l}\text { Coefficient used in linear seepage flow equation } \\
\text { for open surface depressions for each HRU }\end{array}$ & nhru & real & fraction/day & 0.0001 to 1.0 & 0.02 & dprst_flag $=1$ \\
\hline op_flow_thres & $\begin{array}{l}\text { Fraction of open depression storage above which } \\
\text { surface runoff occurs for each time step; any } \\
\text { water above maximum open storage capacity } \\
\text { spills as surface runoff }\end{array}$ & nhru & real & decimal fraction & 0.75 to 1.0 & 1.0 & dprst_flag $=1$ \\
\hline sro_to_dprst & $\begin{array}{l}\text { Fraction of pervious surface runoff that flows into } \\
\text { surface depression storage; the remainder flows } \\
\text { to a stream network for each HRU }\end{array}$ & nhru & real & decimal fraction & 0.0 to 1.0 & 0.2 & dprst_flag $=1$ \\
\hline va_clos_exp & $\begin{array}{l}\text { Coefficient in the exponential equation relat- } \\
\text { ing maximum surface area to the fraction that } \\
\text { closed depressions are full to compute current } \\
\text { surface area for each HRU }\end{array}$ & nhru & real & none & 0.0001 to 10.0 & 1.0 & dprst_flag $=1$ \\
\hline va_open_exp & $\begin{array}{l}\text { Coefficient in the exponential equation relating } \\
\text { maximum surface area to the fraction that open } \\
\text { depressions are full to compute current surface } \\
\text { area for each HRU }\end{array}$ & nhru & real & none & 0.0001 to 10.0 & 1.0 & dprst_flag $=1$ \\
\hline \multicolumn{8}{|c|}{ Soil zone storage, interflow, gravity drainage, dunnian surface runoff } \\
\hline fastcoef_lin & $\begin{array}{l}\text { Linear coefficient in equation to route } \\
\text { preferential-flow storage down slope for each } \\
\text { HRU }\end{array}$ & nhru & real & fraction/day & 0.001 to 1.0 & 0.1 & required $^{8}$ \\
\hline fastcoef_sq & $\begin{array}{l}\text { Non-linear coefficient in equation to route } \\
\text { preferential-flow storage down slope for each } \\
\text { HRU }\end{array}$ & nhru & real & none & 0.001 to 1.0 & 0.8 & required $^{8}$ \\
\hline hru_ssres ${ }^{7}$ & $\begin{array}{l}\text { Index of subsurface reservoir receiving excess } \\
\text { water from capillary reservoir }\end{array}$ & nhru & integer & none & 1 to $\mathbf{n s s r}$ & 1 & $\begin{array}{l}\text { soilzone_module }= \\
\text { smbal_prms }\end{array}$ \\
\hline pref_flow_den & $\begin{array}{l}\text { Fraction of the soil zone in which preferential } \\
\text { flow occurs for each HRU; used if control }\end{array}$ & nhru & real & decimal fraction & 0.0 to 1.0 & 0.0 & required $^{8}$ \\
\hline
\end{tabular}
flow occurs for each HRU; used if control parameter 
Table 1-3. Parameters listed by usage with the associated modules in which they are used for the Precipitation-Runoff Modeling System, version 4 (PRMS-IV).—Continued

[HRU, hydrologic response unit; GWR, groundwater reservoir; cfs, cubic feet per second; cms, cubic meters per second; ET, evapotranspiration; dday, degree-day, the amount a day's average temperature departed from 65 degrees Fahrenheit; >, greater than; dimensions defined in table 1-1; control parameters temp_module, precip_module, solrad_module, et_module, transp_module, srunoff_module, strmflow module, soilzone module, model mode, dprst flag, subbasin flag, cascade flag, cascadegw flag, and mapOutON OFF defined in table 1-2. Note: modules soltab prms, temp 2sta prms, ccsolrad_prms, ddsolrad_prms, potet_hamon_prms, smbal_prms, ssflow_prms, and hru_sum_prms are deprecated and only included for backwards compatibility for PRMS models built prior to PRMS-IV]

\begin{tabular}{|c|c|c|c|c|c|c|c|}
\hline $\begin{array}{c}\text { Parameter } \\
\text { name }\end{array}$ & Description & Dimension $^{1}$ & Type & Units & Range & Default & Required/condition \\
\hline sat_threshold & $\begin{array}{l}\text { Water holding capacity of the gravity and prefer- } \\
\text { ential flow reservoirs; difference between field } \\
\text { capacity and total soil saturation for each HRU }\end{array}$ & nhru & real & inches & 1.0 to 999.0 & 999.0 & required $^{8}$ \\
\hline slowcoef_lin & $\begin{array}{l}\text { Linear coefficient in equation to route gravity- } \\
\text { reservoir storage down slope for each HRU }\end{array}$ & nhru & real & fraction/day & 0.001 to 0.5 & 0.015 & required $^{8}$ \\
\hline slowcoef_sq & $\begin{array}{l}\text { Non-linear coefficient in equation to route grav- } \\
\text { ity- reservoir storage down slope for each HRU }\end{array}$ & nhru & real & none & 0.001 to 1.0 & 0.1 & required $^{8}$ \\
\hline soil_moist_init & $\begin{array}{l}\text { Initial value of available water in capillary reser- } \\
\text { voir for each HRU }\end{array}$ & nhru & real & inches & 0.0 to 10.0 & 3.0 & required \\
\hline soil_moist_max & $\begin{array}{l}\text { Maximum available water holding capacity of } \\
\text { capillary reservoir from land surface to rooting } \\
\text { depth of the major vegetation type of each } \\
\text { HRU; affects Hortonian surface runoff, ET, } \\
\text { direct recharge, and flow to gravity reservoir }\end{array}$ & nhru & real & inches & 0.001 to 10.0 & 2.0 & required \\
\hline soil_rechr_init & $\begin{array}{l}\text { Initial storage for soil recharge zone (upper part } \\
\text { of capillary reservoir where losses occur as } \\
\text { both evaporation and transpiration) for each } \\
\text { HRU; must be less than or equal to soil_moist_ } \\
\text { init }\end{array}$ & nhru & real & inches & 0.0 to 10.0 & 1.0 & required \\
\hline soil_rechr_max & $\begin{array}{l}\text { Maximum storage for soil recharge zone (upper } \\
\text { portion of capillary reservoir where losses } \\
\text { occur as both evaporation and transpiration); } \\
\text { must be less than or equal to soil_moist_max; } \\
\text { affects Hortonian surface runoff and ET }\end{array}$ & nhru & real & inches & 0.001 to 5.0 & 1.5 & required \\
\hline soil2gw_max & $\begin{array}{l}\text { Maximum amount of the capillary reservoir } \\
\text { excess that is routed directly to the GWR for } \\
\text { each HRU }\end{array}$ & nhru & real & inches & 0.0 to 5.0 & 0.0 & required \\
\hline ssr2gw_exp & $\begin{array}{l}\text { Non-linear coefficient in equation used to route } \\
\text { water from the gravity reservoirs to the GWR } \\
\text { for each HRU }\end{array}$ & nhru & real & none & 0.0 to 3.0 & 1.0 & required \\
\hline ssr2gw_rate & Linear coefficient in equation used to route water & nhru & real & fraction/day & 0.05 to 0.8 & 0.1 & required \\
\hline
\end{tabular}


Table 1-3. Parameters listed by usage with the associated modules in which they are used for the Precipitation-Runoff Modeling System, version 4 (PRMS-IV).—Continued

[HRU, hydrologic response unit; GWR, groundwater reservoir; cfs, cubic feet per second; cms, cubic meters per second; ET, evapotranspiration; dday, degree-day, the amount a day's average temperature departed from 65 degrees Fahrenheit; >, greater than; dimensions defined in table 1-1; control parameters temp_module, precip_module, solrad_module, et_module, transp_module, srunoff_module, strmflow_module, soilzone_module, model_mode, dprst_flag, subbasin_flag, cascade_flag, cascadegw_flag, and mapOutON_OFF defined in table 1-2. Note: modules soltab_prms, temp_2sta_prms, ccsolrad_prms, ddsolrad_prms, potet_hamon_prms, smbal_prms, ssflow_prms, and hru_sum_prms are deprecated and only included for backwards compatibility for PRMS models built prior to PRMS-IV]

\begin{tabular}{|c|c|c|c|c|c|c|c|}
\hline $\begin{array}{l}\text { Parameter } \\
\text { name }\end{array}$ & Description & Dimension $^{1}$ & Type & Units & Range & Default & Required/condition \\
\hline ssrcoef_lin $^{8}$ & $\begin{array}{l}\text { Coefficient to route subsurface storage to stream- } \\
\text { flow using the following equation: ssres_flow } \\
=\text { ssrcoef_lin * ssres_stor }+ \text { ssrcoef_sq } * \\
\text { ssres_stor**2 }\end{array}$ & nssr & real & fraction/day & 0.0 to 1.0 & 0.1 & $\begin{array}{l}\text { soilzone_module }= \\
\text { smbal_prms }\end{array}$ \\
\hline ssrcoef_sq ${ }^{8}$ & $\begin{array}{l}\text { Coefficient to route subsurface storage to stream- } \\
\text { flow using the following equation: ssres_flow } \\
=\text { ssrcoef_lin } * \text { ssres_stor }+ \text { ssrcoef_sq } * \\
\text { ssres_stor**2 }\end{array}$ & nssr & real & none & 0.0 to 1.0 & 0.1 & $\begin{array}{l}\text { soilzone_module }= \\
\text { smbal_prms }\end{array}$ \\
\hline ssrmax_coef ${ }^{8}$ & $\begin{array}{l}\text { Coefficient in equation used to route water from } \\
\text { the subsurface reservoirs to the groundwater } \\
\text { reservoirs: ssr_to_gw }=\mathbf{s s r} \mathbf{2 g w} \text { grate * ((ssres_- } \\
\text { stor/ssrmax_coef)**ssr2gw_exp); recom- } \\
\text { mended value is } 1.0\end{array}$ & nssr & real & inches & 1.0 to 20.0 & 1.0 & $\begin{array}{l}\text { soilzone_module }= \\
\text { smbal_prms }\end{array}$ \\
\hline ssstor_init & $\begin{array}{l}\text { Initial storage of the gravity and preferential-flow } \\
\text { reservoirs for each HRU }\end{array}$ & nhru & real & inches & 0.0 to 20.0 & 0.0 & required \\
\hline \multicolumn{8}{|c|}{ Groundwater flow } \\
\hline gwflow_coef & $\begin{array}{l}\text { Linear coefficient in the equation to compute } \\
\text { groundwater discharge for each GWR }\end{array}$ & ngw & real & fraction/day & 0.001 to 0.5 & 0.015 & required \\
\hline gwsink_coef & $\begin{array}{l}\text { Linear coefficient in the equation to compute out- } \\
\text { flow to the groundwater sink for each GWR }\end{array}$ & ngw & real & fraction/day & 0.0 to 1.0 & 0.0 & required \\
\hline gwstor_init & $\begin{array}{l}\text { Storage in each GWR at the beginning of a } \\
\text { simulation }\end{array}$ & ngw & real & inches & 0.0 to 10.0 & 2.0 & required \\
\hline gwstor_min & $\begin{array}{l}\text { Minimum storage in each GWR to ensure storage } \\
\text { is greater than specified value to account for } \\
\text { inflow from deep aquifers or injection wells } \\
\text { with the water source outside the basin }\end{array}$ & ngw & real & inches & 0.0 to 1.0 & 0.0 & required \\
\hline hru_gwres ${ }^{7}$ & $\begin{array}{l}\text { Index of GWR receiving soil-zone drainage from } \\
\text { each associated HRU }\end{array}$ & nhru & integer & none & 1 to $\mathbf{n g w}$ & 1 & $\begin{array}{l}\text { soilzone_module }= \\
\text { smbal_prms }\end{array}$ \\
\hline ssr_gwres ${ }^{7}$ & $\begin{array}{l}\text { Index of the GWR that receives flow from each } \\
\text { associated subsurface or gravity reservoir }\end{array}$ & nssr & integer & none & 1 to $\mathbf{n g w}$ & 1 & $\begin{array}{c}\text { soilzone_module }= \\
\text { smbal_prms }\end{array}$ \\
\hline \multicolumn{8}{|c|}{ Streamflow and lake routing } \\
\hline hru_segment & $\begin{array}{l}\text { Segment index to which an HRU contributes } \\
\text { lateral flows (surface runoff, interflow, and } \\
\text { groundwater discharge) }\end{array}$ & nhru & integer & none & 0 to nsegment & 0 & $\begin{array}{l}\text { strmflow_mod- } \\
\text { ule = muskingum, } \\
\text { strmflow_in_out, or } \\
\text { strmflow_lake }\end{array}$ \\
\hline
\end{tabular}


Table 1-3. Parameters listed by usage with the associated modules in which they are used for the Precipitation-Runoff Modeling System, version 4 (PRMS-IV).—Continued

[HRU, hydrologic response unit; GWR, groundwater reservoir; cfs, cubic feet per second; cms, cubic meters per second; ET, evapotranspiration; dday, degree-day, the amount a day's average temperature departed from 65 degrees Fahrenheit; >, greater than; dimensions defined in table 1-1; control parameters temp_module, precip_module, solrad_module, et_module, transp_module, srunoff_module, strmflow module, soilzone module, model mode, dprst flag, subbasin flag, cascade flag, cascadegw flag, and mapOutON OFF defined in table 1-2. Note: modules soltab prms, temp 2sta prms, ccsolrad_prms, ddsolrad_prms, potet_hamon_prms, smbal_prms, ssflow_prms, and hru_sum_prms are deprecated and only included for backwards compatibility for PRMS models built prior to PRMS-IV]

\begin{tabular}{|c|c|c|c|c|c|c|c|}
\hline $\begin{array}{c}\text { Parameter } \\
\text { name }\end{array}$ & Description & Dimension $^{1}$ & Type & Units & Range & Default & Required/condition \\
\hline
\end{tabular}

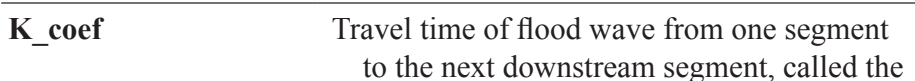

Muskingum storage coefficient; enter 1.0 for

reservoirs, diversions, and segment(s) flowing out of the basin

obsin_segment

Index of measured streamflow station that replaces inflow to a segment

nsegment integer

none

0 to nobs muskingum

tosegment

Index of downstream segment to which the segment streamflow flows; for segments that do

nsegment

integer

none

0 to nsegment

0

not flow to another segment enter 0

x_coef

The amount of attenuation of the flow wave, called the Muskingum routing weighting factor; enter 0.0 for reservoirs, diversions, and segment(s) flowing out of the basin

\begin{tabular}{|c|c|c|c|c|c|c|c|}
\hline-200 & $\begin{array}{l}\text { called the Muskingum routing weighting fac- } \\
\text { segment(s) flowing out of the basin }\end{array}$ & - & Tht & 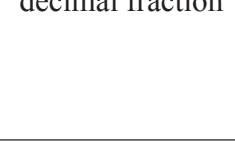 & 0.040 .0 & 0.0 & muskingum \\
\hline \multicolumn{8}{|c|}{ Lake routing } \\
\hline elev_outflow & $\begin{array}{l}\text { Elevation of the main outflow point in each lake } \\
\text { HRU using broad-crested weir routing }\end{array}$ & nlake & real & feet & -300.0 to $10,000.0$ & 0.0 & $\begin{array}{l}\text { strmflow_module }= \\
\text { strmflow_lake }\end{array}$ \\
\hline elevlake_init & $\begin{array}{l}\text { Initial lake surface elevation for lake HRUs using } \\
\text { broad-crested weir routing or gate opening } \\
\text { routing }\end{array}$ & nlake & real & feet & -300.0 to $10,000.0$ & 1.0 & $\begin{array}{l}\text { strmflow_module }= \\
\text { strmflow_lake }\end{array}$ \\
\hline gw_seep_coef & $\begin{array}{l}\text { Linear coefficient in equation to compute lakebed } \\
\text { seepage to the GWR and groundwater dis- } \\
\text { charge to lake HRUs using broad-crested weir } \\
\text { routing or gate opening routing }\end{array}$ & nlake & real & fraction/day & 0.001 to 0.05 & 0.015 & $\begin{array}{l}\text { strmflow_module }= \\
\text { strmflow_lake }\end{array}$ \\
\hline lake_coef & $\begin{array}{l}\text { Coefficient in equation to route lake to streamflow } \\
\text { for lake HRUs using linear routing }\end{array}$ & nlake & real & fraction/day & 0.0001 to 1.0 & 0.1 & $\begin{array}{l}\text { strmflow_module }= \\
\text { strmflow_lake }\end{array}$ \\
\hline lake_din1 & $\begin{array}{l}\text { Initial inflow to each lake HRU using Puls or } \\
\text { linear routing }\end{array}$ & nlake & real & $\mathrm{cfs}$ & 0.0 to $1.0 \mathrm{E} 7$ & 0.1 & $\begin{array}{l}\text { strmflow_module }= \\
\text { strmflow_lake }\end{array}$ \\
\hline lake_evap_adj & $\begin{array}{l}\text { Monthly (January to December) adjustment factor } \\
\text { for potential ET for each lake }\end{array}$ & nhru & real & decimal fraction & 0.5 to 1.0 & 1.0 & $\begin{array}{l}\text { strmflow_module }= \\
\text { strmflow_lake }\end{array}$ \\
\hline lake_hru & Index of HRU for each lake HRU & nlake & integer & none & 1 to nhru & 1 & $\begin{array}{l}\text { strmflow_module }= \\
\text { strmflow_lake }\end{array}$ \\
\hline
\end{tabular}

mflow_module muskingum, strmflow_in_out, or strmflow_lake

trmflow_module = muskingum, strmflow in out, or strmflow_lake 
Table 1-3. Parameters listed by usage with the associated modules in which they are used for the Precipitation-Runoff Modeling System, version 4 (PRMS-IV).-Continued

[HRU, hydrologic response unit; GWR, groundwater reservoir; cfs, cubic feet per second; cms, cubic meters per second; ET, evapotranspiration; dday, degree-day, the amount a day's average temperature departed from 65 degrees Fahrenheit; >, greater than; dimensions defined in table 1-1; control parameters temp_module, precip_module, solrad_module, et_module, transp_module, srunoff_module, strmflow_module, soilzone_module, model_mode, dprst_flag, subbasin_flag, cascade_flag, cascadegw_flag, and mapOutON_OFF defined in table 1-2. Note: modules soltab_prms, temp_2sta_prms, ccsolrad_prms, ddsolrad_prms, potet_hamon_prms, smbal_prms, ssflow_prms, and hru_sum_prms are deprecated and only included for backwards compatibility for PRMS models built prior to PRMS-IV]

\begin{tabular}{|c|c|c|c|c|c|c|c|}
\hline $\begin{array}{l}\text { Parameter } \\
\text { name }\end{array}$ & Description & Dimension $^{1}$ & Type & Units & Range & Default & Required/condition \\
\hline lake_hru_id & $\begin{array}{l}\text { Identification number of the lake associated with } \\
\text { an HRU; more than one HRU can be associated } \\
\text { with each lake }\end{array}$ & nhru & integer & none & 0 to nlake & 0 & $\begin{array}{l}\text { strmflow_module }= \\
\text { strmflow_lake }\end{array}$ \\
\hline lake_init & $\begin{array}{l}\text { Initial storage in each lake HRU using Puls or } \\
\text { linear routing }\end{array}$ & nlake & real & cfs-days & 0.0 to $1.0 \mathrm{E} 7$ & 0.0 & $\begin{array}{l}\text { strmflow_module }= \\
\text { strmflow_lake }\end{array}$ \\
\hline lake_out2 & $\begin{array}{l}\text { Switch to specify a second outflow point from } \\
\text { any lake HRUs using gate opening routing } \\
(0=\text { no; } 1=\text { yes })\end{array}$ & nlake & integer & none & 0 or 1 & 0 & $\begin{array}{l}\text { strmflow_module }= \\
\text { strmflow_lake }\end{array}$ \\
\hline lake_out2_a & $\begin{array}{l}\text { Coefficient } \mathrm{A} \text { in outflow equation for any lake } \\
\text { HRU using gate opening routing }\end{array}$ & nlake & real & cfs/feet & 0.0 to $10,000.0$ & 1.0 & $\begin{array}{l}\text { strmflow_module }= \\
\text { strmflow_lake }\end{array}$ \\
\hline lake_out2_b & $\begin{array}{l}\text { Coefficient B in outflow equation for any lake } \\
\text { HRU using gate opening routing }\end{array}$ & nlake & real & $\mathrm{cfs}$ & 0.0 to $10,000.0$ & 100.0 & $\begin{array}{l}\text { strmflow_module }= \\
\text { strmflow_lake }\end{array}$ \\
\hline lake_qro & Initial daily mean outflow from each lake HRU & nlake & real & $\mathrm{cfs}$ & 0.0 to $1.0 \mathrm{E} 7$ & 0.0 & $\begin{array}{l}\text { strmflow_module }= \\
\text { strmflow_lake }\end{array}$ \\
\hline lake_seep_elev & $\begin{array}{l}\text { Elevation over which lakebed seepage to the } \\
\text { GWR occurs for lake HRUs using broad-crest- } \\
\text { ed weir routing or gate opening routing }\end{array}$ & nlake & real & feet & -300.0 to $10,000.0$ & 1.0 & $\begin{array}{l}\text { strmflow_module }= \\
\text { strmflow_lake }\end{array}$ \\
\hline lake_type & $\begin{array}{l}\text { Type of lake routing method }(1=\text { Puls routing; } \\
2=\text { =linear routing; } 3=\text { flow through; } 4=\text { broad } \\
\text { crested weir; } 5=\text { gate opening; and } 6=\text { measured } \\
\text { flow })\end{array}$ & nlake & integer & none & 1 to 6 & 1 & $\begin{array}{l}\text { strmflow_module }= \\
\text { strmflow_lake }\end{array}$ \\
\hline lake_vol_init & $\begin{array}{l}\text { Initial lake volume for lake HRUs using broad- } \\
\text { crested weir or gate opening routing }\end{array}$ & nlake & real & acre-feet & 0.0 to $1.0 \mathrm{E} 7$ & 0.0 & $\begin{array}{l}\text { strmflow_module }= \\
\text { strmflow_lake }\end{array}$ \\
\hline nsos & $\begin{array}{l}\text { Number of storage/outflow values in table for } \\
\text { each lake HRU using Puls routing }\end{array}$ & $\begin{array}{l}\text { mxnsos, } \\
\text { nlake }\end{array}$ & integer & none & 1 to mxnsos & 0 & $\begin{array}{l}\text { strmflow_module }= \\
\text { strmflow_lake }\end{array}$ \\
\hline 02 & $\begin{array}{l}\text { Outflow values in outflow/storage tables for each } \\
\text { HRUs using for Puls routing }\end{array}$ & $\begin{array}{l}\text { mxnsos, } \\
\text { nlake }\end{array}$ & real & $\mathrm{cfs}$ & 0.0 to $1.0 \mathrm{E} 7$ & 0.0 & $\begin{array}{l}\text { strmflow_module }= \\
\text { strmflow_lake }\end{array}$ \\
\hline obsout_lake & $\begin{array}{l}\text { Index of measured streamflow station that speci- } \\
\text { fies outflow from each lake using measured } \\
\text { flow replacement }\end{array}$ & nlake & integer & none & 0 to nobs & 0 & $\begin{array}{l}\text { strmflow_module }= \\
\text { strmflow_lake }\end{array}$ \\
\hline rate_table & $\begin{array}{l}\text { Rating table with stage (rows) and gate opening } \\
\text { (cols) for rating table } 1 \text { for lake HRUs using }\end{array}$ & $\begin{array}{c}\text { nstage, } \\
\text { ngate }\end{array}$ & real & $\mathrm{cfs}$ & -100.0 to $1,000.0$ & 5.0 & $\begin{array}{l}\text { strmflow_module }= \\
\text { strmflow_lake }\end{array}$ \\
\hline
\end{tabular}


[HRU, hydrologic response unit; GWR, groundwater reservoir; cfs, cubic feet per second; cms, cubic meters per second; ET, evapotranspiration; dday, degree-day, the amount a day's average temperature departed from 65 degrees Fahrenheit; >, greater than; dimensions defined in table 1-1; control parameters temp_module, precip_module, solrad_module, et_module, transp_module, srunoff_module, strmflow module, soilzone module, model mode, dprst flag, subbasin flag, cascade flag, cascadegw flag, and mapOutON OFF defined in table 1-2. Note: modules soltab prms, temp 2sta prms, ccsolrad_prms, ddsolrad_prms, potet_hamon_prms, smbal_prms, ssflow_prms, and hru_sum_prms are deprecated and only included for backwards compatibility for PRMS models built prior to PRMS-IV]

\begin{tabular}{|c|c|c|c|c|c|c|c|}
\hline $\begin{array}{l}\text { Parameter } \\
\text { name }\end{array}$ & Description & Dimension $^{1}$ & Type & Units & Range & Default & Required/condition \\
\hline rate_table2 & $\begin{array}{l}\text { Rating table with stage (rows) and gate opening } \\
\text { (cols) for rating table } 2 \text { for lake HRUs using } \\
\text { gate opening routing and nratetbl }>1\end{array}$ & $\begin{array}{l}\text { nstage } 2, \\
\text { ngate2 }\end{array}$ & real & $\mathrm{cfs}$ & -100.0 to $1,000.0$ & 5.0 & $\begin{array}{l}\text { strmflow_module }= \\
\text { strmflow_lake }\end{array}$ \\
\hline rate_table 3 & $\begin{array}{l}\text { Rating table with stage (rows) and gate opening } \\
\text { (cols) for rating table } 3 \text { for lake HRUs using } \\
\text { gate opening routing and nratetbl }>2\end{array}$ & $\begin{array}{c}\text { nstage } 3, \\
\text { ngate3 }\end{array}$ & real & $\mathrm{cfs}$ & -100.0 to $1,000.0$ & 5.0 & $\begin{array}{l}\text { strmflow_module }= \\
\text { strmflow_lake }\end{array}$ \\
\hline rate_table4 & $\begin{array}{l}\text { Rating table with stage (rows) and gate opening } \\
\text { (cols) for rating table } 4 \text { for lake HRUs using } \\
\text { gate opening routing and nratetbl }>3\end{array}$ & $\begin{array}{c}\text { nstage4, } \\
\text { ngate4 }\end{array}$ & real & $\mathrm{cfs}$ & -100.0 to $1,000.0$ & 5.0 & $\begin{array}{l}\text { strmflow_module }= \\
\text { strmflow_lake }\end{array}$ \\
\hline ratetbl_lake & $\begin{array}{l}\text { Index of lake associated with each rating table for } \\
\text { lake HRUs using gate opening routing }\end{array}$ & nratetbl & integer & none & 1 to nlake & 1 & $\begin{array}{l}\text { strmflow_module }= \\
\text { strmflow_lake }\end{array}$ \\
\hline s2 & $\begin{array}{l}\text { Storage values in outflow/storage table for each } \\
\text { HRUs using for Puls routing }\end{array}$ & $\begin{array}{l}\text { mxnsos, } \\
\text { nlake }\end{array}$ & real & $\mathrm{cfs}$ & 0.0 to $1.0 \mathrm{E} 7$ & 0.0 & $\begin{array}{l}\text { strmflow_module }= \\
\text { strmflow_lake }\end{array}$ \\
\hline tbl_gate & $\begin{array}{l}\text { Gate openings for each column for rating table } 1 \\
\text { for lake HRUs using gate opening routing and } \\
\text { nratetbl }>0\end{array}$ & ngate & real & inches & 0.0 to 20.0 & 0.0 & $\begin{array}{l}\text { strmflow_module }= \\
\text { strmflow_lake }\end{array}$ \\
\hline tbl_gate2 & $\begin{array}{l}\text { Gate openings for each column for rating table } 2 \\
\text { for lake HRUs using gate opening routing and } \\
\text { nratetbl }>1\end{array}$ & ngate2 & real & inches & 0.0 to 20.0 & 0.0 & $\begin{array}{l}\text { strmflow_module }= \\
\text { strmflow_lake }\end{array}$ \\
\hline tbl_gate3 & $\begin{array}{l}\text { Gate openings for each column for rating table } 3 \\
\text { for lake HRUs using gate opening routing and } \\
\text { nratetbl }>2\end{array}$ & ngate3 & real & inches & 0.0 to 20.0 & 0.0 & $\begin{array}{l}\text { strmflow_module }= \\
\text { strmflow_lake }\end{array}$ \\
\hline tbl_gate4 & $\begin{array}{l}\text { Gate openings for each column for rating table } 4 \\
\text { for lake HRUs using gate opening routing and } \\
\text { nratetbl }>3\end{array}$ & ngate4 & real & inches & 0.0 to 20.0 & 0.0 & $\begin{array}{l}\text { strmflow_module }= \\
\text { strmflow_lake }\end{array}$ \\
\hline tbl_stage & $\begin{array}{l}\text { Stage values for each row for rating table } 1 \text { for } \\
\text { lake HRUs using gate opening routing and } \\
\text { nratetbl }>0\end{array}$ & nstage & real & feet & -100.0 to $1,000.0$ & 5.0 & $\begin{array}{l}\text { strmflow_module }= \\
\text { strmflow_lake }\end{array}$ \\
\hline tbl_stage2 & $\begin{array}{l}\text { Stage values for each row for rating table } 2 \text { for } \\
\text { lake HRUs using gate opening routing and } \\
\text { nratetbl }>1\end{array}$ & nstage2 & real & feet & -100.0 to $1,000.0$ & 5.0 & $\begin{array}{l}\text { strmflow_module }= \\
\text { strmflow_lake }\end{array}$ \\
\hline tbl_stage3 & $\begin{array}{l}\text { Stage values for each row for rating table } 3 \text { for } \\
\text { lake HRUs using gate opening routing and }\end{array}$ & nstage 3 & real & feet & -100.0 to $1,000.0$ & 5.0 & $\begin{array}{l}\text { strmflow_module }= \\
\text { strmflow_lake }\end{array}$ \\
\hline
\end{tabular}
nratetbl $>2$ 
Table 1-3. Parameters listed by usage with the associated modules in which they are used for the Precipitation-Runoff Modeling System, version 4 (PRMS-IV).-Continued

[HRU, hydrologic response unit; GWR, groundwater reservoir; cfs, cubic feet per second; cms, cubic meters per second; ET, evapotranspiration; dday, degree-day, the amount a day's average temperature departed from 65 degrees Fahrenheit; >, greater than; dimensions defined in table 1-1; control parameters temp_module, precip_module, solrad_module, et_module, transp_module, srunoff_module, strmflow_module, soilzone_module, model_mode, dprst_flag, subbasin_flag, cascade_flag, cascadegw_flag, and mapOutON_OFF defined in table 1-2. Note: modules soltab_prms, temp_2sta_prms, ccsolrad_prms, ddsolrad prms, potet hamon prms, smbal prms, ssflow prms, and hru sum prms are deprecated and only included for backwards compatibility for PRMS models built prior to PRMS-IV]

\begin{tabular}{|c|c|c|c|c|c|c|c|}
\hline $\begin{array}{l}\text { Parameter } \\
\text { name }\end{array}$ & Description & Dimension $^{1}$ & Type & Units & Range & Default & Required/condition \\
\hline tbl_stage4 & $\begin{array}{l}\text { Stage values for each row for rating table } 4 \text { for } \\
\text { lake HRUs using gate opening routing and } \\
\text { nratetbl }>3\end{array}$ & nstage4 & real & feet & -100.0 to $1,000.0$ & 5.0 & $\begin{array}{l}\text { strmflow_module }= \\
\text { strmflow_lake }\end{array}$ \\
\hline weir_coef & $\begin{array}{l}\text { Coefficient for lake HRUs using broad-crested } \\
\text { weir routing }\end{array}$ & nlake & real & none & 2.0 to 3.0 & 2.7 & $\begin{array}{l}\text { strmflow_module }= \\
\text { strmflow_lake }\end{array}$ \\
\hline weir_len & $\begin{array}{l}\text { Weir length for lake HRUs using broad-crested } \\
\text { weir routing }\end{array}$ & nlake & real & feet & 1.0 to $1,000.0$ & 5.0 & $\begin{array}{l}\text { strmflow_module }= \\
\text { strmflow_lake }\end{array}$ \\
\hline \multicolumn{8}{|c|}{ Output options } \\
\hline moyrsum & $\begin{array}{l}\text { Switch for HRU monthly and yearly summary } \\
\qquad(0=\text { off, } 1=\text { on })\end{array}$ & one & integer & none & 0 or 1 & 0 & $\begin{array}{l}\text { solrad_module }= \\
\text { ddsolrad_prms or } \\
\text { ccsolrad_prms }\end{array}$ \\
\hline pmo & Month to print HRU summary & one & integer & none & 0 to 12 & 0 & $\begin{array}{l}\text { solrad_module }= \\
\text { ddsolrad_prms or } \\
\text { ccsolrad_prms }\end{array}$ \\
\hline print_freq & $\begin{array}{l}\text { Flag to select the output frequency; for combina- } \\
\text { tions, add index numbers, for example, daily } \\
\text { plus yearly }=10 \text {; yearly plus total }=3(0=\text { none; } \\
1=\text { run totals; } 2=\text { yearly; } 4=\text { monthly; } 8=\text { daily; or } \\
\text { additive combinations })\end{array}$ & one & integer & none & 0 to 15 & 3 & required \\
\hline print_type & $\begin{array}{l}\text { Flag to select the type of results written to the } \\
\text { output file }(0=\text { measured and simulated flow } \\
\text { only; } 1=\text { water balance table; } 2=\text { detailed output })\end{array}$ & one & integer & none & 0 to 2 & 1 & required \\
\hline \multicolumn{8}{|c|}{ Subbasin parameters } \\
\hline hru_subbasin & Index of subbasin assigned to each HRU & nhru & integer & none & 0 to user defined & 0 & subbasin_flag = 1 \\
\hline subbasin_down & $\begin{array}{l}\text { Index number for the downstream subbasin } \\
\text { whose inflow is outflow from this subbasin }\end{array}$ & nsub & integer & none & 0 to nsub & 0 & subbasin_flag $=1$ \\
\hline \multicolumn{8}{|c|}{ Mapped results parameters } \\
\hline gvr_cell_id ${ }^{9}$ & $\begin{array}{l}\text { Index of the grid cell associated with each gravity } \\
\text { reservoir }\end{array}$ & nhrucell & integer & none & 1 to ngwcell & 1 & $\underset{=1}{\text { mapOutON_OFF }}$ \\
\hline gvr_cell_pct ${ }^{9}$ & $\begin{array}{l}\text { Proportion of the grid cell area associated with } \\
\text { each gravity reservoir }\end{array}$ & nhrucell & real & decimal fraction & 0.0 to 1.0 & 1.0 & $\begin{array}{c}\text { mapOutON_OFF } \\
=1\end{array}$ \\
\hline gvr_hru_id ${ }^{9}$ & $\begin{array}{l}\text { Index of the HRU associated with each gravity } \\
\text { reservoir }\end{array}$ & nhrucell & integer & none & 1 to nhrucell & 1 & $\underset{=1}{\operatorname{mapOutON} \text { _OFF }}$ \\
\hline
\end{tabular}


Table 1-3. Parameters listed by usage with the associated modules in which they are used for the Precipitation-Runoff Modeling System, version 4 (PRMS-IV).—Continued

[HRU, hydrologic response unit; GWR, groundwater reservoir; cfs, cubic feet per second; cms, cubic meters per second; ET, evapotranspiration; dday, degree-day, the amount a day's average temperature departed from 65 degrees Fahrenheit; >, greater than; dimensions defined in table 1-1; control parameters temp_module, precip_module, solrad_module, et_module, transp_module, srunoff_module, strmflow module, soilzone module, model mode, dprst flag, subbasin_flag, cascade flag, cascadegw flag, and mapOutON_OFF defined in table 1-2. Note: modules soltab prms, temp 2sta prms, ccsolrad_prms, ddsolrad_prms, potet_hamon_prms, smbal_prms, ssflow_prms, and hru_sum_prms are deprecated and only included for backwards compatibility for PRMS models built prior to PRMS-IV]

\begin{tabular}{|c|c|c|c|c|c|c|c|}
\hline $\begin{array}{l}\text { Parameter } \\
\text { name }\end{array}$ & Description & Dimension' ${ }^{1}$ & Type & Units & Range & Default & Required/condition \\
\hline mapvars_freq & $\begin{array}{l}\text { Flag to specify the output frequency }(0=\text { none; } \\
1=\text { monthly; } 2=\text { yearly; } 3=\text { total; } 4=\text { monthly and } \\
\text { yearly; } 5=\text { monthly, yearly, and total; } 6=\text { weekly; } \\
7=\text { daily })\end{array}$ & one & integer & none & 0 to 7 & 0 & $\begin{array}{l}\text { mapOutON_OFF } \\
=1\end{array}$ \\
\hline mapvars_units & $\begin{array}{l}\text { Flag to specify conversion of the units of mapped } \\
\text { results ( } 0=\text { units of the variable; } 1=\text { inches to } \\
\text { feet; } 2=\text { inches to centimeters; } 3=\text { inches to } \\
\text { meters; as states or fluxes) }\end{array}$ & one & integer & none & 0 to 3 & 0 & $\begin{array}{c}\text { mapOutON_OFF } \\
=1\end{array}$ \\
\hline ncol & $\begin{array}{l}\text { Number of columns for each row of the mapped } \\
\text { results }\end{array}$ & one & integer & none & 1 to user defined & 1 & $\underset{=1}{\text { mapOutON_OFF }}$ \\
\hline prms_warmup & $\begin{array}{l}\text { Number of years to simulate before writing } \\
\text { mapped results }\end{array}$ & one & integer & years & 0 to user defined & 1 & $\underset{=1}{\text { mapOutON_OFF }}$ \\
\hline \multicolumn{8}{|c|}{ Parameters for cascading-flow simulation } \\
\hline cascade_flg & $\begin{array}{l}\text { Flag to indicate cascade type }(0=\text { allow many to } \\
\text { many; } 1=\text { force one to one })\end{array}$ & one & integer & none & 0 or 1 & 0 & $\begin{array}{c}\text { cascade_flag }=1 \\
\text { and ncascade }>0 \\
\text { and/or cascadegw_ } \\
\text { flag }=1 \text { ncascdgw } \\
>0\end{array}$ \\
\hline cascade_tol & $\begin{array}{l}\text { Cascade area below which a cascade link is } \\
\text { ignored }\end{array}$ & one & real & acres & $\begin{array}{l}0.0 \text { to } 0.75 \% \text { of } \\
\text { hru_area }\end{array}$ & 5.0 & $\begin{array}{c}\text { cascade_flag }=1 \\
\text { and ncascade }>0 \\
\text { and/or cascadegw_ } \\
\text { flag }=1 \text { ncascdgw } \\
>0\end{array}$ \\
\hline circle_switch & Switch to check for circles $(0=$ no check; $1=$ check $)$ & one & integer & none & 0 or 1 & 1 & $\begin{array}{c}\text { cascade_flag }=1 \\
\text { and ncascade }>0 \\
\text { and } / \text { or cascadegw_ } \\
\text { flag }=1 \text { ncascdgw } \\
>0\end{array}$ \\
\hline gw_down_id ${ }^{3}$ & $\begin{array}{l}\text { Index number of the downslope GWR to which } \\
\text { the upslope GWR contributes flow; }-1 \text { specifies } \\
\text { that cascading flow for cascade link leaves the } \\
\text { model domain as farfield flow }\end{array}$ & ncascdgw & integer & none & -1 to $\mathbf{n g w}$ & 1 & $\begin{array}{l}\text { cascadegw_flag }=1 \\
\text { and ncascdgw }>0\end{array}$ \\
\hline gw_pet_up & $\begin{array}{l}\text { Fraction of GWR area used to compute flow } \\
\text { contributed to a down slope GWR or stream }\end{array}$ & ncascdgw & real & decimal fraction & 0.0 to 1.0 & 1.0 & $\begin{array}{c}\text { cascadegw_flag }=1 \\
\text { and ncascdgw }>0\end{array}$ \\
\hline
\end{tabular}


Table 1-3. Parameters listed by usage with the associated modules in which they are used for the Precipitation-Runoff Modeling System, version 4 (PRMS-IV).—Continued

[HRU, hydrologic response unit; GWR, groundwater reservoir; cfs, cubic feet per second; cms, cubic meters per second; ET, evapotranspiration; dday, degree-day, the amount a day's average temperature departed from 65 degrees Fahrenheit; >, greater than; dimensions defined in table 1-1; control parameters temp_module, precip_module, solrad_module, et_module, transp_module, srunoff_module, strmflow_module, soilzone_module, model_mode, dprst_flag, subbasin_flag, cascade_flag, cascadegw_flag, and mapOutON_OFF defined in table 1-2. Note: modules soltab_prms, temp_2sta_prms, ccsolrad_prms, ddsolrad_prms, potet_hamon_prms, smbal_prms, ssflow_prms, and hru_sum_prms are deprecated and only included for backwards compatibility for PRMS models built prior to PRMS-IV]

\begin{tabular}{|c|c|c|c|c|c|c|c|}
\hline $\begin{array}{l}\text { Parameter } \\
\text { name }\end{array}$ & Description & Dimension $^{1}$ & Type & Units & Range & Default & Required/condition \\
\hline gw_strmseg_down_id & $\begin{array}{l}\text { Index number of the stream segment that cascade } \\
\text { area contributes flow }\end{array}$ & ncascdgw & integer & none & 0 to nsegment & 0 & $\begin{array}{l}\text { cascadegw_flag }=1 \\
\text { and } \text { ncascdgw }>0\end{array}$ \\
\hline gw_up_id & Index of GWR containing cascade area & ncascdgw & integer & none & 1 to $\mathbf{n g w}$ & 1 & $\begin{array}{l}\text { cascadegw_flag }=1 \\
\text { and ncascdgw }>0\end{array}$ \\
\hline hru_down_id ${ }^{4}$ & $\begin{array}{l}\text { Index number of the downslope HRU to which } \\
\text { the upslope HRU contributes flow; - } 1 \text { specifies } \\
\text { that cascading flow for cascade link leaves the } \\
\text { model domain as farfield flow }\end{array}$ & ncascade & integer & none & -1 to $\mathbf{n h r u}$ & 1 & $\begin{aligned} \text { cascade_flag } & =1 \\
\text { and ncascade } & >0\end{aligned}$ \\
\hline hru_pet_up & $\begin{array}{l}\text { Fraction of HRU area used to compute flow } \\
\text { contributed to a down slope HRU or stream } \\
\text { segment for cascade area }\end{array}$ & ncascade & real & decimal fraction & 0.0 to 1.0 & 1.0 & $\begin{array}{l}\text { cascade_flag }=1 \\
\text { and ncascade }>0\end{array}$ \\
\hline hru_strmseg_down_id & $\begin{array}{l}\text { Index number of the stream segment that cascade } \\
\text { area contributes flow }\end{array}$ & ncascade & integer & none & 0 to nsegment & 0 & $\begin{aligned} \text { cascade_flag } & =1 \\
\text { and ncascade } & >0\end{aligned}$ \\
\hline hru_up_id & Index of HRU containing cascade area & ncascade & integer & none & 0 to nhru & 1 & $\begin{array}{l}\text { cascade_flag }=1 \\
\text { and ncascade }>0\end{array}$ \\
\hline
\end{tabular}

${ }^{1}$ Dimensions defined in table 1-1.

${ }^{2}$ Parameter is used to compute variable $h r u \_f r a c \_i m p e r v$, which is hru_percent_imperv adjusted for the requirement that the sum of values for parameter dprst_area and hru_percent_imperv are $<0.999 \mathrm{x}$ hru_area for each HRU.

${ }^{3}$ If the value of $\mathbf{g w}$ _strmseg_down_id $>0$ for cascade link, this value is ignored. If specified as -1 , any down-slope flow leaves the basin and is added to any other farfield flow.

${ }^{4}$ If the value of hru_strmseg_down_id $>0$ for cascade link, this value is ignored. If specified as -1 , any down-slope flow leaves the basin and is added to any other farfield flow.

${ }^{5}$ Parameter can be modified if the code determines an HRU is a swale, based on values of the cascade parameters.

${ }^{6}$ Parameter required unless radiation planes are used; when control parameter solrad_module=ddsolrad_prms or ccsolrad_prms.

${ }^{7}$ Parameter required if dimensions nhru, nssr, and $\mathbf{n g w}$ are not equal (deprecated).

${ }^{8}$ Parameter required unless the unless control parameter soilzone_module=smbal_prms (deprecated) module.

${ }^{9}$ Parameter name is based on parameter of same name specified for the Groundwater and Surface-Water Flow (GSFLOW) model (Markstrom and others, 2008). Only required if the HRU map is different than the target map, that is, dimension nhru not equal to ngwcell.

${ }^{10}$ Parameter is compared to the computed variable basin_area_inv that is set to 1.0 divided by the total active model domain area, which is the sum of values for parameter hru_area, for HRUs with parameter hru_type $>0$ and is not used in any computations. 
Variables are states and fluxes that may vary each time step during the simulation. PRMS-IV input time-series variables (table 1-4), such as measured maximum air temperature (tmax) for each air temperature measurement station, are specified in the Data File. Internal variables, such as the soil-infiltration rate (infil) for each HRU, are calculated by the modules and are available for output to either the Statistics Variable (statvar) File or the Animation (animation) File. All variables are defined as arrays. Scalar variables have an array size of one and are specified by using the dimension one. Table 5 describes the PRMSIV variables and identifies modules they are used for input and output. Equation symbols used in this appendix that correspond directly to PRMS-IV input parameters and input and output variables are defined in tables 1-3 and 1-5.

Table 1-4. Time-series input variables that may be included in the Data File for the Precipitation-Runoff Modeling System, version 4 (PRMS-IV).

[cfs, cubic feet per second; cms, cubic meters per second; runoff_units, $0=$ cfs; $1=\mathrm{cms}$; precip_units, $0=$ inches; $1=$ millimeters; temp_units, $0=$ degrees Fahrenheit; $1=$ degrees Celsius; >=, greater than or equal to]

\begin{tabular}{|c|c|c|c|c|}
\hline Variable & Definition & Units & Valid range & Dimension ${ }^{1}$ \\
\hline gate_ht & Height of the gate opening at each dam with a gate & inches & $>=0.0$ & nratetbl \\
\hline humidity & Relative humidity at each measurement station & decimal fraction & 0.0 to 1.0 & nhumid \\
\hline pan_evap & Pan evaporation at each measurement station & inches & $>=0.0$ & nevap \\
\hline precip & Precipitation at each measurement station & precip_units & $>=0.0$ & nrain \\
\hline runoff & Streamflow at each measurement station & runoff_units & $>=0.0$ & nobs \\
\hline snowdepth & Snow depth at each measurement station & inches & $>=0.0$ & nsnow \\
\hline solrad & Solar radiation at each measurement station & Langleys & $>=0.0$ & nsol \\
\hline $\operatorname{tmax}$ & Maximum air temperature at each measurement station & temp_units & -99.0 to 150.0 & ntemp \\
\hline
\end{tabular}

${ }^{1}$ Dimensions defined in table 1-1. 
Table 1-5. Input and output variables for the Precipitation-Runoff Modeling System, version 4 (PRMS-IV).

[HRU, hydrologic response unit; GWR, groundwater reservoir; $C B H$, climate-by-HRU; ET, evapotranspiration; cfs: cubic feet per second; cms: cubic meters per second; >, greater than; runoff_units, $0=c f s$; $1=$ cms; precip_units, $0=$ inches; $1=$ =millimeters; temp_units, $0=$ degrees Fahrenheit; $1=$ degrees Celsius; control parameters temp_module, precip_module, et_module, strmflow_module, model_mode, dprst_ flag, subbasin_flag, cascade_flag, and cascadegw_flag defined in table 1-2]

\begin{tabular}{|c|c|c|c|c|c|}
\hline Variable name & Description & Dimension ${ }^{1}$ & Units & Data type & Availabilty/condition \\
\hline \multicolumn{6}{|c|}{ Climate distribution } \\
\hline basin_lakeprecip & Basin area-weighted average precipitation on lake HRUs & one & inches & double & nlake $>0$ \\
\hline basin_lapse_max & Basin area-weighted average maximum air temperature lapse rate per 1,000 feet & one & $\begin{array}{c}\text { temp_units/ } \\
\text { feet }\end{array}$ & real & $\begin{array}{c}\text { temp_module }= \\
\text { temp_dist } 2\end{array}$ \\
\hline basin_lapse_min & Basin area-weighted average minimum air temperature lapse rate per 1,000 feet & one & $\begin{array}{c}\text { temp_units/ } \\
\text { feet }\end{array}$ & real & $\begin{array}{c}\text { temp_module }= \\
\text { temp_dist } 2\end{array}$ \\
\hline basin_max_temp_mo & Monthly area-weighted average maximum air temperature & one & temp_units & double & always \\
\hline basin_min_temp_mo & Monthly area-weighted average minimum air temperature & one & temp_units & double & always \\
\hline basin_net_ppt & Basin area-weighted average throughfall & one & inches & double & always \\
\hline basin_net_ppt_mo & Monthly area-weighted average net precipitation & one & inches & double & always \\
\hline basin_obs_ppt & Basin area-weighted measured average precipitation & one & inches & double & always \\
\hline basin_ppt & Basin area-weighted average precipitation & one & inches & double & always \\
\hline basin_ppt_mo & Monthly area-weighted average precipitation & one & inches & double & always \\
\hline basin_rain & Basin area-weighted average rainfall & one & inches & double & always \\
\hline basin_snow & Basin area-weighted average snowfall & one & inches & double & always \\
\hline basin_temp & Basin area-weighted average air temperature & one & temp_units & double & always \\
\hline basin_tmax & Basin area-weighted maximum air temperature & one & temp_units & double & always \\
\hline basin_tmin & Basin area-weighted minimum air temperature & one & temp_units & double & always \\
\hline hru_ppt & Precipitation distributed to each HRU & nhru & inches & real & always \\
\hline hru_rain & Rain distributed to each HRU & nhru & inches & real & always \\
\hline hru_snow & Snow distributed to each HRU & nhru & inches & real & always \\
\hline humidity & Relative humidity at each measurement station & nhumid & decimal fraction & real & nhumid $>0$ \\
\hline humidity_hru & Relative humidity for each HRU & nhru & decimal fraction & real & $\begin{array}{l}\text { et_module }= \\
\text { potet_pm }\end{array}$ \\
\hline is_rain_day & Flag to indicate if it is raining anywhere in the basin & one & none & integer & $\begin{array}{l}\text { precip_module }= \\
\text { ide_dist or xyz_dist }\end{array}$ \\
\hline newsnow $^{2}$ & Flag to indicate if new snow fell on each HRU $(0=$ no; $1=$ yes $)$ & nhru & none & integer & always \\
\hline pptmix ${ }^{2}$ & $\begin{array}{l}\text { Flag to indicate if precipitation is a mixture of rain and snow for each HRU } \\
(0=\text { no; } 1=\text { yes })\end{array}$ & nhru & none & integer & always \\
\hline precip & Precipitation at each measurement station & nrain & precip_units & real & nrain $>0$ \\
\hline prmx & Fraction of rain in a mixed precipitation event for each HRU & nhru & decimal fraction & real & always \\
\hline
\end{tabular}


Table 1-5. Input and output variables for the Precipitation-Runoff Modeling System, version 4 (PRMS-IV).-Continued

[HRU, hydrologic response unit; GWR, groundwater reservoir; $C B H$, climate-by-HRU; ET, evapotranspiration; cfs: cubic feet per second; cms: cubic meters per second; $>$, greater than; runoff_units, $0=c f s$; $1=\mathrm{cms}$; precip_units, $0=$ inches; $1=$ millimeters; temp_units, $0=$ degrees Fahrenheit; $1=$ degrees Celsius; control parameters temp_module, precip_module, et_module, strmflow_module, model_mode, dprst_ flag, subbasin_flag, cascade_flag, and cascadegw_flag defined in table 1-2]

\begin{tabular}{|c|c|c|c|c|c|}
\hline Variable name & Description & Dimension $^{1}$ & Units & Data type & Availabilty/condition \\
\hline rain_day & Flag to set the form of any precipitation to rain $(0=$ determine form; $1=$ rain $)$ & one & none & integer & $\begin{array}{l}\text { precip_module } \\
\quad \text { xyz_dist }\end{array}$ \\
\hline subinc_precip & Area-weighted average precipitation from associated HRUs to each subbasin & nsub & inches & double & subbasin_flag $=1$ \\
\hline subinc_tavgc & Area-weighted average air temperature for associated HRUs to each subbasin & nsub & degrees Celsius & double & subbasin_flag $=1$ \\
\hline subinc_tmaxc & $\begin{array}{l}\text { Area-weighted average maximum air temperature for associated HRUs to each } \\
\text { subbasin }\end{array}$ & nsub & degrees Celsius & double & subbasin_flag $=1$ \\
\hline subinc_tminc & $\begin{array}{l}\text { Area-weighted average minimum air temperature for associated HRUs to each } \\
\text { subbasin }\end{array}$ & nsub & degrees Celsius & double & subbasin_flag $=1$ \\
\hline $\operatorname{tavgc}$ & Average air temperature distributed to each HRU & nhru & degrees Celsius & real & always \\
\hline $\operatorname{tavgf}$ & Average air temperature distributed to each HRU & nhru & $\begin{array}{l}\text { degrees Fahr- } \\
\text { enheit }\end{array}$ & real & always \\
\hline $\operatorname{tmax}$ & Maximum air temperature at each measurement station & ntemp & temp_units & real & ntemp $>0$ \\
\hline tmax_rain_sta & Maximum air temperature distributed to the precipitation stations & nrain & $\begin{array}{l}\text { degrees Fahr- } \\
\text { enheit }\end{array}$ & real & $\begin{array}{l}\text { precip_module }= \\
\text { ide_dist or xyz_dist }\end{array}$ \\
\hline $\operatorname{tmaxc}$ & Maximum air temperature distributed to each HRU & nhru & degrees Celsius & real & always \\
\hline $\operatorname{tmaxf}$ & Maximum air temperature distributed to each HRU & nhru & $\begin{array}{l}\text { degrees } \\
\text { Fahrenheit }\end{array}$ & real & always \\
\hline $\operatorname{tmin}$ & Minimum air temperature at each measurement station & ntemp & temp_units & real & ntemp $>0$ \\
\hline tmin_hru & Minimum air temperature distributed to each HRU & nhru & temp_units & real & always \\
\hline tmin_rain_sta & Minimum air temperature distributed to the precipitation measurement stations & nrain & $\begin{array}{l}\text { degrees } \\
\text { Fahrenheit }\end{array}$ & real & $\begin{array}{l}\text { precip_module }= \\
\text { ide_dist or xyz_dist }\end{array}$ \\
\hline $\operatorname{tminc}$ & Minimum air temperature distributed to each HRU & nhru & degrees Celsius & real & always \\
\hline $\operatorname{tminf}$ & Minimum air temperature distributed to each HRU & nhru & $\begin{array}{l}\text { degrees } \\
\text { Fahrenheit }\end{array}$ & real & always \\
\hline wind_speed & Wind speed at each measurement station & nwind & miles per hour & real & nwind $>0$ \\
\hline wind_speed_hru & Wind speed for each HRU & nhru & miles per hour & real & $\begin{array}{l}\text { et_module }=\text { po- } \\
\text { tet_pm }\end{array}$ \\
\hline \multicolumn{6}{|c|}{ Solar radiation distribution } \\
\hline basin_clear_sky & Basin area-weighted average clear sky proportion & one & decimal fraction & double & $\begin{array}{l}\text { solrad_module }= \\
\text { ccsolrad }\end{array}$ \\
\hline basin_horad & Potential shortwave radiation for the basin centroid & one & Langleys & double & always \\
\hline basin_orad & Basin area-weighted average shortwave radiation on a horizontal surface & one & Langleys & double & $\begin{array}{l}\text { solrad_module }= \\
\text { ccsolrad }\end{array}$ \\
\hline
\end{tabular}


Table 1-5. Input and output variables for the Precipitation-Runoff Modeling System, version 4 (PRMS-IV).-Continued

[HRU, hydrologic response unit; GWR, groundwater reservoir; CBH, climate-by-HRU; ET, evapotranspiration; cfs: cubic feet per second; cms: cubic meters per second; >, greater than; runoff_units, $0=$ cfs; $1=$ cms; precip_units, $0=$ inches; $1=$ =millimeters; temp_units, $0=$ degrees Fahrenheit; $1=$ degrees Celsius; control parameters temp_module, precip_module, et_module, strmflow_module, model_mode, dprst_ flag, subbasin_flag, cascade_flag, and cascadegw_flag defined in table 1-2]

\begin{tabular}{|c|c|c|c|c|c|}
\hline Variable name & Description & Dimension ${ }^{1}$ & Units & Data type & Availabilty/condition \\
\hline basin_potsw & Basin area-weighted average potential shortwave radiation & one & Langleys & double & always \\
\hline clear_sky & Clear sky proportion for each HRU & nhru & decimal fraction & double & $\begin{array}{l}\text { solrad_module }= \\
\text { ccsolrad }\end{array}$ \\
\hline orad & Measured or computed solar radiation on a horizontal surface & one & Langleys & real & always \\
\hline orad_hru & Solar radiation on a horizontal surface for each HRU & nhru & Langleys & real & $\begin{array}{l}\text { solrad_module }= \\
\text { ccsolrad }\end{array}$ \\
\hline seginc_swrad & $\begin{array}{l}\text { Area-weighted average solar radiation for each segment from HRUs contributing } \\
\text { flow to the segment }\end{array}$ & nsegment & Langleys & real & nsegment $>0$ \\
\hline solrad & Solar radiation at each measurement station & nsol & Langleys & real & nsol $>0$ \\
\hline solrad_tmax 5 & Basin maximum air temperature for use with solar radiation calculations & one & temp_units & real & always \\
\hline solrad_tmin 5 & Basin minimum air temperature for use with solar radiation calculations & one & temp_units & real & always \\
\hline subinc_swrad & $\begin{array}{l}\text { Area-weighted average shortwave radiation distributed to associated HRUs of } \\
\text { each subbasin }\end{array}$ & nsub & Langleys & double & subbasin_flag $=1$ \\
\hline swrad & Shortwave radiation distributed to each HRU & nhru & Langleys & real & always \\
\hline \multicolumn{6}{|c|}{ Interception } \\
\hline basin_intcp_evap & Basin area-weighted evaporation from the canopy & one & inches & double & always \\
\hline basin_intcp_evap_mo & Monthly area-weighted average interception evaporation & one & inches & double & always \\
\hline basin_intcp_stor & Basin area-weighted average interception storage & one & inches & double & always \\
\hline hru_intcpevap & Evaporation from the canopy for each HRU & nhru & inches & real & always \\
\hline hru_intcpstor & Interception storage in the canopy for each HRU & nhru & inches & real & always \\
\hline intcp_form & Form (rain or snow) of interception for each HRU & nhru & none & integer & always \\
\hline intcp_on & Flag indicating interception storage for each HRU $(0=$ no; $1=$ yes $)$ & nhru & none & integer & always \\
\hline intcp_stor & Interception storage in canopy for cover density for each HRU & nhru & inches & real & always \\
\hline last_intcp_stor & Basin area-weighted average changeover interception storage & one & inches & double & always \\
\hline net_ppt & Precipitation (rain and/or snow) that falls through the canopy for each HRU & nhru & inches & real & always \\
\hline net_rain & Rain that falls through canopy for each HRU & nhru & inches & real & always \\
\hline net_snow & Snow that falls through canopy for each HRU & nhru & inches & real & always \\
\hline \multicolumn{6}{|c|}{ Snow computations } \\
\hline albedo & $\begin{array}{l}\text { Snow surface albedo or the fraction of radiation reflected from the snowpack } \\
\text { surface for each HRU }\end{array}$ & nhru & decimal fraction & real & always \\
\hline basin_pk_precip & Basin area-weighted average precipitation added to snowpack & one & inches & double & always \\
\hline basin_pweqv & Basin area-weighted average snowpack water equivalent & one & inches & double & always \\
\hline
\end{tabular}


[HRU, hydrologic response unit; GWR, groundwater reservoir; $C B H$, climate-by-HRU; ET, evapotranspiration; cfs: cubic feet per second; cms: cubic meters per second; $>$, greater than; runoff_units, $0=c f s$; $1=\mathrm{cms}$; precip_units, $0=$ inches; $1=$ millimeters; temp_units, $0=$ degrees Fahrenheit; $1=$ degrees Celsius; control parameters temp_module, precip_module, et_module, strmflow_module, model_mode, dprst_ flag, subbasin_flag, cascade_flag, and cascadegw_flag defined in table 1-2]

\begin{tabular}{|c|c|c|c|c|c|}
\hline Variable name & Description & Dimension $^{1}$ & Units & Data type & Availabilty/condition \\
\hline basin_snowcov & Basin area-weighted average snow-covered area & one & decimal fraction & double & always \\
\hline basin_snowevap & Basin area-weighted average evaporation and sublimation & one & inches & double & always \\
\hline basin_snowmelt & Basin area-weighted average snowmelt & one & inches & double & always \\
\hline basin_snowmelt_mo & Monthly area-weighted average snowmelt & one & inches & double & always \\
\hline freeh $2 o$ & Storage of free liquid water in the snowpack on each HRU & nhru & inches & real & always \\
\hline$i a s w$ & $\begin{array}{l}\text { Flag indicating that snow covered area is interpolated between previous location } \\
\text { on curve and maximum (1), or is on the defined curve }(0)\end{array}$ & nhru & none & integer & always \\
\hline iso & $\begin{array}{l}\text { Flag to indicate if time is before (1) or after (2) the day to force melt season } \\
\text { (melt_force) }\end{array}$ & nhru & none & integer & always \\
\hline lso & $\begin{array}{l}\text { Counter for tracking the number of days the snowpack is at or above } 0 \text { degrees } \\
\text { Celsius }\end{array}$ & nhru & $\begin{array}{l}\text { number of itera- } \\
\text { tions }\end{array}$ & integer & always \\
\hline lst & $\begin{array}{l}\text { Flag indicating whether there was new snow that was insufficient to reset the } \\
\text { albedo curve (1) (albset_snm or albset_sna), otherwise (0) }\end{array}$ & nhru & none & integer & always \\
\hline mso & $\begin{array}{l}\text { Flag to indicate if time is before (1) or after (2) the first potential day for melt } \\
\text { season (melt_look) }\end{array}$ & nhru & none & integer & always \\
\hline$p k \_d e f$ & $\begin{array}{l}\text { Heat deficit, amount of heat necessary to make the snowpack isothermal at } 0 \\
\text { degrees Celsius }\end{array}$ & nhru & Langleys & real & always \\
\hline$p k \_d e n$ & Density of the snowpack on each HRU & nhru & $\begin{array}{l}\text { grams/cubic } \\
\text { centimeters }\end{array}$ & real & always \\
\hline pk_depth & Depth of snowpack on each HRU & nhru & inches & real & always \\
\hline pk_ice & Storage of frozen water in the snowpack on each HRU & nhru & inches & real & always \\
\hline pk_precip & Precipitation added to snowpack for each HRU & nhru & inches & real & always \\
\hline pk_temp & Temperature of the snowpack on each HRU & nhru & temp_units & real & always \\
\hline pkwater_ante & Antecedent snowpack water equivalent on each HRU & nhru & inches & real & always \\
\hline pkwater_equiv & Snowpack water equivalent on each HRU & nhru & inches & real & always \\
\hline pptmix_nopack & $\begin{array}{l}\text { Flag indicating that a mixed precipitation event has occurred with no snowpack } \\
\text { present on an HRU (1), otherwise }(0)\end{array}$ & nhru & none & integer & always \\
\hline pss & Previous snowpack water equivalent plus new snow & nhru & inches & real & always \\
\hline pst & $\begin{array}{l}\text { While a snowpack exists, } p s t \text { tracks the maximum snow water equivalent of that } \\
\text { snowpack }\end{array}$ & nhru & inches & real & always \\
\hline snow & Snow depth at each measurement station & nsnow & inches & real & nsnow $>0$ \\
\hline snow_evap & Evaporation and sublimation from snowpack on each HRU & nhru & inches & real & always \\
\hline snow free & Fraction of snow-free surface for each HRU & nhru & decimal fraction & real & always \\
\hline
\end{tabular}


Table 1-5. Input and output variables for the Precipitation-Runoff Modeling System, version 4 (PRMS-IV).-Continued

[HRU, hydrologic response unit; GWR, groundwater reservoir; $C B H$, climate-by-HRU; ET, evapotranspiration; cfs: cubic feet per second; cms: cubic meters per second; >, greater than; runoff units, $0=c f s$; $1=$ cms; precip_units, $0=$ inches; $1=$ millimeters; temp_units, $0=$ degrees Fahrenheit; $1=$ degrees Celsius; control parameters temp_module, precip_module, et_module, strmflow_module, model_mode, dprst_ flag, subbasin_flag, cascade_flag, and cascadegw_flag defined in table 1-2]

\begin{tabular}{|c|c|c|c|c|c|}
\hline Variable name & Description & Dimension' & Units & Data type & Availabilty/condition \\
\hline snowcov_area & Snow-covered area on each HRU & nhru & decimal fraction & real & always \\
\hline snowmelt & Snowmelt from snowpack on each HRU & nhru & inches & real & always \\
\hline snsv & $\begin{array}{l}\text { Tracks the cumulative amount of new snow until there is enough to reset the } \\
\text { albedo curve (albset_snm or albset_sna) }\end{array}$ & nhru & inches & real & always \\
\hline subinc pkweqv & $\begin{array}{l}\text { Area-weighted average snowpack water equivalent from associated HRUs } \\
\text { of each subbasin }\end{array}$ & nsub & inches & double & subbasin_flag $=1$ \\
\hline subinc_snowcov & $\begin{array}{l}\text { Area-weighted average snow-covered area from associated HRUs to each } \\
\text { subbasin }\end{array}$ & nsub & decimal fraction & double & subbasin_flag = 1 \\
\hline subinc_snowmelt & Area-weighted average snowmelt from associated HRUs of each subbasin & nsub & inches & double & subbasin_flag $=1$ \\
\hline tcal & Net snowpack energy balance on each HRU & nhru & Langleys & real & always \\
\hline \multicolumn{6}{|c|}{ Evapotranspiration } \\
\hline basin_actet & Basin area-weighted average actual ET & one & inches & double & always \\
\hline basin_actet_mo & Monthly area-weighted average actual ET & one & inches & double & always \\
\hline basin_dprst_evap & Basin area-weighted average evaporation from surface depression storage & one & inches & double & dprst_flag $=1$ \\
\hline basin_fall_frost & Basin area-weighted average fall frost & one & solar date & real & $\begin{array}{l}\text { model_mode }= \\
\quad \text { FROST }\end{array}$ \\
\hline basin_imperv_evap & Basin area-weighted average evaporation from impervious area & one & inches & double & always \\
\hline basin_lakeevap & Basin area-weighted average lake evaporation & one & inches & double & nlake $>0$ \\
\hline basin_perv_et & Basin area-weighted average ET from capillary reservoirs & one & inches & double & always \\
\hline basin_potet & Basin area-weighted average potential ET & one & inches & double & always \\
\hline basin_potet_mo & Monthly area-weighted average potential ET & one & inches & double & always \\
\hline basin_spring_frost & Basin area-weighted average spring frost & one & solar date & real & $\begin{array}{l}\text { model_mode }= \\
\quad \text { FROST }\end{array}$ \\
\hline basin_swale_et & Basin area-weighted average ET from swale HRUs & one & inches & double & always \\
\hline basin_transp_on & $\begin{array}{l}\text { Flag indicating whether transpiration is occurring anywhere in the basin } \\
\qquad(0=\text { no; } 1=\text { yes })\end{array}$ & one & none & integer & always \\
\hline fall_frost & $\begin{array}{l}\text { The solar date (number of days after winter solstice) of the first killing frost } \\
\text { of the fall }\end{array}$ & nhru & solar date & real & $\begin{array}{l}\text { model_mode }= \\
\quad \text { FROST }\end{array}$ \\
\hline hru_actet & Actual ET for each HRU & nhru & inches & real & always \\
\hline hru_et_yr & Yearly area-weighted average actual ET for each HRU & nhru & inches & real & print_freq $=2$ \\
\hline hru_frac_perv & Fraction of HRU that is pervious & nhru & decimal fraction & real & always \\
\hline imperv_evap & Evaporation from impervious area for each HRU & nhru & inches & real & always \\
\hline
\end{tabular}


Table 1-5. Input and output variables for the Precipitation-Runoff Modeling System, version 4 (PRMS-IV). - Continued

[HRU, hydrologic response unit; GWR, groundwater reservoir; CBH, climate-by-HRU; ET, evapotranspiration; cfs: cubic feet per second; cms: cubic meters per second; >, greater than; runoff_units, $0=c f s ;$ $1=\mathrm{cms}$; precip_units, $0=$ inches; $1=$ millimeters; temp_units, $0=$ degrees Fahrenheit; $1=$ degrees Celsius; control parameters temp_module, precip_module, et_module, strmflow_module, model_mode, dprst_ flag, subbasin flag, cascade flag, and cascadegw flag defined in table 1-2]

\begin{tabular}{|c|c|c|c|c|c|}
\hline Variable name & Description & Dimension $^{1}$ & Units & Data type & Availabilty/condition \\
\hline intcp_evap & Evaporation from the canopy for each HRU & nhru & inches & real & always \\
\hline lake_evap & Total evaporation from each lake HRU & nlake & $\operatorname{cfs}$ & double & nlake $>0$ \\
\hline pan_evap & Pan evaporation at each measurement station & nevap & inches & real & nevap $>0$ \\
\hline perv_actet & Actual ET from the capillary reservoir of each HRU & nhru & inches & real & always \\
\hline potet & Potential ET for each HRU & nhru & inches & real & always \\
\hline potet_lower & Potential ET in the lower zone of the capillary reservoir for each HRU & nhru & inches & real & always \\
\hline potet_rechr & Potential ET in the recharge zone of the capillary reservoir for each HRU & nhru & inches & real & always \\
\hline spring_frost & $\begin{array}{l}\text { The solar date (number of days after winter solstice) of the last killing frost of the } \\
\text { spring }\end{array}$ & nhru & solar date & real & $\begin{array}{l}\text { model_mode }= \\
\quad \text { FROST }\end{array}$ \\
\hline subinc_actet & Area-weighted average actual ET from associated HRUs to each subbasin & nsub & inches & double & subbasin_flag = 1 \\
\hline subinc potet & Area-weighted average potential ET from associated HRUs to each subbasin & nsub & inches & double & subbasin_flag $=1$ \\
\hline swale_actet & $\begin{array}{l}\text { Evaporation from the gravity and preferential-flow reservoirs that exceeds sat_ } \\
\text { threshold }\end{array}$ & nhru & inches & real & always \\
\hline transp_on & Flag indicating whether transpiration is occurring $(0=$ no; $1=$ yes $)$ & nhru & none & integer & always \\
\hline \multicolumn{6}{|c|}{ Hortonian surface runoff, infiltration, and impervious storage } \\
\hline basin_cap_infil_max & Basin area-weighted average maximum infiltration that flows to capillary reservoirs & one & inches & double & always \\
\hline basin_hortonian & Basin area-weighted average Hortonian runoff & one & inches & double & always \\
\hline basin_hortonian_lakes & Basin area-weighted average Hortonian surface runoff to lakes & one & inches & double & $\begin{aligned} \text { cascade_flag } & =1 \text { and } \\
\text { ncascade } & >0\end{aligned}$ \\
\hline basin_imperv_stor & Basin area-weighted average storage on impervious area & one & inches & double & always \\
\hline basin_infil & Basin area-weighted average infiltration to the capillary reservoirs & one & inches & double & always \\
\hline basin_sroff & Basin area-weighted average surface runoff to the stream network & one & inches & double & always \\
\hline basin_sroff_cfs & Basin area-weighted average surface runoff to the stream network & one & $\mathrm{cfs}$ & double & always \\
\hline basin_sroff_down & Basin area-weighted average cascading surface runoff & one & inches & double & $\begin{aligned} \text { cascade_flag } & =1 \text { and } \\
\text { ncascade } & >0\end{aligned}$ \\
\hline basin_sroff_farflow & Basin area-weighted average cascading surface runoff to farfield & one & inches & double & $\begin{aligned} \text { cascade_flag } & =1 \text { and } \\
\text { ncascade } & >0\end{aligned}$ \\
\hline basin_sroff_mo & Monthly area-weighted average surface runoff & one & inches & double & always \\
\hline basin_sroff_upslope & $\begin{array}{l}\text { Basin area-weighted average cascading surface runoff received from upslope } \\
\text { HRUs }\end{array}$ & one & inches & double & $\begin{aligned} \text { cascade_flag } & =1 \text { and } \\
\text { ncascade } & >0\end{aligned}$ \\
\hline basin_sroffi & Basin area-weighted average surface runoff from impervious areas & one & inches & double & always \\
\hline basin_sroffp & Basin area-weighted average surface runoff from pervious areas & one & inches & double & always \\
\hline
\end{tabular}


Table 1-5. Input and output variables for the Precipitation-Runoff Modeling System, version 4 (PRMS-IV).-Continued

[HRU, hydrologic response unit; GWR, groundwater reservoir; $C B H$, climate-by-HRU; ET, evapotranspiration; cfs: cubic feet per second; cms: cubic meters per second; >, greater than; runoff units, $0=c f s$; $1=\mathrm{cms}$; precip_units, $0=$ inches; $1=$ =millimeters; temp_units, $0=$ degrees Fahrenheit; $1=$ degrees Celsius; control parameters temp_module, precip_module, et_module, strmflow_module, model_mode, dprst_ flag, subbasin_flag, cascade_flag, and cascadegw_flag defined in table 1-2]

\begin{tabular}{|c|c|c|c|c|c|}
\hline Variable name & Description & Dimension'1 & Units & Data type & Availabilty/condition \\
\hline hortonian_flow & Hortonian surface runoff reaching stream network for each HRU & nhru & inches & real & always \\
\hline hortonian_lakes & Surface runoff to lakes for each HRU & nhru & inches & real & $\begin{array}{c}\text { cascade_flag }=1, \\
\text { ncascade }>0 \text {, and } \\
\text { nlake }>0\end{array}$ \\
\hline hru_hortn_cascflow & Cascading Hortonian surface runoff leaving each HRU & nhru & inches & real & $\begin{aligned} \text { cascade_flag } & =1 \text { and } \\
\text { ncascade } & >0\end{aligned}$ \\
\hline hru_impervevap & Evaporation from impervious area for each HRU & nhru & inches & real & always \\
\hline hru_impervstor & Storage on impervious area for each HRU & nhru & inches & real & always \\
\hline hru_sroffi & Surface runoff from impervious areas for each HRU & nhru & inches & real & always \\
\hline$h r u \_s r o f f p$ & Surface runoff from pervious areas for each HRU & nhru & inches & real & always \\
\hline imperv_stor & Storage on impervious area for each HRU & nhru & inches & real & always \\
\hline infil & Infiltration to the capillary reservoir for each HRU & nhru & inches & real & always \\
\hline infil_tot & $\begin{array}{l}\text { Infiltration and cascading interflow and Dunnian flow added to capillary reservoir } \\
\text { storage for each HRU }\end{array}$ & nhru & inches & real & always \\
\hline seginc_sroff & $\begin{array}{l}\text { Area-weighted average surface runoff for each segment from HRUs contributing } \\
\text { flow to the segment }\end{array}$ & nsegment & $\mathrm{cfs}$ & real & nsegment $>0$ \\
\hline sroff $^{3}$ & Surface runoff to the stream network for each HRU & nhru & inches & real & always \\
\hline sub_sroff & $\begin{array}{l}\text { Area-weighted average Hortonian plus Dunnian surface runoff from associated } \\
\text { HRUs to each subbasin and from upstream subbasins }\end{array}$ & nsub & $\mathrm{cfs}$ & double & subbasin_flag $=1$ \\
\hline subinc_sroff & $\begin{array}{l}\text { Area-weighted average Hortonian plus Dunnian surface runoff from associated } \\
\text { HRUs to each subbasin }\end{array}$ & nsub & $\mathrm{cfs}$ & double & subbasin_flag $=1$ \\
\hline upslope_hortonian & Hortonian surface runoff received from upslope HRUs & nhru & inches & real & $\begin{array}{c}\text { cascade_flag }=1 \text { and } \\
\text { ncascade }>0\end{array}$ \\
\hline \multicolumn{6}{|c|}{ Surface depression storage } \\
\hline basin_dprst_seep & Basin area-weighted average seepage surface depression storage & one & inches & double & dprst_flag $=1$ \\
\hline basin_dprst_sroff & Basin area-weighted average surface runoff from open surface depression storage & one & inches & double & dprst_flag $=1$ \\
\hline basin_dprst_volcl & Basin area-weighted average storage volume in closed surface depressions & one & inches & double & dprst_flag $=1$ \\
\hline basin_dprst_volop & Basin area-weighted average storage volume in open surface depressions & one & inches & double & dprst_flag $=1$ \\
\hline dprst_area_clos & Surface area of closed surface depressions based on volume for each HRU & nhru & acres & real & dprst_flag $=1$ \\
\hline dprst_area_open & Surface area of open surface depressions based on volume for each HRU & nhru & acres & real & dprst_flag $=1$ \\
\hline dprst_evap_hru & Evaporation from surface depression storage for each HRU & nhru & inches & real & dprst_flag $=1$ \\
\hline dprst_frac_hru & Fraction of HRU that has surface-depression storage & nhru & decimal fraction & real & dprst_flag $=1$ \\
\hline dprst_frac_perv & Fraction of HRU that has surface-depression storage & nhru & decimal fraction & real & dprst_flag $=1$ \\
\hline
\end{tabular}


Table 1-5. Input and output variables for the Precipitation-Runoff Modeling System, version 4 (PRMS-IV).—Continued

[HRU, hydrologic response unit; GWR, groundwater reservoir; CBH, climate-by-HRU; ET, evapotranspiration; cfs: cubic feet per second; cms: cubic meters per second; >, greater than; runoff_units, $0=c f s ;$ $1=\mathrm{cms}$; precip_units, $0=$ inches; $1=$ millimeters; temp_units, $0=$ degrees Fahrenheit; $1=$ degrees Celsius; control parameters temp_module, precip_module, et_module, strmflow_module, model_mode, dprst_ flag, subbasin_flag, cascade flag, and cascadegw_flag defined in table 1-2]

\begin{tabular}{|c|c|c|c|c|c|}
\hline Variable name & Description & Dimension $^{1}$ & Units & Data type & Availabilty/condition \\
\hline dprst_insroff_hru & $\begin{array}{l}\text { Surface runoff from pervious and impervious portions into surface depression } \\
\text { storage for each HRU }\end{array}$ & nhru & inches & real & dprst_flag $=1$ \\
\hline dprst_seep_hru & Seepage from surface depression storage to associated GWR for each HRU & nhru & inches & real & dprst_flag $=1$ \\
\hline dprst_sroff_hru & Surface runoff from open surface depression storage for each HRU & nhru & inches & real & dprst_flag $=1$ \\
\hline dprst_vol_clos & Storage volume in closed surface depressions for each HRU & nhru & acre-inches & double & dprst_flag $=1$ \\
\hline dprst_vol_open & Storage volume in open surface depressions for each HRU & nhru & acre-inches & double & dprst_flag $=1$ \\
\hline \multicolumn{6}{|c|}{ Soil zone storage, interflow, gravity drainage, dunnian surface runoff } \\
\hline basin_cap_up_max & $\begin{array}{l}\text { Basin area-weighted average maximum cascade flow that flows to capillary } \\
\text { reservoirs }\end{array}$ & one & inches & double & $\begin{aligned} \text { cascade_flag } & =1 \text { and } \\
\text { ncascade } & >0\end{aligned}$ \\
\hline basin_capwaterin & $\begin{array}{l}\text { Basin area-weighted average infiltration and any cascading interflow and Dunnian } \\
\text { flow added to capillary reservoir storage }\end{array}$ & one & inches & double & always \\
\hline basin_dncascadeflow & $\begin{array}{l}\text { Basin area-weighted average cascading interflow, Dunnian surface runoff, and } \\
\text { farflow }\end{array}$ & one & inches & double & $\begin{aligned} \text { cascade_flag } & =1 \text { and } \\
\text { ncascade } & >0\end{aligned}$ \\
\hline basin_dninterflow & Basin area-weighted average cascading interflow & one & inches & double & $\begin{aligned} \text { cascade_flag } & =1 \text { and } \\
\text { ncascade } & >0\end{aligned}$ \\
\hline basin_dunnian & $\begin{array}{l}\text { Basin area-weighted average Dunnian surface runoff that flows to the stream } \\
\text { network }\end{array}$ & one & inches & double & always \\
\hline basin_dunnian_gvr & $\begin{array}{l}\text { Basin area-weighted average excess flow to preferential-flow reservoirs from } \\
\text { gravity reservoirs }\end{array}$ & one & inches & double & always \\
\hline basin_dunnian_pfr & $\begin{array}{l}\text { Basin area-weighted average excess infiltration to preferential-flow reservoirs } \\
\text { from variable infil }\end{array}$ & one & inches & double & always \\
\hline basin_dunnianflow & Basin area-weighted average cascading Dunnian flow & one & inches & double & always \\
\hline basin_gvr2pfr & $\begin{array}{l}\text { Basin area-weighted average excess flow to preferential-flow reservoir storage } \\
\text { from gravity reservoirs }\end{array}$ & one & inches & double & always \\
\hline basin_interflow_max & $\begin{array}{l}\text { Basin area-weighted average maximum interflow that flows from gravity } \\
\text { reservoirs }\end{array}$ & one & inches & double & always \\
\hline basin_lakeinsz & Basin area-weighted average lake inflow from land HRUs & one & inches & double & $\begin{array}{c}\text { cascade_flag }=1, \\
\text { ncascade }>0, \text { and } \\
\text { nlake }>0\end{array}$ \\
\hline basin_pref_flow_in & Basin area-weighted average infiltration to preferential-flow reservoir storage & one & inches & double & always \\
\hline basin_pref_stor & Basin area-weighted average storage in preferential-flow reservoirs & one & inches & double & always \\
\hline basin_prefflow & $\begin{array}{l}\text { Basin area-weighted average interflow from preferential-flow reservoirs to the } \\
\text { stream network }\end{array}$ & one & inches & double & always \\
\hline basin_recharge & Basin area-weighted average recharge to GWRs & one & inches & double & always \\
\hline
\end{tabular}


Table 1-5. Input and output variables for the Precipitation-Runoff Modeling System, version 4 (PRMS-IV).-Continued

[HRU, hydrologic response unit; GWR, groundwater reservoir; $C B H$, climate-by-HRU; ET, evapotranspiration; cfs: cubic feet per second; cms: cubic meters per second; >, greater than; runoff units, $0=c f s$; $1=$ cms; precip_units, $0=$ inches; $1=$ =millimeters; temp_units, $0=$ degrees Fahrenheit; $1=$ degrees Celsius; control parameters temp_module, precip_module, et_module, strmflow_module, model_mode, dprst_ flag, subbasin_flag, cascade_flag, and cascadegw_flag defined in table 1-2]

\begin{tabular}{|c|c|c|c|c|c|}
\hline Variable name & Description & Dimension $^{1}$ & Units & Data type & Availabilty/condition \\
\hline basin_slowflow & $\begin{array}{l}\text { Basin area-weighted average interflow from gravity reservoirs to the stream } \\
\text { network }\end{array}$ & one & inches & double & always \\
\hline basin_slstor & Basin area-weighted average storage of gravity reservoirs & one & inches & double & always \\
\hline basin_sm2gvr & $\begin{array}{l}\text { Basin area-weighted average excess flow from capillary reservoirs to gravity } \\
\text { reservoir storage }\end{array}$ & one & inches & double & always \\
\hline basin_sm2gvr_max & $\begin{array}{l}\text { Basin area-weighted average maximum excess flow from capillary reservoirs that } \\
\text { flows to gravity reservoirs }\end{array}$ & one & inches & double & always \\
\hline basin_soil_moist & Basin area-weighted average capillary reservoir storage & one & inches & double & always \\
\hline basin_soil_rechr & $\begin{array}{l}\text { Basin area-weighted average storage for recharge zone; upper portion of capillary } \\
\text { reservoir where both evaporation and transpiration occurs }\end{array}$ & one & inches & double & always \\
\hline basin_soil_to_gw & $\begin{array}{l}\text { Basin area-weighted average excess flow to capillary reservoirs that drains to } \\
\text { GWRs }\end{array}$ & one & inches & double & always \\
\hline basin_ssflow & $\begin{array}{l}\text { Basin area-weighted average interflow from gravity and preferential-flow reser- } \\
\text { voirs to the stream network }\end{array}$ & one & inches & double & always \\
\hline basin_ssflow_cfs & $\begin{array}{l}\text { Basin area-weighted average interflow from gravity and preferential-flow reser- } \\
\text { voirs to the stream network }\end{array}$ & one & $\mathrm{cfs}$ & double & always \\
\hline basin_ssflow_mo & Monthly area-weighted average interflow & one & inches & double & always \\
\hline basin_ssin & $\begin{array}{l}\text { Basin area-weighted average inflow to gravity and preferential-flow reservoir } \\
\text { storage }\end{array}$ & one & inches & double & always \\
\hline basin_ssstor & Basin area-weighted average gravity and preferential-flow reservoir storage & one & inches & double & always \\
\hline basin_sz2gw & Basin area-weighted average drainage from gravity reservoirs to GWRs & one & inches & double & always \\
\hline basin_szfarflow & $\begin{array}{l}\text { Basin area-weighted average farfield flow from gravity and preferential-flow } \\
\text { reservoirs }\end{array}$ & one & inches & double & $\begin{aligned} \text { cascade_flag } & =1 \text { and } \\
\text { ncascade } & >0\end{aligned}$ \\
\hline cap_waterin & $\begin{array}{l}\text { Infiltration and any cascading interflow and Dunnian surface runoff added to } \\
\text { capillary reservoir storage for each HRU }\end{array}$ & nhru & inches & real & always \\
\hline dunnian_flow & Dunnian surface runoff that flows to the stream network for each HRU & nhru & inches & real & always \\
\hline hru_sz_cascadeflow & Cascading interflow, Dunnian surface runoff, and farflow from each HRU & nhru & inches & real & $\begin{aligned} \text { cascade_flag } & =1 \text { and } \\
\text { ncascade } & >0\end{aligned}$ \\
\hline lakein_sz & $\begin{array}{l}\text { Cascading interflow and Dunnian surface runoff to lake HRUs for each upslope } \\
\text { HRU }\end{array}$ & nhru & inches & real & $\begin{array}{c}\text { cascade_flag }=1, \\
\text { ncascade }>0, \text { and } \\
\text { nlake }>0\end{array}$ \\
\hline pref_flow & $\begin{array}{l}\text { Interflow from the preferential-flow reservoir that flows to the stream network for } \\
\text { each HRU }\end{array}$ & nhru & inches & real & always \\
\hline pref_flow_infil & Infiltration to the preferential-flow reservoir storage for each HRU & nhru & inches & real & always \\
\hline
\end{tabular}


[HRU, hydrologic response unit; GWR, groundwater reservoir; $C B H$, climate-by-HRU; ET, evapotranspiration; cfs: cubic feet per second; cms: cubic meters per second; $>$, greater than; runoff_units, $0=c f s$; $1=\mathrm{cms}$; precip_units, $0=$ inches; $1=$ millimeters; temp_units, $0=$ degrees Fahrenheit; $1=$ degrees Celsius; control parameters temp_module, precip_module, et_module, strmflow_module, model_mode, dprst_ flag, subbasin flag, cascade flag, and cascadegw flag defined in table 1-2]

\begin{tabular}{|c|c|c|c|c|c|}
\hline Variable name & Description & Dimension ${ }^{1}$ & Units & Data type & Availabilty/condition \\
\hline pref_flow_max & Maximum storage of the preferential-flow reservoir for each HRU & nhru & inches & real & always \\
\hline pref_flow_stor & Storage in preferential-flow reservoir for each HRU & nhru & inches & real & always \\
\hline pref_flow_thrsh & $\begin{array}{l}\text { Soil storage threshold defining storage between field capacity and maximum soil } \\
\text { saturation minus the any' preferential-flow storage }\end{array}$ & nhru & inches & real & always \\
\hline recharge & $\begin{array}{l}\text { Recharge to the associated GWR as sum of soil_to } g w \text { and'ssr_to } \_w w \text { for each } \\
\text { HRU }\end{array}$ & nhru & inches & real & always \\
\hline seginc_ssflow & $\begin{array}{l}\text { Area-weighted average interflow for each segment from HRUs contributing flow } \\
\text { to the segment }\end{array}$ & nsegment & $\mathrm{cfs}$ & real & nsegment $>0$ \\
\hline slow flow & Interflow from gravity reservoir that flows to the stream network for each HRU & nhru & inches & real & always \\
\hline slow_stor & Storage of gravity reservoir for each HRU & nhru & inches & real & always \\
\hline soil_lower & $\begin{array}{l}\text { Storage in the lower zone of the capillary reservoir that is only available for tran- } \\
\text { spiration for each HRU }\end{array}$ & nhru & inches & real & always \\
\hline soil_lower_ratio & Water content ration in the lower zone of the capillary reservoir for each HRU & nhru & decimal fraction & real & always \\
\hline soil_moist & Storage of capillary reservoir for each HRU & nhru & inches & real & always \\
\hline soil_moist_frac & Fraction of capillary reservoir storage of the maximum storage for each HRU & nhru & decimal fraction & real & always \\
\hline soil_moist_tot & Total soil-zone storage (soil_moist + ssres_stor) for each HRU & nhru & inches & real & always \\
\hline soil_rechr & $\begin{array}{l}\text { Storage for recharge zone (upper portion) of the capillary reservoir that is avail- } \\
\text { able for both evaporation and transpiration }\end{array}$ & nhru & inches & real & always \\
\hline soil_rechr_ratio & Water content ration in the recharge zone of the capillary reservoir for each HRU & nhru & decimal fraction & real & always \\
\hline soil_to_gw & $\begin{array}{l}\text { Portion of excess flow to the capillary reservoir that drains to the associated GWR } \\
\text { for each HRU }\end{array}$ & nhru & inches & real & always \\
\hline soil_to_ssr & $\begin{array}{l}\text { Portion of excess flow to the capillary reservoir that flows to the gravity reservoir } \\
\text { for each HRU }\end{array}$ & nhru & inches & real & always \\
\hline soil_zone_max & Maximum storage of all soil zone reservoirs & nhru & inches & real & always \\
\hline ssr_to_gw & Drainage from the gravity-reservoir to the associated GWR for each HRU & nssr & inches & real & always \\
\hline ssres_flow & $\begin{array}{l}\text { Interflow from gravity and preferential-flow reservoirs to the stream network for } \\
\text { each HRU }\end{array}$ & nssr & inches & real & always \\
\hline ssres_in & Inflow to the gravity and preferential-flow reservoirs for each HRU & nssr & inches & real & always \\
\hline ssres_stor & Storage in the gravity and preferential-flow reservoirs for each HRU & nssr & inches & real & always \\
\hline sub_interflow & $\begin{array}{l}\text { Area-weighted average interflow from associated HRUs to each subbasin and } \\
\text { from upstream subbasins }\end{array}$ & nsub & $\mathrm{cfs}$ & double & subbasin_flag $=1$ \\
\hline subinc_interflow & Area-weighted average interflow from associated HRUs to each subbasin & nsub & $\mathrm{cfs}$ & double & subbasin_flag $=1$ \\
\hline
\end{tabular}


Table 1-5. Input and output variables for the Precipitation-Runoff Modeling System, version 4 (PRMS-IV).-Continued

[HRU, hydrologic response unit; GWR, groundwater reservoir; $\mathrm{CBH}$, climate-by-HRU; $\mathrm{ET}$, evapotranspiration; cfs: cubic feet per second; cms: cubic meters per second; $>$, greater than; runoff units, $0=$ cfs; $1=\mathrm{cms}$; precip_units, $0=$ inches; $1=$ =millimeters; temp_units, $0=$ degrees Fahrenheit; $1=$ degrees Celsius; control parameters temp_module, precip_module, et_module, strmflow_module, model_mode, dprst_ flag, subbasin_flag, cascade_flag, and cascadegw_flag defined in table 1-2]

\begin{tabular}{|c|c|c|c|c|c|}
\hline Variable name & Description & Dimension ${ }^{1}$ & Units & Data type & Availabilty/condition \\
\hline upslope_dunnianflow & $\begin{array}{l}\text { Cascading Dunnian surface runoff that flows to the capillary reservoir of each } \\
\text { down slope HRU for each upslope HRU }\end{array}$ & nhru & inches & real & $\begin{aligned} \text { cascade_flag } & =1 \text { and } \\
\text { ncascade } & >0\end{aligned}$ \\
\hline upslope_interflow & $\begin{array}{l}\text { Cascading interflow runoff that flows to the capillary reservoir of each down slope } \\
\text { HRU for each upslope HRU }\end{array}$ & nhru & inches & real & $\begin{aligned} \text { cascade_flag } & =1 \text { and } \\
\text { ncascade } & >0\end{aligned}$ \\
\hline \multicolumn{6}{|c|}{ Groundwater flow } \\
\hline basin_gwflow & Basin area-weighted average groundwater flow to the stream network & one & inches & double & always \\
\hline basin_gwflow_cfs & Basin area-weighted average groundwater flow to the stream network & one & $\mathrm{cfs}$ & double & always \\
\hline basin_gwflow_mo & Monthly area-weighted average groundwater discharge & one & inches & double & always \\
\hline basin_gwin & Basin area-weighted average inflow to GWRs & one & inches & double & always \\
\hline basin_gwsink & Basin area-weighted average GWR outflow to the groundwater sink & one & inches & double & always \\
\hline basin_gwstor & Basin area-weighted average storage in GWRs & one & inches & double & always \\
\hline$g w \_i n \_s o i l$ & Drainage from capillary reservoir excess water for each GWR & ngw & acre-inches & real & always \\
\hline$g w \_i n \_s s r$ & Drainage from gravity reservoir excess water for each GWR & ngw & acre-inches & real & always \\
\hline gw_seep_lakein & Groundwater discharge to each lake HRU for each GWR & nlake & inches & real & $\begin{array}{l}\text { strmflow_module }= \\
\text { strmflow_lake }\end{array}$ \\
\hline gw_upslope & Groundwater flow received from upslope GWRs for each GWR & ngw & acre-inches & real & $\begin{array}{l}\text { cascadegw_flag }=1 \\
\text { and ncascdgw }>0\end{array}$ \\
\hline gwres_flow & Groundwater discharge from each GWR to the stream network & ngw & inches & real & always \\
\hline gwres_in & Total inflow to each GWR from associated capillary and gravity reservoirs & ngw & acre-inches & real & always \\
\hline gwres_sink & $\begin{array}{l}\text { Outflow from GWRs to the groundwater sink; water is considered underflow or } \\
\text { flow to deep aquifers and does not flow to the stream network }\end{array}$ & ngw & inches & real & always \\
\hline gwres_stor & Storage in each GWR & ngw & inches & real & always \\
\hline gwstor_minarea_wb & Storage added to each GWR when storage is less than gwstor_min & ngw & inches & real & always \\
\hline hru_gw_cascadeflow & Cascading groundwater flow from each GWR & ngw & inches & real & $\begin{array}{l}\text { cascadegw_flag }=1 \\
\text { and ncascdgw }>0\end{array}$ \\
\hline seginc_gwflow & $\begin{array}{l}\text { Area-weighted average groundwater discharge for each segment from HRUs } \\
\text { contributing flow to the segment }\end{array}$ & nsegment & $\mathrm{cfs}$ & real & nsegment $>0$ \\
\hline sub_gwflow & $\begin{array}{l}\text { Area-weighted average groundwater discharge from associated GWRs to each } \\
\text { subbasin and from upstream subbasins }\end{array}$ & nsub & $\mathrm{cfs}$ & double & subbasin_flag $=1$ \\
\hline subinc_gwflow & $\begin{array}{l}\text { Area-weighted average groundwater discharge from associated GWRs to each } \\
\text { subbasin }\end{array}$ & nsub & $\mathrm{cfs}$ & double & subbasin_flag $=1$ \\
\hline
\end{tabular}


Table 1-5. Input and output variables for the Precipitation-Runoff Modeling System, version 4 (PRMS-IV).—Continued

[HRU, hydrologic response unit; GWR, groundwater reservoir; $C B H$, climate-by-HRU; ET, evapotranspiration; cfs: cubic feet per second; cms: cubic meters per second; $>$, greater than; runoff_units, $0=c f s$; $1=\mathrm{cms}$; precip_units, $0=$ inches; $1=$ millimeters; temp_units, $0=$ degrees Fahrenheit; $1=$ degrees Celsius; control parameters temp_module, precip_module, et_module, strmflow_module, model_mode, dprst_ flag, subbasin_flag, cascade flag, and cascadegw_flag defined in table 1-2]

\begin{tabular}{|c|c|c|c|c|c|}
\hline Variable name & Description & Dimension' ${ }^{1}$ & Units & Data type & Availabilty/condition \\
\hline \multicolumn{6}{|c|}{ Streamflow } \\
\hline basin_cfs & Streamflow leaving the basin through the stream network & one & $\mathrm{cfs}$ & double & always \\
\hline basin_cms & Streamflow leaving the basin through the stream network & one & $\mathrm{cms}$ & double & always \\
\hline basin_stflow_in & Basin area-weighted average lateral flow entering the stream network & one & inches & double & always \\
\hline basin_stflow_mo & Monthly area-weighted average simulated streamflow & one & inches & double & always \\
\hline basin_stflow_out & Basin area-weighted average streamflow leaving through the stream network & one & inches & double & always \\
\hline flow_out & Total flow out of model domain & one & $\mathrm{cfs}$ & double & always \\
\hline hru_outflow & Total flow leaving each HRU & nhru & $\mathrm{cfs}$ & real & always \\
\hline hru_streamflow_out & Total flow to stream network from each HRU & nhru & $\mathrm{cfs}$ & double & always \\
\hline obsq_inches & Measured streamflow at specified outlet station & one & inches & double & always \\
\hline obsq_inches_mo & Monthly measured streamflow at specified outlet station & one & inches & double & always \\
\hline runoff & Streamflow at each measurement station & nobs & runoff_units & real & nobs $>0$ \\
\hline seg_inflow & Total flow entering a segment & nsegment & $\mathrm{cfs}$ & real & nsegment $>0$ \\
\hline seg_lateral_inflow & Lateral inflow entering a segment & nsegment & $\mathrm{cfs}$ & real & nsegment $>0$ \\
\hline seg_outflow & Streamflow leaving a segment & nsegment & $\mathrm{cfs}$ & real & nsegment $>0$ \\
\hline seg_upstream_inflow & Sum of inflow from upstream segments & nsegment & $\mathrm{cfs}$ & real & nsegment $>0$ \\
\hline streamflow_cfs & Streamflow at each measurement station & nobs & $\mathrm{cfs}$ & real & nobs $>0$ \\
\hline streamflow_cms & Streamflow at each measurement station & nobs & $\mathrm{cms}$ & real & nobs $>0$ \\
\hline strm_farfield ${ }^{3}$ & Flow out of basin as farfield flow & one & $\mathrm{cfs}$ & double & $\begin{aligned} \text { cascade_flag } & =1 \text { and } \\
\text { ncascade } & >0\end{aligned}$ \\
\hline strm_seg_in $n^{3}$ & Streamflow as a result of cascading flow in each stream segment & nsegment & $\mathrm{cfs}$ & double & $\begin{aligned} \text { cascade_flag } & =1 \text { and } \\
\text { ncascade } & >0\end{aligned}$ \\
\hline$s u b \_c f s$ & Total streamflow leaving each subbasin & nsub & $\mathrm{cfs}$ & double & subbasin_flag $=1$ \\
\hline sub_cms & Total streamflow from each subbasin & nsub & $\mathrm{cms}$ & double & subbasin_flag $=1$ \\
\hline sub_inq & Sum of streamflow from upstream subbasins to each subbasin & nsub & $\mathrm{cfs}$ & double & subbasin_flag $=1$ \\
\hline \multicolumn{6}{|c|}{ Lake dynamics } \\
\hline basin_2ndstflow & Streamflow from second output point for lake HRUs using gate opening routing & one & inches & double & $\begin{array}{c}\text { strmflow_module }= \\
\text { strmflow_lake }\end{array}$ \\
\hline basin_lake_seep & Basin area-weighted average lake-bed seepage to GWRs & one & inches & double & $\begin{array}{l}\text { strmflow_module }= \\
\text { strmflow_lake }\end{array}$ \\
\hline basin_lake_stor & $\begin{array}{l}\text { Basin volume-weighted average storage for all lakes using broad-crested weir or } \\
\text { gate opening routing }\end{array}$ & one & inches & double & $\begin{array}{l}\text { strmflow_module }= \\
\text { strmflow_lake }\end{array}$ \\
\hline
\end{tabular}


Table 1-5. Input and output variables for the Precipitation-Runoff Modeling System, version 4 (PRMS-IV).-Continued

[HRU, hydrologic response unit; GWR, groundwater reservoir; CBH, climate-by-HRU; ET, evapotranspiration; cfs: cubic feet per second; cms: cubic meters per second; >, greater than; runoff_units, $0=$ cfs; $1=$ cms; precip_units, $0=$ inches; $1=$ millimeters; temp_units, $0=$ degrees Fahrenheit; $1=$ degrees Celsius; control parameters temp_module, precip_module, et_module, strmflow_module, model_mode, dprst_ flag, subbasin_flag, cascade_flag, and cascadegw_flag defined in table 1-2]

\begin{tabular}{|c|c|c|c|c|c|}
\hline Variable name & Description & Dimension $^{1}$ & Units & Data type & Availabilty/condition \\
\hline $\operatorname{din} 1$ & Inflow to each lake HRU using Puls or linear storage routing & nlake & $\mathrm{cfs}$ & real & $\begin{array}{c}\text { strmflow_module }= \\
\text { strmflow_lake }\end{array}$ \\
\hline gate_ht & Height of the gate opening at each dam with a gate & nratetbl & inches & real & $\begin{array}{c}\text { strmflow_module }= \\
\text { strmflow_lake and } \\
\text { nratetbl }>0\end{array}$ \\
\hline lake_2gw & Total seepage from each lake HRU & nlake & $\operatorname{cfs}$ & double & $\begin{array}{l}\text { strmflow_module }= \\
\text { strmflow_lake }\end{array}$ \\
\hline lake_elev & Elevation of each simulated lake surface & nlakeelev & feet & real & $\begin{array}{c}\text { strmflow_module } \\
=\text { strmflow_lake and } \\
\text { nlakeelev }>0\end{array}$ \\
\hline lake_inflow & Total inflow to each lake HRU & nlake & $\mathrm{cfs}$ & double & $\begin{array}{l}\text { strmflow_module }= \\
\text { strmflow_lake }\end{array}$ \\
\hline lake_interflow & Total interflow into each lake HRU & nlake & $\mathrm{cfs}$ & double & $\begin{array}{c}\text { strmflow_module }= \\
\text { strmflow_lake }\end{array}$ \\
\hline lake_invol & Inflow to each lake using broad-crested weir or gate opening routing & nlake & acre-feet & double & $\begin{array}{l}\text { strmflow_module }= \\
\text { strmflow_lake }\end{array}$ \\
\hline lake_lateral_inflow & Lateral inflow to each lake HRU & nlake & $\mathrm{cfs}$ & double & $\begin{array}{l}\text { strmflow_module }= \\
\text { strmflow_lake }\end{array}$ \\
\hline lake_outcfs & Streamflow leaving each lake HRU & nlake & $\mathrm{cfs}$ & double & $\begin{array}{l}\text { strmflow_module }= \\
\text { strmflow_lake }\end{array}$ \\
\hline lake_outcms & Streamflow leaving each lake HRU & nlake & $\mathrm{cms}$ & double & $\begin{array}{l}\text { strmflow_module }= \\
\text { strmflow_lake }\end{array}$ \\
\hline lake_outflow & Evaporation and seepage from each lake HRU & nlake & $\mathrm{cfs}$ & double & $\begin{array}{l}\text { strmflow_module }= \\
\text { strmflow_lake }\end{array}$ \\
\hline lake_outq2 & Streamflow from second outlet for each lake with a second outlet & nlake & $\mathrm{cfs}$ & double & $\begin{array}{l}\text { strmflow_module = } \\
\text { strmflow_lake }\end{array}$ \\
\hline lake_outvol & Outflow to each lake using broad-crested weir or gate opening routing & nlake & acre-feet & double & $\begin{array}{l}\text { strmflow_module }= \\
\text { strmflow_lake }\end{array}$ \\
\hline lake_precip & Total precipitation into each lake HRU & nlake & $\mathrm{cfs}$ & double & $\begin{array}{l}\text { strmflow_module = } \\
\text { strmflow_lake }\end{array}$ \\
\hline lake_seep_in & Total seepage into each lake HRU & nlake & $\mathrm{cfs}$ & double & $\begin{array}{l}\text { strmflow_module }= \\
\text { strmflow_lake }\end{array}$ \\
\hline lake_seepage & Lake-bed seepage from each lake HRU to the associated GWR & nlake & inches & real & $\begin{array}{l}\text { strmflow_module }= \\
\text { strmflow_lake }\end{array}$ \\
\hline
\end{tabular}


Table 1-5. Input and output variables for the Precipitation-Runoff Modeling System, version 4 (PRMS-IV).—Continued

[HRU, hydrologic response unit; GWR, groundwater reservoir; $C B H$, climate-by-HRU; ET, evapotranspiration; cfs: cubic feet per second; cms: cubic meters per second; $>$, greater than; runoff_units, $0=c f s$; $1=\mathrm{cms}$; precip_units, $0=$ inches; $1=$ millimeters; temp_units, $0=$ degrees Fahrenheit; $1=$ degrees Celsius; control parameters temp_module, precip_module, et_module, strmflow_module, model_mode, dprst_ flag, subbasin_flag, cascade flag, and cascadegw_flag defined in table 1-2]

\begin{tabular}{|c|c|c|c|c|c|}
\hline Variable name & Description & Dimension ${ }^{1}$ & Units & Data type & Availabilty/condition \\
\hline lake_sroff & Total surface runoff into each lake HRU & nlake & $\mathrm{cfs}$ & double & $\begin{array}{l}\text { strmflow_module }= \\
\text { strmflow_lake }\end{array}$ \\
\hline lake_sto & Storage in each lake HRU using Puls or linear storage routing & nlake & cfs-days & double & $\begin{array}{l}\text { strmflow_module }= \\
\text { strmflow_lake }\end{array}$ \\
\hline lake_stream_in & Total streamflow to each lake HRU & nlake & $\mathrm{cfs}$ & double & $\begin{array}{l}\text { strmflow_module }= \\
\text { strmflow_lake }\end{array}$ \\
\hline lake_vol & Storage for lake HRUs using broad-crested weir or gate opening routing & nlake & acre-feet & double & $\begin{array}{c}\text { strmflow_module = } \\
\text { strmflow_lake }\end{array}$ \\
\hline \multicolumn{6}{|c|}{ Water balance } \\
\hline basin_storage & Basin area-weighted average storage in all water-storage reservoirs & one & inches & double & always \\
\hline basin_storvol & Basin area-weighted average storage volume in all water-storage reservoirs & one & acre-inches & double & always \\
\hline subinc_deltastor & Change in storage for each subbasin & nsub & $\mathrm{cfs}$ & double & subbasin_flag $=1$ \\
\hline subinc_wb & Water balance for each subbasin & nsub & $\mathrm{cfs}$ & double & subbasin_flag $=1$ \\
\hline
\end{tabular}

${ }^{1}$ Dimension variables defined in table 1-1.

${ }^{2}$ Set by precipitation distribution module and can be modified by the interception module if all precipitation captured in canopy.

${ }^{3}$ Initially set by surface runoff module and can be modified by the soilzone module if Dunnian surface runoff occurs.

${ }^{4}$ Reflects availability of variables based on module selections. See variable description for the reason(s) a variable is conditional or always available. Variables unique to deprecated modules soltab_prms, temp_2sta_prms, ccsolrad_prms, ddsolrad_prms, potet_hamon_prms, smbal_prms, and ssflow_prms and not included in the table.

${ }^{5}$ Values are set to the last valid computed value; value is $<-99.0$ or $>150.0$ 


\section{Computation Control Module: call_modules}

The Computation Control Module (call_modules) defines the computational sequence and active PRMS-IV modules and sets simulation flags and dimensions. This module writes the list of the active modules to the user's screen. Input to the Computation Control Module is read from the Control File (table 1-2).

\section{Basin Module: basin}

The Basin Module (basin) declares and computes domain variables. This module is executed prior to the time-step loop of the simulation. The module checks for consistency in input parameters and computes and initializes domain internal variables, making them available to other PRMS-IV modules. Examples of internal variables computed by the Basin Module include the areas of each HRU that are pervious and impervious. Input parameters for the Basin Module are defined in table 1-3. The computed variables are defined in table 1-5.

\section{Cascade Module: cascade}

The Cascade Module (cascade) provides an optional cascading-flow procedure to route computed flows from upslope to downslope HRUs and groundwater reservoirs (GWRs). This procedure relies on specification of a directed, acyclic-flow network (Ford and Fulkerson, 1956); that is, a tree graph with no cycles that defines the flow paths within the domain. The Cascade Module allows for routing flows between spatial units that are delineated on the basis of changes in topography, land use, climate, soil properties, and geologic units to account for the changes in hydrologic response, timing, and drainage patterns as water moves from upslope to downslope portions of a watershed. Cascade Module routing is compatible with all non-deprecated PRMS-IV modules. Input parameters for the Cascade Module are defined in table 1-3. The computed variables are defined in table 1-5.

Each flow path is specified by starting at the highest upslope point and traversing downslope to terminate in a stream segment, lake HRU, or swale HRU without any circular flow. Different flow paths can be specified for surface water (HRU based) and groundwater (GWR based); however, groundwater-flow paths must terminate in a stream segment.

The cascading-flow procedure allows for complex paths, including flow routing to multiple downslope neighbors (that is, many-to-many, or divergent routing) or to one downslope neighbor (one-to-one routing). Figure 1-1 shows a routing pattern between 10 HRUs and 4 stream segments to illustrate how outflow can be routed from HRU to HRU and then to a stream network along various pathways. If HRUs are discretized solely on the basis of topography, the connectivity would be one-toone routing. However, if HRUs are discretized on the basis of other factors, such as elevation bands, a regular grid, or land-use patterns, then many-to-many routing can be used to route cascading flow on the basis of the fraction of area in the upslope HRU or GWR that contributes flow to each downslope HRU, GWR, or stream segment (fig. 1-2). An assumption of the cascade procedure is that flow is routed from/to contiguous HRUs, GWRs, and stream segments; however, users can specify any cascade link that is hydrologically valid.

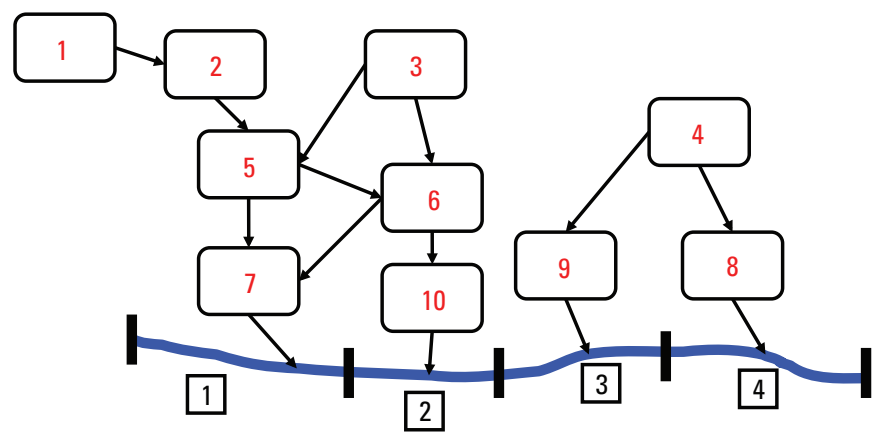

Figure 1-1. Example Hydrologic Response Unit (HRU) connectivity to a stream. HRUs are numbered 1 to 10 and stream segments 1 to 4 . 
$\boldsymbol{A}$

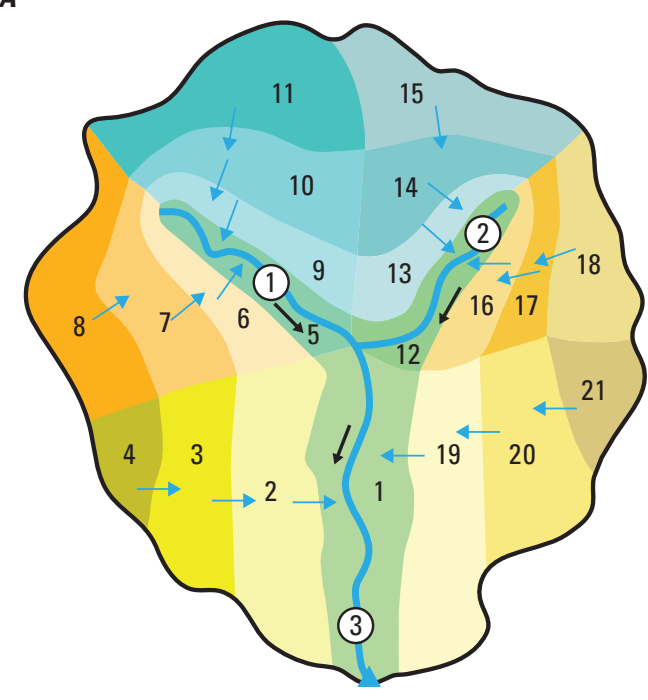

B

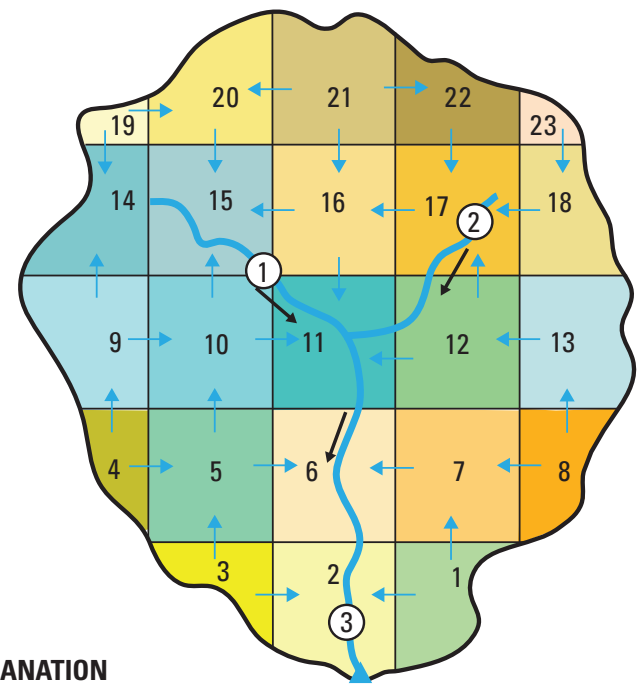

\section{EXPLANATION}

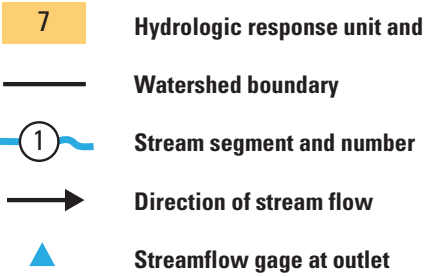

Figure 1-2. Cascading flow of surface runoff and interflow among hydrologic response units and stream segments. Cascading flow delineated from $A$, topology, climate, and vegetation; and $B$, a finite-difference grid (from Markstrom and others, 2008, fig. 18).

Surface water (HRU based) cascade routing is computed when the value of dimension parameter ncascade is specified greater than 0 in the Parameter File and the control parameter cascade_flag is specified equal to 1 (default value) in the Control File. Dimension ncascade is the total number of links from HRUs to HRUs, including lake and swale HRUs, and from HRUs to stream segments in the domain. Parameter cascade_flag allows users to include cascade parameters in the Parameter File and turn-off cascade computations (value specified equal to 0 ). Groundwater (GWR based) cascade routing is computed when dimension parameter ncascdgw and control parameter cascadegw_flag are set similarly. Dimension ncascdgw is the total number of links from GWRs to GWRs and from GWRs to stream segments in the domain.

Cascading flow computations are performed from the top of each flow path to the terminus, maintaining continuity. To simplify specification of the flow path connectivity parameters, the Cascade Module determines a routing order to ensure that computations for an HRU, GWR, or stream segment are not performed prior to any that can contribute flow to it from any other flow path. In addition, the Cascade Module can check for circular flow paths. If circular paths are found, an error message is printed to the screen indicating that the connectivity parameters must be corrected before the simulation can continue. The parameter circle_switch is used to turn on (1) and off ( 0 ) the checking for circular paths. Users should set circle_switch to 1 until the code has verified that circles are not present in the connectivity parameters. Once all circles are resolved, it is recommended that circle_switch be set to 0 to reduce execution time.

Four parameters specify each HRU-to-HRU and HRU-to-stream segment cascade link, hru_up_id, hru_down_id, hru_strmseg_down_id, and hru_pct_up. For any HRU cascade link, if the parameter hru_strmseg_down_id is specified with a value greater than 0 , this value overrides the value of hru_down_id, and all flow for the cascade link goes to the stream segment identified by hru_strmseg_down_id. In this case, if flow from the upstream HRU to the downstream HRU is desired, an additional cascade link must be specified with the value of hru_strmseg_down_id equal to 0 .

Similarly, the connectivity pattern of GWR-to-GWR and GWR-to-stream segment cascade links is defined by four parameters, gw_up_id, gw_down_id, gw_strmseg_down_id, and gw_pct_up, each dimensioned by ncascdgw. For any GWR cascade link, if the parameter gw_strmseg_down_id is specified with a value greater than 0 , this value overrides the value of gw_down_id, and all flow for the cascade link goes to the stream segment gw_strmseg_down_id. In this case, if flow from the upstream GWR to the downstream GWR is desired, an additional cascade link must be specified with the value of 
gw_strmseg_down_id equal to 0 . Generally, the GWR cascade links are set equal to the HRU cascade links unless there are swale HRUs or additional information is available to define the GWR connectivity pattern.

An HRU that is not specified in any cascade link is a swale HRU. The associated value of parameter hru_type is specified as 3 for all swale HRUs. Stream segments not included in any HRU or GWR cascade link do not receive lateral inflow (surface runoff, interflow, or groundwater flow). The GWR connectivity parameters must account for all GWRs. Likewise, when stream network connectivity parameters are specified; all stream segments and lake HRUs must be included.

The parameters hru_pet_up and gw_pet_up assign the decimal fraction of total flow from an upslope HRU or GWR that is routed by each cascade link, respectively. If the sum of hru_pet_up or gw_pet_up decimal fractions of all cascade links for an upslope HRU or GWR is less than 1.0, the remainder is apportioned evenly among all cascade links originating from that upslope HRU or GWR.

Additionally, two scalar parameters are used to simplify cascade links. The Cascade Module ignores any cascade link with an upslope HRU or GWR area less than the minimum of cascade_tol and 7.5 percent of the area of the upslope HRU or GWR. Cascade links with less than this minimum value are ignored and the remainder is apportioned evenly among all cascade links originating from the HRU or GWR.

One-to-one cascade routing can be forced when the parameter cascade_flg is set to a value of 1 , even though a many-tomany cascade pattern is specified. The cascade link with the largest fraction (hru_pet_up or gw_pet_up) of cascading flow of all links originating from the HRU or GWR is set to a value of 1.0 and the other links are ignored.

Connectivity parameters and dimension parameters can be derived by using a geographic information system (GIS) analysis of a Digital Elevation Model (DEM; U.S. Geological Survey, 2000) on the basis of flow accumulation and flow direction, the HRU map, and the delineated stream network. This can result in zero, one, or multiple cascade links for each HRU. The number of cascade links, in general, is a function of the complexity of the HRU delineation. The fraction of an HRU that cascades to a neighbor is the contributing area for all DEM cells that have a flow direction to the neighboring HRU or stream segment divided by the total area of the HRU.

Generally, an HRU will have at least one cascade. An HRU without cascades would occur if an HRU were delineated as a closed basin or swale. In some cases, GIS processing might incorrectly indicate an HRU to be a swale, for example, a wetland that outflows to a stream only under wet conditions. It is recommended that any HRU without a cascade be verified as such. Determination of cascade links for very complex HRU delineations can result in some HRUs cascading to each other or multiple HRU circular flow paths. Circles should be corrected by removing cascade links during the GIS processing.

Connectivity parameters for HRUs delineated as a regular grid, such as a finite-difference grid, can be approximated from their average land-surface elevations. The relative differences in land-surface elevations between an HRU and coincident HRU neighbors or stream segment can be used to approximate the fraction of an HRU that contributes flow to its downstream neighbor (Henson and others, 2013). In general, finer grids result in better approximations of flow accumulation and direction within each grid cell. Use of this method can simplify the determination of flow path and minimize the number of circles.

The module checks the connectivity parameters and prints messages when problems are found. Error messages are printed for HRU flow paths when: (1) a circular path is detected and (2) any value for input parameters hru_up_id or hru_down_id is specified greater than dimension parameter nhru. Error messages are printed for GWR flow paths when: (1) a circular path is detected, (2) any value for input parameters $\mathbf{g w}$ _up_id or $\mathbf{g w}$ _down_id is specified greater than dimension parameter ngw, and (3) any GWR does not cascade or receive flow.

Warning messages, the cascade flow paths and routing order are printed to the file "cascade.msgs" when the control parameter print_debug is specified with the value 13. This file can be used to verify that the cascade flow paths are consistent with the topography, drainage patterns, and HRU delineation.

The Cascade Module computes variables that are used by other modules (srunoff_smidx, srunoff_carea, soilzone, and gwflow described in this appendix) to route the surface-water and groundwater flows computed in those modules from upslope to downslope HRUs, GWRs, and stream segments. Cascading surface water is added to downslope HRUs as infiltration to the capillary reservoir or lateral inflow to stream segments. Cascading groundwater flows are added to downslope GWRs as gravity drainage or lateral inflow to stream segments.

\section{Solar Table Module: soltab}

Tables consisting of daily estimates of the potential (clear sky) short-wave solar radiation (soltab_potsw) for each HRU are computed on the basis of hours between sunrise and sunset (sotab_sunhrs) for each day of year for each HRU in module soltab. The potential short-wave solar radiation is also computed for each day of the year for a horizontal plane at the surface of the centroid of the domain. Input parameters are used to compute the solar-table variables and are defined in table 1-3. Equation symbols used in this section that correspond directly to PRMS-IV input or output are defined in this table. 
Daily estimates of obliquity are computed from (Meeus, 1999):

$$
E=\mathbf{1}-[\mathbf{E C} \times \cos (j d-\mathbf{3}) \times \mathbf{r a d}]
$$

where

$E \quad$ is the obliquity of the Sun's ecliptic, angular degrees;

EC is the eccentricity of the earth's orbit (approximately 0.01671), radians;

$j d \quad$ is the day of year number (3 is subtracted from the day number because the solar day of year begins on

December 29), days; and

$\mathrm{rad} \quad$ is the revolution speed of the earth (approximately 0.0172), radians per day.

Daily estimates of solar declination are computed from (Meeus, 1999):

$$
\begin{aligned}
D M= & 0.006918-0.399912 \times \cos \left(E_{r t}\right)+0.070257 \times \sin \left(E_{r t}\right)-0.006758 \times \cos \left(E_{r t}\right) \\
& +0.000907 \times \sin \left(2 * E_{r t}\right)-0.002697 \times \cos \left(3 \times E_{r t}\right)+0.00148 \times \sin \left(3 \times E_{r t}\right),
\end{aligned}
$$

where

$D M \quad$ is the solar declination, angular degrees; and $E_{r t}=\mathbf{r a d} \times(j d-\mathbf{1})$.

Daily estimates of potential solar radiation and daylight hours are computed by using values of $E$ and $D M$, and estimates of slope, aspect, and latitude values, using a combination of methods described in Frank and Lee (1966) and Swift (1976). Daylight length is computed in radians, converted to hours, and multiplied by the hourly solar constant. The hour angles at time of sunrise $(s r)$ and sunset (ss) as well as length of daylight (soltab_sunhrs) for each HRU for each day of the year are computed by:

$$
\begin{gathered}
s r_{H R U}=\cos ^{-1}\left[-\tan \left(\mathbf{h r u} \mathbf{l a t}_{H R U}\right) \times \tan \left(D M_{H R U}\right)\right], \\
s s_{H R U}=-1 \times s r_{H R U} \text { and } \\
\text { soltab_sunhrs } s_{H R U}=\mathbf{1 2} \times\left(s s_{H R U}-s r_{H R U}\right),
\end{gathered}
$$

where

ssHRU is the hour angle of sunset on the HRU measured from solar noon; morning values are negative and evening values are positive, radians; and

srHRU is the hour angle of sunrise on the HRU measured from solar noon; morning values are negative and evening values are positive, radians.

Potential solar radiation for each day of the year is calculated according to:

$$
\text { soltab_potsw } w_{H R U}=\mathbf{S C} \times\left(\mathbf{c 1}_{P S R}+\mathbf{c} \mathbf{2}_{P S R}\right),
$$

where SC is the solar constant (458.4 calories per square centimeter per radian is suggested by Frank and Lee [1966]),

$$
\begin{aligned}
& \mathbf{c 1}_{P S R}=\frac{\sin \left(D M_{H R U}\right) \times \sin \left(\mathbf{h r u}_{-} \mathbf{l a t}_{H R U}\right) \times\left(s s_{H R U}-s r_{H R U}\right) \times 24}{\mathbf{2} \times \pi} \quad ; \text { and } \\
& \mathbf{c 2}_{P S R}=\frac{\cos \left(D M_{H R U}\right) \times \cos \left(\mathbf{h r u} \mathbf{l a t}_{H R U}\right) \times\left[\sin \left(s s_{H R U}\right)-\sin \left(s r_{H R U}\right)\right] \times 24}{2 \times \pi} .
\end{aligned}
$$

Potential solar radiation for each day of the year for the basin (soltab_basinpotsw) is also computed by using equations 1-6-1-8, except the latitude and sunrise and sunset times of the basin centroid are used. 


\section{Time-Series Data Module: obs}

The Time-Series Data Module (obs) reads the time-series variables from the Data File (see Appendix 2 for a description of the Data File format), making them available for input to other modules and output to the Statistics Variable and Animation Files.

Meteorological measurements of precipitation (precip), air temperature (tmax and tmin), pan evaporation (pan_evap), and potential solar radiation (solrad) are distributed to each HRU by the other modules. If solrad is not specified in the Data File, a value is estimated for each day of the year for each HRU (soltab_potsw) by the Solar Table module (soltab).

The types of meteorological data that are input to PRMS-IV depend on the modules selected for a particular simulation. For all Temperature-and Precipitation-Distribution Modules, except for module climate $\mathrm{hru}$, precipitation (precip) and maximum and minimum air temperature (tmax and tmin, respectively) for at least one climate station must be included in the Data File. The climate_hru module reads pre-processed values of hru_ppt, tmaxf, and tminf, and, optionally, potential evapotranspiration (potet) and solar radiation ( swrad) for each HRU. Consequently, when using this module, Data File values of precip, tmax, tmin, pan_evap, and solrad are optional.

Measured data for streamflow (runoff) and depth of snowpack (snow) can be included in the Data File for comparison to simulated values of streamflow (basin_cfs, seg_outflow, and sub_cfs) and snowpack ( $p k \_d e p t h$ ), respectively. Measured values of gate-height openings at the outflow of lakes can be input for simulation of outflow from lakes, and the elevation of the surface of lakes (lake_elev) can be used to compare simulated lake-surface elevations (elevlake) when the strmflow_lake module is selected.

The units of all precipitation and air-temperature data specified in the Data File must be defined. Precipitation units (precip_units: 0 for inches, 1 for millimeters) and temperature units (parameter temp_units: 0 for Fahrenheit, 1 for Celsius) are specified in the Parameter File. The units of all parameters based on temperature and precipitation must be consistent with these definitions. Input parameters and variables for module obs are defined in table 1-3 and table 1-5, respectively.

\section{Temperature-Distribution Modules}

Air temperature is used in computations of evaporation, transpiration, sublimation, and snowmelt for each HRU. Temperature-Distribution Modules compute and distribute maximum, minimum, and average air temperatures in degrees Celsius and Fahrenheit for each HRU for each time step. The four Temperature-Distribution Modules included in PRMS-IV are temp_1sta, temp_2sta_prms (deprecated), temp_laps, and temp_dist2. Module temp_2sta_prms is only retained for backward compatibility with older PRMS applications and is documented by Leavesley and others (1996). Input parameters and input and output variables for modules temp_1sta, temp_laps, and temp_dist2 are defined in tables 1-3 and $1-5$, respectively.

The modules xyz_dist and ide_dist provide two additional temperature-distribution algorithms (see the "Combined Climate Distribution Modules" section in this appendix). The seventh option is to input temperature values that have been predistributed to each HRU and input using the climate hru module that is described in the "Climate-by-HRU Distribution Module" section in this appendix. The user sets the control parameter temp_module specified in the Control File to one of the seven temperature distribution module names. The best option selection depends on the climate-distribution method that best represents the watershed and the number and locations of air-temperature measurement stations available.

The elevation of each air-temperature measurement station can be specified in either feet or meters (set parameter elev units to 0 for feet and 1 for meters). Monthly lapse-rate coefficients must be expressed in units that are consistent with the specified temperature and elevation units.

In each of the modules, the HRU adjusted average temperature for each time step (tavgf), and the basin-area weighted maximum, minimum, and average temperatures (basin_tmax, basin_tmin, and basin_temp) for the time step are computed as follows:

$$
\begin{aligned}
\operatorname{tavg} f_{H R U} & =\frac{\operatorname{tmax} f_{H R U}+t \min f_{H R U}}{2}, \\
\text { basin_tmax } & =\frac{\sum_{i=1}^{n h r u}\left(\operatorname{tmaxf}_{i} \times \text { hru_area }_{i}\right)}{\text { basin_area }},
\end{aligned}
$$




$$
\begin{aligned}
\text { basin_t } t \min =\frac{\sum_{i=1}^{n h r u}\left(t \min f_{i} \times \mathbf{h r u} \_ \text {area }_{i}\right)}{\text { basin_area }} \text {, and } \\
\text { basin_temp }=\frac{\sum_{i=1}^{n h r u}\left(t e m p f_{i} \times \mathbf{h r u} \text { _area } i\right)}{\text { basin_area }},
\end{aligned}
$$

Variable names shown in the equations 1-9-1-12 are for degrees Fahrenheit. Comparable variables in degrees Celsius also are calculated. The output units for variables basin tmax, basin tmin, and basin temp depend on parameter temp units.

Any measured temperature values (tmin or tmax) less than -99 or greater than 150 are considered anomalous and ignored by Temperature-Distribution Modules. Modules have methods for dealing with limited missing data. For modules temp_1sta and temp_laps, consecutive missing values, up to the value of parameter max_missing, are set to the previous valid value. If more than max_missing values are encountered, an error message is printed and the simulation stops. For modules ide_dist and temp_dist2, missing temperature values are ignored. However, if values are missing for all air-temperature measurement stations for any time step, an error message is printed and the simulation stops. It is recommended that data gaps for meteorological data be corrected and quality assessments be made of these data prior to execution of PRMS-IV.

\section{temp_1sta}

Module temp_1sta distributes air temperature to each HRU based on a measured value of maximum (tmax) and minimum (tmin) temperature. This module distributes temperatures to each HRU by using monthly lapse-rate parameters (tmax lapse and tmin_lapse) and temperature-adjustment parameters (tmax_adj and tmin_adj). The lapse rates represent the change in temperature with 1,000 units of elevation change. This module is used when temperature data from one or more measurement stations are available and the measured data can be applied to each HRU by the parameter hru_tsta. The subscript $t$ sta is the measurement station associated with the HRU by parameter hru_tsta. The maximum and minimum air temperatures are computed for each HRU according to:

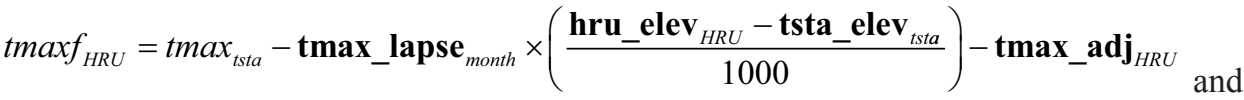

$$
\begin{aligned}
& \text { potet }_{H R U}=\text { epan_coef } f_{\text {month }} \times \text { pan_evap } \text { hru_pansta, }_{\text {, }}
\end{aligned}
$$

where

tsta is the measurement station identification number associated with the HRU by parameter hru_tsta.

\section{temp_laps}

Module temp_laps can be used when data from at least two measurement stations at different elevations are available to compute and distribute air temperature. Each HRU is assigned air temperatures on the basis of daily computed lapse rates during each time step in the simulation from a pair of available measurement stations. The station that is most representative of the temperature at the HRU is designated as the base station and specified by parameter hru_tsta (identified by subscript $t$ sta). The station that is not the base station is called the lapse station and specified by parameter hru_tlaps (identified by subscript tlaps) and is used with the base station to calculate the lapse rate. Maximum and minimum HRU temperatures are computed for each time step by a temperature lapse rate from the two associated stations according to:

$$
t \max f_{H R U}=\operatorname{tmax}_{t s t a}+\left(\operatorname{tmax}_{\text {tlaps }}-\text { tmax }_{\text {tsta }}\right) \times \text { elfac }{ }_{H R U}-\mathbf{t m a x} \_\mathbf{a d \mathbf { j } _ { H R U }} \text { and }
$$




$$
t \min f_{H R U}=\operatorname{tmin}_{\text {tsta }}+\left(\operatorname{tmin}_{\text {tlaps }}-\operatorname{tmin}_{\text {tsta }}\right) \times e l f a c_{\text {HRU }}-\mathbf{t m i n} \_\mathbf{a d j}_{H R U},
$$

where

$$
e l f a c_{H R U}=\left(\frac{\text { hru_elev }_{H R U}-\text { tsta_elev }_{\text {tsta }}}{\text { tsta_elev }_{\text {tlaps }}-\text { tsta_elev }_{\text {tsta }}}\right),
$$

\section{temp_dist2}

Module temp_dist2 distributes temperatures to the HRUs by computing weights based on lapse rates and the inverse of the square of the distance between the centroid of the HRU and the location of multiple air temperature measurement stations (Dean and Snyder, 1977; Bauer and Vaccaro, 1987; Vaccaro, 2007), according to:

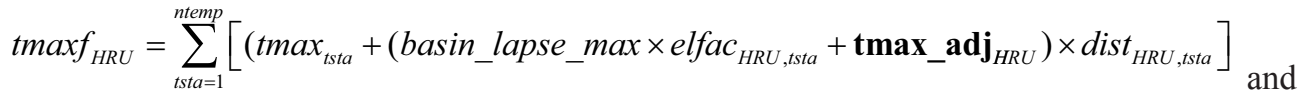

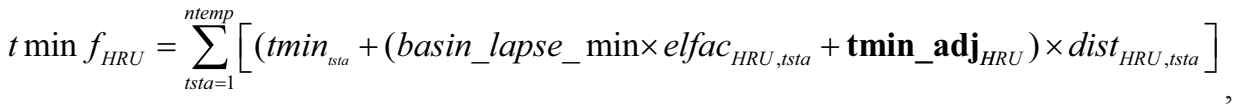

where

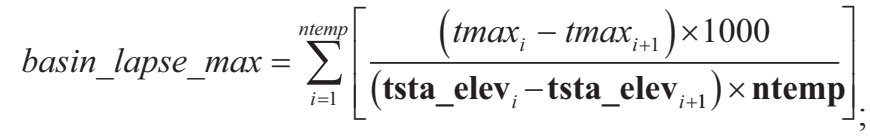

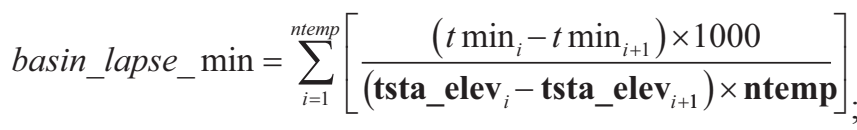

$$
\begin{aligned}
& e^{e l f a c_{H R U, t s t a}}=\frac{\text { hru_elev }_{H R U}-\text { tsta_elev }_{\text {tsta }}}{1000} \text {; and } \\
& \operatorname{dist}_{H R U, t s t a}=\left(\frac{1}{\sqrt{\left(\mathbf{h r u} \_\mathbf{x l a t}_{H R U}-\text { tsta_ylat }_{t s t a}\right)^{2}+\left(\mathbf{h r u}_{\mathbf{n}} \mathbf{x l o n g}_{H R U}-\text { tsta_xlong }_{t s t a}\right)^{2}}}\right)^{2} .
\end{aligned}
$$

The summation terms on the right-hand side of equations 1-20 and 1-21 are limited by monthly lapse-rate parameters lapsemin_min, lapsemin_max, lapsemax_max, and lapsemax_min. The number of measurement stations can be a subset of the available stations (dimension ntemp) based on the value of parameter dist_max that sets the maximum distance between a measurement station location and the HRU centroid for inclusion. 


\section{Precipitation-Distribution Modules}

Precipitation-Distribution Modules determine the form (rain, snow, or mixed) of, and distribute precipitation for, each HRU for each time step. Measured precipitation can be input in units of inches or millimeters (parameter precip_units: 0 for inches, 1 for millimeters). Results are in units of inches. The three Precipitation-Distribution Modules included in PRMS-IV are precip_1sta, precip_laps, and precip_dist2. The modules xyz_dist and ide_dist provide two additional precipitation-distribution algorithms (see the "Combined Climate Distribution Modules" section in this appendix). The sixth option is to input precipitation values that have been pre-distributed to each HRU and input using the climate_hru module that is described in the "Climate-by-HRU Distribution Module" section in this appendix. The user sets the control parameter precip_module specified in the Control File to one of the six precipitation distribution module names. The best option selection depends on the climate-distribution method that best represents the watershed and the number and locations of precipitation measurement stations available (dimension nrain). Input parameters and input and output variables for these modules are defined in tables 1-3 and 1-5, respectively.

The form of the precipitation (rain, snow, or a mixture of both) is important to the simulation of snow accumulation, snowmelt, infiltration, and runoff. Precipitation form on each day is estimated from the HRU maximum and minimum daily air temperatures and their relation to the temperature when precipitation is all snow (parameter tmax_allsnow) and the temperature when precipitation is all rain (parameter tmax_allrain) for the current month. Precipitation is all snow on an HRU when the maximum daily air temperature is less than or equal to tmax_allsnow. Precipitation is all rain when the minimum air temperature is greater than tmax_allsnow and when the maximum air temperature is greater than or equal to the tmax_allrain value of the current month.

When the maximum daily air temperature is between tmax_allsnow and tmax_allrain; and the minimum daily air temperature is less than or equal to tmax_allsnow, HRU precipitation is simulated as a mixture of rain and snow. The fraction of the total precipitation occurring as rain at each HRU is computed by:

$$
\operatorname{prmx}_{H R U}=\left(\frac{t \max f_{H R U}-\mathbf{t m a x} \_ \text {allsnow }}{\operatorname{tmaxf} f_{H R U}-t \operatorname{tminf} f_{H R U}}\right) \times \mathbf{a d j m i x} \_ \text {rain }_{\text {month }} .
$$

If the value of prmx for an HRU is greater than or equal to 1.0, the precipitation is considered to be all rain.

In each of the modules, daily precipitation, rain, and snow (basin_ppt, basin_rain, and basin_snow) for the basin are calculated as follows:

$$
\begin{aligned}
& \text { basin_ppt }=\frac{\sum_{i=1}^{\text {nhru }}\left(h r u_{-} p p t_{i} \times \mathbf{h r u} \_\mathbf{a r e a}_{i}\right)}{\text { basin_area }} \text {, } \\
& \text { basin_rain }=\frac{\sum_{i=1}^{\text {nhru }}\left(h r u \_r a i n_{i} \times \mathbf{h r u}_{-} \mathbf{a r e a}_{i}\right)}{\text { basin_area }} \text {, and } \\
& \text { basin_snow }=\frac{\sum_{i=1}^{n h r u}\left(h r u \_s n o w_{i} \times \mathbf{h r u} \_ \text {area }_{i}\right)}{\text { basin_area }} .
\end{aligned}
$$

\section{precip_1sta}

Module precip_1sta was named precip_prms in all previous versions of PRMS. This module distributes measured precipitation to each HRU for each time step on the basis of a measured value of precipitation and parameters that adjust the amount of mixed precipitation (equation 1-24), the amount of rain (rain_adj) and the amount snow (snow_adj). These parameters are used to account for elevation, spatial variation, topography, gage location, and deficiencies in gage catch. This module 
is used when precipitation data from one or more measurement stations are available and the measured data can be applied to each HRU by the parameter hru_psta. If the form of the precipitation (equation 1-24) is all rain, then the precipitation at each HRU is computed as:

$$
h r u_{-} p p t_{H R U}=\text { precip }_{p s t a} \times \mathbf{r a i n} \_\mathbf{a d j}_{H R U, \text { month }},
$$

where

psta is the measurement station associated with the HRU by parameter hru_psta.

If the form of the precipitation is all snow, or a mixed precipitation event, then the precipitation at each HRU is computed as:

$$
h r u \_p p t_{H R U}=\text { precip } p_{p s t a} \times \mathbf{s n o w} \_\mathbf{a d j}_{H R U, \text { month }} .
$$

\section{precip_laps}

Module precip_laps can be used when data from at least two measurement stations at different elevations are available to compute and distribute precipitation. Each HRU is assigned precipitation on the basis of daily computed lapse rates during each time step in the simulation from a pair of available measurement stations. The station that is most representative of the precipitation at the HRU is designated as the base station and specified by parameter hru_psta (identified by subscript $p s t a$ ). The station that is not the base station is called the lapse station and specified by parameter hru_plaps (identified by subscript plaps) and is used with the base station to calculate the lapse rate. HRU precipitation is computed for each time step by a lapse rate from the two associated stations. If the form of the precipitation (equation 24) is all rain, then precipitation at each HRU is computed as:

$$
\begin{aligned}
& h r u_{-} p t_{H R U}=\text { precip }_{p s t a} \times
\end{aligned}
$$

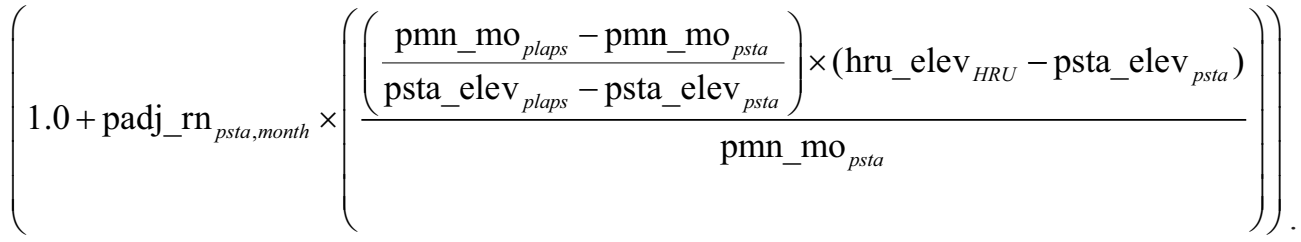

If the form of the precipitation is all snow, or contains any fraction of snow, then precipitation at each HRU is computed as:

$$
\begin{aligned}
& h r u_{-} p_{\text {HRU }}=\text { precip }_{p s t a} \times
\end{aligned}
$$

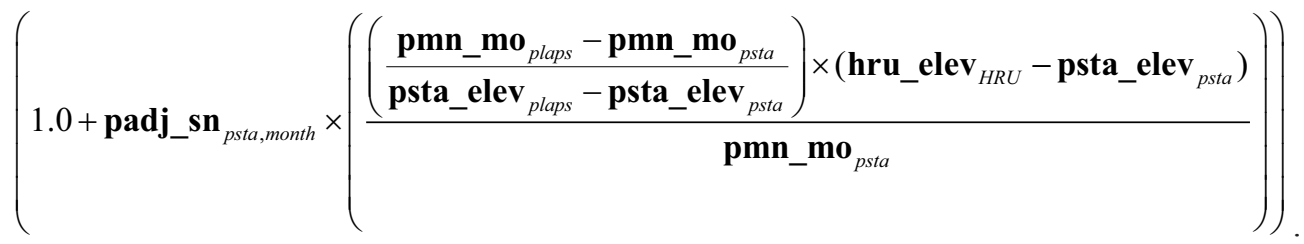

\section{precip_dist2}

Module precip_dist2 distributes precipitation to the HRUs by computing weights based on lapse rates and the inverse of the square of the distance between the centroid of the HRU and the location of multiple precipitation measurement stations (Dean and Snyder, 1977; Bauer and Vaccaro, 1987; Vaccaro, 2007), according to: 


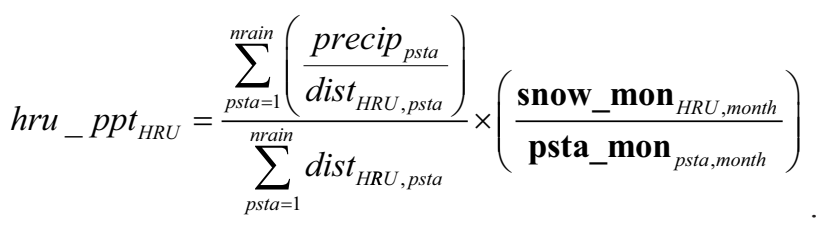

If the form of the precipitation is all snow, or contains any fraction of snow, then precipitation at each HRU is computed as:

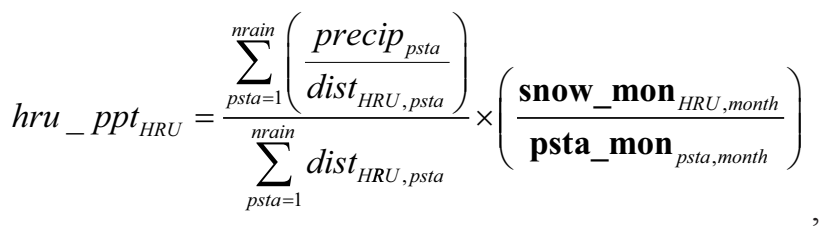

where

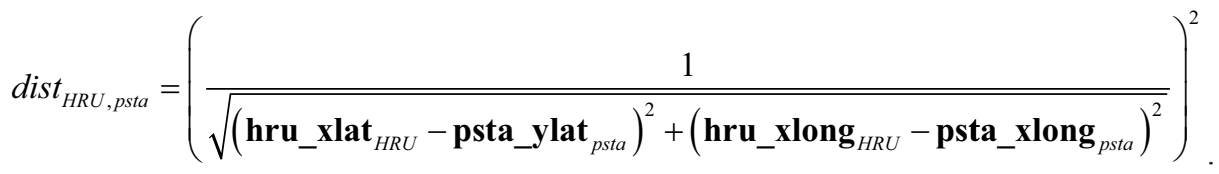

The value of dist is limited by parameter maxday_prec. The number of measurement stations can be a subset of the available stations (dimension nrain) based on the value of parameter dist_max that sets the maximum distance between a measurement station location and the HRU centroid for inclusion.

\section{Combined Climate-Distribution Modules}

The ide_dist and $x y z$ _ist modules distribute maximum and minimum temperatures and precipitation to each HRU. When either of these modules is selected for the Temperature-Distribution Module, it also must be selected for the Precipitation-Distribution Module. The general guidelines outlined at the beginning of the Temperature-Distribution Modules and Precipitation-Distribution Modules sections apply to these modules as well.

\section{xyz_dist}

Module xyz_dist uses a three-dimensional, multiple-linear regression based on longitude, latitude, and elevation to distribute temperature and precipitation data from two or more measurement stations or from results at grid cells of atmospheric models (Hay and others, 2000; Hay and Clark, 2003). The methodology was initially developed to distribute statistically downscaled precipitation and temperature from an atmospheric model (a single grid point) to each HRU in a watershed (Hay and others, 2000). Further testing found module xyz dist to be appropriate for distributing station data as well (Hay and McCabe, 2002; Hay and others, 2002; Hay and others, 2006a; 2006b; 2006c). Table 1-3 and table 1-5 list the input parameters and variables, respectively, for module xyz dist.

Multiple linear-regression relations are developed for each dependent climate variable (precipitation and maximum and minimum air temperature) by using station or grid cell latitude $(y)$, longitude $(x)$, and elevation $(z)$ as the multiple linear regression independent variables (Hay and others, 2000, 2002). Multiple linear-regression parameters (ppt_lapse for precipitation and max_lapse, and min_lapse for maximum and minimum air temperature, respectively) for the three independent variables in the equation $(x, y$, and $z)$ are computed for each month by using monthly mean values from the climate stations located in or near the watershed. The general equation below describes a plane in three-dimensional space with multiple linear-regression parameters or "slopes" (lapse) intersecting the climate variable $(\mathrm{CV})$ axis at $b 0$.

$$
C V=\left(\text { lapse }_{x} \times x_{s t a}\right)+\left(\text { lapse }_{y} \times y_{s t a}\right)+\left(\text { lapse }_{z} \times z_{s t a}\right)+b_{0},
$$


where
lapsex, laspse $y$, and lapse $z$ are the appropriate values of ppt_lapsedirection,month, max_lapsedirection,month, and min_lapsedirection,month depending on which climate variable is being computed.

The climate variable precipitation $\left(h r u \_p t\right)$ is selected to illustrate how equation 1-35 is used. The procedure is identical for calculation of maximum and minimum temperature (tmaxf and tminf). First, mean daily precipitation (ppt_mean) and corresponding mean location ( $x_{-}$mean, $y_{-}$mean, and $z_{-}$mean) are calculated from a set of stations specified by the parameter psta nuse. Any station that does not have a valid value for a time step is not included in this calculation. Consequently, a different set of stations can be used each day. If none of the stations have valid values on a particular day, then the mean monthly value is used (parameter psta_month_ppt). With these values, $b 0$ is computed according to:

$$
\begin{aligned}
b_{0}= & p p t \_m e a n-\left(\mathbf{p p t} \_ \text {lapse }_{x, \text { month }} \times x_{-} \text {mean }\right)-\left(\mathbf{p p t} \_ \text {lapse }_{y, \text { month }} \times y_{-} \text {mean }\right) \\
& -\left(\mathbf{p p t} \text { lapse } \mathbf{e}_{z, \text { month }} \times z_{-} \text {mean }\right)
\end{aligned}
$$

Then, the precipitation amount for each HRU can be computed according to:

$$
\begin{aligned}
h r u \_p p t_{H R U} & =\left(\mathbf{p p t} \_ \text {lapse } e_{x, \text { month }} \times \mathbf{h r u} \mathbf{x}_{H R U}\right)+\left(\mathbf{p p t} \_ \text {lapse } \mathbf{e}_{x, \text { month }} \times \mathbf{h r u} \_\mathbf{y}_{H R U}\right) \\
& +\left(\mathbf{p p t} \_ \text {lapse } \mathbf{x}_{x, \text { month }} \times \mathbf{h r u} \mathbf{z}_{H R U}\right)+b_{0}
\end{aligned}
$$

All dependent and independent variables used in the regression (equations 1-36 and 1-37) are transformed by subtracting the mean (parameters ppt_add, $\mathbf{x} \_$add, $\mathbf{y} \_$add, and $\mathbf{z} \_$add) and dividing by the standard deviation (parameters ppt_div, $\mathbf{x} \_$div, y_div, and $\mathbf{z} \_$div) to remove the effects of units, magnitude, and inconsistency in specification of the origin. The multiple linearregression parameter (ppt_lapse) must be determined by using these normalized values.

A common problem with this approach is that precipitation amounts tend to increase as the elevation of the HRUs increase. This means that at the higher elevations, there may always be precipitation simulated whether any precipitation is measured at the stations or not. To address this problem, the parameter psta_freq_nuse is specified to indicate a set of stations used to determine if there actually is precipitation in the watershed. The value of the parameter rain_code determines how this information will be used (table 1-3).

\section{ide_dist}

Module ide_dist can be used when data from three or more measurement stations are available to compute and distribute precipitation and temperature. The module uses a combination of Inverse Distance and Elevation (IDE) weighting for interpolating maximum and minimum temperature-station data to each HRU. The IDE methodology was developed for use when there is adequate station coverage in the domain. If there is a significant portion of the domain with no measured station data, then an alternative module may be more appropriate. Tables 1-3 and 1-5 define the input parameters and input and output variables, respectively, for module ide_dist.

Module ide dist determines the closest two climate-stations with elevations above and below a given HRU's elevation, and linearly interpolates climate values (precip_elev, tmax_elev, and tmin_elev) for the HRU on the basis of the data from these two stations. This interpolation is done in the vertical direction only. The station data are sorted by elevation and a three-station moving average is computed for each of the two bounding stations. If the HRU elevation is not within the range of climate station elevations, then the lowest and highest three-station mean for the watershed is used to estimate the climate values. The set of stations used in a simulation are specified by using the psta_nuse and tsta_nuse parameters.

Stations having values outside of two standard deviations from the mean for a time step are not included in the computation. If three or fewer stations have valid values, the climate values will be calculated from the station mean monthly values (parameters psta_month_ppt for precipitation and tsta_month_max and tsta_month_min for maximum and minimum air temperature, respectively). To avoid unrealistic temperature values, the slope will not exceed the dry adiabatic lapse rate (constant decrease of $2.4^{\circ} \mathrm{C}$ per 1,000 meters gained) when extrapolating.

The climate values distance exponent (dist_exp) is determined by computing a weight, relating each HRU to each station (identified by subscript $s t a$ ) according to:

$$
w_{H R U, s t a}=\left(\frac{1.0}{d_{H R U, s t a}}\right)^{\text {dist } \_x p}
$$


where

wHRU,sta is the weight factor relating an HRU to a station; and

dHRU,sta is the distance between an HRU and a station.

Weight factors are computed for precipitation stations and for air temperature stations. Increasing the value of parameter dist_ exp increases the influence of stations that are farther away from the HRU. After the weights are calculated, the distance-based component of precipitation and maximum and minimum air temperature values (precip_dist, tmax_dist, and tmin_dist) for each HRU are computed as:

$$
\begin{aligned}
& \text { precip_dist }_{H R U}=\sum_{\text {sta }=1}^{\text {rain nsta }}\left(w_{H R U, s t a} \times \text { precip }_{\text {sta }}\right), \\
& \text { tmax_dist } t_{H R U}=\sum_{\text {sta }=1}^{\text {tempnnsta }}\left(w_{H R U, s t a} \times \text { tmax }_{\text {sta }}\right) \text {, and } \\
& \text { tmin_dist } t_{H R U}=\sum_{\text {sta }=1}^{\text {temp_nsta }}\left(w_{H R U, s t a} \times \text { tmin }_{\text {sta }}\right),
\end{aligned}
$$

where

rain_nsta is the number of precipitation measurement stations with the value of psta_nuse equal to 1 , maximum value $=$ dimension nrain; and

temp_nsta is the number of air-temperature measurement stations with the value of tsta_nuse equal to 1 , maximum value $=$ dimension ntemp.

Finally, precipitation and maximum and minimum air temperature values for each HRU are computed as:

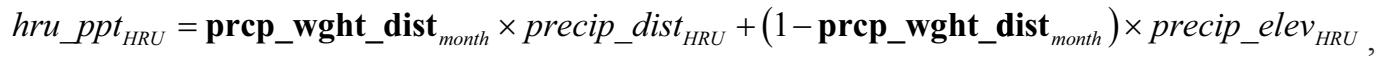

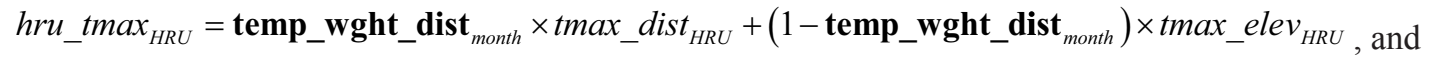

$$
\begin{aligned}
& h r u \_t m i n_{H R U}=\text { temp_wght_dist }{ }_{\text {month }} \times \text { tmin_dist }_{H R U}+\left(1-\text { temp_wght_dist }{ }_{\text {month }}\right) \times t m i n \_e l e v_{H R U} \text {. }
\end{aligned}
$$

\section{Climate-by-HRU Distribution Module: climate_hru}

The Climate-by-HRU (CBH) Distribution Module (climate_hru) provides a method to input time-series of historic, current, and projected climate values, pre-distributed to each HRU. This module broadens input of climate forcings from the computation and distribution methods available within PRMS-IV to include the use of any user-determined, climate computation and distribution method outside of a PRMS-IV simulation. Use of the CBH Distribution Module provides a convenient method to investigate a range of potential climate-change scenarios and the impact on water resources.

Seven climate forcing values can be specified: (1) precipitation, (2) maximum and minimum air temperature, (3) potential evapotranspiration, (4) solar radiation, (5) active transpiration, (6) wind speed, and (7) relative humidity. These values are read from separate CBH Files for each data type, one file for types 1, 3, 4, 5, 6, and 7 and two for type 2. To use a CBH File for a data type, set one or more of the control parameters temp_module, precip_module, et_module, solrad_module, or transp_module to Climate_hru. For input of humidity and wind-speed values set control parameters humidity_cbh_flag and windspeed_cbh_flag to 1, respectively. Wind speed and relative humidity CBH Files are required for the Penman-Monteith potential evapotranspiration distribution module (control parameter et_module = potet_pm) described in this report (see the "Potential Evapotranspiration Modules" section). 
Data types not specified using CBH Files are computed and distributed to each HRU using the selected climate distribution module. For example, if potential evapotranspiration values are not input in a $\mathrm{CBH}$ file, they will be computed for each HRU and time step by the module specified for the value of potet_module. Any combination of these data types can be input to a simulation. Thus, one to seven types and up to eight $\mathrm{CBH}$ files can be input to a simulation.

CBH files are identical in format to the PRMS Data File (see Appendix 2 for a description of the Data File format). As with Data Files, the time period spanned in each CBH File can be different, as long as the selected simulation time period is included within each file. Inclusion of Data File along with specification of values in a CBH file for one or more data type can be helpful for comparison purposes. For example, if a $\mathrm{CBH}$ precipitation file is used to input distributed-precipitation values, then measured precipitation values also can be input in the Data File. In any case, a Data File is required for all simulations, even if all climate data are specified in CBH Files; at a minimum, the Data File must include columns for the daily simulation time increments and at least one column of measured values. For example, measured streamflow values could be the only column(s) specified in the Data File.

A method of generating CBH input file(s) is to have one or more of the PRMS-IV climate distribution modules compute and output HRU climate values to a file, then the CBH Distribution Module can read the values from this file for a subsequent simulation. A CBH file generated in this manner is described in the "Climate-by-HRU Files" section of Appendix 2. An example of a user-determined method is to distribute precipitation from a time-series grid to each HRU with an area-weighted overlay between the precipitation grid map and HRU map. Examples of precipitation grids include: results from general circulation and regional climate models and DAYMET (Thornton and others, 2012, Thornton and others, 1997) and radar data sets. The source time-series climate values can be grids or polygons of any spatial resolution that provides sufficient information to represent the climate information required at the HRU spatial resolution.

There is no allowance for missing or invalid values when using the climate_hru module; thus, the user must ensure that the input values are valid for all HRUs and time steps in each CBH file. If errant values are input to the climate_hru module during the selected simulation time period an error message is issued and execution halts. If the $\mathrm{CBH}$ file does not include the full specified simulation time period, an error message is issued and execution halts.

The climate_hru module allows for calibration of precipitation and air temperature values using multiplicative and additive parameters, respectively. Monthly precipitation adjustments are applied by HRU or subbasin, using parameters rain_cbh_adj and snow_cbh_adj or parameters rain_sub_adj and snow_sub_adj, respectively. The form of precipitation is determined in the same manner as all other Precipitation-Distribution Modules. Users can set parameter $\mathbf{a d j} \mathbf{b}_{\mathbf{b}} \mathbf{b} \mathbf{h r u}$ to 0 to adjust by subbasin or 1 to adjust by HRU. Temperature adjustment factors are applied by HRU (parameters tmax_cbh_adj and tmin_cbh_adj). Input parameters and input and output variables for module climate_hru are described in tables 1-3 and $1-5$, respectively.

\section{Solar-Radiation Distribution Modules}

Computed daily shortwave radiation (swrad) for each HRU is estimated by using one of three methods. The first, module ddsolrad, is a modification of the degree-day method described by Leaf and Brink (1973). The second, module ccsolrad, uses (1) a relation between sky cover and daily range in air temperature and (2) a relation between solar radiation and sky cover. The third option is to input solar radiation values that have been pre-distributed to each HRU and input using the climate hru module that is described in the "Climate-by-HRU Distribution Module" section in this appendix. The input parameters used to compute the shortwave radiation variables and are defined in table 1-3. The input and computed variables are defined in table 1-5. Equation symbols, used in this section, that correspond directly to PRMS-IV input or output, are defined in these two tables.

\section{ddsolrad}

Module ddsol rad computes shortwave solar radiation with a modified degree-day method (Leavesley and others, 1983). This method was developed for the Rocky Mountain region of the United States. It is most applicable to regions where predominantly clear skies prevail on days without precipitation.

The modified degree-day method is shown graphically in the coaxial relation of figure 1-3. A daily maximum temperature is entered in the $\mathrm{X}$-axis of part A and intersects the appropriate month line (parameters dday_slope and dday_intep). These lines express the relationship between monthly maximum air temperature and the degree-day coefficient $(d d)$. From this intersection point, one moves horizontally across the degree-day coefficient axis and intersects the curve in part $B$. From this point, the ratio of actual-to-potential radiation for a horizontal surface (solf) can be obtained. 


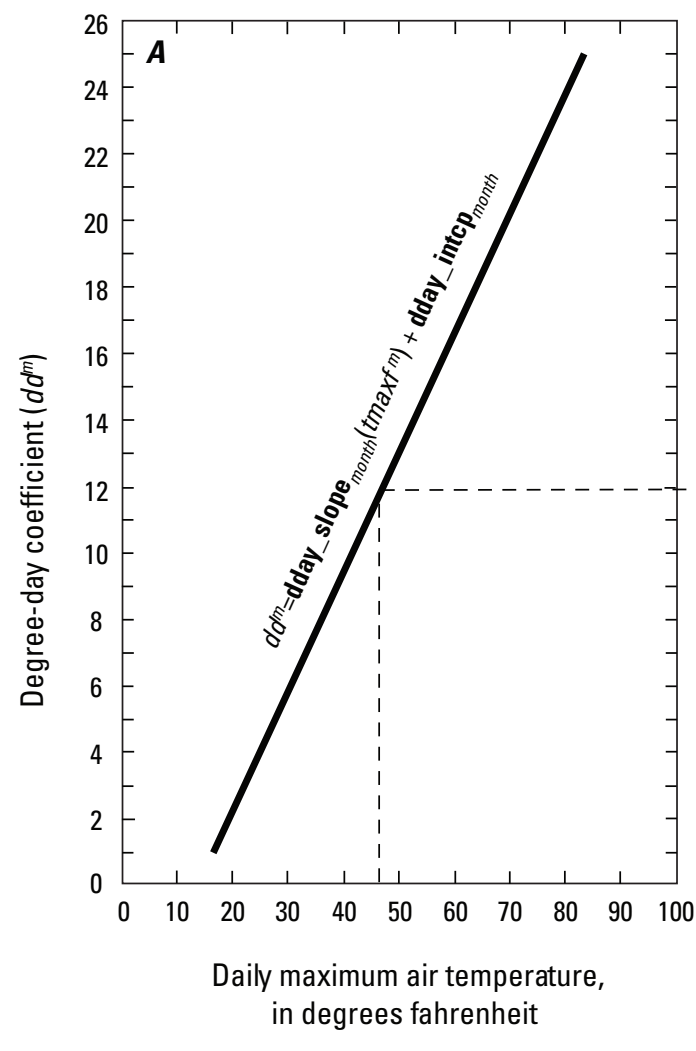

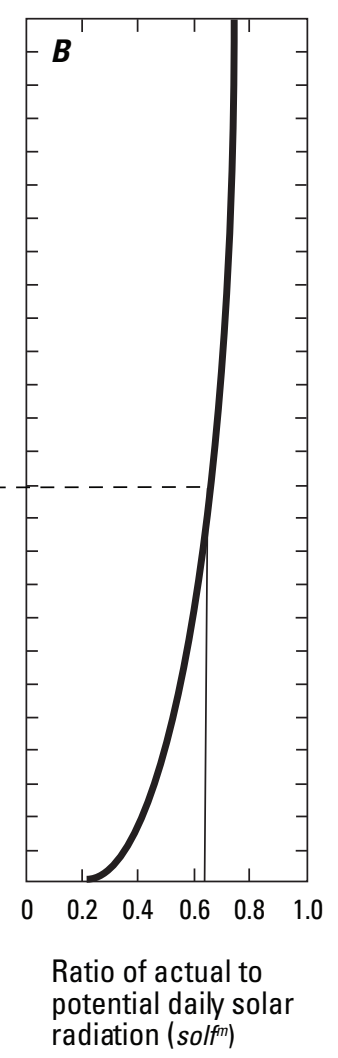

Figure 1-3. Example of coaxial relationship for estimating short-wave solar radiation from maximum daily air temperature developed for northwestern Colorado (modified from Leavesley and others, 1983). (dd, degree-day coefficient; solf, ratio of actualto-potential radiation for a horizontal surface; the superscript $m$ refers to the index for monthly values).

Then, the short-wave radiation ( $\mathrm{swrad}$ ) for each HRU is calculated according to:

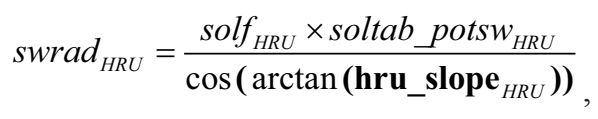

where

$$
\text { soltab_potwsHRU is computed according to equation } 6 .
$$

The ratio solf is developed for days without precipitation; thus, the computed value of swrad from equation 1-45 is for dry days. For days with precipitation greater than the monthly parameter ppt_rad_adj, swrad is adjusted according to:

$$
\operatorname{swrad}_{H R U}=\text { swrad }_{H R U} \times \text { rad_adj }
$$

where

$$
\text { rad_adj is radj_sppt for summer days and radj_wppt for winter days. }
$$

Monthly values of dday_slope and dday_intep can be estimated from historical air-temperature and solar-radiation data. One method is to make monthly plots of solar radiation versus their daily degree-day coefficients, $d d$, for days without precipitation. The $d d$ values for this plot are computed by using figure 1-3, and the daily solf ratios computed from historical data. A more rapid and coarse procedure is to establish two points for each monthly line by using some average values. One point for each month is estimated by using the average solf and average maximum temperature for days without precipitation. The second point is estimated by using the maximum observed temperature for each month and a $d d$ value of 15 . Estimates of radj_sppt and radj_wppt can be obtained by comparing historical solar radiation on days with precipitation to amounts of solar radiation on days without precipitation for summer and winter days, respectively. 


\section{ccsolrad}

The computation of solar radiation on each HRU, using a relation between sky cover and daily range in air temperature and a relation between solar radiation and sky cover, is performed by module ccsol rad. This procedure is applicable to more humid regions where extensive periods of cloud cover occur with and without precipitation.

The cloud-cover method (as described by Leavesley and others, 1983) uses a relationship between solar radiation and sky cover developed by Thompson (1976) and a relationship between sky cover and a daily range in air temperature demonstrated by Tangborn (1978). Daily clear sky (sky) is computed as:

$$
s k y=1-\mathbf{c c o v} \_\mathbf{s l o p e _ { m o n t h }} \times(\text { solrad_tmax }- \text { solrad_t } t \min )+\text { ccov_intep }_{\text {month }}
$$

With this, solar radiation on a horizontal surface ( $\mathrm{rad}$ ) can be estimated as:

$$
\text { orad }=\text { MAX }\left[\left(\text { crad_coef }+(1-\text { crad_coef }) \times(s k y)^{\text {crad_exp }}\right), \text { radmax }\right] \times \text { soltab_basinpotsw },
$$

where

$$
\text { soltab_basinpotsw is computed according to equation } 6 \text { for each day of the year. }
$$

Finally, the short-wave radiation ( $\mathrm{swrad}$ ) is computed by adjusting for the slope of the HRU, according to:

$$
\operatorname{swrad}_{H R U}=\frac{\text { soltab_pots } w_{H R U} \times \text { orad }}{\text { soltab_basinpotsw } \times \cos \left(\arctan \left(\mathbf{h r u} \text { slope }_{H R U}\right)\right)}
$$

For days with precipitation, swrad is adjusted by the monthly parameter ppt_rad_adj, according to equation 1-46.

\section{Transpiration Period Modules}

The period of active transpiration is determined for each HRU by one of three user-specified methods. The first, modules transp_frost and frost_date, uses the killing frost approach (Christiansen and others, 2011). The second, module transp tindex, uses a temperature index approach. The third option is to input transpiration values that have been pre-distributed to each HRU and input using the climate hru module that is described in the "Climate-by-HRU Distribution Module" section in this appendix. The input parameters used for the transpiration modules transp_frost and transp_tindex are defined in table 1-3. The input and computed variables are defined in table 1-5.

\section{transp_frost and frost_date}

The first option for determination of the period of active transpiration, or growing-season length, (module transp frost) uses the killing frost approach (Christiansen and others, 2011). The growing-season length for each HRU can be defined as the time between the last (parameter spring_frost) and first (parameter fall_frost) freezing air temperatures (U.S. Department of Agriculture National Agricultural Statistics Service [NSS], 1999) and has been used in numerous studies (Wang, 1963; Brinkman, 1979; Cooter and LeDuc, 1995; Kunkel and others, 2004).

The module frost date can be used to determine the parameters spring_frost and fall_frost and writes them in the Parameter File "frost_date.param". This module uses the method described by the U.S. Army Corps of Engineers (1987) and is activated by setting the control parameter model_mode to FROST. The input parameters used to compute the frost date outputs and are defined in table 1-3. The input and computed variables are defined in table 1-5.

\section{transp_tindex}

The second option for determination of the period of active transpiration (module transp_tindex) uses a temperature index approach. This module computes a temperature index that is the cumulative sum of daily maximum temperature for each HRU after the model reaches the transpiration starting month (parameter transp_beg). The period of active transpiration for 
each HRU begins once the temperature index reaches a threshold (parameter transp_tmax). The period of transpiration for each HRU is terminated when the simulation reaches the month specified by parameter transp_end.

\section{Potential Evapotranspiration Modules}

Potential evapotranspiration (PET) is computed for each HRU by one of seven user-specified options. Selection of a particular PET module will depend on the information available to the modeler. The least sophisticated PET modules require measured air-temperature information, whereas the more sophisticated modules can additionally require measured shortwave solar radiation, atmospheric pressure, relative humidity, and wind speed. There are also two modules that allow measured (or externally computed) PET to be input directly to PRMS-IV.

The first option (module potet_jh) uses the modified Jensen-Haise formulation (Jensen and Haise, 1963; Jensen and others, 1969). The second option (module potet_hamon) uses the empirical Hamon formulation (Hamon, 1961). The third option (module potet_hs) uses the Hargreaves-Samani formulation (Hargreaves and Samani, 1985). The fourth option (module potet_pt) uses the Priestley-Taylor formulation (Priestley and Taylor, 1972). The fifth option (module potet_pm) uses the Penman-Monteith formulation (Penman, 1948; Monteith, 1965). The sixth option (module potet_pan) is used when panevaporation data from one or more measurement stations are available and the measured data can be applied to each HRU. The seventh option is to input PET values that have been pre-distributed to each HRU and input using the climate_hru module that is described in the "Climate-by-HRU Distribution Module" section in this appendix.

The input parameters used to compute the variables for the PET modules are defined in table 1-3. The input and output variables are defined in table 1-5. Equation symbols used in this section, which correspond directly to PRMS-IV input or output, are defined in these two tables.

\section{potet_jh}

The first option (module potet_ $j$ h) uses the modified Jensen-Haise formulation to compute PET (potet) for each HRU. PET is computed as a function of air temperature, solar radiation, and two coefficients, parameters jh_coef and jh_coef_hru, which can be estimated by using regional air temperature, elevation, and saturation vapor pressure. PET for each HRU is calculated as:

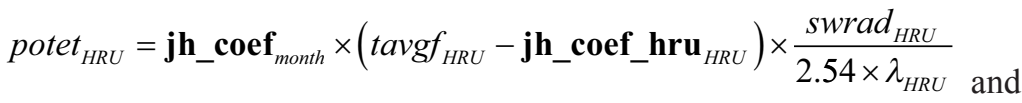

$$
\begin{aligned}
& \lambda_{H R U}=597.3-\left(0.5653 \times \operatorname{tavg} f_{H R U}\right),
\end{aligned}
$$

where

$\lambda_{H R U}$ is the latent heat of vaporization on the HRU, calories/gram.

The air temperature parameter (parameter jh_coef_hru) used in Jensen-Haise PET computations can be estimated for each HRU as:

$$
\text { jh_coef_hru }{ }_{\mathrm{HRU}}=27.5-\left[0.25 \times\left(\rho_{\text {high_temp }}-\rho_{\text {low_temp }}\right)\right]-\frac{\text { hru_elev }_{\text {HRU }}}{1000} \text {, }
$$

where

$$
\begin{aligned}
& \rho_{\text {high_temp }} \text { is the saturation vapor pressure, in millibars, for the mean maximum air temperature for the warmest month of } \\
& \text { the year; and } \\
& \rho_{\text {low_temp }} \text { is the saturation vapor pressure, in millibars, for the mean minimum air temperature for the warmest month of } \\
& \text { the year. }
\end{aligned}
$$


For a rough estimate, assume rlow_temp is 10.02 millibars and rhigh_temp is 31.67 millibars. Thus, equation 52 is simplified to:

$$
\text { jh_coef_hru }{ }_{\mathrm{HRU}}=22-\frac{\text { hru_elev }_{H R U}}{1000} \text {. }
$$

\section{potet_hamon}

The second option (module potet_hamon) uses the empirical Hamon formulation, in which PET is computed as a function of daily mean air temperature and possible hours of sunshine, according to Hamon (1961), Murray (1967) and Federer and Lash (1978).

PET is calculated as:

$$
\begin{gathered}
\text { potet }_{H R U}=\text { hamon_coef } \mathbf{h R U}_{H R U} \times\left(\frac{\text { soltab_sunhrs }_{H R U}}{12}\right)^{2} \times \rho_{H R U} \text {, and } \\
\rho_{H R U}=216.7 \times \frac{6.108 \times e^{\left(\frac{17.26939 \times \text { tavg } c_{H R U}}{\text { tavg }_{H R U}+237.3}\right)}}{\operatorname{tavgc}_{H R U}+273.3},
\end{gathered}
$$

where

$$
\begin{array}{ll}
\rho_{\text {HRU }} & \text { is the saturated water-vapor density (absolute humidity), grams per cubic meter; and } \\
\text { soltab_sunhrs } & \text { is the number of hours between sunrise and sunset (equation 1-5). }
\end{array}
$$

\section{potet_hs}

The third option (module potet hs) uses the Hargreaves-Samani formulation, in which PET is computed as a function of daily air temperature and solar radiation according to Hargreaves and Allen (2003, equation 8):

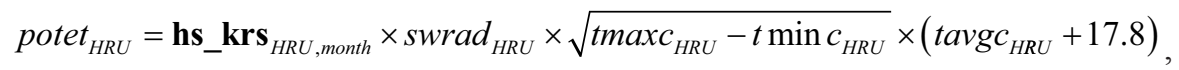

\section{potet_pt}

The fourth option (module potet_pt) uses the Priestley-Taylor formulation, in which PET is computed as a function of daily air temperature, atmospheric pressure, and solar radiation according to Priestly and Taylor (1972). The psychrometric constant (psycnst), in kilopascals per degrees Celsius, for each HRU is computed:

$$
\text { psycnst }_{H R U}=1.6286 \times \frac{101.3-\left(0.003215 \times \mathbf{h r u}_{-} \mathbf{e l e v}_{H R U}\right)}{\lambda_{H R U}},
$$

where

$\lambda_{H R U}$ is the latent heat of vaporization on the HRU, calories/gram (equation 1-51) and hru_elev $\mathbf{H}_{H R}$ is the HRU elevation in feet.

The slope of saturation vapor pressure versus air temperature curve ( $\left.v p \_s l o p e\right)$, in kilopascals per degrees Celsius, according to Irmak and others (2012), for each HRU is computed as: 


$$
v p \_s l o p e_{H R U}=\frac{4098 \times\left(0.6108 e^{\frac{17.26939 \times \operatorname{tavgc}_{\mathrm{HRU}}}{\operatorname{tavgc}_{H R U}+237.3}}\right)}{\left(\operatorname{tavgc}_{H R U}+237.3\right)^{2}} .
$$

The heat flux density to the ground $(G)$, in megajoules per square meter per day, according to Lu and others (2005) for each HRU is computed as:

$$
G_{H R U}=-4.2 \times\left(\operatorname{tavg} c_{H R U}^{m-1}-\operatorname{tavg} c_{H R U}\right)
$$

Finally, PET is computed for each HRU according to Priestley and Taylor (1972, equation 8):

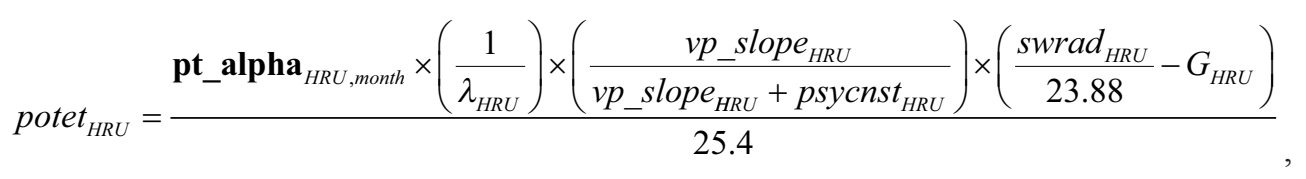

where

23.88 converts the units of Langleys per day to megajoules per square meter per day; and

25.4 converts the units of millimeters to inches.

\section{potet_pm}

The fifth option (module potet_pm) uses a Penman-Monteith formulation in which PET is computed as a function of air temperature, atmospheric pressure, relative humidity, wind speed, and solar radiation. The temperature at dew point (tempc dewpt), in degress Celsius, according to Murray (1967), as defined by equation 13 in Irmak and others (2012), for each HRU is calculated as:

$$
\text { tempc_dewpt } t_{H R U}=\frac{237.3}{\left[1\left(\ln \left(\frac{\text { humidity_hru }_{H R U}}{100}\right) / 17.26939\right)+\left(\frac{\operatorname{tavgc}_{\text {HRU }}}{237.3}+\operatorname{tavgc}_{H R U}\right)\right]_{-1}} \text {, }
$$

where

humidity_hru $u_{h r u}$ is the relative humidity, decimal fraction, input in a $\mathrm{CBH}$ file.

The actual vapor pressure (evp_actual) in kilopascals as shown in Irmak and others (2012) for each HRU is calculated as:

$$
v p \_a c t u a l_{H R U}=0.6108 e^{\frac{\text { tempc_dewpt }_{H R U} \times 17.26939}{\text { tempc_dewpt }_{H R U}+237.3}} .
$$

Saturated vapor pressure ( $v p \_s a t$ ) in kilopascals for each HRU is calculated according to Irmak and others (2012):

$$
v p \_s a t_{H R U}=\frac{0.6108 \times\left(e^{\frac{\operatorname{tmaxc}_{H R U} \times 17.26939}{\operatorname{tmaxc}_{H R U}+237.3}}-e^{\frac{t \min c_{H R U} \times 17.26939}{t \min c_{H R U}+237.3}}\right)}{2} .
$$

The vapor pressure deficit ( $v p \_$deficit), in kilopascals, for each HRU is computed as:

$$
v p \_ \text {deficit }_{H R U}=v p_{-} s a t_{H R U}-v p_{-} a c t u a l_{H R U} .
$$

The net long-wave radiation is the difference between outgoing and incoming long-wave radiation, in megajoules per square meter per day, is computed according to Irmak and others (2012): 


$$
\begin{aligned}
\text { lwrad_net }_{H R U}=( & \left.4.903 \times 10^{-9}\right) \times\left(\operatorname{tavg}_{H R U}+273.16\right) \times\left(0.34-0.14 \sqrt{v p_{-} \text {actual }_{H R U}}\right) \\
& \times\left(1.35 \times \frac{\text { swrad }_{H R U}}{\text { soltab_pots }_{H R U}}-0.35\right)
\end{aligned}
$$

where

soltab_potsw $w_{H R U}$ is the potential radiation for a horizontal surface (equation 1-6).

Finally, the Penman-Monteith equation can be solved for a daily time step for each HRU according to Irmak and others (2012):

$$
\begin{aligned}
& \text { potet }_{H R U}=\frac{0.408 \times v p \_s l o p e_{H R U} \times\left(\frac{\text { swrad }_{H R U}}{23.88}-G_{H R U}\right)}{v p_{-} \text {slope }_{H R U}+\left(\gamma_{H R U} \times\left(1+\mathbf{p m} \_\mathbf{d} \_ \text {coef }_{H R U, \text { month }} \times \text { wind_speed }_{H R U}\right)\right)} \\
& +\frac{\gamma_{H R U} \times\left(\frac{\mathbf{p m} \_\mathbf{n} \_\mathbf{c o e f}}{\operatorname{tavgc}_{H R U}+273.16}\right) \times \text { wind_speed }_{H R U} \times v p \_d e f i c i t_{H R U}}{v p \_s l o p e_{H R U}+\left(\gamma_{H R U} \times\left(1+\mathbf{p m} \_\mathbf{d} \_ \text {coef }_{H R U, \text { month }} \times \text { wind_speed }_{H R U}\right)\right)} \text {, }
\end{aligned}
$$

where

$G_{H R U}$ is the heat flux density to the ground, in megajoules per square meter per day (equation 1-59).

\section{potet_pan}

The sixth option (module potet_pan) is used when pan evaporation data from one or more measurement stations are available. The station associated with each HRU is specified by parameter hru_pansta. PET is computed from the measured pan evaporation and a monthly coefficient. Daily PET for each HRU is calculated as:

$$
\text { potet }_{H R U}=\text { epan_coef }{ }_{\text {month }} \times \text { pan_evap } p_{\text {hru_pansta. }} \text {. }
$$

\section{Interception Module: intcp}

Interception of precipitation by the plant canopy ( $\left.h r u \_i n t c p \_s t o r\right)$ and net precipitation (net_ppt) are computed as a function of plant-cover density and the storage in each HRU by using module intcp. The input parameters used to compute the interception variables are defined in table 1-3. The input and computed variables are defined in table 1-5. Equation symbols used in this section that correspond directly to PRMS-IV input or output are defined in these two tables.

During the summer (transp_on $=1$ ), plant-cover density assumes the value of covden_sum; during winter (transp_on $=0$ ), plant-cover density assumes the value of covden_win. Similarly, the storage capacity of rain on the canopy will vary between summer, srain_intep; and winter, wrain_intep. Snow capacity, snow_intep, has a single value because the majority of snow occurs only during winter. The ability to intercept and sublimate snow above the ground is a function of the plant-cover type, cov_type. Water bodies (parameters cov_type $=0$ and hru_type $=2$ ) cannot store rain or snow; grass (cov_type $=1$ ) can intercept rain but not snow, because it will be buried under the snow; and shrubs and trees (cov_type $=2$ and 3, respectively) will intercept both rain and snow.

An artifact of the two-mode canopy (summer/winter) is that an adjustment is made to account for the changing canopy density on the first day of winter and the first day of summer. The effect is that water stored on a summer canopy falls as throughfall based on the difference between the summer and winter canopy density with the remainder remaining in the canopy on the first day of winter . Similarly, the depth of water on the last day of winter will be adjusted based on the difference between the winter and summer canopy density on the first day of summer, which typically decreases as a result of spreading the finite volume to a larger plant canopy area, that is, the summer canopy density is greater than the winter canopy density. On all days except for the first day of winter, intercepted rain is assumed to evaporate at a free-water surface rate. Intercepted snow is assumed to sublimate at a rate that is expressed as a decimal fraction of the potential evapotranspiration (parameter potet_sublim). 
Precipitation that exceeds the available canopy storage capacity will become throughfall. Available storage capacity (AvailCanSto) and throughfall of rain in the summer (Ptf) for each HRU are computed as:

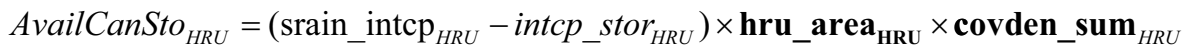

when

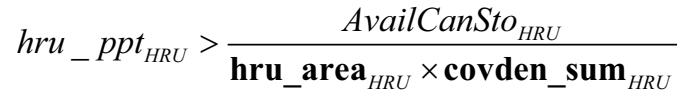

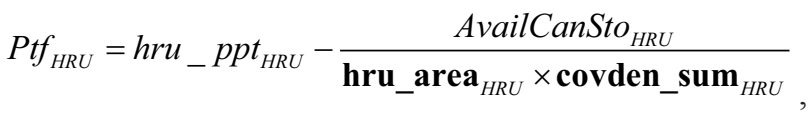

otherwise

$$
P t f_{H R U}=0.0
$$

where

AvailCanSto $_{H R U}$ is the available storage in the plant canopy of the HRU, in acre-inch; and

$P t f_{H R U} \quad$ is the precipitation throughfall on the HRU, in inches.

The precipitation that reaches the ground during the time step is referred to as net precipitation (net ppt) and is the sum of throughfall and precipitation on the HRU not covered by plants. Net precipitation (in summer) for each HRU is calculated according to:

$$
n e t_{-} p p t_{H R U}=h r u_{-} p p t_{H R U} \times\left(1.0-\text { covden_sum }{ }_{H R U}\right)+\left(P t f_{H R U} \times \text { covden_sum }{ }_{H R U}\right) \text {. }
$$

\section{Snow Module: snowcomp}

The module snowcomp is always called by PRMS-IV and does not need to be specified in the Control File. The input parameters used to compute the snow computation variables are defined in table 1-3. The input and computed variables are defined in table 1-5. Equation symbols used in this section that correspond directly to PRMS-IV input or output are defined in these two tables.

\section{General Theory}

PRMS-IV simulates the initiation, accumulation, and depletion of a snowpack on each HRU. Snowpack dynamics are simulated through estimates of water and energy balances. These balances conserve mass and energy, such that the difference between inputs and outputs is equal to the change in snowpack storage (see fig. 3 of the main body of this report).

Water input to the snowcomp module includes the form and net amount of precipitation reaching the snowpack as computed by the Precipitation-Distribution and Interception modules. Water outputs from the snowcomp module are snow-water equivalent storage in the snowpack (pkwater_equiv), melt (snowmelt) and sublimation (snow_evap). Melt water becomes input to the Surface-runoff and Soil Zone Modules (srunoff_carea, srunoff_smidx, and soilzone, respectively) described in this appendix. Sublimation is a component of the actual evapotranspiration from each HRU (hru_actet).

Storage within the snowpack is tracked in two states: ice (solid) and free water (liquid). The amount of free water in the snowpack is determined by the freeze-thaw cycles of the energy balance and the physical capacity of the space between the individual ice crystals in the snowpack to hold free water. The total amount of water in a snowpack is expressed as a snow-water equivalent (SWE), which is the volume of water that would result from melting all of the ice to liquid form, and does not include the air space. 
Energy can be exchanged between the snowpack and the atmosphere in both directions through radiation, conduction, or convection. A precipitation event occurring at a temperature other than freezing also will affect the energy storage of the snowpack. The reference energy state for snowpacks, simulated by the snowcomp module, is the freezing point of water, or an all-ice isothermal snowpack at $0{ }^{\circ} \mathrm{C}$. When the snowpack has energy above this state, some ice will melt and produce a volume of free water on the basis of the latent heat of fusion of water. If the volume of free water exceeds the pore space of the snowpack, then snowmelt exits the snowpack and is an output of both water and latent energy from snowpack storage. Regardless of the amount of energy entering the snowpack, the temperature will never exceed $0{ }^{\circ} \mathrm{C}$. When the snowpack lacks enough energy to be isothermal at $0{ }^{\circ} \mathrm{C}$, all water will be frozen and the snowpack temperature will drop below $0{ }^{\circ} \mathrm{C}$. This lack of energy is accounted for as a heat deficit, or the amount of energy per unit area that is required to bring the snowpack back to an isothermal condition of $0{ }^{\circ} \mathrm{C}$. The heat deficit and temperature are related by the specific heat of ice and SWE of the snowpack.

Other important structural characteristics of the snowpack that are simulated are albedo (albedo), average density ( $\left.p k \_d e n\right)$, and snow-covered area of the HRU (snowcov_area). Albedo determines how much radiation is reflected from the snow surface, density is used to estimate thermal conductivity of the snowpack, and snow-covered area is used to determine what proportion of water balance outputs are affecting the snowpack SWE.

\section{Simulation Details}

Storage and fluxes within the snowpack are generally computed in units of depth-per-unit-area and depth-per-unit-area per time, respectively. Similar to the snowpack SWE, the unit depth of falling snow in this module applies to liquid water content only, not a depth of new fallen snow. When depth is applied over a specific area (for example, an inch of SWE on an HRU), the absolute volume can be determined by multiplying the depth by the area.

Energy states and fluxes are computed in units of Langleys (calories per square centimeter) and Langleys per time, respectively. Calculations of energy exchange (latent or specific heat) are directly applied to volumes of water to determine the energy flux. When computing heat energy in Langleys, the snowcomp module defines water volume as depth in inches over area in square centimeters $\left(\mathrm{cm}^{2}\right)$. This mixture of units tends to cancel out, which simplifies the calculations. For example, snowpack heat deficit ( $p k \_d e f$ in Langleys) for each HRU can be computed directly from snowpack temperature ( $\left.p k \_t e m p<0{ }^{\circ} \mathrm{C}\right)$ and $\mathrm{SWE}$ (pkwater_equiv in inches):

$$
p k \_d e f_{H R U}=-p k \_t e m p_{H R U} \times p k w a t e r \_e q u i v_{H R U} \times 1.27,
$$

where

$$
\text { 1.27 is the specific heat of ice, calories per inch per square centimeter per degrees Celsius. }
$$

This internal unit of volume (inch-square centimeters) is important when interpreting the constants used in internal functions of the snowcomp module (for example, specific heat of water or ice and latent heat of fusion), but typically will not affect the interpretation of any simulated results.

The snowcomp module runs on a daily time step. Each calculation averages or aggregates over the day, with the exception of the energy balance, which is divided into two half days (day and night). The snow module performs the water and energy balance calculations in five sequential steps:

1. Compute the amount of incoming water and energy changes due to precipitation, including potential for generating melt.

2. Compute the change in snow-covered area.

3. Compute the change in albedo.

4. Apply the remainder of the energy flux (radiant, convective, and conductive exchanges) to changing the temperature of the snowpack for production of snowmelt.

5. Compute sublimation and evaporation losses.

These steps are computed for each HRU. Note that snowmelt can be generated in both steps one and four.

\section{Precipitation}

The snowcomp module requires estimates of the net rain and net snow that fall on the snowpack for each HRU. In addition, atmospheric temperatures also must be available to estimate the energy state of the incoming precipitation. There are three major steps to estimating the effects of precipitation on the snowpack: 
1. Determine the temperature of rain and/or snow.

2. Apply the effects of rain.

3. Apply the effects of snow.

Because the rain is applied to the snowpack before the snow, mixed daily events that start as rain and change to snow are most accurately simulated.

\section{Precipitation Temperature}

Computation of precipitation temperature differs between days of mixed precipitation and days of all-rain or all-snow precipitation. If the precipitation is all rain or all snow, then the average temperature of the precipitation is assumed to be the average of the minimum and maximum air temperature for the day. There is an exception for all-rain days that have an average temperature at or below $0{ }^{\circ} \mathrm{C}$. For example, within a 24-hour period there can be rain during the daylight period, but no snow during a very cold night. If this type of event occurs, the snowcomp module treats the precipitation as if it were mixed in form. This more accurately captures the energy-deficit nature of the precipitation. When rain occurs with below-freezing temperatures or with snow, the rain temperature is estimated as the average of the maximum air temperature over the day and the threshold for maximum air temperature, below which precipitation is all snow (parameter tmax_allsnow). Estimation of snow temperature on a mixed day depends on the preexistence of a snowpack. If a snowpack already exists, the snow temperature is estimated as the average of the minimum air temperature over the day and the parameter tmax_allsnow. If there is no existing snowpack, the snow temperature is estimated as the average air temperature over the day, similar to an all-snow day.

\section{Effects of Rain}

Rain adds both free water and energy to the snowpack. The snowpack heat deficit cools the incoming water to $0{ }^{\circ} \mathrm{C}$ and releases latent heat as the liquid water freezes. For rain at a given temperature (train), the amount of incoming energy (caln in Langleys per inch) for each HRU is calculated as:

$$
\operatorname{caln}_{H R U}=203.2+2.54 \times \operatorname{train}_{H R U},
$$

where

203.2 is latent heat released by each inch of freezing rainwater, in calories per inch per square centimeter (that is, 80 calories per cubic centimeter); and

2.54 is the amount of heat released by each inch of cooling rain for each degree Celsius of cooling, in calories per inch per square centimeter per degree Celsius (the specific heat of liquid water is 1 calorie per cubic centimeter per degree Celsius).

Because the heat deficit is defined as the amount of energy required to bring the snowpack to isothermal, it is straightforward to determine if the snowpack has any capacity to freeze incoming rain. To freeze rain, the heat deficit must be greater than 0 , and the energy added by incoming rain is first applied to reducing the heat deficit toward 0 . If the heat deficit is sufficient to cool and freeze all of the rain, then all incoming rain becomes snowpack ice and the heat deficit is reduced by the appropriate amount. Any time the heat deficit ( $p k \_d e f$ ) of an HRU changes without going to 0 , a new snowpack average temperature is calculated as:

$$
p k_{-}{ }_{\text {temp }} p_{H R U}=\frac{-1 \times p k_{-} d e f_{H R U}}{1.27 \times p k w a t e r_{-} e q u i v_{H R U}} \text {, }
$$

where

pkwater_equiv $v_{h r u}$ is the SWE of the snowpack, inches; and

1.27 is the specific heat of ice, in calories per inch per square centimeter per degree Celsius.

This result will be negative (below $0{ }^{\circ} \mathrm{C}$ ), when a heat deficit exists. If the heat deficit is not sufficient to cool and freeze all of the rain, then the energy from the rain brings the snowpack to isothermal at $0{ }^{\circ} \mathrm{C}$, and any excess energy is applied to melt existing ice in the snowpack. If the total resulting free water exceeds the capacity for free-water storage, then snowmelt occurs and both water and energy exit the snowpack. The capacity to hold water (parameter freeh2o_cap) is generally a fractional value between 0.02 and 0.05 of the ice SWE in the snowpack (U.S. Army, 1956; Leaf, 1966). 


\section{Effects of Snow}

New snow adds to the ice content of the snowpack. If the new snow is at $0{ }^{\circ} \mathrm{C}$, then there is no change to the heat deficit of the snowpack. Though the deficit does not change, the snowpack temperature will increase if the snowpack was colder than $0{ }^{\circ} \mathrm{C}$ before the new snow fell. If the original snowpack has a heat deficit, the temperature is readjusted according to equation 1-74.

If the new snow is colder than $0{ }^{\circ} \mathrm{C}$, then the redistribution of heat after the new snowfall can both freeze water and/or increase the heat deficit. The heat deficit of the new snow is calculated identically to that of the snowpack in equation 1-74, with the calculation applied only to the new snow (net_snow) rather than the whole snowpack (pkwater_equiv). The heat deficit of the new snow is first applied to freezing any free water in the snowpack. Then, if heat deficit from new snow has not been consumed by freezing free water, the remainder adds to the heat deficit of the overall snowpack. When the snowpack is all ice before the new snow, the heat deficit in the new snow is simply added to the snowpack heat deficit.

\section{Snow-Covered Area}

The snow-covered area is determined from the SWE by a depletion curve (Anderson, 1973). When SWE is below a defined threshold (parameter snarea_thresh) but is increased by new snow, the snow-covered area is always initially set to its maximum value. Then, as the snowpack melts, growing bare patches will gradually reduce the snow-covered area (fig. 1-4).

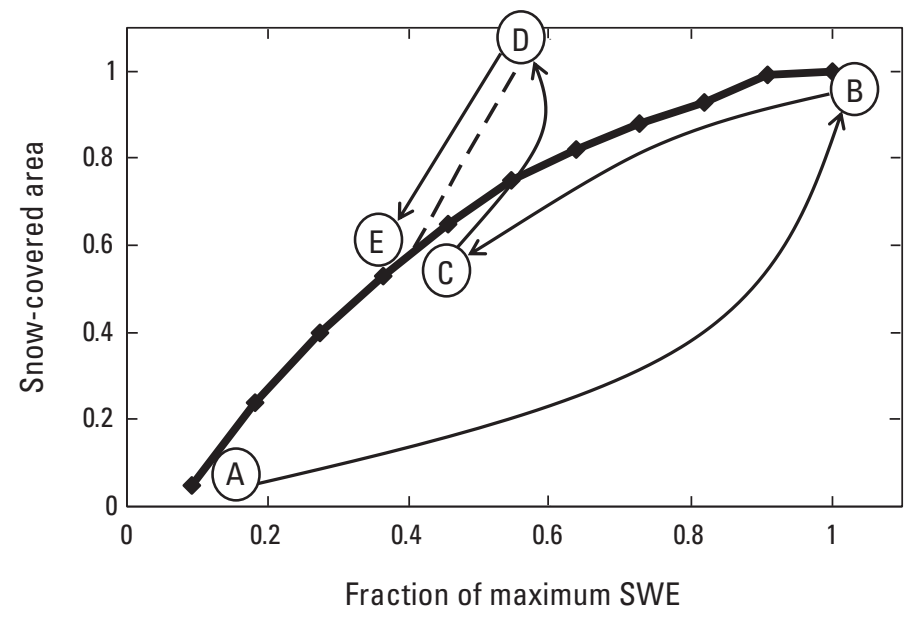

Figure 1-4. Example of a snow-covered area depletion curve (solid line), as defined by 11 points (diamonds). The horizontal axis represents the fraction of the maximum snow-water equivalent (SWE) attained by the modeled snowpack. The vertical axis represents the fraction of maximum land area covered by snow. The dashed line is an example of a linearly interpolated depletion after a secondary snow accumulation. For a hypothetical snowpack, arrows indicate simulations for: (A to $B$ ) initial accumulation, ( $B$ to $C$ ) melt, ( $C$ to $D$ ) secondary accumulation (that is, new snow), and ( $D$ to $E$ ) melt of that secondary accumulation. 
Starting at the maximum snow cover for a given area, the curve characterizing the relationship between declining snowcovered area and SWE is defined by 11 progressively smaller fractions of snow-covered area (parameter snarea_curve), from right to left in figure 1-4. As the snowpack melts, the snow-covered area can be determined by the declining value on the y-axis corresponding to the declining distance along the x-axis that is defined by the ratio of the current SWE to the threshold SWE (parameter snarea_thresh).

When a snowpack is melting, it is possible that a new snowfall will not be sufficient to increase the SWE to the threshold value; however, new snow will always increase the snow-covered area to its maximum. Due to a maximum snow-covered area at a sub-maximum SWE, a different algorithm outside the curve is needed to calculate the snow-covered area until the new snow melts. First, it is assumed that the snow-covered area will remain at the maximum until one-quarter of the new snow melts. Then, it is assumed that the remaining three-quarters of the new SWE needs to melt before the snowpack returns to the original snow-covered area, or the snow-covered area immediately prior to the new snow.

A linear interpolation is used to determine the snow-covered area between the maximum (previous SWE plus three-quarters of the new snow) and the previous location on the depletion curve (SWE before the new snow occurred). The dashed line in figure 1-4 provides an example of this transitory relationship between SWE and snow-covered area. Once the remaining threequarters of the new snow has melted, the snow-covered area is again determined by the depletion curve, resuming from the point of departure when the new snow fell.

An example of this is shown as the melt cycle presented in figure 1-4. A large snowfall creates a snowpack (A to B). This snowpack melts back to 40 percent of its maximum SWE and about 58 percent of its maximum snow-covered area (B to C). A secondary snowfall accumulation occurs that increases the snow-water equivalent to 60 percent of its maximum value, corresponding to a 20 percent increase in SWE and an increase to the maximum snow-covered area (C to D). While the first quarter of the new snow melts ( 5 percent of the maximum SWE), the snow-covered area remains at the maximum. Then, the remaining three-quarters of the 20-percent increase (15 percent of the maximum SWE) must melt before returning to the original depletion curve. While this new snow is melting, the snow-covered area is interpolated along a straight line (dashed line) from the peak at 55-percent maximum SWE (maximum snow-covered area) to the 40-percent maximum SWE level (58 percent of maximum snow-covered area, D to E). Further melt below the 40-percent maximum SWE level follows the original depletion curve (left of E) originally dictated by the A to B increase in SWE maximum.

\section{Albedo}

The amount of short-wave radiant solar energy (swrad) applied to the snowpack is influenced by the albedo (albedo), or "reflectiveness," of the snowpack surface. The albedo quantifies the fraction of total incoming short-wave energy that is reflected from the snow surface, such that 1 minus the albedo is the fraction of short-wave radiation applied to the snowpack energy balance. In other words, freshly fallen snow with a high albedo absorbs less energy and is less likely to melt than older snow with lower albedo. Note that albedo does not affect long-wave radiation from the atmosphere or land cover.

The amount of time since the last new snowfall determines the albedo, where values decrease for each day that there is no new snow. When a substantial new snowfall occurs, albedo is reset to one of two maximum values (fig. 1-5).

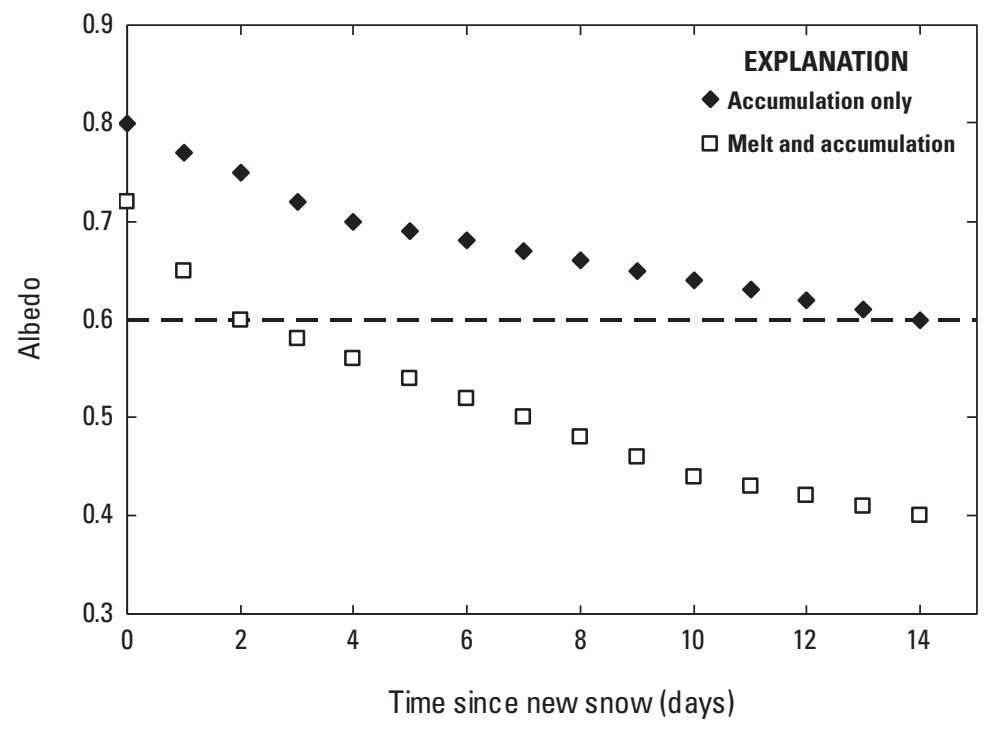

Figure 1-5. Albedo decay curves relative to the number of days since the last new snow. Different curves apply for the snowpack accumulation and melt seasons. Both curves can be used during accumulation season, but only the lower curve will be used during melt season. During accumulation season, the top curve is used for the first 14 days since new snowfall. The dashed line represents the albedo value at which the curves overlap. During melt season, only the lower curve is used. 
The selection of a maximum value depends on whether the snowpack is generally accumulating (higher maximum) or the snowpack is generally melting (lower maximum). The delineation between accumulation and melt seasons is determined by two parameters that indicate whether the snowpack has been in the isothermal state for five consecutive days. Parameter melt_look determines the earliest day when the melt season can begin. Parameter melt_force determines the latest day to force the initiation of melt season. The melt season will never start before the melt_look date. After the melt_look date but before the melt_force date, five consecutive days at an isothermal $0{ }^{\circ} \mathrm{C}$ will trigger the start of melt season. Melt season is active after the melt_force date, whether or not the five-days-at- $0^{\circ} \mathrm{C}$ condition has occurred. This seasonal view of snowpack accumulation and melt is most appropriate in areas where snowpacks tend to persist over a significant portion of the year. For areas where snowpacks are more ephemeral, it may be appropriate to set both the melt_look and melt_force parameters to 1, disabling the higher albedo curve.

For each day without new snow, the albedo is reduced according to the albedo-decay curves (fig. 1-5), where the initial value is the maximum albedo immediately following a new snow. There are two separate curves that correspond to the albedo values for accumulation season and melt season (U.S. Army, 1956). When snow is accumulating, the albedo-decay curve with the higher maximum is used first. After 14 days without snow, the lower albedo decay curve is used. The lower albedo curve is used during melt season. The minimum albedo occurs after 26 days without snow in the accumulation season and after 14 days without snow in melt season.

Depending on the nature of rain or snow, there are two exceptions in the calculation of albedo: (1) rain in a mixed-precipitation event exceeds the parameters albset_rna (during the accumulation season) and albset_rnm (during the melt season), and (2) new snowfall is less than parameters albset_sna (during the accumulation season) and albset_snm (during the melt season).

\section{Energy}

Estimates of exchanges in radiant, sensible, and latent energy depend primarily on interactions at the snow-atmosphere interface and internal conduction within the snowpack. Due to differences between daytime and nighttime atmospheric energy, the energy balance over a given day is calculated separately for the daytime and nighttime periods. In simulating energy transfers over a given day or night, the snowpack is conceptualized as two layers (Obled and Rosse, 1977): (1) a thin surface layer with temperature controlled by the immediate atmospheric conditions and (2) the underlying bulk of the snowpack with temperature controlled by snowpack history. The type and quantity of energy transfer is determined by the energy flow at the surface layer; this results in a temperature gradient between the surface layer and underlying snowpack (see fig. 3 of the main body of this report).

The potential for energy changes in the snowpack is influenced by the snowpack surface-layer temperature. If the average air temperature is less than $0{ }^{\circ} \mathrm{C}$, energy exchanges with the atmosphere are assumed to keep the snow surface layer at the same temperature as the air. When the average air temperature is $0^{\circ} \mathrm{C}$ or greater, the snow surface is $0{ }^{\circ} \mathrm{C}$ because ice cannot be warmer than $0{ }^{\circ} \mathrm{C}$. During the daylight period, the temperature applied to the surface is computed as halfway between the maximum air temperature and the average air temperature. During the night period, the temperature applied to the surface is computed as the average of the minimum air temperature and the average air temperature.

The energy exchange at the snow-atmosphere interface is the sum of short-wave radiation, net long-wave radiation, convection, and latent heat in condensation. The Solar Radiation Distribution module estimates the incoming shortwave radiation ( swrad) that is applied during the daylight period. To calculate the short-wave radiation applied to the snowpack (swn) for each HRU, incoming radiation is limited by the vegetative transmission coefficient parameter ( 0 less than parameter rad_trncf less than 1), (Miller, 1959; Vézina and Péch, 1964; Leavesley and Striffler, 1978) and reduced by the estimated albedo:

$$
s w n_{H R U}=\operatorname{swrad}_{H R U} \times\left(1-\text { albedo }_{H R U}\right) \times \mathbf{r a d} \_ \text {trncf } \mathbf{f}_{H R U} .
$$

Incoming long-wave radiation originates in land cover and the atmosphere. The vegetative canopy is assumed to have the same temperature as the air (temp is either tminc or tmaxc, depending on whether the calculation is for the daylight or night period) and perfect black-body emission ( $l w p)$ relative to that temperature for each HRU, estimated by the following empirical relationship:

$$
l w p_{H R U}=5.85 \times 10^{-8} \times\left(t e m p_{H R U}+273.16\right)^{4},
$$

where

273.16 is a constant that converts temperature in degrees Celsius to degrees Kelvin. 
The total incoming long-wave emission ( $\mathrm{cal}$ ) for each HRU is determined by summing the long-wave emission from the land cover, on the basis of the winter vegetative cover (parameter covden_win), and from the air:

$$
c a l_{H R U}=\text { covden_win }{ }_{H R U} \times l w p_{H R U}+\left(1-\operatorname{covden} \_\mathbf{w i n}_{H R U}\right) \times l w p_{H R U} \times e m i s
$$

where

emis is set to the value of parameter emis_noppt on days with no precipitation; or

emis is set to 1.0 on days with precipitation during months with predominately frontal storms (parameter tstorm $\mathbf{m o}=0$ ); or

emis is set proportionally to a value between 0.75 and 1.0 (U.S. Army, 1956) on days with precipitation during months with predominately convective storms (parameter tstorm_mo $=1$ ).

Outgoing long-wave radiation from the snowpack, which is assumed to behave as a perfect black body, is computed with equation $1-76$ by using the surface-layer temperature. The net long-wave radiation to the snowpack is calculated by subtracting the outgoing from the incoming (equation 1-77).

The combined energy term for convection and latent heat from condensation (cecsub) for each HRU are combined into the product of the parameter cecn_coef and the air temperature (temp, either tminc or tmaxc depending on whether the calculation is for the daylight or night period):

$$
\operatorname{cecsub}_{H R U}=\text { cecn_coef }_{\text {month }} \times t e m p_{H R U}
$$

Because vapor pressures need to be high for convection and condensation to be substantial, this energy is only applied when there is precipitation and the air temperature is above $0{ }^{\circ} \mathrm{C}$. To account for diminished wind, the energy applied is reduced by half in areas with shrub or tree land cover.

The total energy exchange at the snow-atmosphere interface is estimated by adding the shortwave radiation, net long-wave radiation, and convection/condensation terms. A positive value of total energy exchange indicates incoming energy at the snowpack surface. If the surface temperature is $0{ }^{\circ} \mathrm{C}$ and there is incoming energy from the atmospheric interface, then surface snow melts and this water transfers energy to the lower snowpack. Under these conditions, any energy from conduction is negligible compared to the transfer of energy from the melted snow. When the energy is applied to the snowpack, snowmelt occurs when the heat deficit is overcome and the threshold capacity for free-water storage (parameter freeh2o_cap) is exceeded.

All atmospheric energy, other than precipitation, can only affect the lower layer of snowpack when it is in an isothermal melt phase. When the snowpack is in accumulation phase, heat is transferred only by conduction between the lower layer and surface layer. Only the surface layer is assumed to exchange energy with the atmosphere. If the lower layer is warmer than the surface layer, then the loss of conducted energy can freeze free water in the lower layer and increase the heat deficit. If the lower layer is colder than the surface layer, then incoming conducted energy from the surface layer will decrease the heat deficit in the lower layer and possibly bring the entire snowpack to isothermal at $0{ }^{\circ} \mathrm{C}$.

While the temperature of the surface layer varies with the air temperature, the lower layer tends to integrate the energy exchanges over time, resulting in a reduced temperature range relative to the surface layer. The heat conducted between the upper and lower layers is a function of the temperature gradient and the thermal conductivity of the snow. An estimate for snowpack thermal conductivity can be calculated as function of snowpack density, where density is the ratio of the snowpack SWE to the depth of the snow. In general, the density of a snowpack tends to increase over time, and therefore the depth tends to decrease over periods without new snowfall. The decrease in the depth of the snowpack is determined as a function of current snowpack depth ( $p k \_$depth), initial density of new snow (parameter den_init), maximum density of the snowpack (parameter den_max), total current snowpack SWE (pkwater_equiv), amount of new snowfall (net_snow), and settling rate (parameter settle_const). Snowpack depth for each HRU is based on the following ordinary differential equation (Riley and others, 1973):

$$
\begin{aligned}
& \frac{d\left(p k \_ \text {depth } h_{H R U}\right)}{d t}+\text { settle_const } \times p k \_d e p t h_{H R U}= \\
& \quad \frac{n e t \_s n o w_{H R U}}{\text { den_init }}+\left(\text { settle_const } \times \frac{\text { pkwater_equiv } v_{H R U}+n e t \_s n o w_{H R U}}{\text { den_max }}\right) .
\end{aligned}
$$

An approximate numerical solution for the change in snow depth for each HRU over a finite time step $(t)$ can be calculated as follows: 


$$
\begin{gathered}
\Delta p k_{-} d e p t h_{H R U}=\Delta t \times\left(\frac{n e t \_s n o w_{H R U}}{\text { den_init }}\right)+ \\
\Delta t \times \text { settle_const } \times\left(\frac{p k w a t e r \_e q u i v_{H R U}+n e t \_s n o w_{H R U}}{\text { den_max }}-p k \_d e p t h_{H R U}\right) .
\end{gathered}
$$

The snowpack depth for each HRU is computed as the snowpack depth from the previous day $\left(p k \_d e p t h^{t-I}\right)$ plus the change computed with equation 1-80:

$$
p k \_d e p t h_{H R U}=p k \_d e p t h_{H R U}^{t-1}+\Delta p k \_d e p t h_{H R U} .
$$

After a new depth is computed, the new snowpack density ( $\left.p k \_d e n\right)$ is calculated as the SWE divided by the new depth:

$$
p k \_d e n_{H R U}=\frac{p k w a t e r \_e q u i v_{H R U}}{p k \_d e p t h} \text {. }
$$

Conducted heat (qcond) will be either to or from (positive or negative) the lower layer relative to the surface layer, and is estimated as a function of the snowpack density and temperature gradient between the surface and lower layer (temp-pk_temp) (Anderson, 1968):

$$
\text { qcond }_{H R U}=2 \times\left[0.5 \times p k_{-} d e n_{H R U} \sqrt{\frac{k e f f_{H R U} \times \Delta t}{0.5 \times p k_{-} d e n_{H R U} \times \dot{A}}}\right] \times\left(\text { temp }_{H R U}-p k_{-} \text {temp } p_{H R U}\right) \text {. }
$$

Both values of 0.5 in equation 1-83 are the specific heat of ice (in calories per cubic centimeter per degrees Celsius). This equation is computed twice for every day (daytime and night periods), so $\Delta t$ is 12 hours (hr). The effective thermal conductivity (keff) is computed as:

$$
k e f f_{H R U}=0.0077 \times\left(p k_{-} d e n_{H R U}\right)^{2}
$$

It is assumed that the conduction of heat is not a substantial source of energy for melting snow, so conducted heat does not generate snowmelt. However, conducted heat is important to proper simulation of temperature in the snowpack, and is capable of freezing free water in an isothermal $0{ }^{\circ} \mathrm{C}$ snowpack. Heat exchange with the snow-land interface is considered negligible relative to the interactions at the snow-atmosphere interface.

\section{Melt}

When the 12-hr energy balance (tcal) is negative, heat flow occurs by conduction only and the amount is computed by equation 1-83. When the 12-hr energy balance is positive, this energy is assumed to melt snow in the surface layer. Snowmelt transports heat into the lower layer by mass transfer. Snowmelt (snowmelt) for each HRU is computed as:

$$
\text { snowmelt }_{H R U}=\frac{\text { tcal }_{H R U}}{203.2} \times \text { snowcov_area }{ }_{H R U},
$$

where

203.2 is a constant equal to the number of calories required to melt 1 -inch of water-equivalent ice at $0{ }^{\circ} \mathrm{C}$, in calories per inch.

If the temperature of the lower layer ( $p k$ temp) is less than $0{ }^{\circ} \mathrm{C}$, then part or all of the snowmelt is refrozen. This heat is used to satisfy the heat deficit ( $\left.p k_{-} d e f\right)$ in the lower layer and a new snowpack temperature is computed by using 
equation 1-74. When the temperature of the lower layer reaches $0{ }^{\circ} \mathrm{C}$, any additional snowmelt is used to satisfy the free waterholding capacity (parameter freeh2o_cap). Once this capacity is satisfied, snowmelt leaves the snowpack and becomes infiltration and surface runoff.

\section{Sublimation}

Sublimation (snow_evap) can occur during periods of no transpiration for all HRUs, whereas sublimation can occur at any time in HRUs that are covered by grass or bare ground. Sublimation for each HRU is calculated as a fraction of the PET that evaporates from the snow-covered fraction of the HRU (snowcov_area):

$$
\text { snow_evap }{ }_{H R U}=\left(\text { potet_sublim } \times \text { potet }_{H R U} \times \text { snowcov_area }{ }_{H R U}\right)-h r u \_ \text {intcpevap }{ }_{H R U}
$$

Sublimation from intercepted snow (hru_intcpevap) is computed by the Interception Module and is not included in snow evap. Sublimated water is removed from the ice component of the snowpack. If the ice content of the snowpack is colder than the freezing point ( $p k$ temp less than $0{ }^{\circ} \mathrm{C}$ ), then sublimation will lower the heat deficit by an amount (scal) computed as:

$$
s c a l_{H R U}=p k_{-} \text {temp } p_{H R U} \times \text { snow_evap }{ }_{H R U} \times 1.27,
$$

where

1.27 is the specific heat of ice in calories per inch per square centimeter per degrees Celsius.

\section{Surface-Runoff Modules: srunoff_smidx and srunoff_carea}

The Surface-Runoff Modules compute surface runoff from infiltration excess and soil saturation by using a variable-sourcearea concept, where the runoff generating areas of the watershed surface vary in location and size over time (Dickinson and Whiteley, 1970; Hewlett and Nutter, 1970). Module srunoff_smidx computes these values by using a non-linear, variablesource-area method, whereas module srunoff_carea computes them by using a linear, variable-source-area method.

The user selects a Surface Runoff Module by setting control parameter srunoff_module in the Control File to either srunoff_carea or srunoff_smidx. Input parameters for the Surface Runoff modules are listed in table 1-3. Input and computed variables for these modules are listed in table 1-5.

Rain throughfall, snowmelt, and any cascading Hortonian surface runoff from an upslope HRU are partitioned to the pervious, impervious, and surface-depression storage portions of each HRU on the basis of the fraction of impervious area (parameter hru_percent_imperv) and surface-depression storage area (parameter dprst_area) of the HRU. Both modules compute retention storage, evaporation, and runoff on impervious and depression storage areas of each HRU by using continuity. Both modules compute seepage from surface-depression storage. Surface runoff due to infiltration excess and exceeding impervious storage capacity are summed and referred to as Hortonian surface runoff (Horton, 1933).

\section{Impervious Storage and Evaporation}

If the sum of rain throughfall, snowmelt, and the antecedent impervious storage (avail_water) exceeds retention storage capacity on the impervious portion of an HRU for a time step, impervious Hortonian surface runoff is generated. Water up to the impervious storage capacity (parameter imperv_stor_max) is retained until evaporated. Hortonian surface runoff from the impervious portion of an HRU ( $\left.h r u \_s r o f f i\right)$ for each time step is calculated from continuity according to:

$$
\text { avail_water }=\text { imperv_stor } t_{H R U}^{t-1}+\text { net_rain }_{H R U}+\text { snowmelt }_{H R U} .
$$
by:

If avail_water > imperv_stor_max $\mathbf{m}_{H R}$, then the impervious Hortonian surface runoff ( $\left.h r u \_s r o f f i\right)$ for an HRU is computed

$$
h r u_{-} r r o f f i_{H R U}=\left(\text { avail_water-imperv_stor_max } \mathbf{x}_{H R U}\right) \times \mathbf{h r u} \_ \text {percent_imperv } \mathbf{H R U}_{H},
$$


otherwise

$$
h r u \_s r o f f i_{H R U}=0.0 .
$$

Evaporation from the impervious portion of an HRU (hru_impervevap) for each time step is based on the available water and unsatisfied PET. Available water (avail_water) and unsatisfied PET (avail_et) are calculated according to:

$$
\begin{aligned}
& \text { avail_water }=\text { imperv_stor } r_{H R U}^{t-1}+\text { net_rain }{ }_{H R U}+\text { snowmelt }_{H R U}-\frac{h r u \_s r o f f i_{H R U}}{\text { hru_percent_imperv }}{ }_{H R U} \text { and } \\
& \text { avail_et }=\text { potet }_{H R U}-\text { snow_evap } p_{H R U}-h r u \_i n t c p e v a p_{H R U}-d p r s t \_e v a p \_h r u_{H R U},
\end{aligned}
$$

where

dprst_evap_hru $\quad$ is evaporation, in inches, from any surface-depression storage as computed in equation 1-112.

If avail_et is greater than or equal to avail_water, then the evaporation from the impervious portion for an HRU for each daily time step is computed by:

$$
h r u \_i m p e r v e v a p_{H R U}=a v a i l \_w a t e r \times\left(1-s n o w c o v \_a r e a_{H R U}\right) \times \mathbf{h r u} \_ \text {percent_imperv } \mathbf{H R U}_{\text {HRU }} .
$$

If avail_et is less than avail_water, then the evaporation from the impervious portion for an HRU for the time step is computed by:

$$
\text { hru_impervevap }{ }_{H R U}=\text { avail_et } \times\left(1-\text { snowcov_area } a_{H R U}\right) \times \mathbf{h r u} \_ \text {percent_imperv } \mathbf{H R U}_{\text {. }} .
$$

Storage on the impervious portion of an HRU is calculated from continuity for each daily time step according to:

$$
\begin{aligned}
& \text { hru_impervstor }{ }_{H R U}=h r u \_i m p e r v s t o r_{H R U}^{t-1}-h r u_{-} \text {Sroffi }_{H R U}-\text { hru_impervevap }_{H R U} \\
& +\left(\text { net_rain }_{H R U}+\text { snowmelt }_{H R U}\right) \times \text { hru_percent_imperv } \mathbf{H R U}_{H} \text {. }
\end{aligned}
$$

\section{Pervious Hortonian Surface Runoff and Infiltration}

Infiltration excess on the pervious portion of each HRU occurs when the throughfall, snowmelt, and any upslope Hortonian surface runoff available for infiltration exceed the capacity of the soil. The Hortonian surface runoff from the pervious portion of an HRU ( $\left.h r u \_s r o f f p\right)$ is calculated as:

$$
h r{ }_{-} \operatorname{sroff}_{H R U}=c a \_ \text {fraction } \times\left(\text { upslope_hortonian }{ }_{H R U}+\text { net_rain }_{H R U}+\text { snowmelt }_{H R U}\right),
$$

where

ca_fraction is the fractional variable-source area for the pervious portion of an HRU.

Module srunoff_carea computes ca_fraction on the basis of the antecedent (soil_rechr) and maximum (parameter soil_ rechr_max) soil-moisture content of the capillary reservoir recharge zone as:

$$
\text { ca_fraction }=\text { carea_min } \operatorname{miRU}_{H}+\left[\left(\text { carea_max }_{H R U}-\text { carea_min }_{H R U}\right) \times\left(\frac{\text { soil_rechr } r_{H R U}^{t-1}}{\text { soil_rechr_max }}\right)\right] \text {. }
$$


Module srunoff_smidx computes the antecedent soil-moisture content of the capillary reservoir (soil_moist) as:

$$
\begin{aligned}
& \text { avail_et }=\text { potet }_{H R U}-s n o w \_e v a p_{H R U}-h r u \_i n t c p e v a p_{H R U}-d p r s t \_e v a p \_h r u_{H R U} \text {, and } \\
& \text { ca_fraction }=\mathbf{s m i d x}_{-} \text {coef }_{H R U} \times(10)^{\text {smidx_exp }_{H R U} \times \text { smidx }} .
\end{aligned}
$$

If ca_fraction > carea_max $\mathbf{m}_{H R}$, then ca_fraction is set to carea_max $\mathbf{m}_{H R U}$.

When no snowpack exists, infiltration to the area association with pervious portion of an HRU is calculated as:

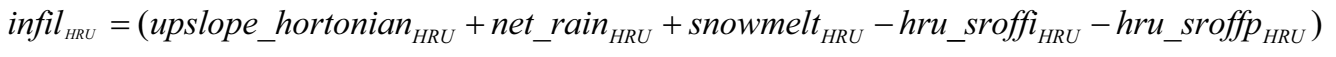

$$
\begin{aligned}
& \times\left(1-\text { hru_percent_imperv }{ }_{H R U}\right)
\end{aligned}
$$

If there is a snowpack, surface runoff on the pervious portion of the HRU and infiltration are adjusted on the basis of parameter snowinfil_max. First, the storage capacity deficit (capacity) of, available water for inflow (avail_water) to, and potential excess infiltration (excess) to the capillary reservoir are computed as:

$$
\begin{gathered}
\text { capacity }=\text { soil_moist_max } \mathbf{x}_{H R U}-\text { soil_moist }_{H R U}^{t-1}, \\
\text { avail_water }=\text { upslope_hortonian }_{H R U}+\text { snowmelt }_{H R U} \text {, and } \\
\text { excess }=\text { avail_water }- \text { capacity } .
\end{gathered}
$$

Second, any additional surface runoff (excess_infil) is computed as:

$$
\text { excess_infil }=\operatorname{MAX}\left(0.0, \text { avail_water }- \text { capacity }-\mathbf{s n o w i n f i l \_} \mathbf{m a x}_{H R U}\right) .
$$

If excess_infil is greater than 0.0, the value is added to hru_sroffp (equation 1-95) and the amount of water that infiltrates into the capillary reservoir for the HRU is set according to:

$$
\text { infil }_{H R U}=\text { snowinfil_max } \mathbf{m}_{H R U}+\text { capacity }_{H R U} .
$$

\section{Surface-Depression Simulation}

The Surface-Runoff Modules can simulate surface-depression processes that account for the effect of numerous, small, unregulated water bodies. Although the effect of an individual surface depression may be negligible, numerous surface depressions can have an effect on the hydrologic response of an HRU. Typically, surface depressions provide for water storage during and immediately after precipitation and snowmelt events; however, some may retain water year round. A surface depression is distinct from a lake in that it is not large enough to warrant discretization as its own HRU. Examples of surface depressions include prairie potholes, farm and mill ponds, and stormwater-retention structures. Specification of the control parameter dprst_ flag with the value 1 activates the surface-depression module.

The initial concept of surface depression, as implemented in PRMS, is described by Steuer and Hunt (2001). The first direct simulation of surface depressions within PRMS was described by Vining (2002). A subsequent implementation of surface depression simulation within PRMS was documented in Viger and others (2010).

Surface depressions that can generate surface runoff are called "open." Surface depressions that do not spill are called "closed." The maximum capacity of open surface depressions (dprst_vol_open_max) for each HRU is calculated according to: 


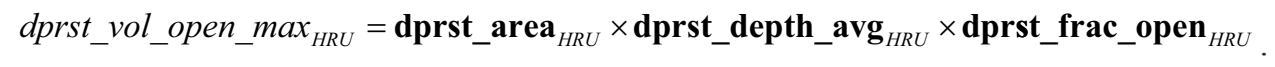

Closed surface depressions are simulated with unlimited storage capacity. Open surface depressions generate surface runoff when their storage reaches a threshold volume (dprst_vol_thres_open). Threshold volume for each HRU is computed according to:

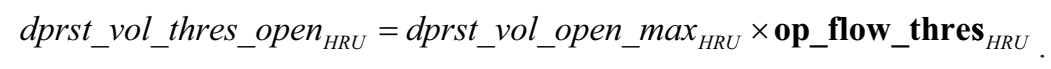

The initial amounts of water in open and closed surface depressions for each HRU are computed as:

$$
d p r s t \_v o l \_o p e n_{H R U}^{t=0}=\text { dprst_vol_open_max } \mathbf{x}_{H R U} \times \mathbf{d p r s t}_{-} \mathbf{f r a c} \_ \text {init }_{H R U}
$$

and

$$
\begin{aligned}
d p r s t \_v o l \_c l o s_{H R U}^{t=0}= & \text { dprst_area } \mathbf{A}_{H R U} \times \text { dprst_depth_avg }_{H R U} \times\left(1-\text { dprst_frac_open }_{H R U}\right) \\
& \times \text { dprst_frac_init }_{H R U}
\end{aligned}
$$

Values of open and closed storage volumes for subsequent time steps are computed on the basis of inflows and outflows and antecedent storage volumes. Cascading Hortonian surface runoff (upslope_hortonian), throughfall rain (net_rain) computed by the Interception Module, and snowmelt (snowmelt) computed by the Snow-Computation Module are added directly to open and closed surface depressions as depth, in inches, over the maximum area of the depressions. New storage volume in open depression storage for each HRU is calculated as:

$$
\begin{aligned}
& \text { dprst_vol_open }{ }_{H R U}=d p r s t \_v o l \_o p e n_{H R U}^{t-1}+ \\
& \left(\text { upslope_hortonian }_{H R U} \times \text { sro_to_dprst }_{H R U}+\text { net_rain }_{H R U}+\text { snowmelt }_{H R U}\right) \times d p r s t \_a r e a \_o p e n_{H R U}^{t-1} .
\end{aligned}
$$

The storage volume for closed surface depressions is calculated in the same manner by using the "_clos" versions of the variables in equation 1-109.

The surface area for open surface depressions for each HRU is calculated, according to Vining (2002) as:

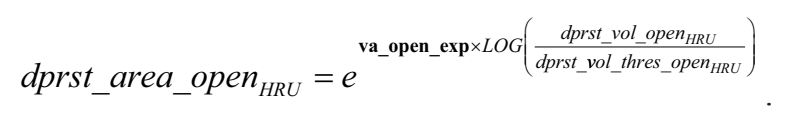

The surface area for closed surface depressions is calculated in the same manner using the "_clos" versions of the variables in equation 1-110.

Evaporation from both open and closed surface depressions is based on the PET. If a snowpack exists on an HRU, surfacedepression evaporation is reduced by the fraction of the HRU covered by snow. The maximum volume of surface-depression evaporation for each HRU is computed as:

$$
\begin{aligned}
d p r s t \_e v a p \_v o l \_\max _{H R U} & =\text { potet }_{H R U} \times\left(1-\text { snowcov_area }_{H R U}\right) \\
& \times\left(\text { dprst_area_open }{ }_{H R U}+d p r s t \_a r e a \_c l o s_{H R U}\right)
\end{aligned}
$$

The surface-depression evaporation is limited by the amount of PET used to satisfy evaporation from the canopy and sublimation from any snowpack. The actual evaporation from surface depressions (dprst_evap_vol) for each HRU is computed as:

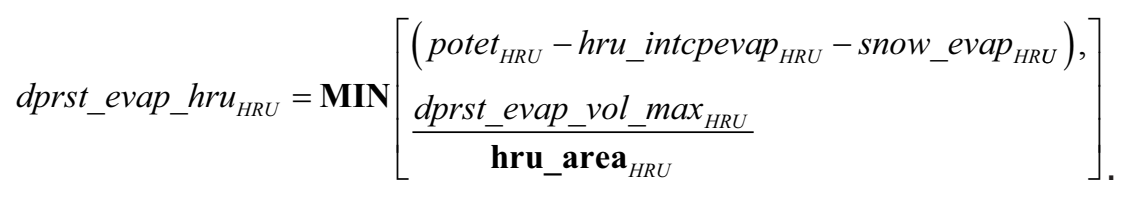


Losses from both open and closed surface depressions also include seepage to the groundwater reservoirs for each HRU and are computed as:

$$
\begin{aligned}
& d p r s t \_s e e p \_h r u_{H R U}=\frac{d p r s t \_v o l \_o p e n_{H R U} \times \mathbf{d p r s t} \_\mathbf{s e e p} \_r a t e \_o p e n_{H R U}}{\mathbf{h r u}_{-} \mathbf{a r e a} \mathbf{a}_{H R U}} \\
& +\frac{d p r s t \_v o l \_c l o s_{H R U} \times \text { dprst_seep_rate_clos }_{H R U}}{\text { hru_area }} \text {. }
\end{aligned}
$$

Any open surface depression that exceeds the maximum open storage volume for an HRU (equation 1-105) spills as surface runoff and is computed as:

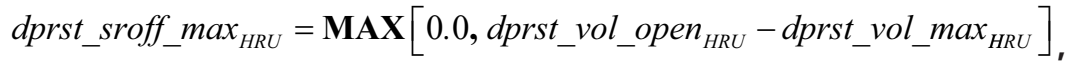

$$
\begin{aligned}
& d p r s t \_s r o f f \_t h r e S_{H R U}=\operatorname{MAX}\left[0.0, d p r s t \_v o l \_o p e n_{H R U}-d p r s t \_v o l \_t h r e s \_o p e n_{H R U}\right], \text { and } \\
& d p r s t \_s r o f f_{H R U}=d p r s t \_s r o f f \_m a x_{H R U}+\left(\text { dprst_flow_coef } \mathbf{C}_{H R U} \times d p r s t \_s r o f f \_t h r e s_{H R U}\right) .
\end{aligned}
$$

If dprst_sroff ${ }_{H R U}$ is greater than 0.0, then dprst_vol_open ${ }_{H R U}$ is reduced by this amount. The surface runoff from the surface depressions in each HRU is calculated as:

$$
d p r s t \_s r o f f \_h r u_{H R U}=\frac{d p r s t \_s r o f f_{H R U}}{\text { hru_area }_{H R U}} .
$$

The total Hortonian surface runoff for each HRU is calculated as:

$$
\text { hortonian_flow } w_{H R U}=d p r s t_{-} s r o f f \_h r u_{H R U}+h r u_{-} s r o f f p_{H R U}+h r u_{-} s r o f f i_{H R U} .
$$

\section{Soil-Zone Module: soilzone}

The soil-zone hydrologic processes are simulated by either the module soilzone or the combination of deprecated modules smbal_prms and ssflow_prms. The user has the option of setting control parameter soilzone_module in the Control File to soilzone or smbal_prms. Modules smbal_prms and ssflow_prms are only retained for backward compatibility with older PRMS applications. The remainder of this section describes the Soil-Zone Module. The smbal_prms and ssflow_ prms modules are documented by Leavesley and others (1996).

The input parameters used to compute soil-moisture and gravity-driven flow variables by the Soil-Zone module are defined in table 1-3. The input and computed variables are defined in table 1-5. Equation symbols, used in this section, correspond directly to PRMS-IV input or output, are defined in these two tables.

Computation of the water content of the soil zone is based on the summation of all moisture depletions and accretions. Depletions include evapotranspiration, drainage to the groundwater reservoir, fast and slow interflow, and saturation excess surface runoff (herein called Dunnian surface runoff) (Dunne and Black, 1970). Accretions are soil infiltration as computed by the Surface Runoff Module and any cascading Dunnian surface runoff and interflow from upslope HRUs as computed by the Soil-Zone Module. 


\section{Description of Conceptual Reservoirs}

The soil-zone module simulates three conceptual reservoirs. These reservoirs are the capillary reservoir, the gravity reservoir, and the preferential-flow reservoir (see fig. 2 of the body of this report). These three reservoirs are not physical layers in the soil column but rather represent, and account for, soil-water content at different levels of saturation. The water contained in each of these three reservoirs is subject to different physical processes and maximum storage capacities.

The capillary reservoir represents the water content between wilting point and field capacity (soil_moist) for each HRU with maximum content specified by parameter soil_moist_max. This reservoir occupies the fraction of the HRU that is pervious (hru_frac_perv). This water is held in place by capillary forces. It is not available for drainage and is depleted only through the process of evapotranspiration. As in previous versions of PRMS, the capillary reservoir is partitioned into two zones: the recharge zone and the lower zone. The recharge zone contains water (soil_rechr) with a maximum content specified by parameter soil_rechr_max. The water in this zone is available for evaporation and transpiration. Thus, it is the water content of the capillary reservoir that is available for direct evaporation at the land surface. The lower zone contains water (soil_lower) when the water-saturation level in the capillary reservoir exceeds soil_rechr_max. Thus, the maximum available water-holding capacity of the lower zone is the difference between soil_moist_max and soil_rechr_max. Lower-zone water is available only for transpiration.

Optionally, HRUs can include a preferential-flow reservoir when the preferential-flow density (parameter pref_flow_den) is specified greater than zero. The storage of this reservoir (pref_flow_stor) is limited to the water content between the preferential-flow threshold (pref_flow_thrsh) and total soil saturation (parameter sat_threshold). The threshold for each HRU is calculated as:

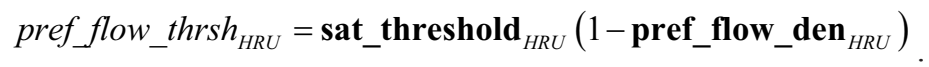

The maximum storage capacity in the preferential-flow reservoir for each HRU is calculated as:

$$
\text { pref_flow_max } \text { HRU }_{\text {S }}=\text { sat_threshold }_{H R U}-\text { pref_flow_thrsh } h_{H R U} \text {. }
$$

The storage of the gravity reservoir (slow_stor) is limited to the water-content between field capacity and pref_flow_thrsh. Water content in the gravity reservoir and preferential-flow reservoir (ssres_stor) is subject to the force of gravity, hydraulic conductivity, and storage capacity. Water content in the gravity reservoir is available for recharge to the groundwater reservoir, slow interflow, flow to the preferential-flow reservoir, and Dunnian surface runoff (see fig. 2 of the body of this report). Recharge from the gravity reservoir is conceptualized as vertical, gravity-driven flow through pore space within the soil. Slow interflow is conceptualized as lateral subsurface flow leaving the gravity reservoir. Dunnian surface runoff is conceptualized as excess soil water flowing downslope laterally on the land surface. Water in the preferential-flow reservoir is available for fast interflow and Dunnian surface runoff. Fast interflow is conceptualized as lateral subsurface flow through soil cracks, animal borrows, or leaf litter.

\section{Computation Order}

Table 1-6 describes the soil-water content at different levels of saturation in relation to the three soil-zone reservoirs and provides the sequence of steps for computations within the soil zone. This sequence is computed for each HRU according to the following steps. 
Table 1-6. Sequence of steps used in the computation of flow into and out of the soil zone.

[Input parameters are identified in bold, Times Roman font; computed variables and fluxes are identified in italic, Times Roman font; HRU, hydrologic response unit; GWR, groundwater reservoir; PFR, preferential-flow reservoir]

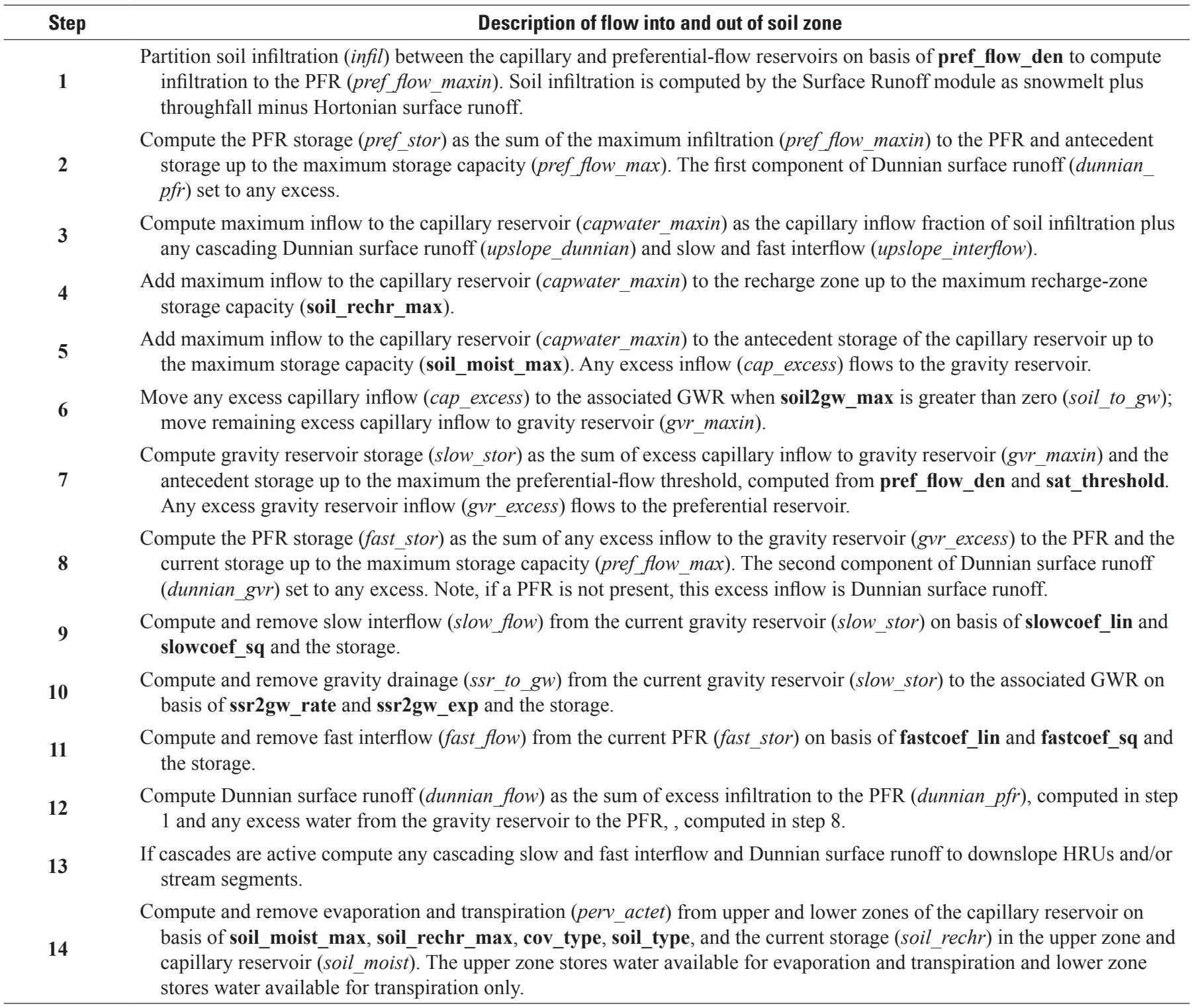




\section{Input to Storage Reservoirs}

\section{Step 1}

The amount of available water for input to the preferential-flow and capillary reservoirs is determined and then the fraction (parameter pref_flow_den) of soil infiltration (infil), as computed by the Surface-Runoff module, is apportioned to the preferential-flow reservoir as a maximum amount of water according to:

$$
\text { pref_flow_maxin }{ }_{H R U}=\text { infil }_{H R U} \times \text { pref_flow_den } \mathbf{n}_{H R U} \text {. }
$$

\section{Step 2}

This maximum amount of water is added to the antecedent preferential-flow reservoir storage up to the maximum storage capacity (equation 1-120) according to:

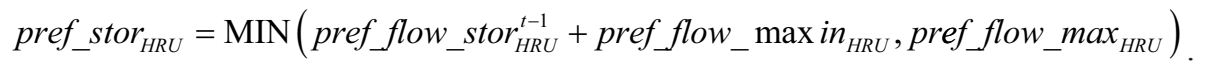

Any excess preferential-flow reservoir inflow is the first component of Dunnian surface runoff and is calculated according to:

$$
\text { dunnian_pfr } r_{H R U}=\mathbf{M A X}\left(0, \text { pref_flow_max } i n_{H R U}-\text { pref_flow_max }{ }_{H R U}\right) .
$$

\section{Step 3}

The remainder of the soil infiltration (infil) and any cascading Dunnian surface runoff (upslope_dunnianflow) and interflow (upslope_interflow) are added to the capillary reservoir according to:

$$
\begin{aligned}
& \text { capwater_maxin }_{H R U}=\frac{\text { upslope_dunnianflow } w_{H R U}+\text { upslope_interflow } w_{H R U}}{\text { hru_frac_perv } v_{H R U}}
\end{aligned}
$$

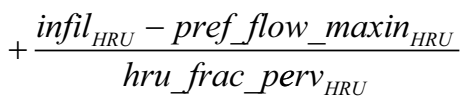

\section{Step 4}

The amount of capwater_maxin is added to the antecedent storage in the recharge zone (soil_rechr) of the capillary reservoir up to soil_rechr_max and is computed according to:

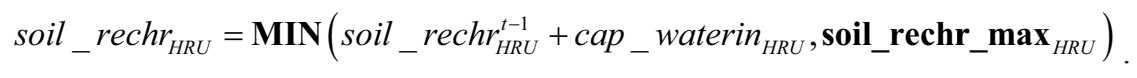

\section{Step 5}

The current storage in the capillary reservoir (soil_moist) is set to the sum of capwater_maxin and the antecedent storage in the soil-zone reservoir (soil_moist), up to soil_moist_max, and is computed according to:

$$
\text { soil_moist }_{H R U}=\operatorname{MIN}\left(\text { soil_moist }_{H R U}^{t-1}+\text { capwater_maxin }_{H R U}, \text { soil_moist_max } \operatorname{mRU}_{\text {HRU }}\right) .
$$

Storage in the lower zone, soil_lower, is set to the difference between soil_moist and soil_rechr according to:

$$
\text { soil_lower }{ }_{H R U}=\text { soil_moist }_{H R U}-\text { soil__echr }_{H R U} .
$$




\section{Step 6}

Excess inflow to the capillary reservoir (cap_excess) and infiltration (cap_waterin) to the capillary reservoir are calculated according to:

$$
\begin{aligned}
& \text { cap_excess }{ }_{H R U}=\mathbf{M A X}\left(0, \text { soil_moist }_{H R U}^{t-1}+\text { capwater_maxin }_{H R U}-\text { soil_moist_max } \mathbf{x}_{H R U}\right) \text { and }
\end{aligned}
$$

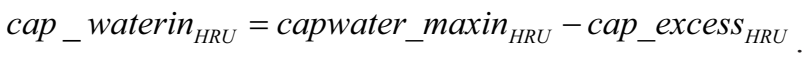

Any excess inflow to the capillary reservoir is first distributed to the groundwater reservoir (soil_to gw, is limited by a maximum recharge rate (parameter soil2gw_max) and calculated according to:

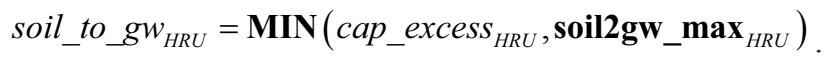

Any remaining excess is distributed to the gravity reservoir (gvr_maxin) and calculated according to:

$$
g v r_{-} \text {maxin }=\text { cap_excess }- \text { soil_to } \_g w_{H R U} \text {. }
$$

Step 7

Storage in the gravity reservoir is set to the sum of gvr_maxin and the antecedent of the storage (slow_stor), up to the maximum storage capacity of the gravity reservoir, and calculated according to:

$$
\text { grav_stor }_{H R U}=\mathbf{M I N}\left(\text { slow_stor } r_{H R U}^{t-1}+g v r_{-} \text {maxin, pref_flow_thrsh } h_{H R U}\right) .
$$

Excess flow (gvr_excess) and actual inflow (ssres_in) to the gravity reservoir are calculated according to:

$$
\begin{gathered}
\text { gvr_excess }=\mathbf{M A X}\left(0, \text { slow_stor }_{H R U}^{t-1}+g v r_{-} \text {maxin }- \text { pref_flow_thrsh } h_{H R U}\right) \text { and } \\
\text { ssres_in } n_{H R U}=g v r_{-} \text {maxin }-g v r_{-} \text {excess } .
\end{gathered}
$$

\section{Step 8}

Preferential-flow reservoir inflow (gvr_excess; equation 1-133) greater than the maximum storage capacity (equation 1-120) is the second component of Dunnian surface runoff and is computed according to:

$$
\text { dunnian_gvr }=\mathbf{M A X}\left(0, \text { fast_stor }_{H R U}+\text { pref_flow_max } i n_{H R U}-\text { pref_flow_max }{ }_{H R U}\right) .
$$

The remainder of the preferential-flow reservoir inflow ( $g v r 2 p f r)$ is added to the current storage (equation 1-122) and is calculated according to:

$$
\begin{gathered}
g v r 2 p f r_{H R U}=p f r \_f l o w \_\operatorname{maxin}_{H R U}-d u n n i a n \_g v r \text { and } \\
\text { pref2_stor } r_{H R U}=p r e f \_s t o r_{H R U}+g v r 2 p f_{H R U} .
\end{gathered}
$$




\section{Outflows from Soil-Zone Storage Reservoirs}

\section{Step 9}

There are four possible outflows from the soil zone: slow interflow, gravity drainage, Dunnian surface runoff, and fast interflow. Slow interflow occurs when the gravity-reservoir storage (equation 1-132) is greater than 0.0. The interflow equation is developed from continuity and an empirical relation (Leavesley and others, 1983; and Markstrom and others, 2008, p. 56-57). Slow interflow is computed and removed from the gravity-reservoir storage according to:

$$
\begin{gathered}
\text { slow_flow } w_{H R U}=\left(\text { slowcoef_lin }_{H R U} \times \text { grav_stor }_{H R U}\right)+\left(\text { slowcoef_sq }_{H R U} \times\left(\text { grav_stor }_{H R U}\right)^{2}\right) \text { and } \\
\text { grav2_stor }{ }_{H R U}=g r a v_{-} s t o r_{H R U}-s l o w \_f l o w_{H R U} .
\end{gathered}
$$

\section{Step 10}

Gravity drainage from the gravity reservoir is a function of the current storage and is computed and removed from the gravity-reservoir storage according to:

$$
\begin{gathered}
s s r_{-} t o \_g w_{H R U}=\mathbf{s s r 2} \mathbf{g w} \_\mathbf{r a t e}_{H R U} \times\left(g r a v 2 \_s t o r_{H R U}\right)^{\text {ssr2gw_exp }_{H R U}} \text { and } \\
\text { slow_stor }{ }_{H R U}=g r a v 2 \_s t o r_{H R U}-s s r_{-} t o \_g w_{H R U} .
\end{gathered}
$$

\section{Step 11}

Fast interflow is computed and removed from preferential-flow reservoir storage (equation 1-137) according to:

$$
\begin{gathered}
\text { fast_flow }_{H R U}=\left(\text { fastcoef_lin }_{H R U} \times \text { pref2_stor }_{H R U}\right)+\left(\text { fastcoef_sq }_{H R U} \times\left(\text { pref2_stor }_{H R U}\right)^{2}\right) \text { and } \\
\text { pref_flow_stor }{ }_{H R U}=p r e f 2_{-} \text {stor }{ }_{H R U}-\text { fast_flow }_{H R U} .
\end{gathered}
$$

\section{Step 12}

Any excess preferential-flow reservoir inflow (equation 1-135) plus excess infiltration (equation 1-123) is the total Dunnian surface runoff (dunnian_flow) and is calculated according to:

$$
\text { dunnian_flow }{ }_{H R U}=\text { dunnian_pfr }+ \text { dunnian_gvr } .
$$

\section{Step 13}

If the cascading flow procedure is active (see "Cascade Module" section in this appendix), interflow and Dunnian surface runoff are added to the capillary reservoir of any downslope HRUs according to:

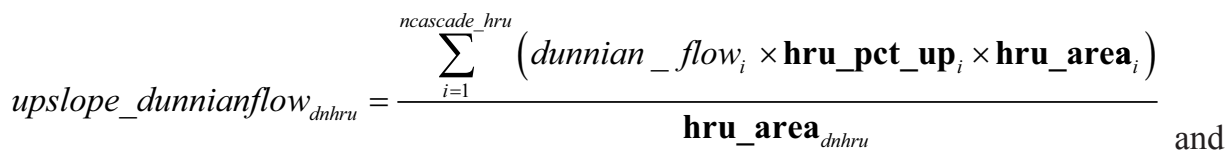




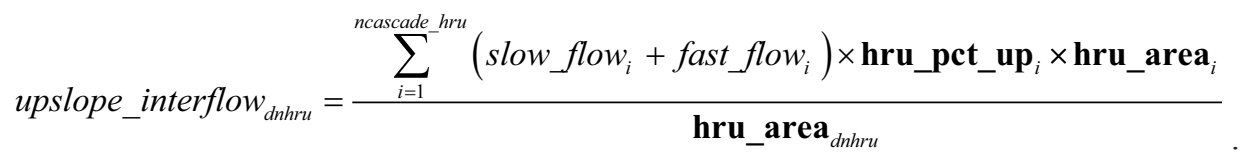

\section{Evapotranspiration from the Capillary Reservoir}

\section{Step 14}

Evapotranspiration from the capillary reservoir (perv_actet) depends on soil type (parameter soil_type), plant-cover type (parameter cov_type), snow-covered area (snowcov_area), and period of active transpiration (transp_on). If an HRU has 99 percent of its area covered by snow, then there is no evapotranspiration from the capillary reservoir. If an HRU is not in a period of active transpiration, then there is no transpiration, but there is evaporation. Evapotranspiration is limited by available water (soil_moist and soil_rechr) and remaining PET demand, which is computed according to:

$$
\begin{aligned}
& \text { avail_potet }_{H R U}=\text { potet }_{H R U}-\text { hru_intcpevap }{ }_{H R U}-\text { snow_evap }_{H R U}-\text { hru_impervevap } p_{H R U} \\
& \text {-dprst_evap_hru }
\end{aligned}
$$

Evapotranspiration is computed separately for the recharge and lower zones (Zahner, 1967; Leavesley and others, 1983, p. 22-23). Evapotranspiration in the recharge zone is based on a water-content ratio computed as:

$$
\text { soil_rechr_ratio }{ }_{H R U}=\frac{\text { soil_rechr } r_{H R U}}{\text { soil_rechr_max } \mathbf{x}_{H R U}} \text {. }
$$

If the soil in the HRU is predominantly sand (parameter soil_type $=1$ ), then there are two possible values for potet_rechr. If soil_rechr_ratio is less than 0.25 , then potet_rechr is set to $0 . \overline{5}$; otherwise, it is set to avail_et. If the soil in the HRU is predominantly loam (soil_type $=2$ ), then there are two possible values for potet_rechr. If soil_rechr_ratio is less than 0.5 , then potet_rechr is calculated according to:

$$
\text { potet_rechr } r_{H R U}=\text { soil_rechr_ratio }{ }_{H R U} \times \text { avail_potet } t_{H R U} .
$$

Otherwise, potet_rechr is set to avail_et. If the soil in the HRU is predominantly clay (soil_type $=3$ ), there are three possible values for potet_rechr. If soil_rechr_ratio is less than or equal to one-third, then potet_rechr is calculated according to:

$$
\text { potet_rech }_{H R U}=0.5 \times \text { soil_rechr_ratio }{ }_{H R U} \times \text { avail_potet } t_{H R U} \text {. }
$$

If soil_rechr_ratio is greater than or equal to two-thirds, then potet_rechr is set to avail_et. Otherwise, potet_rechr is set by using equation 1-149.

Evapotranspiration in the lower zone (potet_lower) is computed similarly (using equations 1-149 and 1-150) on the basis of a water-content ratio computed as:

$$
\text { lower_zone_ratio }{ }_{H R U}=\frac{\text { soil_moist } t_{H R U}}{\text { soil_moist_max } \mathbf{x}_{H R U}} \text {. }
$$

If potet_rechr is greater than or equal to potet_lower or the period of active transpiration is off, the evapotranspiration from the capillary reservoir (perv_actet) is set to potet_rechr. Otherwise, perv_actet is set to potet_lower. The water content of the recharge zone is reduced by potet_rechr. The water content of the capillary zone is reduced by pervactet. 


\section{Groundwater-Flow Module: gwflow}

The Groundwater-Flow Module (gwflow) simulates storage and inflows to and outflows from the groundwater reservoir (GWR). The GWR has infinite capacity and is the source of simulated baseflow. Applications developed with previous versions of PRMS typically used a single GWR for the entire domain. Applications developed with PRMS-IV should have a GWR corresponding to each HRU. Input parameters used to compute groundwater flow are defined in table 1-3. The input and computed variables are defined in table 1-5. All equation symbols used in this section are defined in these two tables.

Total inflow to each GWR (gwres_in) comes from excess soil water (equation 1-130), gravity drainage (equation 1-140), groundwater flow from any cascading upslope GWRs ( $g$ w_upslope), and from surface-depression storage seepage (equation 1-113) according to:

$$
g w r e s \_i n_{G W R}=s o i l \_t o \_g w_{G W R}+s s r \_t o \_g w_{G W R}+g w \_u p s l o p e_{G W R}+g w \_d p r s t \_s e e p_{G W R} .
$$

If control parameter strmflow_module is set to strmflow_lake, then seepage is computed as:

$$
\text { seepage }_{\text {lake }}=\left(\text { elevlake }_{\text {lake }}-\text { lake_seep_elev } \mathbf{l a k e}_{\text {lak }}\right) \times \text { gw_seep_coef }_{G W R} \text {. }
$$

There are two mechanisms by which water leaves a GWR: baseflow (gwres_flow) and the groundwater sink (gwres_sink). Baseflow is water that flows from a GWR to a stream segment, lake, or another GWR within the model domain, and is computed as:

$$
\text { gwres_flow } w_{G W R}=\text { gwflow_coef }_{\text {GWR }} \times \text { gwres_stor }_{\text {GWR }} \text {. }
$$

The groundwater sink represents groundwater flow that leaves the domain and is computed as:

$$
\text { gwres_sink } k_{G W R}=\text { gwsink_coef }_{G W R} \times \text { gwres_stor }_{G W R} \text {. }
$$

Storage in a GWR (gwres_stor) is computed from the inflows and outflows (equations 1-152-1-155) and the groundwater storage from the previous time step according to:

$$
\text { gwres_stor }{ }_{G W R}=g w r e s \_s t o r_{G W R}^{t-1}+g w r e s \_i n_{G W R}-g w r e s \_f l o w_{G W R}-g w r e s \_s i n k_{G W R}-\text { seepage }_{\text {lake }}^{t-1} .
$$

\section{Streamflow Modules}

Streamflow is computed by one of three user-specified options. The simplest approach is the strmflow module that calculates total streamflow leaving the domain as the sum of surface runoff, interflow, and groundwater discharge that reaches the stream network. The muskingum module uses a Muskingum flow-routing method to compute streamflow to and from individual stream segments. The strmflow_in_out module uses the same stream network as the muskingum module, but sets the outflow of each segment to the inflow. The user selects a Streamflow Module by setting control parameter strmflow_module in the Control File to one of three module names: strmflow, muskingum, or strmflow_in_out.

\section{strmflow}

The Streamflow Module sums flow (surface runoff, interflow, and groundwater discharge) from the HRUs and GWRs to calculate total streamflow out of the domain. There are no input parameters to the strmflow module. Input and computed variables are defined in table 1-5. Total streamflow out of the watershed, in inch-acres per day (basin_stflow) is computed as:

$$
\text { basin_stflow }=\text { basin_sroff }+ \text { basin_ssflow }+ \text { basin_gwflow . }
$$




\section{muskingum}

The Muskingum module was originally developed for PRMS by Mastin and Vaccaro (2002) and developed further by Markstrom (2012). The stream network used for Muskingum routing is conceptualized as a single-direction sequence of connected stream segments as specified by parameter tosegment. Typically, one segment is associated with each one-plane HRU or the pair of left- and right-bank HRUs, as specified by parameter hru_segment. This module has been modified from past versions (module musroute, Mastin and Vaccaro, 2002) to make it more stable for stream network routing in watersheds with stream segments with varying travel times. The Muskingum module has an internal structure that allows for a different computational time step for each segment within each PRMS daily time step. Flow values computed at these finer time steps are aggregated for each segment. The input parameters used by the Muskingum module to compute flow are defined in table 1-3. The input and computed variables are defined in table 1-5. All equation symbols used in this section are defined in these two tables.

The Muskingum routing equation (Linsley and others, 1982) assumes a linear relation between storage and the characteristics of the inflow (seg_inflow) and outflow (seg_outflow). Storage (storage) in a stream segment, for internal time step $\Delta t$, is computed as:

$$
\begin{aligned}
& \text { storage }_{\text {segment }}^{t}=\mathrm{k} \_ \text {coef }_{\text {segment }} \\
& \times\left(\left(\mathrm{x} \_ \text {coef }_{\text {segment }} \times s e g \_ \text {inflow } w_{\text {segment }}^{t}\right)+\left(1-\mathrm{x} \_ \text {coef }_{\text {segment }}\right) \times s e g \_ \text {outflow } w_{\text {segment }}^{t}\right) .
\end{aligned}
$$

Assuming that the average flow during an internal time step is equal to the average flow at the start and end times of the internal time step, the continuity equation can be expressed as:

$$
\begin{aligned}
\Delta \text { storage }_{\text {segment }}^{t}= & \text { storage }_{\text {segment }}^{t}-\text { storage }_{\text {segment }}^{t-1}= \\
& \left(\frac{\text { seg_inflow }_{\text {segment }}^{t}+s e g \_ \text {inflow } w_{\text {segment }}^{t-1}}{2}\right) \times \Delta t_{\text {segment }} \\
& -\left(\frac{s e g \_o u t f l o w_{\text {segment }}^{t}+s e g \_o u t f l o w_{\text {segment }}^{t-1}}{2}\right) \times \Delta t_{\text {segment }} .
\end{aligned}
$$

Substituting equation 1-156 into equation 1-157 and solving for the stream-segment outflow, for the internal time step, results in:

$$
\begin{aligned}
\text { seg_outflow } w_{\text {segment }}^{t} & =\left(c 0_{\text {segment }} \times s e g \_i n f l o w_{\text {segment }}^{t}\right)+\left(c 1_{\text {segment }} \times s e g \_ \text {inflow } w_{\text {segment }}^{t-1}\right) \\
& +\left(c 2_{\text {segment }} \times s e g \_o u t f l o w_{\text {segment }}^{t-1}\right)
\end{aligned},
$$

where

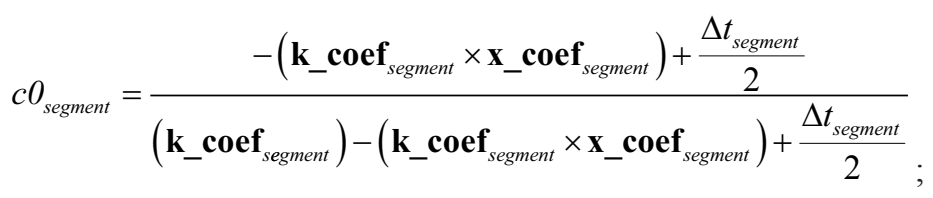

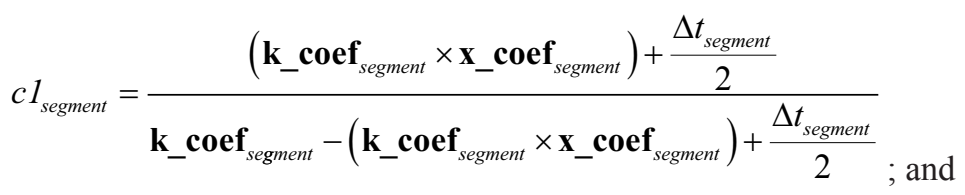




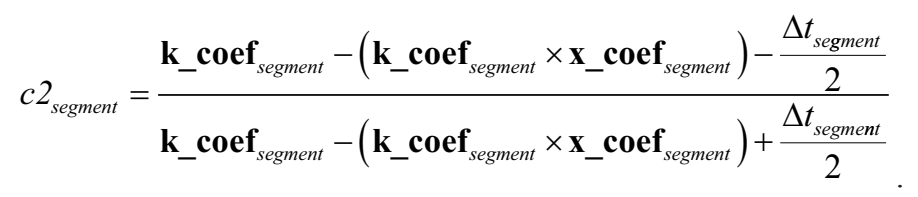

The internal time step $(\Delta t)$ used in equations 1-159-1-163 is calculated by the Muskingum module for each stream segment according to:

$$
\Delta t_{\text {segment }}=\left\lfloor\frac{24}{\left[\frac{24}{\left\lfloor\mathbf{k}_{-} \text {coef }_{\text {segment }}\right\rfloor}\right]}\right\rfloor \text {, }
$$

which is the travel time, in hours, rounded down to an even divisor of 24 hours (for example, 24, 12, 6, 4, 3, 2, and 1). PRMS-IV is restricted to daily time steps, so travel time, in hours, can never be greater than 24 . This means that the travel time of any segment in the stream network (parameter K_coef) must be less than one day. An implication of equation 1-164 is that the routed streamflow in each segment can be computed by using different internal time steps. Consequently, streamflow must be aggregated when flowing from segments with shorter $\Delta t$ to segments with longer $\Delta t$. Likewise, streamflow must be disaggregated when flowing from segments with longer $\Delta t$ to shorter $\Delta t$.

\section{strmflow_in_out}

The strmflow_in_out module uses the same stream network as the muskingum module, but directly sets the outflow of each segment to be the sum of the inflows. The input parameters used by the strmflow_in_out module to compute flow are defined in table 1-3. The input and computed variables are defined in table 1-5. The Muskingum equations (equations 1-158-1-164) are not solved by the strmflow_in_out module so that the parameters K_coef and $\mathbf{x} \_$coef are ignored.

\section{strmflow_lake}

Lakes can have major effects on streamflow. In this report, any water bodies that occupy an entire HRU are referred to as lakes (parameter hru_type $=2$ ). Lakes are assumed to have constant surface area (parameter hru_area). Ice cover, snowpack accumulation, and snowpack melt on lake surfaces are not simulated; however, any falling snow is added to the lake storage. Control parameter strmflow_module is used to select the strmflow_lake module. The strmflow_lake module uses the same stream network as the muskingum module. Input parameters used by the strmflow_lake module are defined in table 1-3. The input and computed variables are defined in table 1-5. All equation symbols used in this section are defined in these two tables.

The lake identification number with each HRU is specified by parameter lake_hru. More than one HRU can be associated with a lake. The dimension nlake specifies the total number of lakes. This module provides six simulation options to compute and route flow through lakes: (1) modified Puls; (2) linear; (3) flow through; (4) hydraulic approximation of natural flow through broad-crested weirs as a function of lake-surface elevation; (5) flow-through gates using rating tables and time series of gateheight openings; and (6) setting the stream outflow equal to the measured flow at a streamflow gage. Selection of the computation method for each lake is specified using parameter lake_type.

If modified Puls routing (parameter lake_type $=1$ ) is specified for a lake, the dimension mxnsos specifies the maximum number of storage/outflow values in all Puls rating tables. The modified Puls routing method is described by the U.S. Soil Conservation Service (1971). Depletions from lakes include evaporation and streamflow. Inflows include precipitation, streamflow, and any cascading surface runoff and interflow from neighboring HRUs.

The linear storage routing method (lake_type $=2$ ) is based on the equations:

$$
\begin{aligned}
\text { lakein }_{\text {lake }}= & \text { lake_precip } p_{\text {lake }}+\text { lake_stream_in } n_{\text {lake }}+\text { lake_sroff } f_{\text {lake }}+\text { lake_interflow }{ }_{\text {lake }} \text {, } \\
& + \text { lake_seep_in lake }
\end{aligned},
$$




$$
\begin{aligned}
& \text { avin }_{\text {lake }}=\left(\text { lakein }_{\text {lake }}+\text { lakein }_{\text {lake }}^{t-1}\right) \times 0.5 \text {, and } \\
& \frac{d\left(\text { lake_stor }_{\text {lake }}\right)}{d t}=\text { avin }_{\text {lake }}-\left(\text { lake_coef } \mathbf{l a k e}_{\text {lake }} \times \text { laker }_{\text {lake }}\right) .
\end{aligned}
$$

Solving this equation for lake storage from the previous time step (lake_stor lake) using the linear routing coefficient (lake_coef), a time step of one day in duration, and substituting into the continuity equation, lake outflow is computed as:

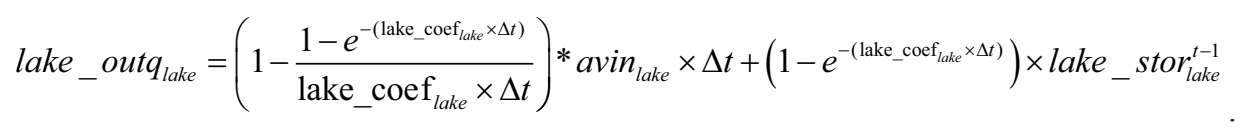

If flow through routing (lake_type $=3$ ) is specified for a lake, then the outflow is equal to the inflow:

$$
\text { lake_outq }{ }_{\text {lake }}=\text { lakein }_{\text {lake }} \text {. }
$$

Two methods provide for simulation of regulated and unregulated outflow from lakes based on lake-surface elevation, storage, and allowing for lakebed permeability. These methods are (1) hydraulic approximation of natural flow through a broadcrested weir (lake_type $=4$ ) and (2) flow through gates using a user-specified rating table (lake_type $=5$ ). Depletions include evaporation, streamflow, and lakebed seepage. Inflows include precipitation, streamflow, and groundwater discharge, as well as any cascading surface runoff and interflow (equation 1-165). Groundwater discharge and lakebed seepage are computed as a function of water-surface elevation. Dudley (2008) describes these methods as applied in the Denny's River, Maine. Broadcrested weir flow is computed as:

$$
\text { lake_outq } \text { lake }=\left(\text { elevlake } e_{\text {lake }}\right)^{1.5} \times \text { weir_coef }_{\text {lake }} \times \text { weir_len }_{\text {lake }} \text {. }
$$

If outflow from the lake is determined using rating tables (lake_type $=5$ ), up to four rating tables can be specified. The time series of gate opening heights (gate_ht) for each rating table are specified in the Data File. Each rating table specifies the lake elevations and corresponding gate openings. Dimensions nstage, ngate, nstage2, ngate2, nstage3, ngate3, nstage4, and ngate4 are used to specify the rows and columns of each rating table.

Also, this option allows for the possibility of a second outflow from these lakes that is removed from the model domain. However, the second outflow remains in the code for downward compatibility of an existing model (Dudley, 2008) and is planned to be removed in future versions of PRMS. The second outflow is a linear function of the lake-surface elevation (elevlake) and two flow coefficient parameters (lake_out2_a and lake_out2_b) that is computed as:

$$
s c n d \_c f s_{\text {lake }}=\left(\text { lake_out2_a } \mathbf{a}_{\text {lake }} \times \text { elevlake } \text { lake }\right)-\text { lake_out2_b } \mathbf{b}_{\text {lake }} \text {. }
$$

For lake_type $=4$ or 5, seepage (seepage) is computed by the Groundwater Flow Module (equation 1-153).

Time series values (runoff) from the Data File can be used to specify lake outflow directly (lake_type =6). Parameter obsout_lake associates a lake to a column in the Data File. This method does not preserve a water balance and is typically used for calibration downstream from regulated lakes.

\section{Summary Modules}

The summary modules provide summaries of selected variables at different spatial and temporal resolutions. The four summary modules are basin_sum, subbasin, and map_results. The four Temperature-Distribution Modules included in PRMS-IV are temp_1sta, temp_2sta_prms (deprecated), temp_laps, and temp_dist2. Module temp_2sta_ prms is only retained for backward compatibility with older PRMS applications. 


\section{basin_sum}

Module bas in_sum writes to the Water-Budget File specified by control parameter model_output_file. This file is described in Appendix 2; section "Output Files." This module produces summaries for the domain on daily, monthly, yearly, and the total simulation period on the basis of the values of parameters print_type and print_freq. Input parameters and input and computed variables for module bas in_sum are listed in table 1-3 and table 1-5, respectively.

Three types of reports are available: (1) Discharge reports (parameter print_type $=0$ ) that describe measured and simulated streamflow; (2) Water-balance reports that include precipitation, evapotranspiration, storage, and simulated and measured streamflow data (parameter print_type =1); and (3) Detailed reports that include temperature, solar radiation, and input, output, and storage results (parameter print_type $=2$ ). The content of these reports is summarized in table 1-7.

Table 1-7. Summary fields for Model Output Report File produced by the basin_sum module.

The frequency of output is specified by parameter print_freq-daily (print_freq = 8), monthly (print_freq = 4), yearly $($ print_freq $=2)$, total $($ print_freq $=1)$ simulation time, or any additive combination. Table 1-8 shows a sequence of summary reports that would be typical for a watershed modeler completing an initial setup and manual calibration.

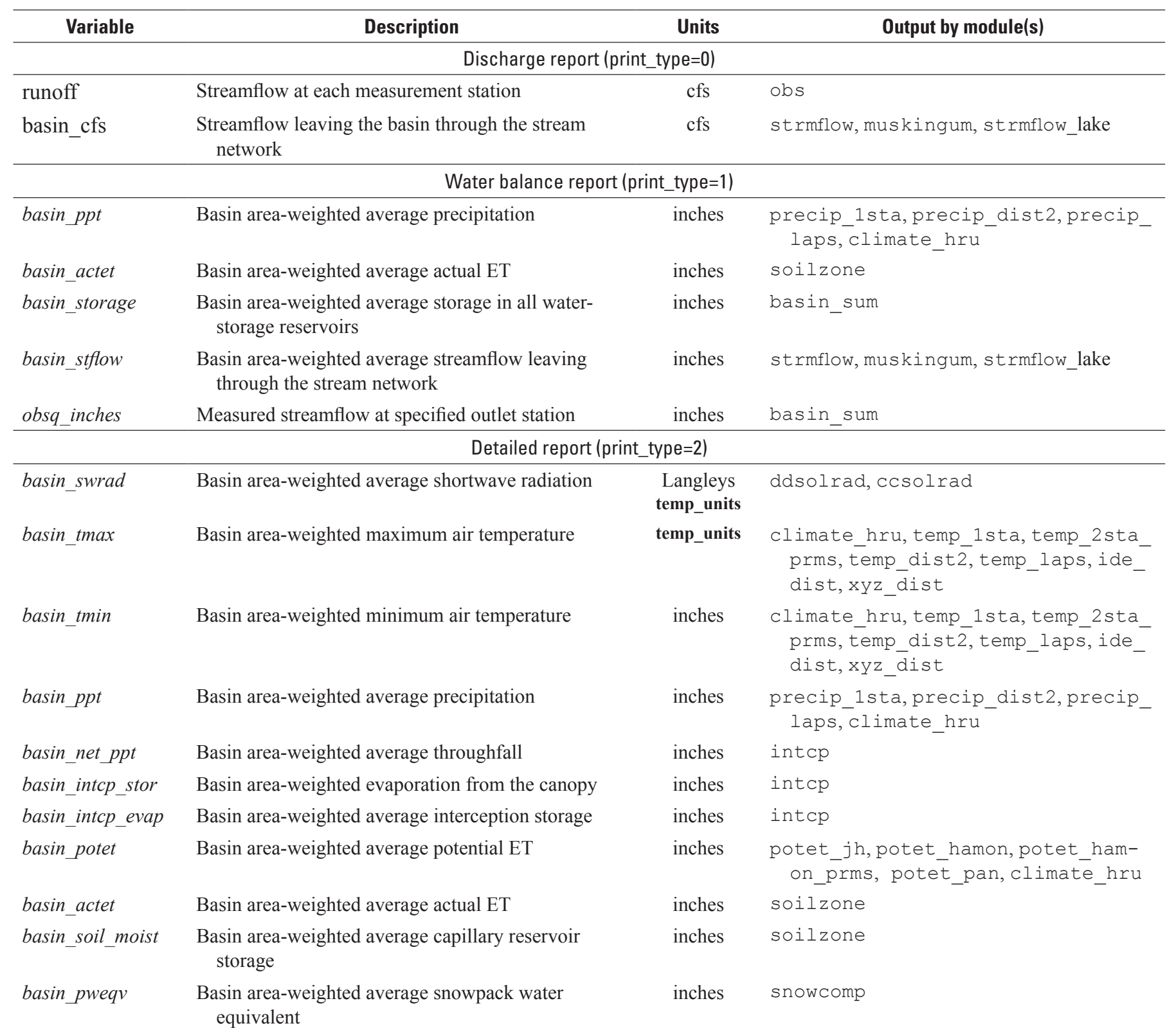


Table 1-7. Summary fields for Model Output Report File produced by the basin_sum module._Continued

The frequency of output is specified by parameter print_freq—daily (print_freq = 8), monthly (print_freq = 4), yearly $($ print_freq $=2)$, total $\left(\mathbf{p r i n t} \_\right.$freq $\left.=1\right)$ simulation time, or any additive combination. Table 1-8 shows a sequence of summary reports that would be typical for a watershed modeler completing an initial setup and manual calibration.

\begin{tabular}{|c|c|c|c|}
\hline Variable & Description & Units & Output by module(s) \\
\hline basin_snowmelt & Basin area-weighted average snowmelt & inches & snowcomp \\
\hline basin_gwstor & Basin area-weighted average storage in GWRs & inches & gwflow \\
\hline basin_gwflow & $\begin{array}{l}\text { Basin area-weighted average groundwater flow to the } \\
\text { stream network }\end{array}$ & inches & gwflow \\
\hline basin_sroff & $\begin{array}{l}\text { Surface runoff leaving the basin through the stream } \\
\text { network }\end{array}$ & inches & srunoff_carea, srunoff_smidx \\
\hline basin_stflow & $\begin{array}{l}\text { Basin area-weighted average streamflow leaving } \\
\text { through the stream network }\end{array}$ & inches & strmflow, muskingum, strmflow_lake \\
\hline
\end{tabular}

Table 1-8. Typical sequence of output reports viewed during manual calibration exercise.

[ET, evapotranspiration]

\begin{tabular}{ccl}
\hline & \\
0 & 4 & Monthly summaries of measured versus simulated streamflow for the basin. \\
1 & 4 & Monthly report of basin area-weighted average precipitation, actual ET, and streamflow. \\
2 & 4 & Detailed report of air temperature, precipitation, actual ET, streamflow, snowpack, snowmelt, and state variables. \\
1 & 15 & Daily, monthly, yearly, and run summaries of basin area-weighted average precipitation, actual ET, and streamflow. \\
\hline
\end{tabular}

\section{subbasin}

The Subbasin Module provides a method to divide the domain into groups of HRUs called subbasins (parameter hru_subbasin). Each HRU can only be assigned to one subbasin. This module computes summaries of streamflow and other variables that can be used for calibration. Streamflow at the outlet of a subbasin is the sum of the components of flow generated by the HRUs and GWRs contained in that subbasin. In addition, this streamflow contributes to the streamflow of any subbasin designated as being downstream (parameter subbasin_down). The subbasin module is active if the dimension nsub is specified greater than 0 and the control parameter subbasin_flag $=1$. Input parameters used by the subbasin module are defined in table 1-3. The input and computed variables are defined in table 1-5.

\section{map_results}

The Map Results Module (map_results) facilitates loosely coupling PRMS-IV with other models. The module summarizes simulated results into the spatial and temporal resolutions required by the coupled model. It writes results for each HRU in a gridded format summarized at four temporal scales - weekly, monthly, yearly, and the total simulation time period. Summarized results can be written in the units of the output variable or converted from inches per day to either feet per day, centimeters per day, or meters per day. The map_results module is active when the control parameter mapOutON_OFF $=1$. The input parameters used in the module are defined in tables 1-3. 
Four parameters are specified in the Parameter File to control the map results module computations. The parameter mapvars_units specifies the output units. If the value of mapvars_units is specified as 0 , the output units remain unchanged. If the value of the parameter mapvars_units is specified as 1,2, or 3, the units of each output variable must be inches per day. The parameter ncol specifies the number of columns for each row of the mapped results. If the value of ncol is not an even divisor of dimension nhru, the last line will have fewer than ncol number of values.

The parameter prms_warmup specifies the number of years the simulation will execute prior to computing summarized results. For example, if the simulation start date (control parameter start_time) is specified to be 10/1/1980, the end date (control parameter end_time) is specified to be 9/30/1996, and parameter prms_warmup is specified to be 2, then map_results computations begin on 10/1/1982. For this example, the first monthly results will be for October 1982, and the last monthly results will be for September 1996; yearly results will be for the 14 water years 1983 through 1996 (where a water year extends from October 1 of the previous calendar year to September 30 of the water year of interest). Total results will be the average of the 14 water years. If a user wants results for calendar years, the simulation start time should be specified with a start day of January 1.

Summaries of gridded results are written to one or more Map-Results Files as time series of selected variables averaged over the temporal frequency (or frequencies) selected, as specified by parameter mapvars_freq. Results can be written for average weekly rates (output file 'variable_name.weekly'); monthly rates (output file 'variable_name.monthly'), average yearly rates (output file 'variable_name.yearly'), and(or) the average rate over the total simulation period (output file 'variable_name. total'). The prefix "variable_name" of each output file is the name of each variable specified by control parameter mapOutVar_ names. Separate output files are written for each variable to the PRMS-IV execution directory. The number of output variables is specified by control parameter nmapOutVars. Figure 1-6 shows an example of the control parameters required to use the map_results module:

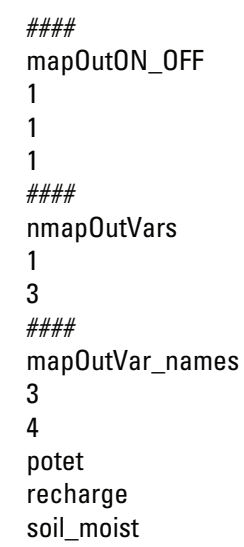

Any variable dimensioned by nhru, ngw, or nssr shown in table 1-5 can be output to a Map Results File. The module distributes simulated results from an HRU map to a target map by using an area-weighted scheme based on three topological parameters, specified in the Parameter File, that are determined on the basis of the intersection of the HRU map and target map. These topological parameters are: gvr_hru_id, gvr_cell_id, and gvr_cell_pct, the associated HRU identification number, the associated target map spatial unit identification number, and the associated fraction of the target-map spatial unit, respectively, of each intersection. These topological parameters are named on the basis of the USGS coupled Groundwater and Surface-Water Flow Model (GSFLOW), as described on pages 25-27 and tables 1-25 of the GSFLOW documentation report (Markstrom and others, 2008). Two dimensions are associated with these parameters, nhrucell and ngwcell, the number of intersections between the HRU map and target map and the number of spatial units in the target map, respectively.

The HRU map and target map can be of different spatial extents. For example, the target map can extend beyond the HRU map or be fully or partially coincident with the HRU map (Markstrom and others, 2008, fig. 16). If the HRU map and the target map are the same (dimensions ngwcell $=\mathbf{n h r u}$ ), then the mapping is one to one, that is, 1.0 is specified for all values of parameter gvr_cell_pet. In this case, if there are 40 HRUs and the user specifies 4 as the value of ncol, the output will be a grid that has 10 rows and 4 columns; HRU 1 would correspond to row 1, column 1 and HRU 40 would correspond to row 10, column 4.

Groundwater-recharge estimates computed by PRMS have been loosely coupled to MODFLOW (Harbaugh, 2005) models in various applications (see Bjerklie and others, 2010; Jeton and Maurer, 2007; Lee and Risley, 2002; Steuer and Hunt, 2001; Vaccaro, 1992; and Vaccaro, 2007). The map_results module can facilitate this by summarizing values of recharge, computed by the soil zone module, to the MODFLOW finite-difference grid map. These values can be used as initial estimates of the infiltration at land surface (defined by using variable "FINF" in the Unsaturated-Zone Flow Package; Niswonger and others, 2006). These groundwater recharge estimates do not reflect interactions with the underlying unsaturated and saturated zones that would be calculated by an integrated GSFLOW simulation. 


\section{References Cited}

Anderson, E.A., 1968, Development and testing of snow pack energy balance equations: Water Resources Research, v. 4, no. 1, p. $19-38$.

Anderson, E.A., 1973, National Weather Service river forecast system-Snow accumulation and ablation model: NOAA Technical Memorandum NWS Hydro-17, U.S. Department of Commerce, Silver Spring, Md., p. 3-7.

Bauer, H.H., Vaccaro, J.J., 1987, Documentation of a deep percolation model for estimating ground-water recharge: U.S. Geological Survey Open-File Report 86-536, 180 p.

Bjerklie, D.M., Starn, J.J., and Tamayo, Claudia, 2010, Estimation of the effects of land use and groundwater withdrawals on streamflow for the Pomperaug River: U.S. Geological Survey Scientific Investigations Report 2010-5114, 81 p.

Brinkman, W.A.R., 1979, Growing season length as an indicator of climatic variations: Climatic Change, v. 2, p. 127-138.

Christiansen, D. E., Markstrom, S. L., and Hay, L. E., 2011, Impacts of climate change on growing season in the United States: Earth Interactions, v. 15, no. 33, p. 1-17.

Cooter, E.J., and LeDuc, S.K., 1995, Recent frost date trends in the north-eastern USA: International Journal of Climatology, v. 15 , p. $65-67$.

Dean, J.D., and Snyder, W.M., 1977, Temporally and areally distributed rainfall: Journal of Irrigation Division A.S.C.E., TA 103, no. 1R2, p. 221-224.

Dickinson, W.T., and Whiteley, H.Q., 1970, Watershed areas contributing to runoff: International Association of Hydrologic Sciences Publication 96, p. 1.12-11.28.

Dudley, R.W., 2008, Simulation of the quantity, variability, and timing of streamflow in the Dennys River Basin, Maine, by use of a precipitation-runoff watershed model: U.S. Geological Survey Scientific Investigations Report 2008-5100, 37 p., at http://pubs.usgs.gov/sir/2008/5100/.

Dunne, T., and Black, R.G., 1970, An experimental investigation of runoff production in permeable soils: Water Resources Research, v. 6, p. 478-490.

Federer, A.C., and Lash, D., 1978, Brook, A hydrologic simulation model for eastern forests: Durham, N. H., University of New Hampshire, Water Resources Research Center, Research Report No. 19, 84 p.

Ford, L.R., and Fulkerson, D.R., 1956, Maximal flow through a network: Canadian Journal of Mathematics, v. 8, p. 399-404.

Frank, E.C., and Lee, R., 1966, Potential solar beam irradiation on slopes: U. S. Department of Agriculture, Forest Service Research Paper RM-18, 116 p.
Hamon, W.R., 1961, Estimating potential evapotranspiration: Proceedings of the American Society of Civil Engineers, Journal of the Hydraulic Division, v. 87, no. HY3, p. $107-120$.

Harbaugh, A.W., 2005, MODFLOW-2005, the U.S. Geological Survey modular ground-water mode-The GroundWater Flow Process: U.S. Geological Survey Techniques and Methods 6-A16, variously paginated.

Hargreaves, G.H., and Allen, R.G., 2003, History and evaluation of Hargreaves evapotranspiration equation: Journal of Irrigation and Drainage Engineering, v. 129, no. 1, p. 53-63.

Hargreaves, G.H., and Samani, Z.A., 1985, Reference crop evapotranspiration from temperature: Applied Engineering in Agriculture, v. 1, no. 2, p. 96-99.

Hay, L.E., and Clark, M.P., 2003, Use of statistically and dynamically downscaled atmospheric model output for hydrologic simulations in three mountainous basins in the western United States: Journal of Hydrology, v. 282, p. 56-75.

Hay, L.E., Clark, M.P., Wilby, R.L., Gutowski, W.J., Leavesley, G.H., Pan, Z., Arritt, R.W., and Takle, E.S., 2002, Use of regional climate model output for hydrologic simulations: Journal of Hydrometeorology, v. 3, p. 571-590.

Hay, L.E., and McCabe, G.J., 2002, Spatial variability in water-balance model performance in the conterminous United States: Journal of the American Water Resources Association, v. 38, no. 3, p. 847-860.

Hay, L.E., Wilby, R.L., and Leavesley, G.H., 2000, A comparison of delta change and downscaled GCM scenarios for three mountainous basins in the United States: Journal of the America Water Resources Association, v. 36, p. 387-397.

Hay, L.E., Clark, M.P. Pagowski, M., Leavesley, G.H., and Gutowski, W.J., Jr., 2006a, One-way coupling of an atmospheric and a hydrologic model in Colorado: Journal of Hydrometeorology, v. 7, no. 4, p. 569-589.

Hay, L.E., Leavesley, G.H., and Clark, M.P., 2006b, Use of remotely-sensed snow covered area in watershed model calibration for the Sprague River, Oregon: Joint Federal Interagency Sedimentation Conference, 8th, and Federal Interagency Hydrologic Modeling Conference, 3rd, Reno, Nev., April 2-6, 2006, Proceedings: Advisory Committee on Water Information, accessed August 17, 2011at http://acwi.gov/hydrology/mtsconfwkshops/conf_ proceedings/3rdFIHMC/third_fihmc_nevada-2006.pdf.

Hay, L.E., Leavesley, G.H., Clark, M.P., Markstrom, S.L., Viger, R.J., and Umemoto, M., 2006c, Step-wise, multipleobjective calibration of a hydrologic model for a snowmeltdominated basin: Journal of the American Water Resources Association, p. 877-890. 
Henson, W.R., Medina, R.L., Niswonger, R.G., and Regan, R.S., 2013, CRT - Cascading Routing Tool to define flow paths for grid-based watershed models: U.S. Geological Survey Techniques and Methods 6-D2, p. 28.

Hewlett, J.D., and Nutter, W.L., 1970, The varying source area of streamflow from upland basins, in Proceedings of the symposium on interdisciplinary aspects of watershed management: Bozeman, Mont., Montana State University, p. 65-83. [August 3-6, 1970]

Horton, R.E., 1933, The role of infiltration in the hydrological cycle: American Geophysical Union Transactions, v. 23, p. $479-482$.

Irmak, Suat, Kabenge, Isa, Skaggs, K.E., and Mutiibwa, Denis, 2012, Trend and magnitude of changes in climate variables and reference evapotranspiration over 116-yr period in the Platte River Basin, central Nebraska-USA: Journal of Hydrology, v. 420-421, p. 228-244.

Jensen, M.E., and Haise, H.R., 1963, Estimating evapotranspiration from solar radiation: Proceedings of the American Society of Civil Engineers, Journal of Irrigation and Drainage, v. 89 , p. $15-41$.

Jensen, M.E., Rob, D.C.N., and Franzoy, C.E., 1969, Scheduling irrigations using climate-crop-soil data, Proceedings: New Orleans, La., National Conference on Water Resources Engineering of the American Society of Civil Engineers, p. 20.

Jeton, A.E., and Maurer, D.K., 2007, Precipitation and runoff simulations of the Carson Range and Pine Nut Mountains, and updated estimates of ground-water inflow and the ground-water budget for basin-fill aquifers of Carson Valley, Douglas County, Nevada, and Alpine County, California: U.S. Geological Survey Scientific Investigations Report 2007-5205, 56 p., at http://pubs.usgs.gov/sir/2012/5205/.

Kunkel, K.D., Easterling, R., Hubbard, K., and Redmond, K., 2004, Temporal variations in frost-free season in the United States - 1895-2000: Geophysics Research, Letters, v. 31, no. L03201, doi: 10.1029/2003GL018624.

Leaf, C.F., 1966, Free water content of snowpack in subalpine areas, in Western Snow Conference, Seattle, Wash., April 19-21, 1966, Proceedings: Soda Springs, Calif., Western Snow Conference, v. 34, p. 17-24.

Leaf, C.F., and Brink, G.E., 1973, Hydrologic simulation model of Colorado subalpine forest: U.S. Department of Agriculture, Forest Service Research Paper RM-107, 23 p.

Leavesley, G.H., Lichty, R.W., Troutman, B.M., and Saindon, L.G., 1983, Precipitation-runoff modeling system-User's manual: U.S. Geological Survey Water-Resources Investigations Report 83-4238, $207 \mathrm{p}$.
Leavesley, G.H., Restrepo, P.J., Markstrom, S.L., Dixon, M.J., and Stannard, L.G., 1996, The Modular Modeling System (MMS) - User's manual: U.S. Geological Survey Open-File Report 96-151, $142 \mathrm{p}$.

Leavesley, G.H., and Striffler, W.D., 1978, A mountain watershed simulation model, in Colbeck, S.C., and M. Ray, eds., Modeling of snow cover runoff, Hanover, N.H., Proceedings: U.S. Army Corps of Engineers, Cold Regions Research and Engineering Laboratory, p. 379-386.

Lee, K.K., and Risley, J.C., 2002, Estimates of groundwater recharge, base flow, and stream reach gains and losses in the Willamette River Basin, Oregon: U.S. Geological Survey Water-Resources Investigations Report 01-4215, 52 p.

Linsley, R.K., Kohler, M.A., and Paulhus, J.L., 1982, Hydrology for engineers: New York, McGraw-Hill, p. 508.

Lu, Jianbiao, Sun, Ge, McNulty, S.G., and Amatya, D.M., 2005, A comparison of six potential evapotranspiration methods for regional use in the southeastern United States: Journal of the American Water Resources Association, v. 41, no. 3, p. 621-633.

Markstrom, S.L., 2012, P2S - Coupled simulation with the Precipitation-Runoff Modeling System (PRMS) and the Stream Temperature Network (SNTemp) Models: U.S. Geological Survey Open-File Report 2012-1116, 19 p., at http:// pubs.usgs.gov/of/2012/1116/.

Markstrom, S.L., Niswonger, R.G., Regan, R.S., Prudic, D.E., and Barlow, P.M., 2008, GSFLOW-Coupled groundwater and surface-water flow model based on the integration of the Precipitation-Runoff Modeling System (PRMS) and the Modular Groundwater Flow Model (MODFLOW-2005): U.S. Geological Survey Techniques and Methods 6-D1, $240 \mathrm{p}$.

Mastin, M.C., and Vaccaro, J.J., 2002, Documentation of Precipitation Runoff Modeling System modules for the Modular Modeling System modified for the Watershed and River Systems Management Program: U.S. Geological Survey Open-File Report 2002-362, 5 p.

Meeus, J., 1999, Astronomical algorithms: Richmond, Va., Willmann-Bell, Inc., 477 p.

Miller, D.H., 1959, Transmission of insolation through pine forest canopy as it effects the melting of snow: Mitteilungen der Schweizerischen Anstalt für das forstliche Versuchwesen, v. 35 , p. $35-79$.

Monteith, J.L., 1965, Evaporation and environment, in The state and movement of water in living organisms: Symposia for the Society of Experimental Biology, v. 19, p. 205-234.

Murray, F.W., 1967, On the computation of saturation vapor pressure: Journal of Applied Meteorology, v. 6, p. 203-204. 
Niswonger, R.G., Prudic, D.E., and Regan, R.S., 2006, Documentation of the Unsaturated-Zone Flow (UZF1) Package for modeling unsaturated flow between the land surface and the water table with MODFLOW-2005: U.S. Geological Survey Techniques and Methods, book 6, chap. A19, 62 p.

Obled, C.H., and Rosse, B.B., 1977, Mathematical models of a melting snowpack at an index plot: Journal of Hydrology, v. 32, p. 139-163.

Penman, H.L., 1948, Natural evaporation from open water, bare soil and grass: Proceedings of the Royal Society of London, England, series A, v. 193, p. 120-145.

Priestley, C.H.B., and Taylor, R.J., 1972, On the assessment of the surface heat flux and evaporation using large-scale parameters: Monthly Weather Review, v. 100, no. 2, p. 81-92.

Riley, J.P., Israelsen, E.K., and Eggleston, K.O., 1973, Some approaches to snowmelt prediction, in The role of snow and ice in hydrology: International Association of Hydrological Sciences Publication 107, p. 956-971.

Steuer, J.J., and Hunt, R.J., 2001, Use of a watershed-modeling approach to assess hydrologic effects of urbanization, North Fork Pheasant Branch basin near Middleton, Wisconsin: U.S. Geological Survey Water-Resources Investigations Report 2001-4113, 49 p.

Swift, L.W., Jr., 1976, Algorithm for solar radiation on mountain slope: Water Resources Research, v. 12, no. 1, p. 108-112.

Tangborn, W.V., 1978, A model to predict short-term snowmelt runoff using synoptic observations of streamflow, temperature, and precipitation, in Modeling of Snow Cover Runoff: Hanover, N. H., U.S. Army Corps of Engineers, Cold Region Research Laboratory, p. 414-426.

Thompson, E.S., 1976, Computation of solar radiation from sky cover: Water Resources Research, v. 12, no. 5, p. 859-865.

Thornton, P.E., Thornton, M.M., Mayer, B.W., Wilhelmi, N., Wei, Y., Cook, R.B., 2012, Daymet: Daily surface weather on a $1 \mathrm{~km}$ grid for North America, 1980-2011: Oak Ridge, Tenn., Oak Ridge National Laboratory Distributed Active Archive Center, doi:10.3334/ORNLDAAC/Daymet_V2, accessed November 11, 2014, at http://daymet.ornl.gov/.

Thornton, P.E., Running, S.W., and White, M.A., 1997, Generating surfaces of daily meteorology variables over large regions of complex terrain: Journal of Hydrology, v. 190, p. 214-251.

U.S. Army, 1956, Snow hydrology: Portland, Oreg., U.S. Army Corps of Engineers, North Pacific Division, 437 p.
U.S. Army Corps of Engineers, 1987, Corps of Engineers wetlands delineation manual: U.S. Army Corps of Engineers Technical Report Y-87-1, variously paginated.

U.S. Department of Agriculture National Agricultural Statistics Service (NSS), 1999, Grain, hay, potato, cotton, soybean, and tobacco, production by state, 1998, in R. Famighetti, ed., 2000 World Almanac and Book of Facts: Mahwah, N.J., Primedia Reference.

U.S. Geological Survey, 2000, U.S. GeoData Digital Elevation Models: U.S. Geological Survey Fact Sheet 040-00, 4 p., at http://pubs.er.usgs.gov/usgspubs/fs/fs04000.

U.S. Soil Conservation Service, 1971, SCS national engineering handbook, Section 4-Hydrology: Washington, D.C., U.S. Government Printing Office, 654 p.

Vaccaro, J.J., 1992, Sensitivity of groundwater recharge estimates to climate variability and change, Columbia Plateau, Washington: Journal of Geophysical Research, v. 97, no. D3, p. 2,821-2,833.

Vaccaro, J.J., 2007, A deep percolation model for estimating ground-water recharge-Documentation of modules for the modular modeling system of the U.S. Geological Survey: U.S. Geological Survey Scientific Investigations Report 2006-5318, 30 p.

Viger, R.J., Hay, L.E., Jones, J.W. and Buell, G.R., 2010, Accounting for large numbers of small water bodies in the application of the Precipitation-Runoff Modeling System in the Flint River Basin, Georgia: U.S. Geological Survey Open-File Report 2010-5062, 37 p.

Vining, K.C., 2002, Simulation of streamflow and wetland storage, Starkweather Coulee subbasin, North Dakota, water years 1981-98: U.S. Geological Survey Water-Resources Investigations Report 02-4113, 28 p.

Vézina, P.E., and Péch, G.Y., 1964, Solar radiation beneath conifer canopies in relation to crown closure: Forest Science, v. 10, no. 4, p. 443-451.

Wang, J.Y., 1963, Agricultural meteorology: Frederick, Md., Pacemaker Press, 693 p.

Zahner, Robert, 1967, Refinement in empirical functions for realistic soil-moisture regimes under forest cover, in Sopper, W.E., and Lull, H.W., eds., International Symposium of Forest Hydrology: New York, Pergamon Press, p. 261-274. 


\section{Appendix 2. PRMS-IV Users' Guide}

\section{Contents}

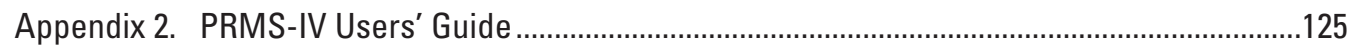

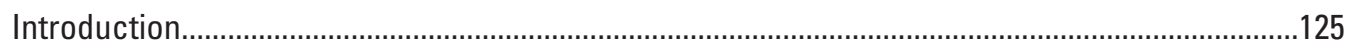

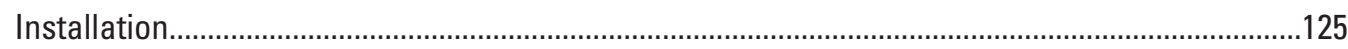

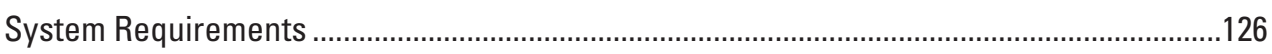

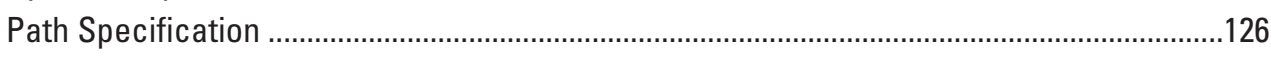

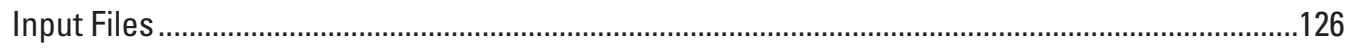

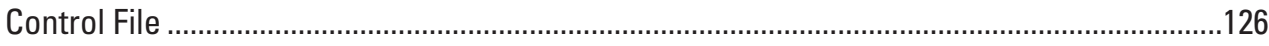

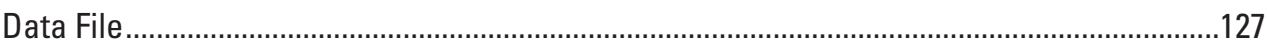

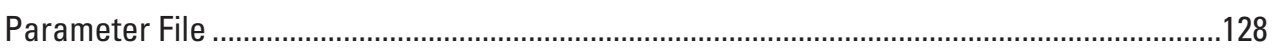

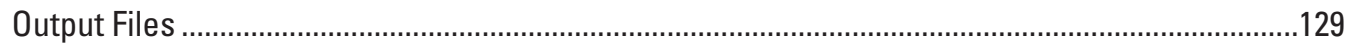

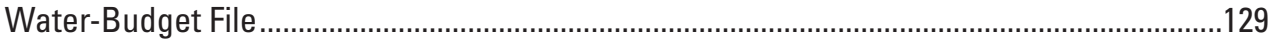

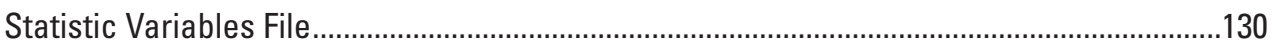

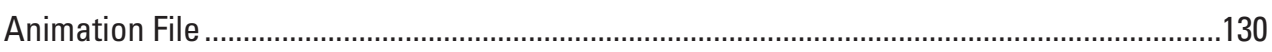

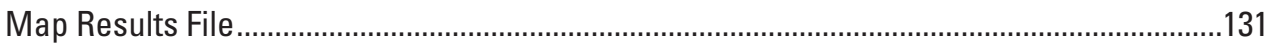

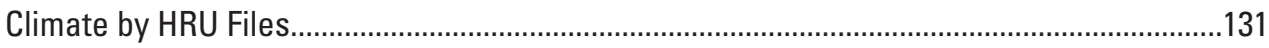

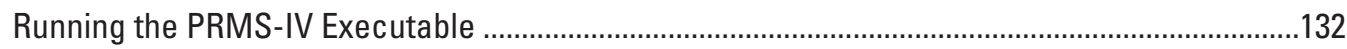

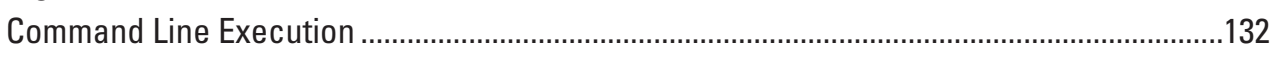

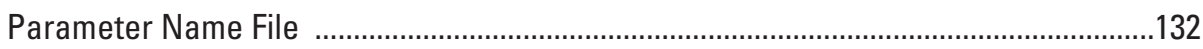

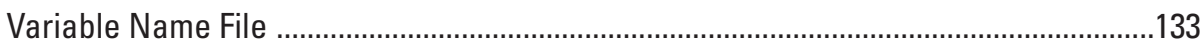

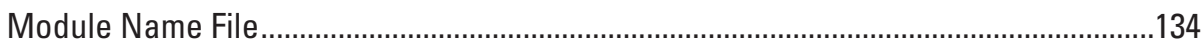

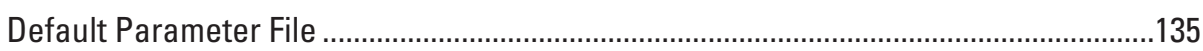

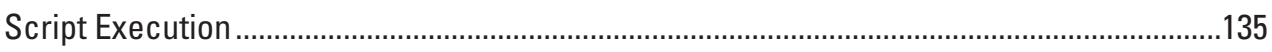

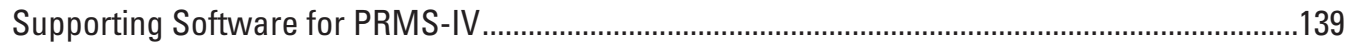

References Cited.................................................................................................................

\section{Figures}

2-1. Precipitation-Runoff Modeling System distribution directory structure

2-2. The first 22 lines of an example Control File. Only 4 control parameters (aniOutON_OFF, aniOutVar_names, ani_output_file, and data_file) are shown. Note that the line numbers are not part of the Control File but are included here for reference purposes..

2-3. Lines from an example Data File. The header and only three lines of data are shown. Note that the line numbers are not part of the Data File but are included here for reference purposes.

2-4. Selected lines of an example Parameter File. The header and parts of the dimensions and parameters sections are shown. Note that the line numbers are not part of the Parameter File but are included here for reference purposes. 
2-5. Selected lines of an example Water-Budget File. The header and table sections are shown. Note that the line numbers are not part of the Water-Budget File, but are included here for reference purposes

2-6. Selected output from a Statistic Variables (statvar) File that lists simulated (basin_cfs) and measured (runoff) streamflow. The header and data sections are shown

2-7. Selected output from an example of an Animation File that lists snowpack-water equivalent, soil moisture, evapotranspiration, and precipitation for each hydrologic response unit. The header and data sections are shown 130

2-8. Selected output from an example of a Map Results File that lists yearly output of recharge values for a 6 -by 5 -grid

2-9. Selected output from an example of a Map Results File that lists total simulation period output of recharge values for a 6 -by- 5 grid.

2-10. Selected output from an example of a Climate by hydrologic response unit (HRU) (CBH). File containing precipitation data (precip) for five HRUs

2-11. Selected lines of an example Parameter Name File. The header, dimensions, and parameters sections are shown. Note that the line numbers are not part of the Parameter Name File but are included here for reference purposes

2-12. Selected lines of an example Variable Name File. The header and variables sections are shown. Note that the line numbers are not part of the Variable Name File but are included here for reference purposes

2-13. Selected lines of an example Module Name File. The header and modules sections are shown. Note that the line numbers are not part of the Module Name File but are included here for reference purposes

2-14. Example of a Linux Korn shell script that runs the Precipitation-Runoff Modeling System (prms) executable 21 times with nested loops

2-15. Screen image showing Precipitation-Runoff System running inside of the Object User Interface (from Markstrom and Koczot, 2008)...

2-16. Screen image showing Precipitation-Runoff Modeling System running inside of Luca (from Hay and Umemoto, 2007)

2-17. Screen image showing the Downsizer (from Ward-Garrison and others, 2009) 


\section{Appendix 2. PRMS-IV Users' Guide}

\section{Introduction}

This appendix serves as the Users' Guide for the Precipitation-Runoff Modeling System, version 4 (PRMS-IV). It includes installation instructions, description of input and output files, and guidelines for running the executable on the Windows and Linux operating systems.

\section{Installation}

PRMS-IV is available from the U.S. Geological Survey PRMS software web page (http://water.usgs.gov/lookup/ get? crresearch/prms, accessed January, 2014) and is distributed as a Windows zip file or Linux archive file. About 200 megabytes of disk space is required for installation and example projects.

The PRMS-IV distribution is installed into a directory named prmsIV $\backslash$ (fig. 2-1). Five subdirectories are located within this directory. The directories: (1) bin $\backslash$ contains the PRMS executable, (2) doc $\backslash$ contains a copy of this report and includes any errata or documentation updates, (3) lib \contains the compiled libraries necessary to run PRMS-IV and associated tools, (4) projects $\backslash$ contains the files for the examples, and (5) src $\backslash$ contains the source code.

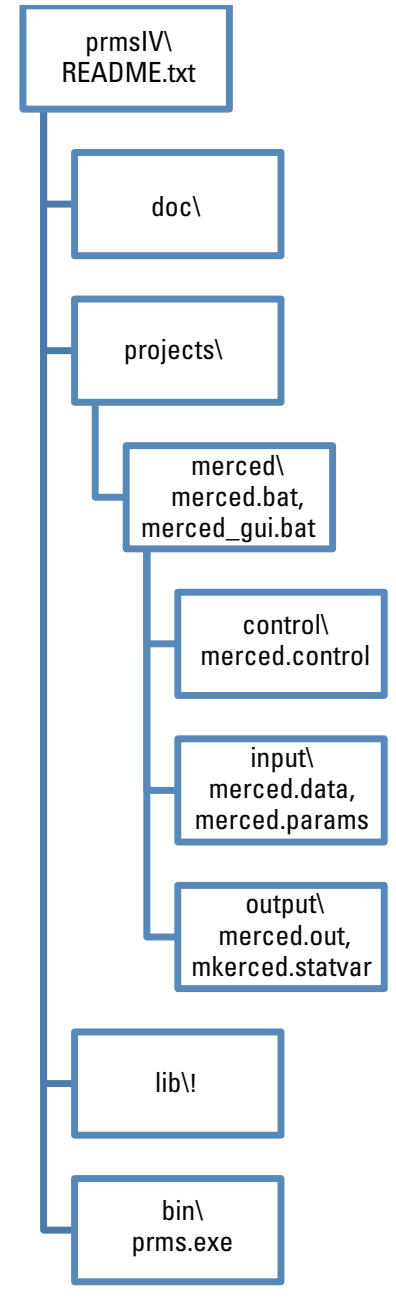

Figure 2-1. Precipitation-Runoff Modeling System distribution directory structure. 


\section{System Requirements}

PRMS-IV is distributed for Windows- and Linux-based personal computers. Minimum system requirements include use of Windows 7, Windows XP, or the Linux operating system; 800 megahertz Intel Pentium III processor (or equivalent); 8 megabytes random access memory; and 1 gigabyte of hard disk space. For instance, the Merced River basin example in Appendix 3 was developed on a Windows 7 personal computer with an AMD 3000+ Athlon processor, 2 gigabytes of random-access memory, and 60 gigabytes of hard disk space. PRMS-IV installation on other computer operating systems can require platformdependent modifications.

The PRMS-IV executable requires installation of no additional software. Several of the associated graphical user interfaces and tools require a third-party software package. The Object User Interface (Markstrom and Koczot, 2008) and Luca (Hay and Umemoto, 2007) both require Java version 7 or later (http://java.com, accessed January, 2014). The GIS Weasel (Viger and Leavesley, 2007) requires the Environmental Systems Research Institute Workstation software (http://www.esri.com, accessed April, 2012).

\section{Path Specification}

Paths may be specified as either relative or absolute. There are two locations in a PRMS-IV project where paths are specified (1) the PRMS-IV Control File and (2) executable script files, such as the acf.bat for the Windows distribution. All relative path specifications are made to the directory where the model is run. All path specifications in the example projects included with the distribution are relative and need not be edited.

\section{Input Files}

This section describes the input file requirements for a PRMS-IV simulation. The Control File, Data File, and Parameter File are based on the Modular Modeling System (MMS) input file formats (Leavesley and others, 1996).

\section{Control File}

The Control File contains all of the control parameters that PRMS-IV uses during the course of the simulation (see table 1-2 in Appendix 1 for a description of PRMS-IV control parameters). There are five basic types of control parameters specified in this file: (1) those related to model execution, (2) those related to model input, (3) those related to model output, (4) those related to initial conditions, and (5) those related to specification of the active modules. Specifically, the Control File is used to specify input and output file names, content of the input and output files, simulation starting and ending dates, and the active modules.

A Control File consists of a header line (fig. 2-2, line 1) followed

1. PRMS Control File

2. \#\#\#

3. aniOutON_OFF // Set this to 1 to

4. 1 print Animation File, 0 to turn off.

5. 1

6. 0

7. \#\#\#

8. aniOutVar_names

9. 3

10. 4

11. pkwater_equiv

12. soil_moist

13. hru_actet

14. \#\#\#

15. ani_output_file

16. 1

17. 4

18. ./output/animation.out

19. \#\#\#\#

20. data_file

21. 1

22. 4

23. ./input/data by a sequence of control-parameter items. Each line in the Control File can include descriptive text to allow annotation of any data (fig. 2-2, line 3). The descriptive text is added to lines following the required data and preceded by at least one space and two forward slashes (//). Each line in the Control File can be up to 256 characters.

Figure 2-2. The first 22 lines of an example Control File. Only 4 control parameters (aniOutON_OFF, aniOutVar_names, ani_output_file, and data_file) are shown. Note that the line numbers are not part of the Control File but are included here for reference purposes. 
Control-parameter items consist of four lines followed by parameter values, one per line, that have a standard structure and order. The first line (fig. 2-2, line 2) is used as a delimiter, signifying the start of a control-parameter item, and must specify a string of four pound signs (\#\#\#\#) beginning in column 1. The second line (fig. 2-2, line 3) specifies the name of the control parameter. The third line (fig. 2-2, line 4) specifies the number of parameter values that are specified. The fourth line (fig. 2-2, line 5) identifies the data type of the control parameter by using an integer flag. Valid values are: 1 for integer, 2 for real, and 4 for character string.

The next lines specify data values, one value per line. Thus, each control-parameter item must consist of at least five lines. Table 1-2 is a list of the control parameters and provides parameter names, definitions, number of values, data-type flag, and whether the parameter is optional. Control-parameter names are case-sensitive and must be specified as defined in table 1-2. The control-parameter items can be specified in any order in the Control File.

\section{Data File}

A Data File contains measured time-series data used in a PRMS-IV simulation, consisting of three items: a header, inputvariable declaration items, and time-series data items (fig. 2-3). Multiple Data Files can be specified for use in a single simulation. PRMS-IV simulates on a daily time step. Thus, Data Files with time increments other than 24 hours cannot be used.

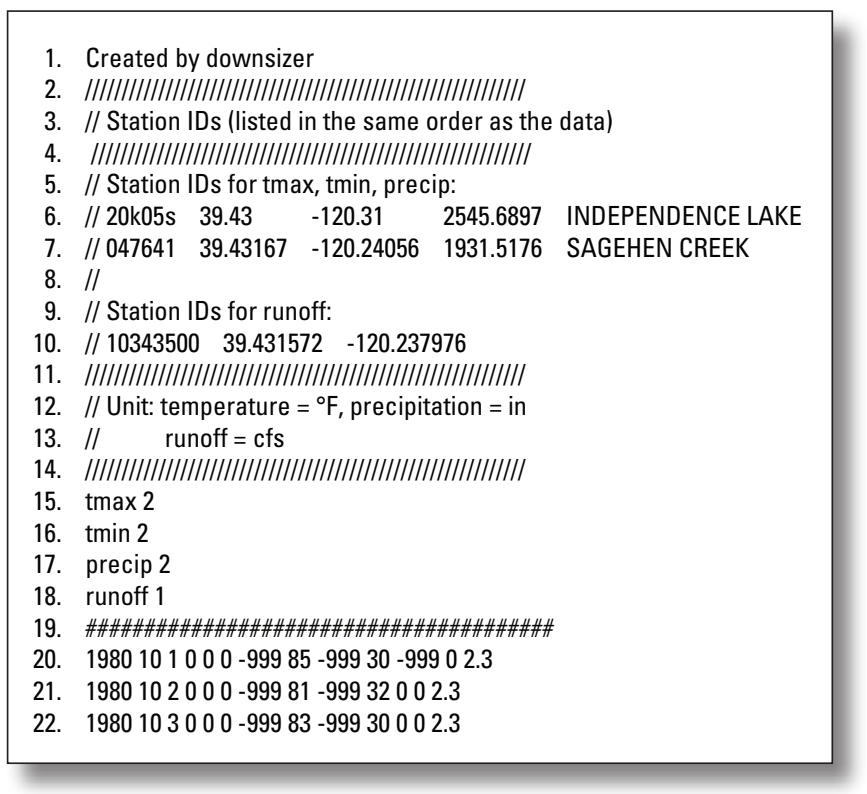

Figure 2-3. Lines from an example Data File. The header and only three lines of data are shown. Note that the line numbers are not part of the Data File but are included here for reference purposes.

The set of Data Files determines the possible range of time of a simulation but not the simulation time period, which is specified by control-parameter items start_time and end_time in the Control File. Both start_time and end_time must be specified as dates and times that occurred between the earliest beginning and latest ending time of the time-series data specified in the Data File(s).

The header item in a Data File is a single line of text, up to 256 characters in length, which can be used by the user to identify the file (fig. 2-3, line 1). Input-variable declaration items are used to specify the type of time-series data included in each Data File. One line is used to identify each time-series data item. Blank lines or comment lines can be included before or after an input-variable declaration item; comment lines begin with two backslashes (//) in columns 1 and 2 to add descriptive information about an input variable (fig 2-3, lines 2-302). Each input-variable declaration item specifies two values: (1) a character string that is the name of the input variable, and (2) an integer value that is the number of values (or columns) specified in each time-series data item for the input variable (fig. 2-3, lines 303-306). The number of values must equal the size of the dimension associated with the input variable as defined by the dimensions specified in the Parameter File. For example, the two input-variable declaration items tmax and tmin indicate that daily maximum and minimum air-temperature data (fig. 2-3, lines 303-304) will be specified for 79 stations in each time-series data item (and dimension ntemp is set to 79 in the dimensions section of the Parameter File). In this example, each time-series data item must contain 79 columns of tmax values followed by 79 columns of tmin values. If the number of values and the associated dimension specified in the Parameter File are different, an error message is printed and model execution stops. 
A delimiter that consists of a single line specifying at least four pound signs (\#\#\#\#; fig. 2-3, line 307) beginning in column 1 indicates the end of the input-variable declaration items and that the next and following lines each specify a timeseries data item for consecutive daily time steps. Each time-series data item consists of columns of values separated by at least one blank space, with the number of columns equal to six plus the sum of the number of values for each input variable (fig. 2-3, lines 308-310). The first six columns specify the time step of each time-series data item as integer values in the order: year, month, day, hour, minute, and second. A time-series data item must be specified for each day. Values for hour, minute, and second must be specified as zero (that is, columns 4 through 6 must be $\left.\begin{array}{lll}0 & 0\end{array}\right)$. The remaining columns for each time-series data item specify the data values.

Table 1-4 is a list of valid time-series input variables and provides definitions, units, valid range, and the dimension name associated with each variable. The input-variable names are case-sensitive and must be specified as defined in table 1-4. Missing values can be identified by specifying negative numbers out of the valid range for the input variable.

\section{Parameter File}

The Parameter File specifies dimensions and parameters required for a PRMS-IV simulation. The Parameter File consists of three sections: header, dimensions, and parameters. Figure 2-4 shows a portion of an example Parameter File that includes the header section, a dimensions section with two dimension-declaration items, and parameters section with two parameterdeclaration items. The parameter-declaration items required in the Parameter File depend on the modules that have been selected in the Control File.

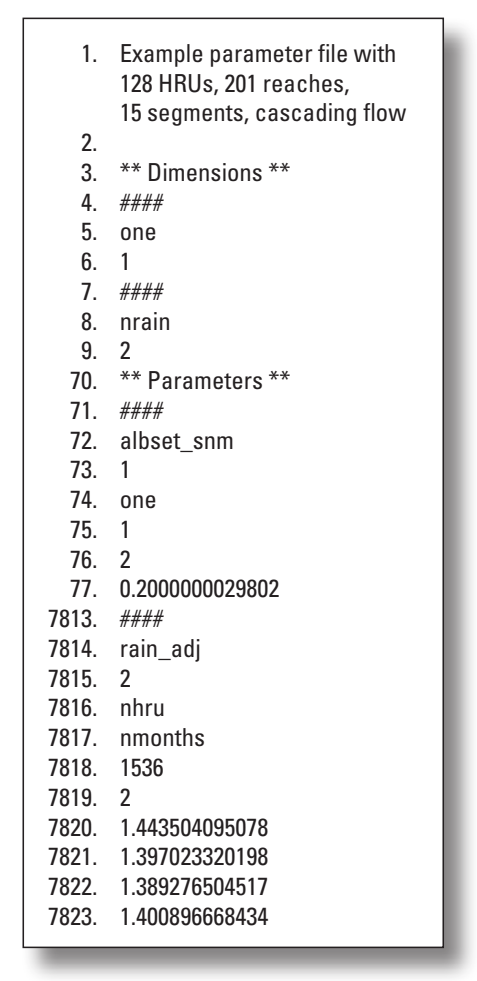

Figure 2-4. Selected lines of an example Parameter File. The header and parts of the dimensions and parameters sections are shown. Note that the line numbers are not part of the Parameter File but are included here for reference purposes.

The first two lines in the header describe the Parameter File (fig. 2-4, lines 1 and 2). These lines can contain up to 256 characters. The dimensions section is used to define the size of dimensions that are used to allocate memory for parameters and variables required by the PRMS-IV modules. The dimensions section begins with the dimensions identifier (fig. 2-4, line 3). The identifier is followed by a series of 3-line dimension-declarations items. The first line is used as a delimiter for each of the dimension declarations, specified as a string of four pound signs (\#\#\#\#) that begins in column 1 (fig. 2-4, line 4). The second line is the name of the dimension, specified as a character string without spaces, using lowercase letters (fig. 2-4, line 5). The third line is the dimension size, specified as an integer value (fig. 2-4, line 6). Table 1-1 lists the names, definitions, and default values of the 36 dimensions that can be specified in the dimensions section. This example requires 13 of the 36 possible dimensions (to populate lines 4-42). Dimension-declarations items may be specified in any order in the dimensions section of the Parameter File. 
The dimensions section is followed by the parameters section of the Parameter File (fig. 2-4, line 43). This section contains the parameter-declaration items, each one starting with a line with four pound signs (\#\#\#\#), which are used as a delimiter (fig. 2-4, line 44). The second line of the parameter-declaration item specifies the name of the parameter (fig. 2-4, line 45) (see table 1-3 for a list of valid parameter names). The third line specifies the number of dimensions (fig. 2-4, line 46). The next lines specify the dimension name(s) (fig. 2-4, line 47), one value per line, starting in column one (see table 1-1 for a list of valid dimension names). The dimension name must be specified as one if the parameter is a single value scalar. Most PRMS-IV parameters are singledimensional arrays, including scalars. A few parameters consist of two-dimensional arrays; that is, an array of values that consists of rows and columns. An example parameter that consists of a two-dimensional array of values is rain_adj (fig. 2-4, line 13650). This parameter is defined over the dimensions nhru by nmonths; that is, the parameter has nhru rows and nmonths columns.

The next line (fig. 2-4, line 13654) is an integer that specifies the total number of values that are input for the parameter. For scalars or one-dimensional arrays, this value is the size of the associated dimension, as declared in the dimensions section of the file. The total number of values specified for each two-dimensional parameter is equal to the product of its two dimension sizes. For the rain_adj parameter mentioned above the value is specified as the product of the sizes of nhru and nmonths.

The next line (fig. 2-4, line 13655) indicates the type of the parameter values; options are:

1 for integer

2 for real (single-precision, floating decimal point)

3 for double (double-precision, floating decimal point)

4 for character string

Note, no double-precision real (option 3) parameters are used in PRMS-IV.

The remaining line(s) (fig. 2-4, line 13656) in the parameter-value section contain the parameter value(s). Two-dimensional array values are read column by column. For example, for the rain_adj parameter mentioned above, a value for each hydrologic response unit (HRU) (nhru values) for January are specified first, followed by nhru values for February, and so forth, until a total of the product of nhru and nmonths values are specified (fig. 2-4, line 7818).

Parameter-declaration items can be listed in any order. All PRMS-IV parameters and the modules in which they are used are listed in table 1-3. If multiple parameter-declaration items are specified for the same parameter, the values specified last in the Parameter File will be used. Any parameter not specified in the Parameter File that is required by a PRMS-IV simulation is assigned a default value. Any parameter specified in the Parameter File that is not required by a PRMS-IV simulation is ignored. Warning messages are printed in both cases.

\section{Output Files}

This section describes the primary output files produced by a PRMS-IV simulation: the Water-Budget File, the Map Results File, Statistic Variables File, and Animation File. Any of the variables shown in Appendix 1 (tables 1-4 and 1-5) can be output to the Statistic Variables and Animation Files.

\section{Water-Budget File}

The Water-Budget File (fig. 2-5) provides model-domain summary table(s). The pathname of the Water-Budget File is specified by control parameter model_output_file in the Control File. Three types of summary tables are available, depending on the value specified for parameter print_type in the Parameter File. The first (print_type $=0$ ) is a listing of the measured streamflow at a station and simulated streamflow produced for the whole model domain. The second (print_type $=1$ ) is a table of the area-weighted averages of net precipitation, evapotranspiration, storage, and the simulated and measured streamflows. The

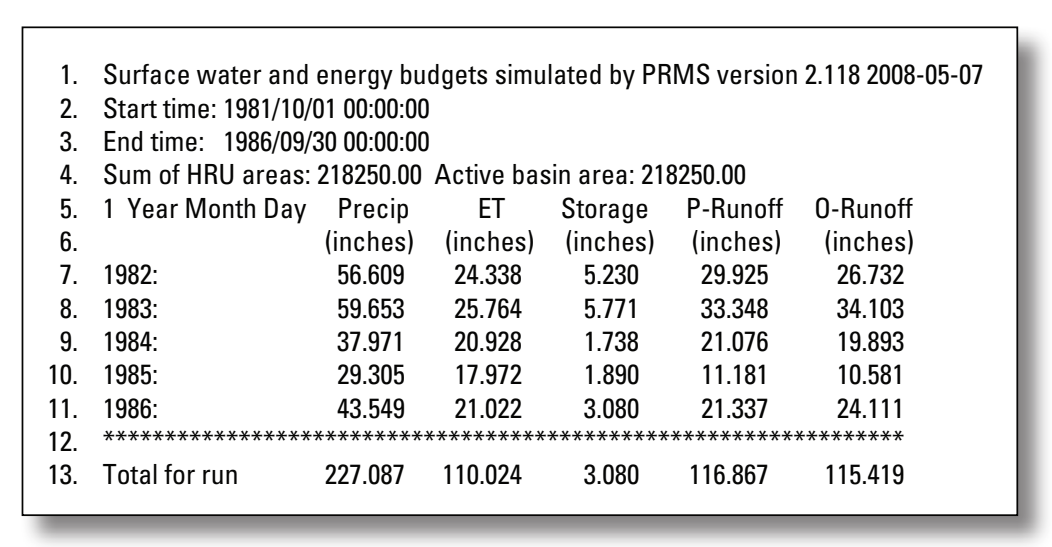
third (print_type $=2$ ) is a detailed summary of states and fluxes. The frequency of output is specified by parameter print_freq in the Parameter File_-daily (print_freq $=8$ ), monthly (print_freq $=4$ ), yearly (print_freq=2), total (print_freq=1) simulation time, or any additive combination.

Figure 2-5. Selected lines of an example Water-Budget File. The header and table sections are shown. Note that the line numbers are not part of the Water-Budget File, but are included here for reference purposes. 


\section{Statistic Variables File}

The Statistic Variables File (fig. 2-6) is a text file that provides model results as a time series of selected output variables that can be used with visualization and statistics programs. This file is commonly referred to as the "statvar" file. The file is generated when the control parameter statsON_OFF is set to 1 in the Control File. The name of the file is set by control parameter stat_var_file. The first line of the file is the number of variable values that are written in the file; this value is specified by using control parameter nstatVars. The next group of lines (nstatVars in number) lists the names and array indices of each output variable; the output variables that are listed are specified by using control parameter statVar_names. The array index for variables that are scalar, meaning a single value, is set to 1 . The remaining lines provide the model-calculated values. These data lines have the following order: model time-step number, year, month, and day of month, hour, minute, second, and each variable value in the order specified by the list of variable names. Each value is separated by a space.

\begin{tabular}{|c|c|c|}
\hline \multicolumn{3}{|c|}{$\begin{array}{l}2 \\
\text { basin_cfs } 1 \\
\text { runoff } 1\end{array}$} \\
\hline & 198710 & 10003.1203032 .100000 \\
\hline & 198710 & 20003.1089142 .100000 \\
\hline & 198710 & 30003.0975672 .100000 \\
\hline & 198710 & 40003.0862602 .100000 \\
\hline & 198710 & 50003.0749962 .100000 \\
\hline & 198710 & 60003.0637722 .100000 \\
\hline & 198710 & 70003.0525892 .100000 \\
\hline & 198710 & 80003.0414472 .100000 \\
\hline & 198710 & 90003.0303462 .200000 \\
\hline & 1987101 & 00003.0192852 .200000 \\
\hline & 1987101 & 10003.0082652 .200000 \\
\hline & 1987101 & 20003.2118402 .800000 \\
\hline & 1987101 & 30003.0528222 .400000 \\
\hline & 1987101 & 40003.0211132 .300000 \\
\hline & & \\
\hline
\end{tabular}

Figure 2-6. Selected output from a Statistic Variables (statvar) File that lists simulated (basin_cfs) and measured (runoff) streamflow. The header and data sections are shown.

\section{Animation File}

The Animation File (fig. 2-7) is a text file that provides model results as a time series of spatial arrays for selected output variables that can be used with visualization and statistics programs. The file is generated when control parameter aniOutON_OFF is set to 1 in the Control File. The name of the file is set by control parameter ani_output_file. The first group of lines in the file, starting with pound characters (\#), describes the format of the file (that is, provides metadata that define the file

$\#$

\# Begin DBF

\# timestamp,\#FIELD ISODATETIME,19,0

\# nhru,\#FIELD_DECIMAL, 10,2

\# pkwater_equiv,\#FIELD_DECIMAL,10,2

\# soil_moist,\#FIELD_DECIMAL,10,2

\# hru_actet,\#FIELD_DECIMAL,10,2

\# End DBF

\#

timestamp nhru pkwater_equiv $19 \mathrm{~d} 10 \mathrm{n} 10 \mathrm{n}$ 10n 10n

1987-10-01:00:00:00 10.000e+000

1987-10-01:00:00:00 $\quad 20.000 \mathrm{e}+000$

1987-10-01:00:00:00 $30.000 \mathrm{e}+000$

1987-10-01:00:00:00 $\quad 40.000 \mathrm{e}+000$

1987-10-01:00:00:00 $\quad 50.000 \mathrm{e}+000$

1987-10-01:00:00:00 $\quad 60.000 \mathrm{e}+000$

1987-10-01:00:00:00 $\quad 70.000 \mathrm{e}+000$

1987-10-01:00:00:00 $\quad 80.000 \mathrm{e}+000$

1987-10-01:00:00:00 $\quad 90.000 \mathrm{e}+000$

1987-10-01:00:00:00 $100.000 \mathrm{e}+000$

1987-10-01:00:00:00 $\quad 110.000 \mathrm{e}+000$

1987-10-01:00:00:00 12 $0.000 \mathrm{e}+000$

1987-10-01:00:00:00 $130.000 \mathrm{e}+000$

1987-10-01:00:00:00 $140.000 \mathrm{e}+000$

1987-10-01:00:00:00 $150.000 \mathrm{e}+000$ format and contents); these lines can be used by external programs to reformat the file. The first line beyond the metadata is a tab-separated list of names of the output variables whose values are provided in a column in each data line. These output variables are specified by using control parameter aniOutVar_names. The next line is a tab-separated list of the field width and data type, defined as a single text string, of each output variable in the same sequence as the list of variable names. The remaining lines provide the model-calculated values, containing the date and corresponding index number within the spatial feature dimension and variable values in the order specified by the list of variable names for each simulation time step. A date value (or timestamp) is output as a 19-character string in the following format: YEAR-MO-DY : HR: MN : SE. The index number is an integer value. Data values are numbers written in a 10 -character exponential format.

Figure 2-7. Selected output from an example of an Animation File that lists snowpack-water equivalent, soil moisture, and actual evapotranspiration,for each hydrologic response unit. The header and data sections are shown. 


\section{Map Results File}

The Map Results Module generates up to three Map Results Files for each specified variable when control parameter mapOutON_OFF is specified with the value 1. The list of variables is specified by using control parameter mapOutVar_ names. Only variables that have the number of HRU values can be included in Map Results Files. The number of Map Results Files for each variable is determined from the value of parameter mapvars_freq. This parameter is similar to control parameter print_freq, as described in section "Water Budget File" in this appendix. For mapvars_freq = 1, 2, 3, or 6 one Map Results File for each variable is generated, with file names "variable_name.monthly," "variable_name.yearly," "variable_name.total," and "variable_name.weekly," respectively. For example, when mapvars_freq $=4$, the monthly and yearly files are generated; likewise, when mapvars_freq $=5$, the monthly, yearly, and total files are generated.

All Map Results Files, regardless of time step, have the same output format. An output item is written for each time step. First, a line that specifies the ending date and the basin area-weighted mean value for the time step is written. Next, the results for the HRU spatial units as mapped to the target spatial units is written over multiple lines, each line containing ncol number of values. The number of lines of values equals the dimension ngwcell divided by ncol. If ngwcell is not an even multiple of ncol, the last will have fewer than ncol number of values. An example Map Results File for a yearly summary is shown in figure 2-8. Finally, a line with 22 “\#” characters and a blank line are written as a delimiter and signify the end of the output item.

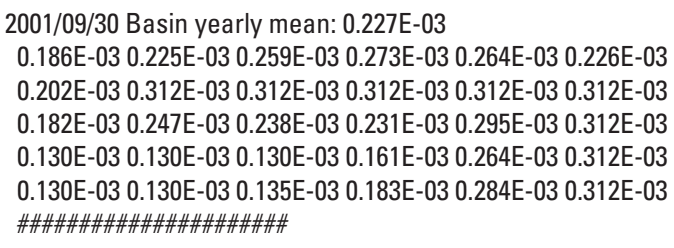

Figure 2-8. Selected output from an example of a Map Results File that lists yearly output of recharge values for a 6-by 5-grid.

The first line of a Map Results File that summarizes the entire simulation period specifies the time period and basin areaweighted mean value for the time period. This file contains only one output item and does not need an output item delimiter. An example Map Results File for a total summary is shown in figure 2-9.

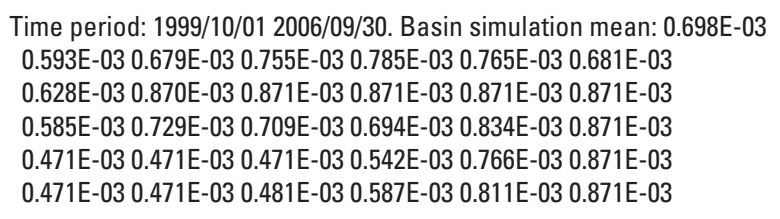

Figure 2-9. Selected output from an example of a Map Results File that lists total simulation period output of recharge values for a 6-by-5 grid.

\section{Climate by HRU Files}

The CBH files are used as input by module climate_hru (described in section "climate_hru" in Appendix 1). To activate this option, set the control parameter model_mode to the value WRITE_CLIMATE. When this option is selected, PRMS-IV writes the values computed for each HRU by the selected modules for the temperature, precipitation, solar radiation, and potential evapotranspiration distribution processes (see table 2 for complete list of modules available for each process) to individual CBH Files. The modules used for simulation of these processes are specified by the control parameters temp_module, precip_ module, et_module, solrad_module, and transp_module, respectively (see table 1-2 in Appendix 1 for descriptions of these control parameters). CBH Files are not written for any process that is simulated with the climate_hru module. All CBH Files are written to the user's current directory. After the CBH Files have been generated, it is necessary to set control parameter model_mode back to PRMS for regular simulations.

The file name for each CBH File is determined by combining the climate variable name with the suffix "_day". The temperature process will produce two CBH Files, one each for maximum and minimum daily temperature, tmax_day and tmin_day, respectively. A single CBH File will be written for each of the other climate distribution processes, precip_day, potet_day, swrad_day, and transp_day, respectively.

The $\mathrm{CBH}$ files have the same format as the Data Files (fig. 2-3). Each CBH file includes distributed values for one variable, with the number of values equal to the number of HRUs. The WRITE_CLIMATE flag for control parameter model_mode writes the values for each time step as a single line. The format allows use of a CBH file as input to spreadsheet software that accepts text files with space delimited values (fig. 2-10). 
Generated by write_climate_hru module

precip 829

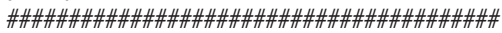

19961010000.00000 .00000 .00000 .00000 .00000 .0000

$\begin{array}{lllllllll}199610 & 2000 & 0.0145 & 0.0144 & 0.0120 & 0.0118 & 0.0135 & 0.0127\end{array}$

$\begin{array}{llllllllll}1996103000 & 0.0048 & 0.0048 & 0.00450 .0048 & 0.0047 & 0.0041\end{array}$

19961040000.00000 .00000 .00000 .00000 .00000 .0000

19961050000.00000 .00000 .00000 .00000 .00000 .0000

19961060000.00000 .00000 .00000 .00000 .00000 .0000

19961070000.00000 .00000 .00000 .00000 .00000 .0000

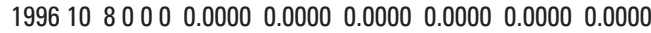

$\begin{array}{lllllll}1996109000 & 0.0827 & 0.0823 & 0.0837 & 0.0815 & 0.0813 & 0.0869\end{array}$

$\begin{array}{lllllllll}1996 & 10 & 10000 & 0.0868 & 0.0879 & 0.0975 & 0.1000 & 0.0925 & 0.0929\end{array}$

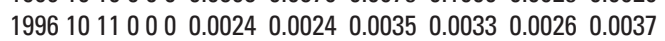

199610120000.00000 .00000 .00000 .00000 .00000 .0000

$\begin{array}{llllllllllllll}199610 & 13000 & 0.0139 & 0.0137 & 0.0114 & 0.0111 & 0.0128 & 0.0122\end{array}$
Figure 2-10. Selected output from an example of a Climate by hydrologic response unit (HRU) (CBH). File containing precipitation data (precip) for six HRUs.

\section{Running the PRMS-IV Executable}

PRMS-IV runs from the command line in either a text based window or by double clicking on the appropriate icon in a Windows browser.

\section{Command Line Execution}

The simplest way to run PRMS-IV is from a directory that contains the PRMS-IV executable and a Control File named "prms.control" with the command:

prms

Alternatively, specify the name of a Control File as the first command line argument:

prms control file name

Use the "-set" flag on the command line to override any control parameter set in the Control File. For example, to change the start time of the simulation:

prms control_file_name -set start_time 1994,10,1,0,0,0

To change the name of the Parameter File:

prms control file name -set param file./input/example.params

Use the "-por" flag to simulate the full time period specified in the Data File:

prms -por

Use the "-print” flag to generate the Parameter Name File, Variable Name File, Module Name File and the Default Parameter File:

prms -print

The files generated with the "-print" flag are described below.

\section{Parameter Name File}

The Parameter Name File describes the dimensions and parameters used by the active modules that are selected in the Control File. This file is written into the directory with the Control File and uses the name of the Control File with ".par_name" appended. The Parameter Name File consists of three sections: header, dimensions, and parameters. Figure 2-11 shows a portion of an example Parameter Name File. Shown are the header section, one dimension item, and one parameter item. This file is used by the Object User Interface (Markstrom and Koczot, 2008), Luca (Hay and Umemoto, 2007), and other tools that run and calibrate PRMS-IV. This file also provides useful debugging information. 


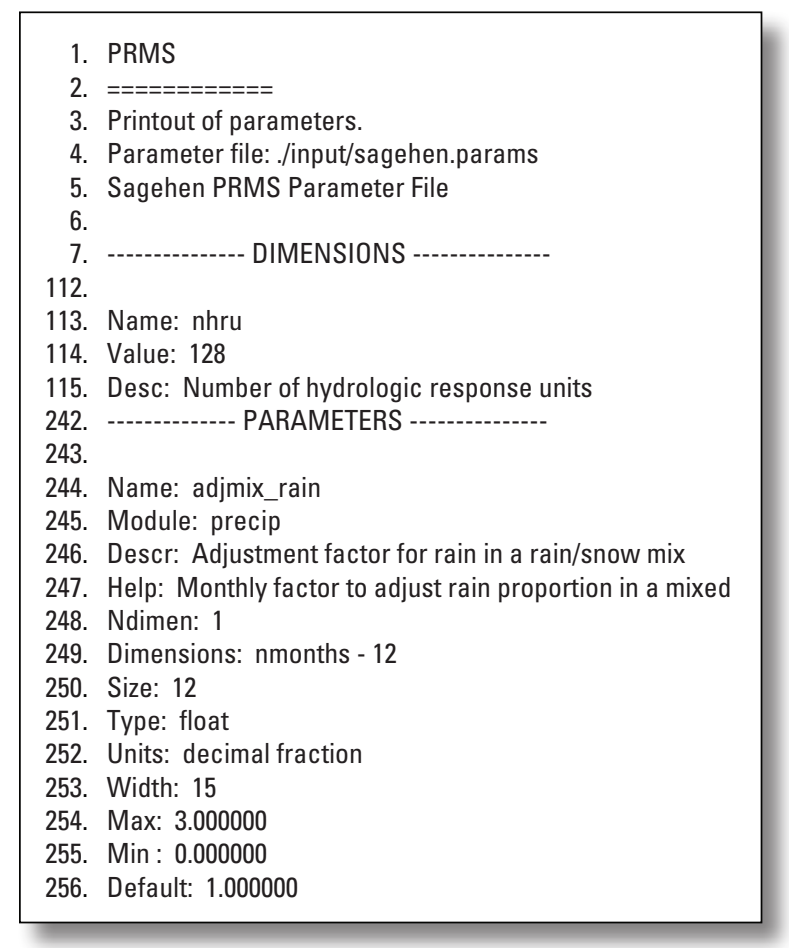

Figure 2-11. Selected lines of an example Parameter Name File. The header, dimensions, and parameters sections are shown. Note that the line numbers are not part of the Parameter Name File but are included here for reference purposes.

The header of the Parameter Name File specifies the name of the Parameter File used for the simulation (fig. 2-11, line 3). The dimensions section reports the size of all dimensions. The dimensions section begins with the dimensions identifier (fig. 2-11, line 7). This identifier is followed by a series of four-line dimension items. The first line is blank and is used as a delimiter for each of the dimension items (fig. 2-11, line 112). The second line is the name of the dimension (fig. 2-11, line 113). The third line is the dimension size (fig. 2-11, line 114). The fourth line is the description of the dimension (fig. 2-11, line 115). This 4-line pattern is repeated for each dimension.

The parameters section begins with the parameters identifier (fig. 2-11, line 242). The identifier is followed by a series of 14-line parameter items. The first line is blank and is used as a delimiter for each of the parameter items (fig. 2-11, line 243). The second line is the name of the parameter (fig. 2-11, line 244). The third line is the module in which the parameter was declared (fig. 2-11, line 245). The fourth line is the description of the parameter (fig. 2-11, line 246). The fifth line is the help text for the parameter (fig. 2-11, line 247). The sixth line is the number of dimensions for the parameter (fig. 2-11, line 248). The seventh line is a list of dimensions used by the parameter (fig. 2-11, line 249). The eighth line is the array element size of the parameter (fig. 2-11, line 250). The ninth line is the data type of the parameter (fig. 2-11, line 251). The tenth line is the unit of the parameter (fig. 2-11, line 252). The eleventh line is the column width used to display the values of the parameter in a table (fig. 2-11, line 253). The twelfth line is the maximum valid value of the parameter (fig. 2-11, line 254). The thirteenth line is the minimum valid value of the parameter (fig. 2-11, line 255). The fourteenth line is the default value of the parameter (fig. 2-11, line 256). This pattern is repeated for each parameter.

\section{Variable Name File}

The Variable Name File describes the variables used by the active modules that are selected in the Control File. This file is always written into the directory with the Control File and uses the name of the Control File with ".var_name" appended. The Variable Name File consists of two sections: header and variables. Figure 2-12 shows a portion of an example Variable Name File. Shown are the header section and one variable item. The information contained in this file is used by the Object User Interface (Markstrom and Koczot, 2008), Luca (Hay and Umemoto, 2007), and other tools that run and calibrate PRMS-IV. This file also provides useful debugging information. 


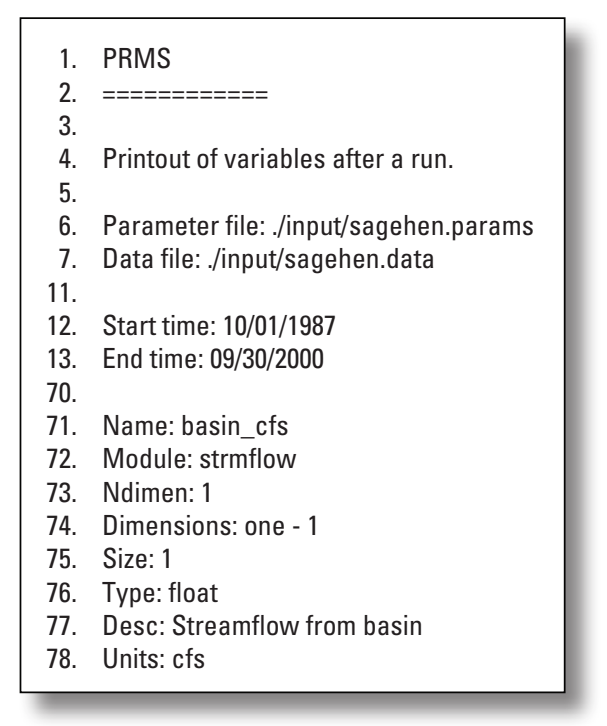

Figure 2-12. Selected lines of an example Variable Name File. The header and variables sections are shown. Note that the line numbers are not part of the Variable Name File but are included here for reference purposes.

The header of the Variable Name File specifies the name of the Parameter File (fig. 2-12, line 6) and the Data File (fig. 2-12, line 7) used for the simulation. Start and end times are shown on lines 12 and 13, respectively. The variables section begins after the header section is finished (fig. 2-12, line 16, not shown). Each variable item is a series of 9-lines. The first line is blank and is used as a delimiter for each variable item (fig. 2-12, line 70). The second line is the name of the variable (fig. 2-12, line 71). The third line is the module in which the variable was declared (fig. 2-12, line 72). The fourth line is the number of dimensions for the variable (fig. 2-12, line 73). The fifth line is a list of dimensions used by the variable (fig. 2-12, line 74). The sixth line is the array element size of the variable (fig. 2-12, line 75). The seventh line is the data type of the variable (fig. 2-12, line 76). The eighth line is the description of the variable (fig. 2-12, line 77). The ninth line is the units of the variable (fig. 2-12, line 78). This pattern repeats for each variable.

\section{Module Name File}

The Module Name File lists the active modules. This file is written into the directory with the Control File and uses the name of the Control File with ".mod_name" appended. The Module Name File consists of two sections: header and modules. Figure 2-13 shows a portion of an example Module Name File. Shown are the header section and three module items. The information contained in this file is used by the Object User Interface (Markstrom and Koczot, 2008), Luca (Hay and Umemoto, 2007), and other tools used to aid in running and calibrating of PRMS-IV. This file also provides useful debugging information.

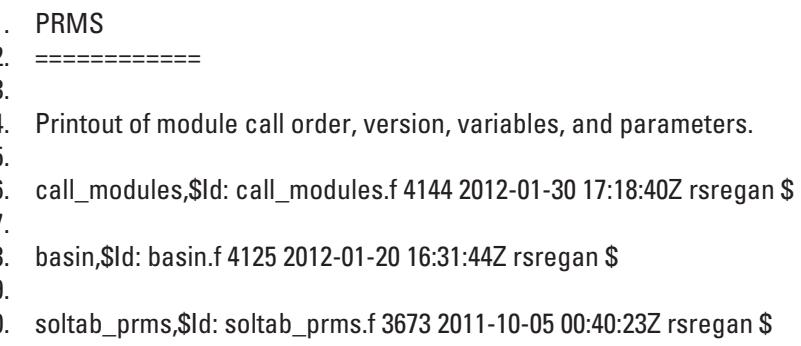

Figure 2-13. Selected lines of an example Module Name File. The header and modules sections are shown. Note that the line numbers are not part of the Module Name File but are included here for reference purposes. 
The header of the Module Name File is fixed (fig. 2-13, lines 1-4). The modules section begins after the header section is finished (fig. 2-13, line 6). Each module item is a single line. The module item line (fig. 2-13, line 6) contains the name of the module and the file version identifier string.

\section{Default Parameter File}

The Default Parameter File is a PRMS-IV format Parameter File as described in section "Parameter File" in this appendix. This file is written into the directory with the Control File and uses the name of the Control File with ".param" appended. Figure 2-4 shows a portion of an example Parameter File. The Default Parameter File contains all dimensions and parameters required as input for the active modules. If the Parameter File name(s) specified in the Control File does not exist, the Default Parameter File will be created with default values; otherwise, the Default Parameter File is created by: (1) removal of any unused parameters; (2) addition of any required parameters, which are assigned default values; (3) retaining all currently specified dimensions and parameters; and (4) combining multiple parameter files, if specified.

\section{Script Execution}

In many situations, it is convenient to write Windows batch files or Linux shell scripts to run PRMS-IV. For example, specifying long command-line arguments is tedious and prone to error. The example included with the PRMS-IV distribution (Appendix 3) includes many examples of Windows batch files. These files are identified by their ".bat" extension. In addition, users may want to run PRMS-IV many times while using different Data or Parameter Files. Figure 2-14 shows an example Linux Korn shell script with nested loops. In this example, the model is used to make 7 runs (each one year in length for water years 1970 to 1976) for three separate watersheds (East, Yampa, and Sagehen), which results in a total of 21 runs.

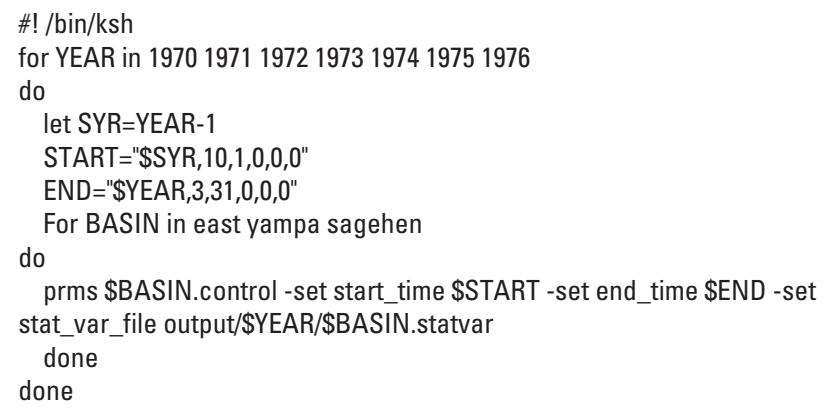

Figure 2-14. Example of a Linux Korn shell script that runs the Precipitation-Runoff Modeling System (prms) executable 21 times with nested loops.

\section{Supporting Software for PRMS-IV}

A number of software tools can be used to develop PRMS-IV applications. A graphical user interface for PRMS-IV (fig. 1-15) is described by Markstrom and Koczot (2008). This is an alternative to executing PRMS-IV with the command line. Also, parameter values in the Control and Parameter Files can be modified within the interface rather than making changes with a line editor. Luca is the sensitivity and optimization tool for PRMS-IV (fig. 2-16) and is described by Hay and Umemoto, 2007. The Downsizer is the climate and streamflow time-series Data File creation tool for PRMS-IV (fig. 2-17) and is described by Ward-Garrison and others, 2009. In addition to downloading online data, the Downsizer also writes daily precipitation, air temperature, and streamflow data into Data File format. 
Modular Modeling System

File Edit Run Help

\begin{tabular}{|l|}
\hline \multicolumn{1}{|c|}{ Model Information } \\
\hline Name: \\
.J../bin/prms2008 \\
Description: \\
PRMS-2008 \\
\\
\end{tabular}

\section{Name:}

Icontrolisagehen.control

Description:

PRI E mus Run Control - Single Run
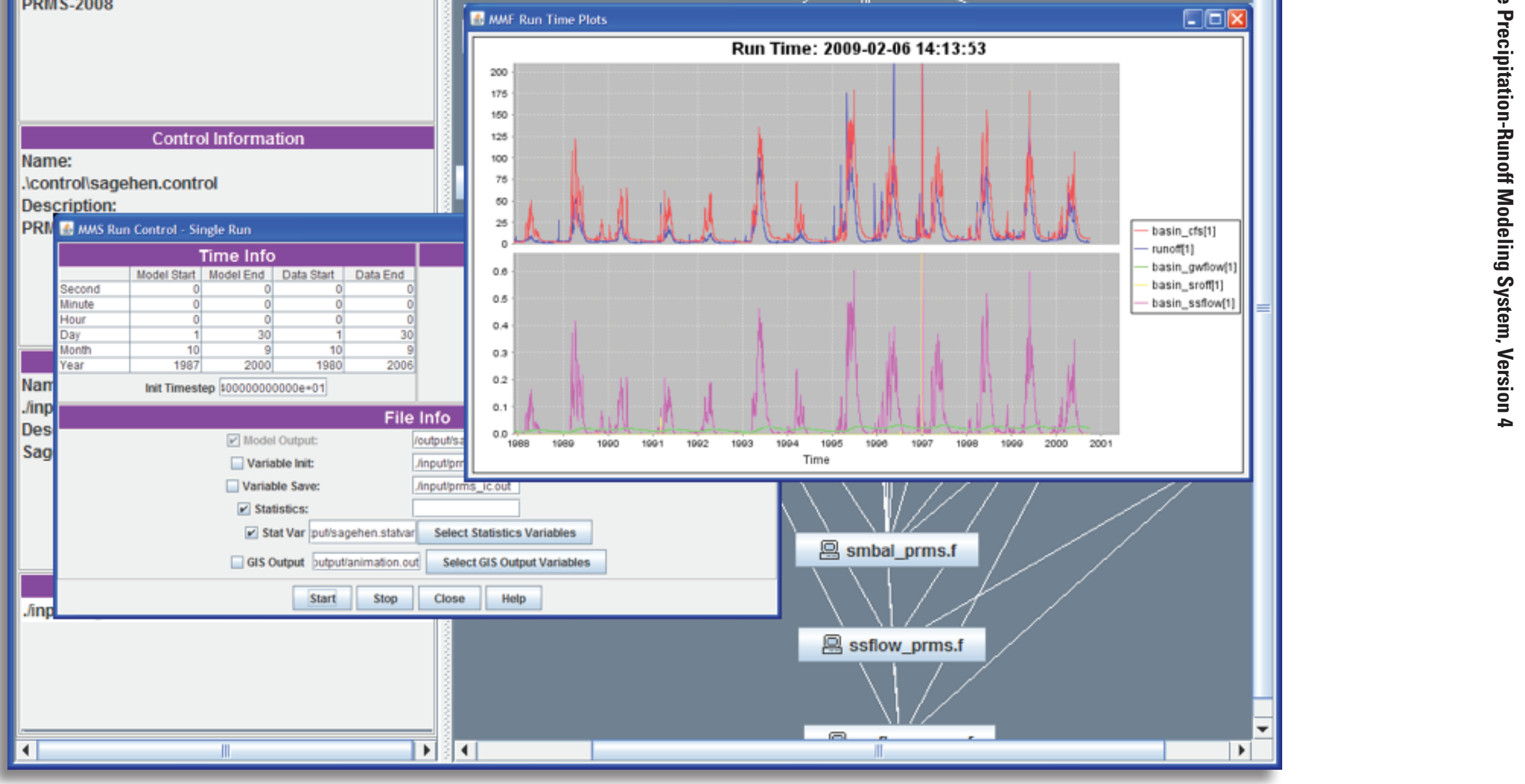

Figure 2-15. Screen image showing Precipitation-Runoff System running inside of the Object User Interface (from Markstrom and Koczot, 2008). 


\section{Steps}

1. Start Session

2. Rounds \& Steps

3. Directory \& Input Files

4. Calbration Period

5. Parameter Selection

6. Calbration Strategy

7. SCE Control Parameters

8. Multi-Objective Function Setup

9. Indvidual Objective Function Setup

10. Simulated \& Observed Variables

11. Output Files

12. Save Session

13. Calibration Run

\section{Calibration Run (13 of 13)}

Calibration Current State

$$
\begin{aligned}
\text { Round } 0 \\
\text { Step } 0
\end{aligned}
$$

Model Excecution 0

0

Objective Function Value

Best Values \& Status for each Step of each Round

\begin{tabular}{|c|} 
Stuca Result \\
Step 1 \\
Step 2 \\
Step 3 \\
Step 4 \\
Round 2 \\
Step 1 \\
Step 2 \\
Step 3 \\
Step 4 \\
Round 3
\end{tabular}

1... Round 3

- Step 1
Ready to nun.

Objective Function Valje

Output Parameter File Flint_round1_step1.par

dday_intcp tmax_index

\begin{tabular}{l|l}
9.83435 & 53.994286 \\
\hline-39.35717 & 53.114365
\end{tabular}

\begin{tabular}{l|l}
-39.35717 & 53.114365
\end{tabular}

$9.604676 \quad 81.606972$

\begin{tabular}{|l|l}
\hline 9.647164 & 76.228584
\end{tabular}

$-1.657423 \quad 68.294479$

\begin{tabular}{l|l}
\hline 6.578891 & 84.567688
\end{tabular}

\begin{tabular}{|l|l|}
\hline 0.578091 & 84.567688 \\
\hline 2.518553 & 65.776917 \\
\hline
\end{tabular}

\section{Calibration Trace File: will not be generated}

Summary File:

Figure 2-16. Screen image showing Precipitation-Runoff Modeling System running inside of Luca (from Hay and Umemoto, 2007). 


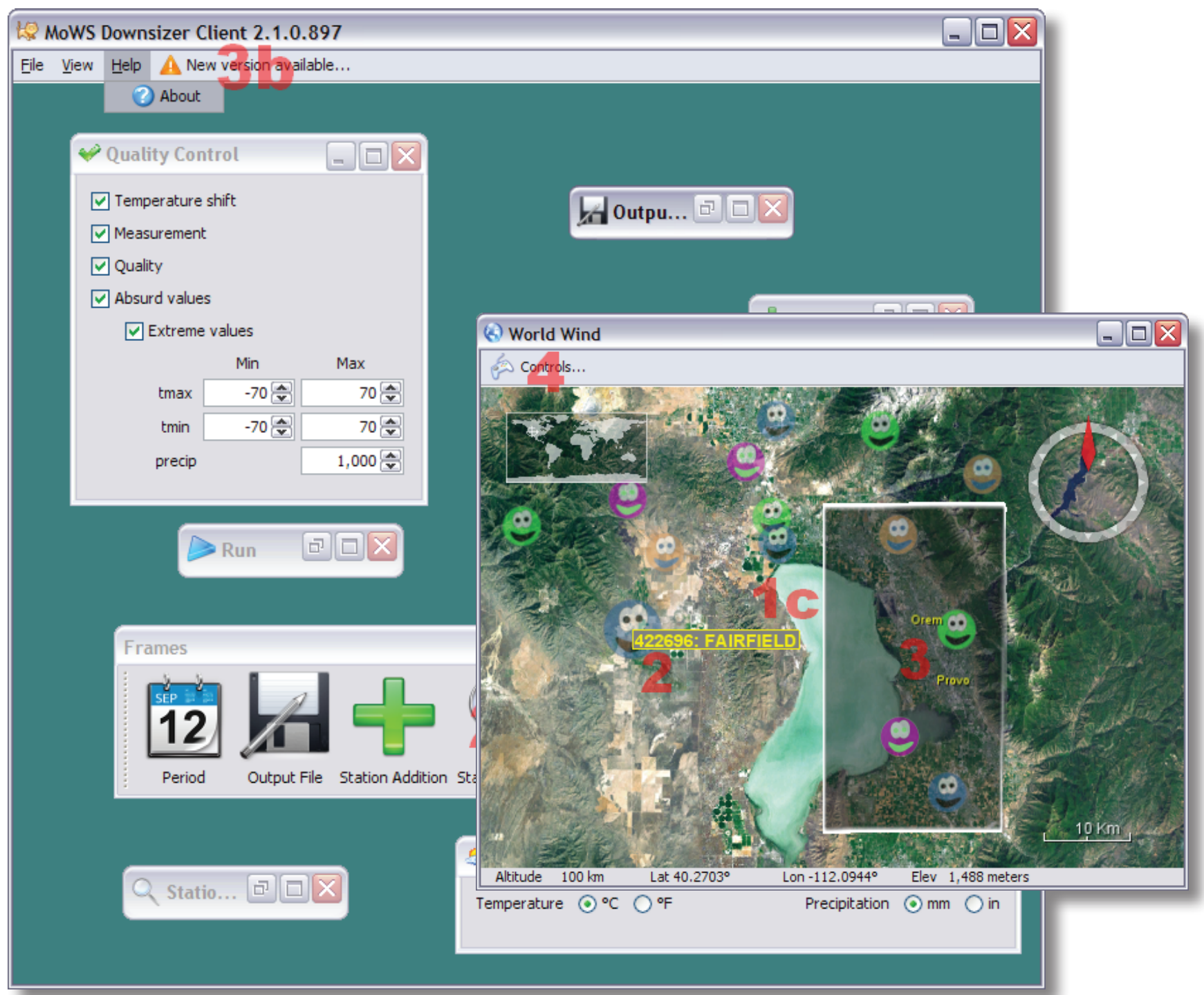

Figure 2-17. Screen image showing the Downsizer (from Ward-Garrison and others, 2009). 


\section{References Cited}

Hay, L.E., and Umemoto, Makiko, 2007, Multiple-objective stepwise calibration using Luca: U.S. Geological Survey Open-File Report 2006-1323, 25 p., at http://pubs.usgs.gov/ of $/ 2006 / 1323 /$.

Leavesley, G.H., Restrepo, P.J., Markstrom, S.L., Dixon, M., and Stannard, L.G., 1996, The Modular Modeling System (MMS) - User's manual: U.S. Geological Survey Open-File Report 96-151, 142 p.

Markstrom, S.L., and Koczot, K.M., 2008, User's manual for the Object User Interface (OUI) - An environmental resource modeling framework: U.S. Geological Survey Open-File Report 2008-1120, 39 p., at http://pubs.usgs.gov/ of $/ 2008 / 1120 /$.

Viger, R.J., and Leavesley, G.H., 2007, The GIS Weasel user's manual: U.S. Geological Survey Techniques and Methods, book 6, chap. B4, $201 \mathrm{p}$.

Ward-Garrison, C.D., Markstrom, S.L., and Hay, L.E., 2009, Downsizer-A Graphical user interface based application for browsing, acquiring, and formatting time series data for hydrologic modeling: U.S. Geological Survey OpenFile Report 2009-1166, 27 p., at http://pubs.usgs.gov/ of $/ 2009 / 1166 /$. 



\section{Appendix 3. PRMS-IV Merced River Example Application}

\section{Contents}

Appendix 3. PRMS-IV Merced River Example Application...........................................................143

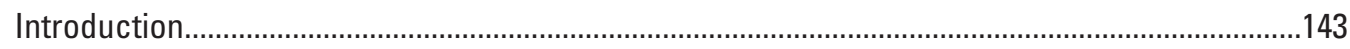

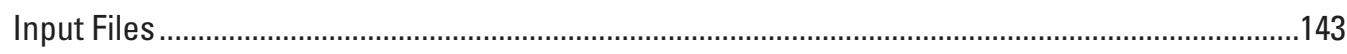

Hydrologic Response Unit Delineation .............................................................................. 147

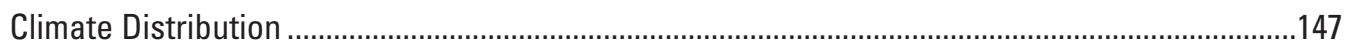

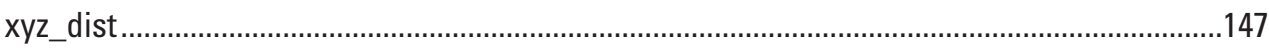

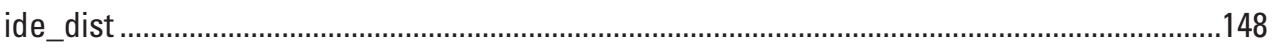

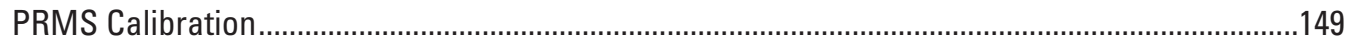

Calibration Step 1-Solar Radiation.............................................................................151

Calibration Step 2 —Potential Evapotranspiration ...........................................................151

Calibration Step 3 -Streamflow Volume .......................................................................151

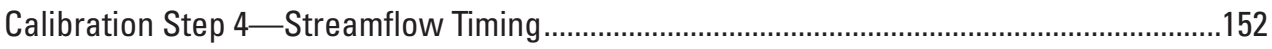

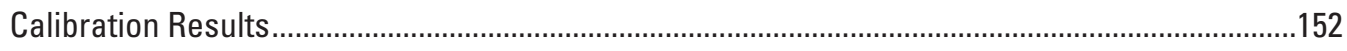

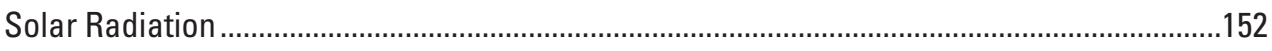

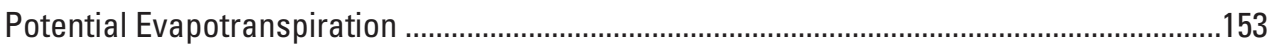

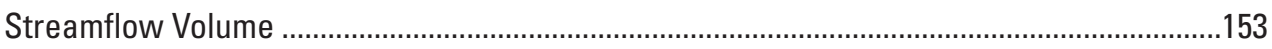

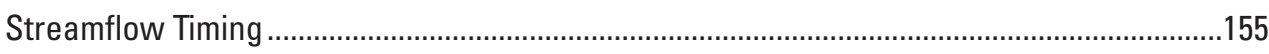

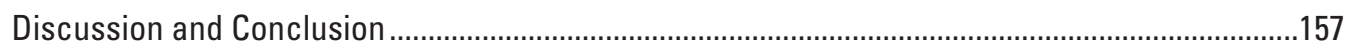

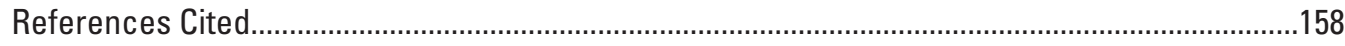

\section{Figures}

3-1. Multi-objective, step-wise calibration procedure for a Precipitation-Runoff Modeling System, version 4 (PRMS-IV) application

3-2. Measured, calibrated, and evaluated watershed mean-monthly solar radiation for the calibration and evaluation periods. (XYZ, xyz_dist module; IDE, ide_dist module)

3-3. Measured, calibrated, and evaluated watershed mean-monthly potential evapotranspiration for the calibration and evaluation periods. (XYZ, xyz_dist module; IDE, ide_dist module)..

3-4. Measured, calibrated, and evaluated mean-annual streamflow for the calibration (red line) and evaluation periods. (XYZ, xyz_dist module; IDE, ide_dist module)

3-5. Measured and simulated mean-monthly streamflow for the calibration and evaluation periods. (XYZ, xyz_dist module; IDE, ide_dist module).

3-6. Measured versus simulated monthly mean streamflow for the calibration and evaluation periods. (XYZ, xyz_dist module; IDE, ide_dist module). 
3-7. Annual Nash Sutcliffe goodness of fit values for daily flows for the calibration and evaluation periods. (XYZ, $x y z$ _dist module; IDE, ide_dist module).

3-8. Measured and simulated daily streamflow for the calibration and evaluation periods. (XYZ, XYz_dist module; IDE, ide_dist module)

\section{Tables}

3-1. Climate station list for the Merced River basin. Stations are maintained as part of either the National Weather Service Cooperative (NWS) network or the the Natural Resources Conservation Service Snow Telemetry (SNOTEL) network ............144

3-2. Number of missing days per water year for temperature and precipitation stations in and around the Merced River Basin

3-3. Modules used in the Precipitation-Runoff Modeling System Merced River application in the order they are called

3-4. Multiple linear regression coefficients for the Merced watershed

3-5. Parameters calibrated in each step of the calibration process for a Precipitation-Runoff Modeling System, version 4 (PRMS-IV) application of the Merced River Basin 


\section{Appendix 3. PRMS-IV Merced River Example Application}

\section{Introduction}

This appendix describes an example Precipitation-Runoff Modeling System, version 4 (PRMS-IV) application for simulation of the watershed above the Merced River at Pohono Bridge near Yosemite National Park (NP), California (Calif.) (U.S. Geological Survey [USGS] streamflow-gaging station 11266500). The Merced River is a mountainous watershed where the runoff is strongly dependent on snowmelt. See Sorenson (1982) for more details about the Merced River setting. The part of the watershed modeled in this example is 517 square kilometers in area and ranges in elevation from 1,200-3,320 meters. This example compares the use of the xyz_dist and ide_dist modules (described in Appendix 1, this report) for precipitation and temperature distribution and utilizes the Luca software (Hay and Umemoto, 2007) for calibration. All files, including documentation, input and output data, source code, Luca, and the executable files necessary to run this example are available from the PRMS web page (http://wwwbrr.cr.usgs.gov/projects/SW_MoWS/PRMS.html, accessed January 2014).

The initial and calibrated Parameter Files provided with the Merced River example application, including data, plots, tables, and other simulation results described in this section, should not be used for assessing water-resource assets in the Merced River watershed. The input and output data sets and simulation results are provided for illustrative purposes only and may not match the current software distribution exactly.

\section{Input Files}

The Data File was assembled for the PRMS-IV Merced River watershed application for the time period October 1, 1989 through September 30, 2008 by using the Downsizer software (Ward-Garrison and others, 2009), a computer application that selects, downloads, verifies, and formats station-based time-series data. The Data File includes daily measured streamflow from the Merced River near Yosemite NP, Calif. (USGS streamflow-gaging station 11266500; http://waterdata.usgs.gov/usa/nwis/ $u v ? 11266500$, accessed October 2014) and daily maximum and minimum temperatures and precipitation data from 26 climate stations, in and around the watershed, compiled from the National Weather Service Cooperative network (http://www.ncdc.noaa. gov/data-access/land-based-station-data/land-based-datasets/cooperative-observer-network-coop, accessed October 2014) and the Natural Resources Conservation Service Snow Telemetry network of observing stations (http://www.wcc.nrcs.usda.gov/snow/, accessed October 2014). Only one of these climate stations (049855) is actually located within the watershed. Table 3-1 lists the climate station identification, type, location, and elevation. Table 3-2 lists the number of missing days occurring in each water year for the climate stations listed in table 3-1. 
Table 3-1. Climate station list for the Merced River basin. Stations are maintained as part of either the National Weather Service Cooperative (NWS) network or the the Natural Resources Conservation Service Snow Telemetry (SNOTEL) network.

[ID, identifier]

\begin{tabular}{|c|c|c|c|c|}
\hline $\begin{array}{l}\text { Station } \\
\text { ID }\end{array}$ & $\begin{array}{l}\text { Station } \\
\text { type }\end{array}$ & $\begin{array}{c}\text { Longitude } \\
\text { (decimal degrees) }\end{array}$ & $\begin{array}{c}\text { Latitiude } \\
\text { (decimal degrees) }\end{array}$ & $\begin{array}{r}\text { Elevation } \\
\text { (meters) }\end{array}$ \\
\hline 049855 & NWS & -119.590 & 37.750 & 1,225 \\
\hline 044881 & NWS & -119.119 & 37.957 & 2,072 \\
\hline 042756 & NWS & -119.231 & 37.936 & 2,940 \\
\hline 043939 & NWS & -119.783 & 37.961 & 1,180 \\
\hline 043369 & NWS & -119.140 & 37.752 & 2,734 \\
\hline 048380 & NWS & -119.634 & 37.507 & 1,566 \\
\hline 045400 & NWS & -119.856 & 37.881 & 1,375 \\
\hline $19113 \mathrm{~s}$ & SNOTEL & -119.233 & 38.067 & 2,879 \\
\hline 040943 & NWS & -119.014 & 38.212 & 2,551 \\
\hline 041878 & NWS & -119.705 & 37.250 & 680 \\
\hline 045280 & NWS & -118.962 & 37.648 & 2,379 \\
\hline 041072 & NWS & -119.229 & 38.257 & 1,972 \\
\hline 045352 & NWS & -119.986 & 37.495 & 640 \\
\hline 041697 & NWS & -119.916 & 37.975 & 1,452 \\
\hline 043672 & NWS & -120.098 & 37.823 & 959 \\
\hline 044176 & NWS & -119.221 & 37.228 & 2,140 \\
\hline 040379 & NWS & -119.513 & 37.092 & 637 \\
\hline 040755 & NWS & -119.242 & 37.206 & 1,487 \\
\hline $19138 \mathrm{~s}$ & SNOTEL & -119.600 & 38.267 & 2,931 \\
\hline 048406 & NWS & -118.571 & 37.168 & 2,920 \\
\hline $19119 \mathrm{~s}$ & SNOTEL & -119.800 & 38.533 & 2,672 \\
\hline 046252 & NWS & -119.507 & 37.231 & 802 \\
\hline $19117 \mathrm{~s}$ & SNOTEL & -119.350 & 38.433 & 2,814 \\
\hline $19106 \mathrm{~s}$ & SNOTEL & -119.617 & 38.500 & 2,358 \\
\hline $19108 \mathrm{~s}$ & SNOTEL & -119.550 & 38.300 & 2,194 \\
\hline $19107 \mathrm{~s}$ & SNOTEL & -119.583 & 38.300 & 2,690 \\
\hline
\end{tabular}


Table 3-2. Number of missing days per water year for temperature and precipitation stations in and around the Merced River Basin.

[ID, identifier]

\begin{tabular}{|c|c|c|c|c|c|c|c|c|c|c|c|c|c|c|c|c|c|c|c|}
\hline $\begin{array}{l}\text { Station } \\
\text { ID }\end{array}$ & 1990 & 1991 & 1992 & 1993 & 1994 & 1995 & 1996 & 1997 & 1998 & 1999 & 2000 & 2001 & 2002 & 2003 & 2004 & 2005 & 2006 & 2007 & 2008 \\
\hline \multicolumn{20}{|c|}{ Number of missing daily temperature values per year } \\
\hline 049855 & 29 & 54 & 42 & 80 & 155 & 287 & 214 & 203 & 230 & 59 & 53 & 54 & 30 & 25 & 80 & 137 & 131 & 226 & 257 \\
\hline 044881 & 41 & 51 & 32 & 76 & 21 & 35 & 18 & 55 & 66 & 62 & 44 & 26 & 30 & 16 & 78 & 27 & 26 & 48 & 17 \\
\hline 042756 & 365 & 365 & 366 & 365 & 365 & 365 & 366 & 365 & 365 & 365 & 366 & 365 & 365 & 365 & 366 & 365 & 365 & 365 & 366 \\
\hline 043939 & 25 & 20 & 24 & 27 & 75 & 27 & 11 & 49 & 16 & 37 & 14 & 35 & 24 & 10 & 25 & 4 & 5 & 24 & 23 \\
\hline 043369 & 365 & 365 & 366 & 365 & 365 & 365 & 366 & 365 & 365 & 365 & 366 & 365 & 365 & 365 & 366 & 365 & 365 & 365 & 366 \\
\hline 048380 & 88 & 102 & 175 & 321 & 292 & 298 & 256 & 254 & 289 & 276 & 257 & 315 & 19 & 10 & 31 & 12 & 68 & 106 & 24 \\
\hline 045400 & 365 & 365 & 366 & 365 & 365 & 365 & 366 & 365 & 365 & 365 & 366 & 365 & 365 & 365 & 366 & 365 & 365 & 365 & 366 \\
\hline $19113 \mathrm{~s}$ & 78 & 122 & 29 & 56 & 47 & 30 & 37 & 30 & 41 & 33 & 19 & 50 & 39 & 37 & 41 & 31 & 31 & 32 & 33 \\
\hline 040943 & 29 & 30 & 18 & 27 & 33 & 17 & 18 & 26 & 54 & 23 & 12 & 32 & 26 & 13 & 14 & 40 & 27 & 78 & 33 \\
\hline 041878 & 365 & 365 & 366 & 365 & 365 & 365 & 366 & 365 & 365 & 365 & 366 & 365 & 365 & 365 & 366 & 365 & 365 & 365 & 366 \\
\hline 045280 & 365 & 365 & 366 & 338 & 81 & 35 & 25 & 65 & 76 & 48 & 52 & 79 & 35 & 25 & 43 & 26 & 52 & 55 & 84 \\
\hline 041072 & 34 & 23 & 31 & 24 & 28 & 24 & 29 & 56 & 74 & 81 & 66 & 64 & 17 & 66 & 225 & 365 & 127 & 82 & 73 \\
\hline 045352 & 365 & 365 & 366 & 365 & 365 & 365 & 366 & 365 & 365 & 365 & 366 & 365 & 365 & 365 & 366 & 365 & 365 & 365 & 366 \\
\hline 041697 & 24 & 20 & 7 & 17 & 16 & 6 & 39 & 7 & 6 & 7 & 4 & 9 & 17 & 1 & 4 & 12 & 7 & 7 & 12 \\
\hline 043672 & 365 & 365 & 366 & 365 & 365 & 365 & 366 & 365 & 365 & 365 & 366 & 365 & 365 & 365 & 366 & 365 & 365 & 365 & 366 \\
\hline 044176 & 41 & 5 & 95 & 7 & 1 & 95 & 47 & 1 & 6 & 3 & 30 & 17 & 12 & 200 & 52 & 34 & 21 & 44 & 49 \\
\hline 040379 & 26 & 15 & 42 & 5 & 7 & 3 & 11 & 11 & 11 & 11 & 7 & 11 & 8 & 15 & 12 & 9 & 3 & 5 & 7 \\
\hline 040755 & 365 & 365 & 366 & 365 & 365 & 365 & 366 & 365 & 365 & 31 & 6 & 13 & 2 & 17 & 14 & 6 & 4 & 36 & 31 \\
\hline $19138 \mathrm{~s}$ & 45 & 47 & 129 & 54 & 55 & 51 & 48 & 38 & 55 & 43 & 40 & 66 & 50 & 48 & 57 & 36 & 57 & 43 & 43 \\
\hline 048406 & 365 & 365 & 366 & 365 & 365 & 365 & 366 & 365 & 365 & 365 & 366 & 365 & 365 & 365 & 366 & 365 & 365 & 365 & 366 \\
\hline $19119 \mathrm{~s}$ & 43 & 41 & 39 & 88 & 63 & 50 & 50 & 41 & 61 & 45 & 63 & 42 & 29 & 24 & 26 & 17 & 36 & 28 & 38 \\
\hline 046252 & 38 & 48 & 78 & 44 & 60 & 70 & 78 & 82 & 72 & 126 & 50 & 54 & 75 & 21 & 72 & 68 & 124 & 133 & 155 \\
\hline $19117 \mathrm{~s}$ & 32 & 27 & 21 & 41 & 41 & 35 & 34 & 28 & 40 & 33 & 26 & 52 & 40 & 26 & 34 & 18 & 33 & 31 & 40 \\
\hline $19106 \mathrm{~s}$ & 68 & 40 & 36 & 69 & 133 & 36 & 21 & 25 & 31 & 42 & 12 & 28 & 21 & 9 & 11 & 6 & 20 & 19 & 24 \\
\hline $19108 \mathrm{~s}$ & 20 & 9 & 7 & 25 & 23 & 5 & 11 & 11 & 9 & 7 & 1 & 18 & 22 & 7 & 6 & 13 & 21 & 12 & 12 \\
\hline $19107 \mathrm{~s}$ & 106 & 44 & 28 & 62 & 63 & 43 & 41 & 33 & 60 & 32 & 26 & 56 & 39 & 37 & 84 & 15 & 32 & 30 & 31 \\
\hline
\end{tabular}


[ID, identifier]

\begin{tabular}{|c|c|c|c|c|c|c|c|c|c|c|c|c|c|c|c|c|c|c|c|}
\hline $\begin{array}{l}\text { Station } \\
\text { ID }\end{array}$ & 1990 & 1991 & 1992 & 1993 & 1994 & 1995 & 1996 & 1997 & 1998 & 1999 & 2000 & 2001 & 2002 & 2003 & 2004 & 2005 & 2006 & 2007 & 2008 \\
\hline \multicolumn{20}{|c|}{ Number of missing daily precipitation values per year } \\
\hline 049855 & 305 & 302 & 303 & 238 & 320 & 229 & 294 & 159 & 3 & 0 & 160 & 153 & 310 & 275 & 225 & 227 & 220 & 213 & 257 \\
\hline 044881 & 208 & 272 & 264 & 257 & 274 & 279 & 222 & 271 & 303 & 326 & 270 & 299 & 300 & 267 & 287 & 264 & 240 & 291 & 157 \\
\hline 042756 & 9 & 1 & 0 & 31 & 0 & 0 & 29 & 0 & 0 & 0 & 93 & 60 & 0 & 31 & 30 & 334 & 365 & 365 & 366 \\
\hline 043939 & 19 & 3 & 2 & 2 & 31 & 117 & 2 & 67 & 2 & 0 & 3 & 4 & 1 & 0 & 2 & 1 & 22 & 2 & 0 \\
\hline 043369 & 0 & 0 & 31 & 24 & 0 & 0 & 29 & 0 & 0 & 154 & 53 & 31 & 61 & 92 & 142 & 365 & 365 & 365 & 366 \\
\hline 048380 & 297 & 304 & 325 & 346 & 348 & 354 & 340 & 252 & 21 & 2 & 55 & 170 & 322 & 303 & 326 & 257 & 117 & 130 & 25 \\
\hline 045400 & 303 & 247 & 254 & 254 & 295 & 322 & 245 & 297 & 225 & 281 & 266 & 286 & 306 & 269 & 294 & 236 & 232 & 274 & 245 \\
\hline $19113 \mathrm{~s}$ & 1 & 1 & 1 & 1 & 1 & 1 & 1 & 1 & 1 & 1 & 1 & 1 & 1 & 1 & 1 & 1 & 1 & 1 & 1 \\
\hline 040943 & 271 & 268 & 286 & 299 & 274 & 258 & 85 & 168 & 228 & 289 & 288 & 287 & 311 & 287 & 298 & 303 & 268 & 299 & 282 \\
\hline 041878 & 4 & 0 & 17 & 7 & 38 & 18 & 220 & 275 & 179 & 184 & 85 & 98 & 272 & 236 & 327 & 282 & 263 & 251 & 366 \\
\hline 045280 & 365 & 365 & 366 & 365 & 240 & 292 & 72 & 154 & 239 & 284 & 307 & 294 & 303 & 297 & 312 & 293 & 280 & 311 & 310 \\
\hline 041072 & 257 & 290 & 288 & 303 & 325 & 325 & 229 & 259 & 304 & 345 & 323 & 248 & 317 & 300 & 339 & 365 & 226 & 194 & 66 \\
\hline 045352 & 230 & 292 & 334 & 365 & 365 & 304 & 305 & 213 & 69 & 31 & 57 & 76 & 359 & 302 & 281 & 252 & 329 & 365 & 366 \\
\hline 041697 & 37 & 0 & 3 & 4 & 3 & 17 & 33 & 0 & 1 & 1 & 27 & 0 & 1 & 0 & 0 & 0 & 3 & 0 & 0 \\
\hline 043672 & 300 & 311 & 278 & 290 & 247 & 282 & 301 & 305 & 235 & 323 & 313 & 310 & 309 & 297 & 321 & 281 & 201 & 263 & 351 \\
\hline 044176 & 1 & 1 & 90 & 0 & 11 & 91 & 31 & 20 & 0 & 52 & 49 & 0 & 0 & 7 & 0 & 0 & 0 & 30 & 30 \\
\hline 040379 & 323 & 317 & 324 & 301 & 294 & 226 & 296 & 314 & 244 & 281 & 276 & 240 & 322 & 302 & 322 & 297 & 264 & 233 & 123 \\
\hline 040755 & 365 & 365 & 366 & 365 & 365 & 365 & 366 & 365 & 365 & 110 & 23 & 0 & 0 & 7 & 0 & 0 & 0 & 30 & 30 \\
\hline $19138 \mathrm{~s}$ & 1 & 1 & 1 & 1 & 1 & 1 & 1 & 1 & 1 & 1 & 1 & 1 & 1 & 1 & 1 & 1 & 1 & 1 & 1 \\
\hline 048406 & 0 & 0 & 1 & 29 & 0 & 0 & 28 & 0 & 0 & 0 & 50 & 36 & 38 & 1 & 314 & 365 & 365 & 365 & 366 \\
\hline $19119 \mathrm{~s}$ & 1 & 1 & 1 & 1 & 1 & 1 & 1 & 1 & 1 & 1 & 1 & 1 & 1 & 1 & 1 & 1 & 1 & 1 & 1 \\
\hline 046252 & 267 & 259 & 248 & 249 & 249 & 251 & 262 & 259 & 154 & 252 & 172 & 43 & 79 & 137 & 307 & 68 & 88 & 96 & 134 \\
\hline $19117 \mathrm{~s}$ & 1 & 1 & 1 & 1 & 1 & 1 & 1 & 1 & 1 & 1 & 1 & 1 & 1 & 1 & 1 & 1 & 1 & 1 & 1 \\
\hline $19106 \mathrm{~s}$ & 1 & 1 & 1 & 1 & 1 & 1 & 1 & 1 & 1 & 1 & 1 & 1 & 1 & 1 & 1 & 1 & 1 & 1 & 1 \\
\hline $19108 \mathrm{~s}$ & 1 & 1 & 1 & 1 & 1 & 1 & 1 & 1 & 1 & 1 & 1 & 1 & 1 & 1 & 1 & 1 & 1 & 1 & 1 \\
\hline $19107 \mathrm{~s}$ & 1 & 1 & 1 & 1 & 1 & 1 & 1 & 1 & 1 & 1 & 1 & 1 & 1 & 1 & 1 & 1 & 1 & 1 & 1 \\
\hline
\end{tabular}


The Parameter File was assembled for the Merced River watershed application with the parameters required by the modules listed in table 3-3 (see Appendix 1 for detailed descriptions of the modules used in this example).

Table 3-3. Modules used in the Precipitation-Runoff Modeling System Merced River application in the order they are called.

\begin{tabular}{cc}
\hline Module name \\
basin \\
soltab \\
obs \\
ide_dist or xyz_dist \\
ddsolrad \\
transp_tindex \\
potet_jh \\
intcp \\
snowcomp \\
srunoff_smidx \\
soilzone \\
gwflow \\
strmflow \\
basin_sum
\end{tabular}

\section{Hydrologic Response Unit Delineation}

For this application, hydrologic response unit (HRU) delineation, characterization, and parameterization were done by using the GIS Weasel (Viger and Leavesley, 2007). The HRUs were delineated by: (1) subdividing the watershed into two flow planes for each channel, (2) subdividing the watershed by using three equal-area elevation bands, and (3) intersecting the flowplane map with the elevation-band map. This process resulted in 90 HRUs for the Merced River application.

\section{Climate Distribution}

This application compares the xyz_dist and ide_dist modules for distribution of daily values of precipitation, maximum temperature, and minimum temperature to each HRE. Significant geographic factors affecting the spatial distribution of precipitation and temperature distributions within a watershed are longitude (x), latitude (y), and elevation (z). The xyz dist and the ide dist modules were developed to account for these geographic factors. The xyz dist module uses predetermined monthly regional relations between the given climate variable and $\mathrm{x}, \mathrm{y}$, and $\mathrm{z}$, whereas the ide dist module (Inverse Distance-Elevation) uses an $\mathrm{x}, \mathrm{y}$, and $\mathrm{z}$ relation on the basis of the data available for a given day. Detailed descriptions of both modules and associated parameters can be found in Appendix 1.

\section{xyz_dist}

The xyz_dist module uses a multiple linear regression (MLR) method to distribute daily measured precipitation and maximum and minimum temperature data from a group of stations (a single daily mean value) to each HRU in a watershed on the basis of the $\mathrm{x}, \mathrm{y}$, and $\mathrm{z}$ values of the HRU. To account for seasonal climate variations, an MLR equation was developed for each month for each of the dependent variables of precipitation and maximum and minimum temperature by using the independent variables of $\mathrm{x}, \mathrm{y}$, and $\mathrm{z}$ from a set of climate stations that fell within and around the Merced River watershed (listed in table 3-1). These equations were developed outside of the PRMS simulation.

Starting with an initial pool of 26 climate stations, all combinations of $\mathrm{x}, \mathrm{y}$, and $\mathrm{z}$ were tested in each monthly MLR by eliminating some stations. An adjusted coefficient of determination $\left(\mathrm{R}^{2}\right)$ value (a modification of $\mathrm{R}^{2}$ that adjusts for the number of explanatory terms in a model; see Helsel and Hirsch, 2002) was calculated for each combination of x, y, and z, and the MLRs associated with the highest adjusted $\mathrm{R}^{2}$ were chosen. Table 3-4 shows the "slope" values determined for each dependent variable in the Merced River watershed for the MLR associated with the highest adjusted $\mathrm{R}^{2}$. Note that a station was not used in the MLR if it had greater than 20 percent missing record over the period of record (see table 3-2). 


\section{ide_dist}

The ide_dist module uses a combination of inverse distance and elevation weighting for interpolating station-based precipitation and maximum and minimum temperature data to each HRU. For each HRU, the three closest stations with nonmissing data were used.

Table 3-4. Multiple linear regression coefficients for the Merced watershed.

[R2, coefficient of determination; $\mathrm{x}, \mathrm{x}$-coordinate direction; $\mathrm{y}, \mathrm{y}$-coordinate direction; $\mathrm{z}, \mathrm{z}$-coordinate direction]

\begin{tabular}{|c|c|c|c|c|}
\hline Month & Adjusted $\mathrm{R}^{2}$ & max_lapse(x) & max_lapse(y) & max_lapse(z) \\
\hline \multicolumn{5}{|c|}{ Maximum temperature } \\
\hline January & 0.854780 & 0.000000 & 0.000000 & -0.344710 \\
\hline Feburary & 0.944355 & 0.000000 & 0.000000 & -0.465483 \\
\hline March & 0.964202 & 0.000000 & 0.069704 & -0.585910 \\
\hline April & 0.963717 & 0.000000 & 0.000000 & -0.643905 \\
\hline May & 0.929923 & 0.000000 & 0.000000 & -0.717476 \\
\hline June & 0.998897 & -0.361945 & -0.374187 & 0.000000 \\
\hline July & 0.905855 & 0.000000 & 0.110676 & -0.794772 \\
\hline August & 0.902110 & 0.000000 & 0.000000 & -0.708938 \\
\hline September & 0.957635 & 0.000000 & 0.000000 & -0.743576 \\
\hline October & 0.946124 & 0.000000 & 0.000000 & -0.651466 \\
\hline November & 0.926118 & 0.000000 & 0.000000 & -0.522494 \\
\hline December & 0.879448 & 0.000000 & -0.075288 & -0.318254 \\
\hline \multicolumn{5}{|c|}{ Minimum temperature } \\
\hline January & 0.910925 & -0.820891 & -0.223762 & 0.000000 \\
\hline Feburary & 0.943623 & -0.502175 & -0.192010 & -0.379683 \\
\hline March & 0.969557 & -0.412762 & -0.138875 & -0.484279 \\
\hline April & 0.968961 & 0.000000 & 0.000000 & -0.793531 \\
\hline May & 0.976760 & 0.000000 & 0.000000 & -0.837777 \\
\hline June & 0.980469 & 0.000000 & 0.000000 & -0.946149 \\
\hline July & 0.998724 & -0.413322 & -0.156225 & -0.572160 \\
\hline August & 0.999214 & -0.485418 & -0.221267 & -0.484273 \\
\hline September & 0.988945 & -0.585525 & -0.253950 & -0.397008 \\
\hline October & 0.968533 & -0.655606 & -0.239455 & -0.332201 \\
\hline November & 0.944882 & -0.862145 & -0.280742 & 0.000000 \\
\hline December & 0.927056 & -0.803910 & -0.259120 & 0.000000 \\
\hline \multicolumn{5}{|c|}{ Precipitation } \\
\hline January & 0.803708 & -2.186436 & -0.455580 & 1.161595 \\
\hline Feburary & 0.754866 & -1.792950 & -0.475403 & 1.085278 \\
\hline March & 0.694469 & -0.963488 & -0.117560 & 0.575561 \\
\hline April & 0.724228 & -0.899676 & -0.178538 & 0.576006 \\
\hline May & 0.610259 & -0.566289 & 0.000000 & 0.200880 \\
\hline June & 0.150563 & -0.077511 & 0.000000 & 0.045962 \\
\hline July & 0.412416 & 0.108589 & 0.000000 & 0.000000 \\
\hline August & 0.729505 & 0.089965 & 0.041431 & 0.000000 \\
\hline September & 0.515176 & -0.103636 & 0.000000 & 0.134836 \\
\hline October & 0.771054 & -0.480913 & -0.112650 & 0.254883 \\
\hline November & 0.735599 & -1.040447 & 0.000000 & 0.591963 \\
\hline December & 0.672498 & -1.434026 & 0.000000 & 0.788680 \\
\hline
\end{tabular}




\section{PRMS Calibration}

A step-wise, multiple-objective calibration scheme (Luca; Hay and Umemoto, 2007) was used to calibrate PRMS-IV for the Merced River application. Luca uses the Shuffled Complex Evolution (SCE) technique (Duan and others, 1992; 1993; and 1994) optimization algorithm, which has been used successfully by a number of researchers (Yapo and others, 1996; Kuczera, 1997; Hogue and others, 2000; and Madsen, 2003). The SCE method selects a population of points distributed randomly throughout the parameter space. The population is partitioned into several complexes. Each of these complexes "evolves" by using the downhill simplex algorithm. The population is periodically "shuffled" to form new complexes so that the information gained by the previous complexes is shared. The evolution and shuffling steps repeat until prescribed convergence criteria are satisfied.

Figure 3-1 illustrates the step-wise, multiple-objective calibration scheme used for this application. Table 3-5 lists the calibration step and associated calibration data sets, objective function, model parameters calibrated in each step, minimum and maximum parameter value range, and calibration description. For each of the four calibration steps, the following calibration data sets are derived from measured data to compare with PRMS-IV outputs: (1) mean monthly solar radiation, (2) mean monthly potential evapotranspiration, (3) streamflow volumes (annual mean, mean monthly, and monthly mean), and (4) streamflow timing (daily and monthly mean).

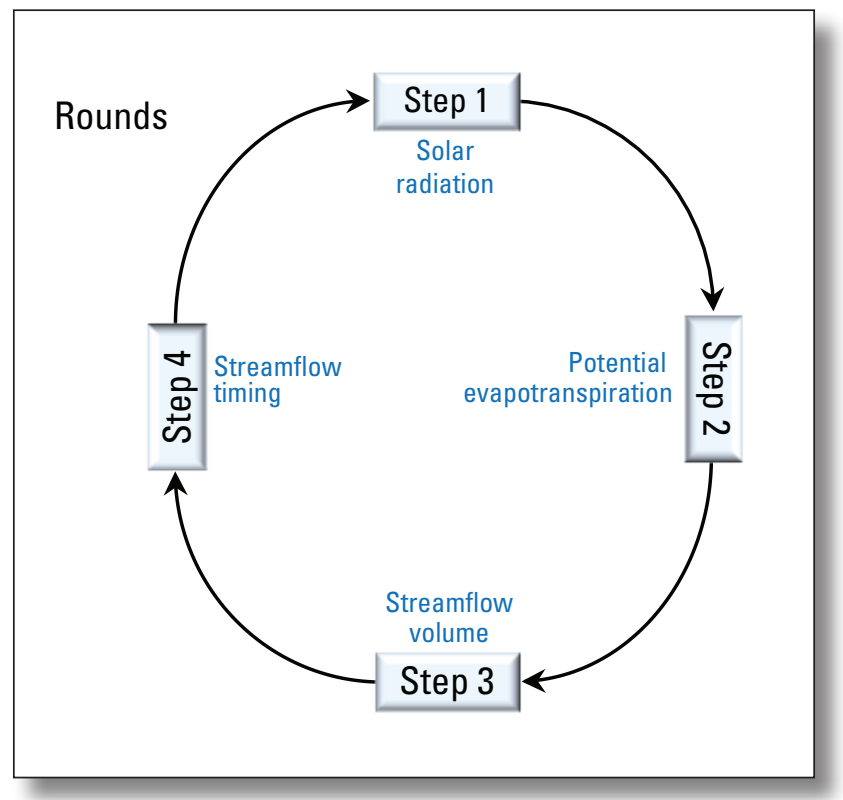

Figure 3-1. Multi-objective, step-wise calibration procedure for a Precipitation-Runoff Modeling System, version 4 (PRMS-IV) application. 
Table 3-5. Parameters calibrated in each step of the calibration process for a Precipitation-Runoff Modeling System, version 4 (PRMS-IV) application of the Merced River Basin.

\begin{tabular}{|c|c|c|c|c|c|}
\hline $\begin{array}{l}\text { Data } \\
\text { sets }\end{array}$ & $\begin{array}{c}\text { Objective } \\
\text { function }\end{array}$ & Parameter & $\begin{array}{l}\text { Parameter } \\
\text { range }\end{array}$ & $\begin{array}{c}\text { Parameter } \\
\text { units }\end{array}$ & $\begin{array}{l}\text { Calibration } \\
\text { description }\end{array}$ \\
\hline \multicolumn{6}{|c|}{ Calibration step 1: Solar Radiation } \\
\hline \multirow{2}{*}{ Mean Monthly } & \multirow{2}{*}{$\begin{array}{l}\text { Sum of absolute } \\
\text { difference in } \\
\text { measured and } \\
\text { simulated }\end{array}$} & dday_slope & 0.2 to 0.9 & dday/temp_units & Calibrate the mean \\
\hline & & tmax_index & 50 to 90 & temp_units & Calibrate the mean \\
\hline Mean Monthly & $\begin{array}{l}\text { Sum of absolute } \\
\text { difference in } \\
\text { measured and } \\
\text { simulated }\end{array}$ & jh_coef & 0.005 to 0.09 & per degrees Fahrenheit & Calibrate individual values \\
\hline \multicolumn{6}{|c|}{ Calibration step 3: Streamflow (volume) } \\
\hline $\begin{array}{l}\text { Annual Mean } \\
\text { Mean Monthly } \\
\text { Monthly Mean }\end{array}$ & $\begin{array}{l}\text { Normalized root } \\
\text { mean square error }\end{array}$ & psta_freq_nuse 1 & 0 or 1 & decimal fraction & Parameters are binary \\
\hline \multicolumn{6}{|c|}{ Calibration step 4: Streamflow (timing) } \\
\hline \multirow{11}{*}{$\begin{array}{l}\text { Daily } \\
\text { Monthy Mean }\end{array}$} & \multirow{11}{*}{$\begin{array}{l}\text { Normalized root } \\
\text { mean square error }\end{array}$} & adjmix_rain & 0 to 1 & decimal fraction & Calibrate the mean \\
\hline & & cecn_coef & 0 to 20 & calories per degree Celsius $>0$ & Calibrate the mean \\
\hline & & emis_noppt & 0.757 to 1 & decimal fraction & Calibrate the mean \\
\hline & & fastcoef_lin & 0.0001 to 1 & fraction/day & Calibrate the mean \\
\hline & & fastcoef_sq & 0.00001 to 1 & none & Calibrate the mean \\
\hline & & freeh2o_cap & 0.01 to 0.2 & inches & Calibrate the mean \\
\hline & & soil_rechr_max & 0 to 20 & inches & Calibrate the mean \\
\hline & & soil2gw_max & 0.0 to 0.5 & inches & Calibrate the mean \\
\hline & & tmax_allrain & 50 to 75 & temp_units & Calibrate the mean \\
\hline & & tmax_allsnow & 30 to 35 & temp_units & Calibrate the mean \\
\hline & & tsta_nuse2 & 0 or 1 & none & Parameters are binary \\
\hline
\end{tabular}

${ }^{1}$ Parameter tsta_freq_nuse only calibrated for module xyz_dist, not calibrated for module ide_dist.

${ }^{2} \mathrm{~A}$ minimum of one station must be selected for parameters psta_nuse and tsta_nuse.

To begin the calibration procedure, an initial Parameter File containing all PRMS-IV parameters was assembled. Parameter values characterizing land-surface processes were computed from GIS data by using the GIS Weasel program. All other parameters were set to their default values. Step by step, the parameters designated in table 3-5 were calibrated. Calibrated parameter values are used in subsequent steps. Completion of the four calibration steps constitutes a round. This process was repeated for six rounds. The following section describes the four calibration steps in detail and the optimization algorithm. 


\section{Calibration Step 1-Solar Radiation}

The calibration data set used for the first step was mean monthly solar radiation values for the Merced River watershed. These "measured" mean monthly solar radiation values were pre-calculated (outside of the PRMS simulation) as per Hay and others (2006). In this application, daily solar radiation values were simulated by the ddsol rad module from computed air temperature. Three parameters are calibrated (table 3-5).

The objective function used to calibrate the mean monthly solar radiation values was the absolute difference and was calculated as follows:

$$
O F_{S R}=\sum_{m=1}^{12} \mathrm{abs}\left[\frac{\left(M S D_{m}-S I M_{m}\right)}{M S D_{m}}\right],
$$

where
$O F_{S R} \quad$ is the objective function,
$m \quad$ is the month, and
MSD and SIM are the mean monthly measured and simulated solar radiation values, respectively. The 'abs' function refers to the absolute value.

\section{Calibration Step 2-Potential Evapotranspiration}

The calibration data set used for the second step was "measured" mean monthly potential evapotranspiration (PET) values for the Merced River watershed. The watershed mean monthly PET values were derived from the National Weather Service freewater evaporation atlas (Farnsworth and others, 1982). Daily estimates of PET were simulated by the potet_jh module by using a procedure developed by Jensen and Haise (1963). One parameter is calibrated (table 3-5). The objective function used to calibrate PET was the same one used to calibrate solar radiation (equation 3-1).

\section{Calibration Step 3-Streamflow Volume}

The calibration data set used for the third step was measured streamflow from USGS gaging station 11266500. Four parameters were calibrated when using the xyz_dist module, while two were calibrated when using the ide_dist module (table 3-5).

The streamflow volume objective function $\left(\mathrm{OF}_{\mathrm{SV}}\right)$ is the sum of three objective functions: $(1)$ annual mean water volumes $\left(\mathrm{OF}_{\text {ann }}\right),(2)$ mean monthly water volumes $\left(\mathrm{OF}_{\mathrm{mnmth}}\right)$, and (3) monthly mean water volumes $\left(\mathrm{OF}_{\mathrm{mthmn}}\right)$ according to:

$$
\mathrm{O} F_{S V}=O F_{a n n}+O F_{m n m t n}+O F_{m t h m n}
$$

where

$$
\begin{gathered}
\mathrm{OF}_{\text {ann, }} \mathrm{OF}_{\text {mnth }} \text {, and } \mathrm{OF}_{\text {mthmn }} \quad \text { are computed by using the normalize root mean square error (NRMSE) according to: } \\
\qquad N R M S E=\left(\sum_{n=1}^{\text {nstep }}(\operatorname{MSD}(n)-\operatorname{SIM}(n))^{2} / \sum_{n=1}^{n \text { nstep }}(M S D(n)-M N)^{2}\right)^{1 / 2}
\end{gathered}
$$

where

$\begin{aligned} \text { nstep } & \text { is the total number of time steps, and } \\ \text { MSD, SIM, and MN } & \text { are the measured, simulated, and mean values associated with } \mathrm{OF}_{\text {ann, }}, \mathrm{OF}_{\text {mnnth }}, \text { or } \mathrm{OF}_{\text {mthmn }}, \text { respectively. }\end{aligned}$




\section{Calibration Step 4-Streamflow Timing}

The calibration data set used for the fourth step was measured streamflow from USGS gaging station 11266500 . The parameters used for calibration are shown in table 3-5.

The streamflow timing objective function $\left(\mathrm{OF}_{\mathrm{ST}}\right)$ is the sum of the two objective functions: (1) daily streamflow $\left(\mathrm{OF}_{\text {daily }}\right)$ and (2) monthly mean streamflow $\left(\mathrm{OF}_{\mathrm{mthmn}}\right)$ and is calculated according to:

$$
O F_{S T}=O F_{d a i l y}+O F_{m t h m n}
$$

Both $\mathrm{OF}_{\text {daily }}$ and $\mathrm{OF}_{\text {mthmn }}$ were calculated by using all daily measured flow values for the period of record or for each month of interest, respectively; and were computed by using the NRMSE (equation 3-3).

\section{Calibration Results}

For this application, a split sample test was used for calibration and evaluation. Ten water years (1991-2000) were chosen for model calibration. Eight water years (2001-08) were chosen for model evaluation. Results from the sixth round of the stepwise calibration procedure are presented.

\section{Solar Radiation}

Figure 3-2 shows measured (gray line), calibrated (red line), and evaluated (blue line) values of mean solar radiation by month. The results produced by the xyz_dist and ide_dist modules are similar: calibrated solar radiation values are almost identical to those shown for measured and evaluated solar radiation values. Evaluated solar radiation values show close agreement with measured values except for the months of May and June.
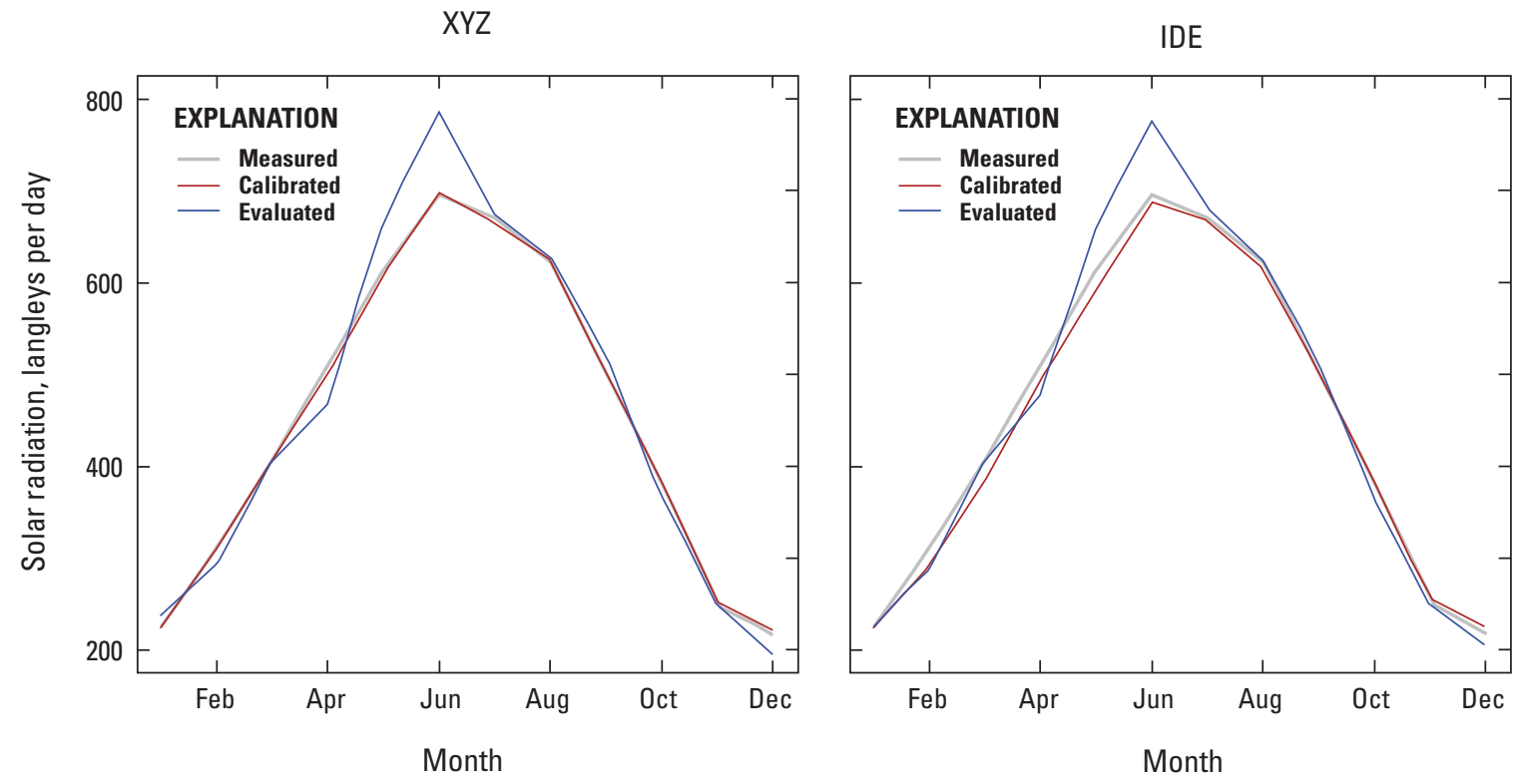

Figure 3-2. Measured, calibrated, and evaluated watershed mean-monthly solar radiation for the calibration and evaluation periods. (XYZ, xyz_dist module; IDE, ide_dist module) 


\section{Potential Evapotranspiration}

Figure 3-3 shows measured (gray line), calibrated (red line), and evaluated (blue line) PET values by month. The results produced by the xyz_dist and ide_dist modules are similar: calibrated PET values are almost identical to those shown for measured and evaluated PET values. Evaluated PET values show close agreement with measured values except for the months of May, June, and July.

$\mathrm{XYZ}$

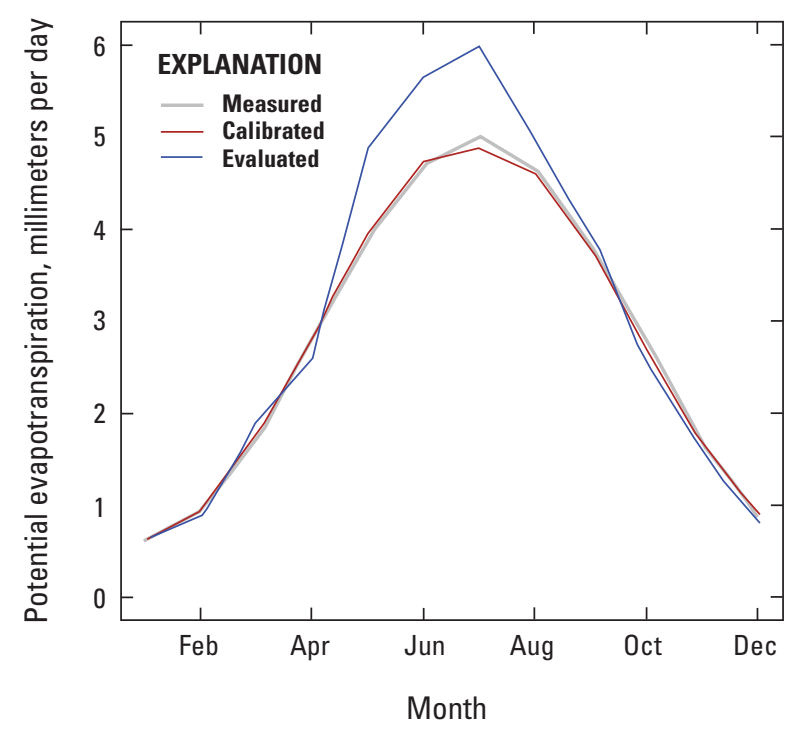

IDE

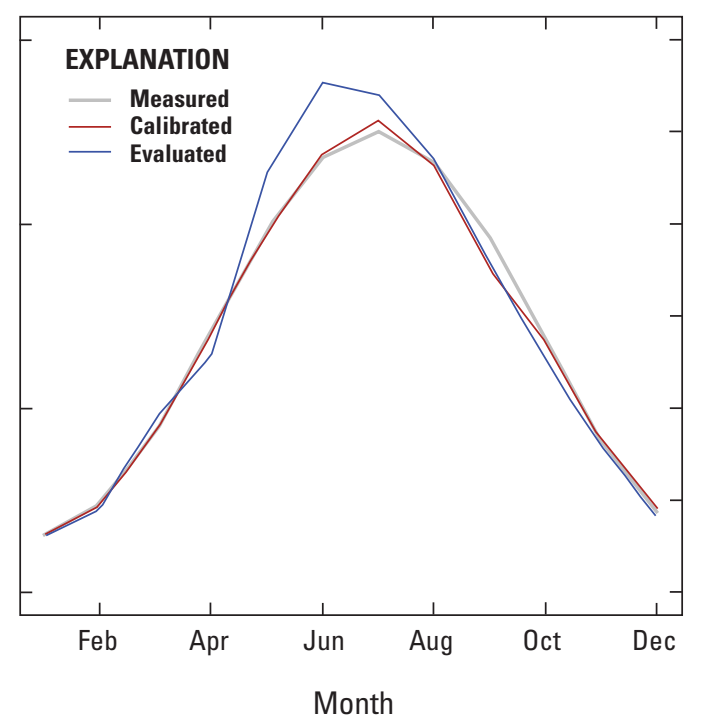

Figure 3-3. Measured, calibrated, and evaluated watershed mean-monthly potential evapotranspiration for the calibration and evaluation periods. (XYZ, xyz_dist module; IDE, ide_dist module)

\section{Streamflow Volume}

Figures 3-4, 3-5, and 3-6 show results produced by the xyz dist and ide dist modules for calibration of mean annual, mean monthly, and monthly mean streamflow, respectively. When evaluated on different temporal resolutions, the discrepancies in the results produced by the xyz_dist and ide_dist modules become more apparent. When streamflow is evaluated on a mean annual basis, the results from the xyz_dist module show close agreement to measured data for both calibration and evaluation periods. However, the results from the ide_dist module show less agreement (fig. 3-4). When streamflow is evaluated on a mean monthly basis, it is very apparent that the ide_dist module is not performing as well as the xyz_dist module in this application (fig. 3-5). A comparison of monthly mean measured versus simulated streamflow further show the differences between the results produced by the two modules (fig. 3-6). 
$X Y Z$

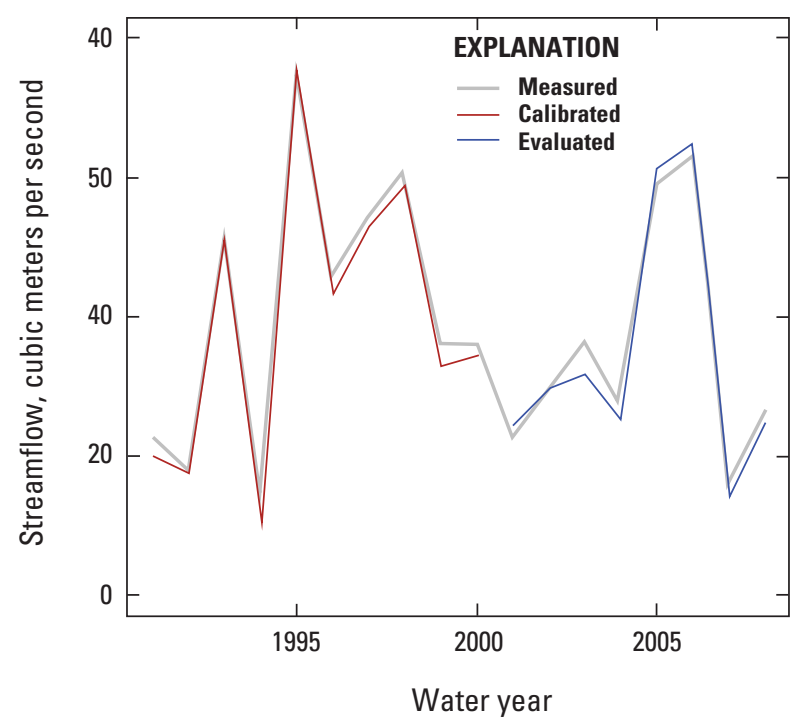

IDE

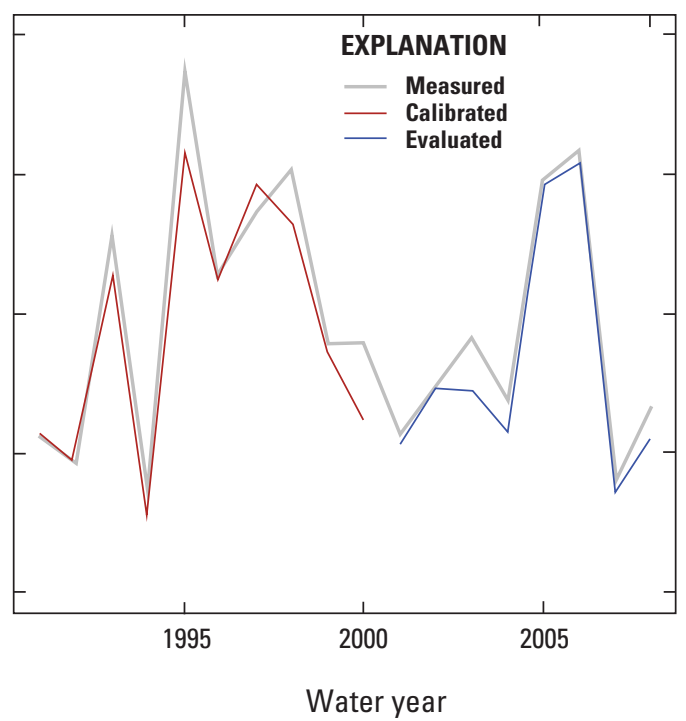

Figure 3-4. Measured, calibrated, and evaluated mean-annual streamflow for the calibration (red line) and evaluation periods. (XYZ, $x y z$ _dist module; IDE, ide_dist module)

$\mathrm{XYZ}$

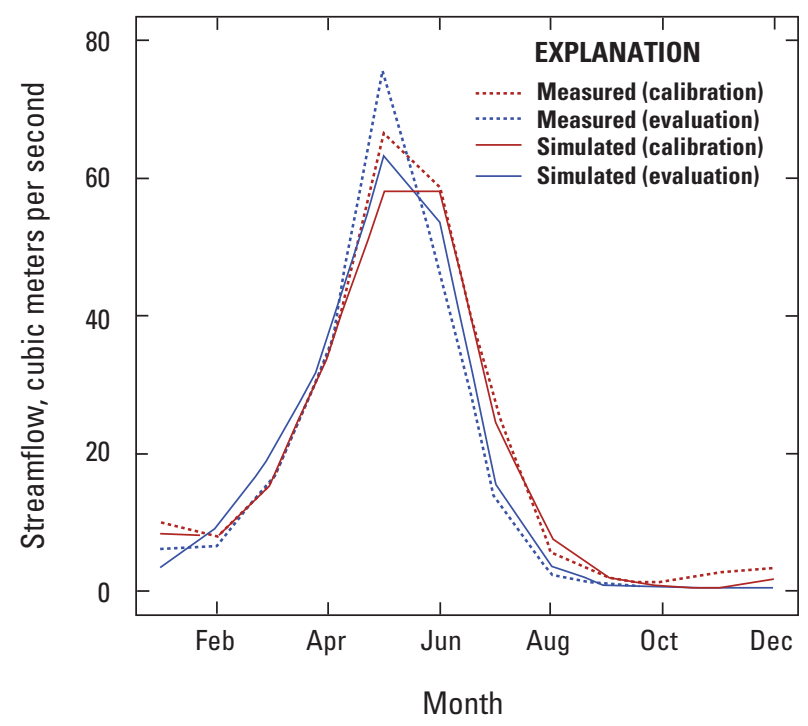

IDE

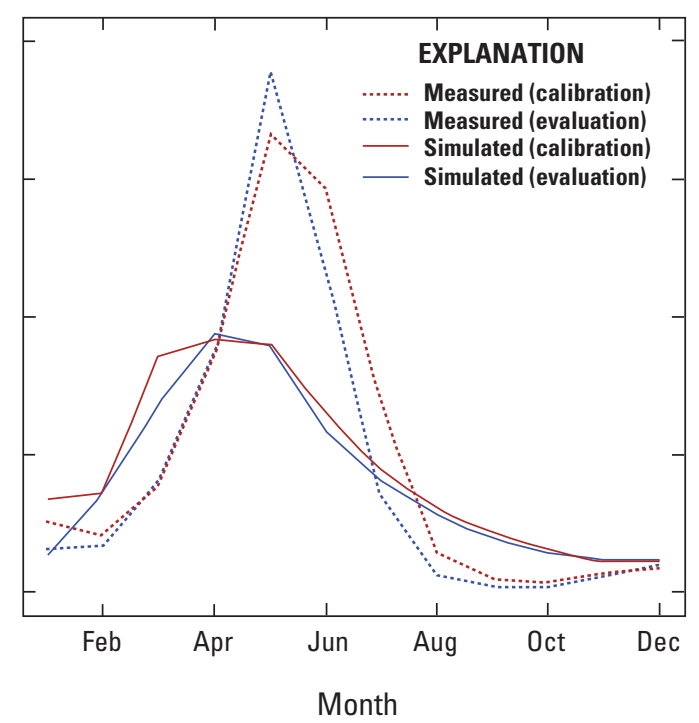

Figure 3-5. Measured and simulated mean-monthly streamflow for the calibration and evaluation periods. (XYZ, XYZ_dist module; IDE, ide_dist module) 
$\mathrm{XYZ}$

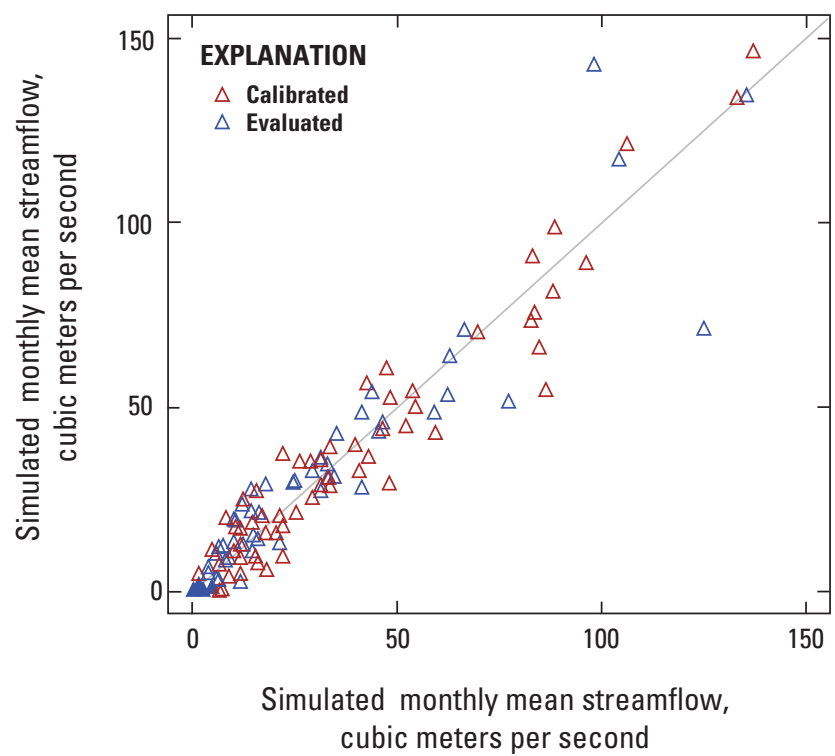

IDE

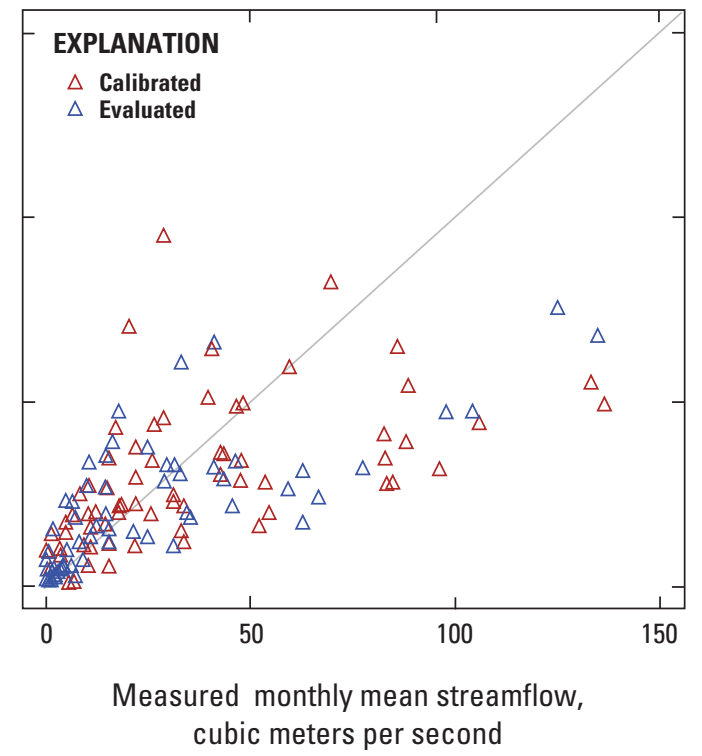

Figure 3-6. Measured versus simulated monthly mean streamflow for the calibration and evaluation periods. (XYZ, XYz_dist module; IDE, ide_dist module)

\section{Streamflow Timing}

Figures 3-7 and 3-8 show results produced by the xyz_dist and ide_dist modules, respectively, for daily time step streamflow. When streamflow is evaluated on a daily basis, both the Nash-Sutcliffe Goodness of Fit statistic by water year (Nash and Sutcliffe, 1970) and the daily streamflow hydrographs indicate that the xyz_dist module is performing better than the ide_dist module in this application.
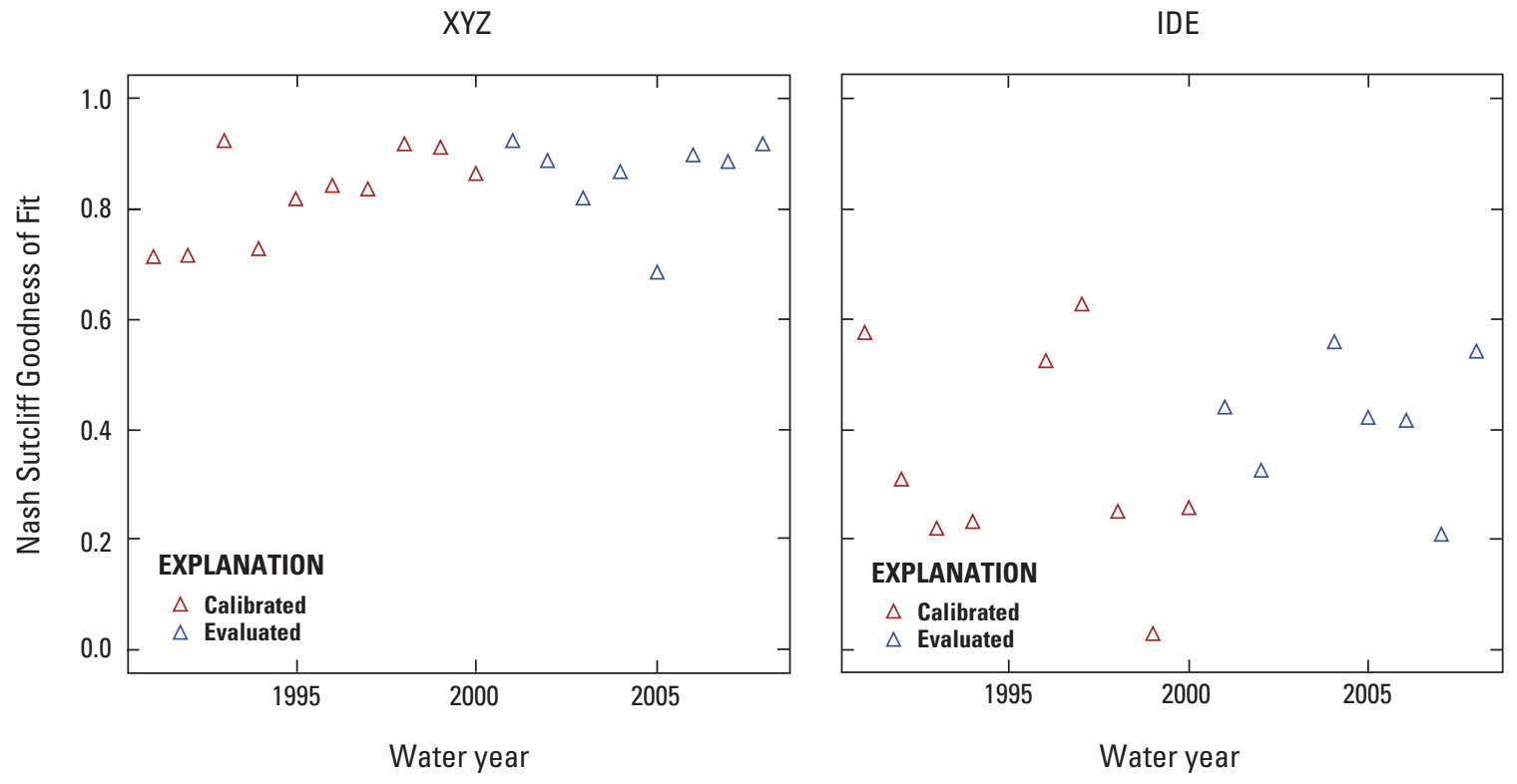

Figure 3-7. Annual Nash Sutcliffe goodness of fit values for daily flows for the calibration and evaluation periods. (XYZ, XYZ_dist module; IDE, ide_dist module) 

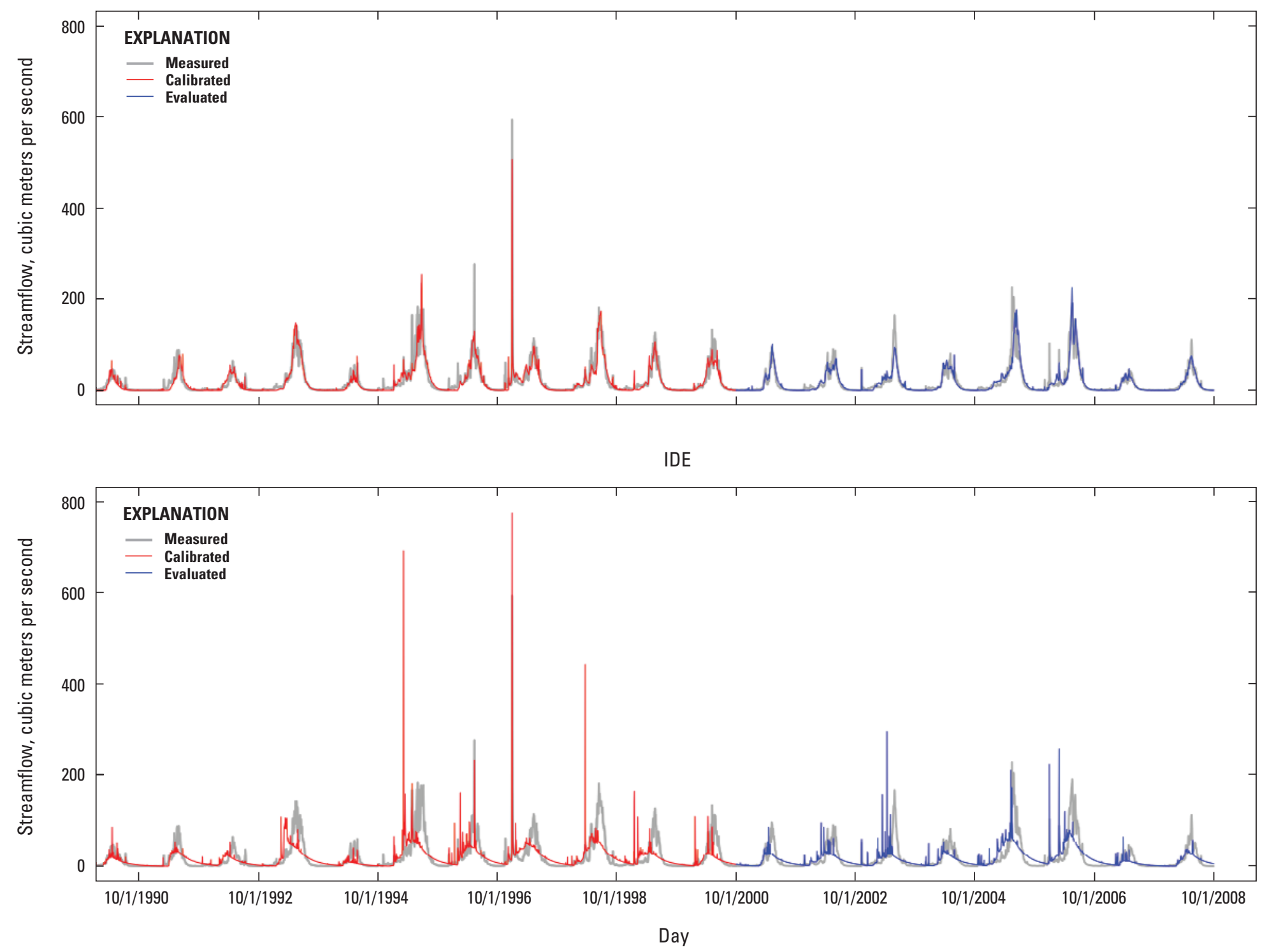

Figure 3-8. Measured and simulated daily streamflow for the calibration and evaluation periods. (XYZ, XYZ_dist module; IDE, ide_ dist module) 


\section{Discussion and Conclusion}

A comparison of climate-distribution techniques (xyz_dist and ide_dist) was used to emphasize the importance of the climate-distribution module choice when applying PRMS. This example used the snowmelt-dominated Merced River watershed in California. For this particular application, the xyz_dist module was found to give superior results compared to the ide_dist module. Both modules were able to reproduce the timing and volume of measured streamflow when evaluated on an annual basis. However, the differences between the modules became apparent when evaluated on a monthly and daily basis. This can be attributed primarily to the available climate data used in the distribution process (tables 3-1 and 3-2). It is probable that the data were not of a high enough density, temporally or spatially, to support the ide_dist module.

Simulations of snowmelt-dominated watersheds typically need accurate estimates of temperature to show the melting of the snowpack. The spatial and temporal coverage of the climate stations used for this Merced River watershed application was sparse. The algorithms used in the ide_dist module may not be appropriate under these conditions. In contrast, this application demonstrates that the algorithms used in the xyz_dist module can produce better results under these conditions. 


\section{References Cited}

Duan, Qingyun, Gupta, V.K., and Sorooshian, Soroosh, 1993, A shuffled complex evolution approach for effective and efficient global minimization: Journal of Optimization Theory and its Applications, v. 76, no. 3, p. 501-521.

Duan, Qingyun, Sorooshian, Soroosh, and Gupta, V.K., 1992, Effective and efficient global optimization for conceptual rainfall-runoff models: Water Resources Research, v. 28, no. 4 , p. $1,015-1,031$.

Duan, Qingyun, Sorooshian, Soroosh and Gupta, V.K., 1994, Optimal use of the SCE-UA global optimization method for calibrating basin models: Journal of Hydrology, v. 158, p. $265-284$.

Farnsworth, R.K., Thompson, E.S., and Peck, E.L., 1982, Evaporation atlas for the contiguous 48 United States: Washington D.C., U.S. Department of Commerce, NOAA Technical Report NWS 33.

Hay, L.E., Leavesley, G.H., Clark, M.P., Markstrom, S.L., Viger, R.J., and Umemoto, Makiko, 2006, Step-wise, multiple-objective calibration of a hydrologic model for a snowmelt-dominated basin: Journal of American Water Resources, v. 42, no. 4, p. 877-890.

Hay, L.E., and Umemoto, Makiko, 2007, Multiple-objective stepwise calibration using Luca: U.S. Geological Survey Open-File Report 2006-1323, 25 p., at http://pubs.usgs.gov/ of/2006/1323/.

Helsel, D.R., and Hirsch, R.M., 2002, Statistical methods in water resources: U.S. Geological Survey Techniques of Water-Resources Investigations, book 4, chap. A3, 522 p.

Hogue, T.S., Sorooshian, Soroosh, Gupta, H.V., Holz, Andrea, and Braatz, Dean, 2000, A multi-step automatic calibration scheme for river forecasting models: Journal of Hydrometeorology, v. 1, p. 524-542.
Jensen, M.E., and Haise, H.R., 1963, Estimating evapotranspiration from solar radiation: Proceedings of the American Society of Civil Engineers, Journal of Irrigation and Drainage, v. 89(IR4), p. 15-41.

Kuczera, G.A., 1997, Efficient subspace probabilistic parameter optimization for catchment models: Water Resources Research, v. 33, no. 1, p. 177-186.

Madsen, Henrik, 2003, Parameter estimation in distributed hydrological catchment modeling using automatic calibration with multiple objectives: Advances in Water Resources, v. 26, p. 205-216.

Nash, J.E., and Sutcliffe, J.V., 1970, River flow forecasting through conceptual models part I-A discussion of principles: Journal of Hydrology, v. 10, no. 3, p. 282-290.

Sorenson, S.K., 1982, Water-quality assessment of the Merced River, California: U.S. Geological Survey Open-File Report 82-450, 46 p., at http://pubs.er.usgs.gov/publication/ ofr 82450 .

Viger, R.J., and Leavesley, G.H., 2007, The GIS Weasel user's manual: U.S. Geological Survey Techniques and Methods, book 6, chap. B4, $201 \mathrm{p}$.

Ward-Garrison, C.D., Markstrom, S.L., and Hay, L.E., 2009, Downsizer-A graphical user interface-based application for browsing, acquiring, and formatting time-series data for hydrologic models: U.S. Geological Survey OpenFile Report 2009-1166, 27 p., at http://pubs.usgs.gov/ of/2009/1166/.

Yapo, P.O., Gupta, H.V., and Sorooshian, Soroosh, 1996, Automatic calibration of conceptual rainfall-runoff models - Sensitivity to calibration data: Journal of Hydrology, v. 181, p. 23-48. 


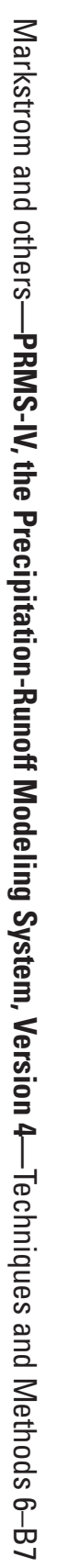

